\title{
National Register Eligibility Testing of 41MM340 and 41MM341, along Little River, Milam County, Texas
}

Richard B. Mahoney

Steve A. Tomka

Raba Kistner

Follow this and additional works at: https://scholarworks.sfasu.edu/ita

Part of the American Material Culture Commons, Archaeological Anthropology Commons, Environmental Studies Commons, Other American Studies Commons, Other Arts and Humanities Commons, Other History of Art, Architecture, and Archaeology Commons, and the United States History Commons

Tell us how this article helped you.

This Article is brought to you for free and open access by the Center for Regional Heritage Research at SFA ScholarWorks. It has been accepted for inclusion in Index of Texas Archaeology: Open Access Gray Literature from the Lone Star State by an authorized editor of SFA ScholarWorks. For more information, please contact cdsscholarworks@sfasu.edu. 


\section{National Register Eligibility Testing of 41MM340 and 41MM341, along Little River, Milam County, Texas}

\section{Licensing Statement}

This is a work produced for the Texas Department of Transportation (TxDOT) by the report producer. TxDOT and the report producer jointly own all rights, title, and interest in and to all intellectual property developed under TXDOT's contract with the report producer. The report may be cited and brief passages from this publication may be reproduced without permission provided that credit is given to both TXDOT and the report producer. Permission to reprint an entire chapter, section, figures or tables must be obtained in advance from either the Supervisor of the Archeological Studies Branch, Environmental Affairs Division, Texas Department of Transportation, 125 East 11th Street, Austin, Texas, 78701 or from the report producer. 


\section{National Register Eligibility Testing of 41MM340 and 41MM341, along Little River, Milam County, Texas}

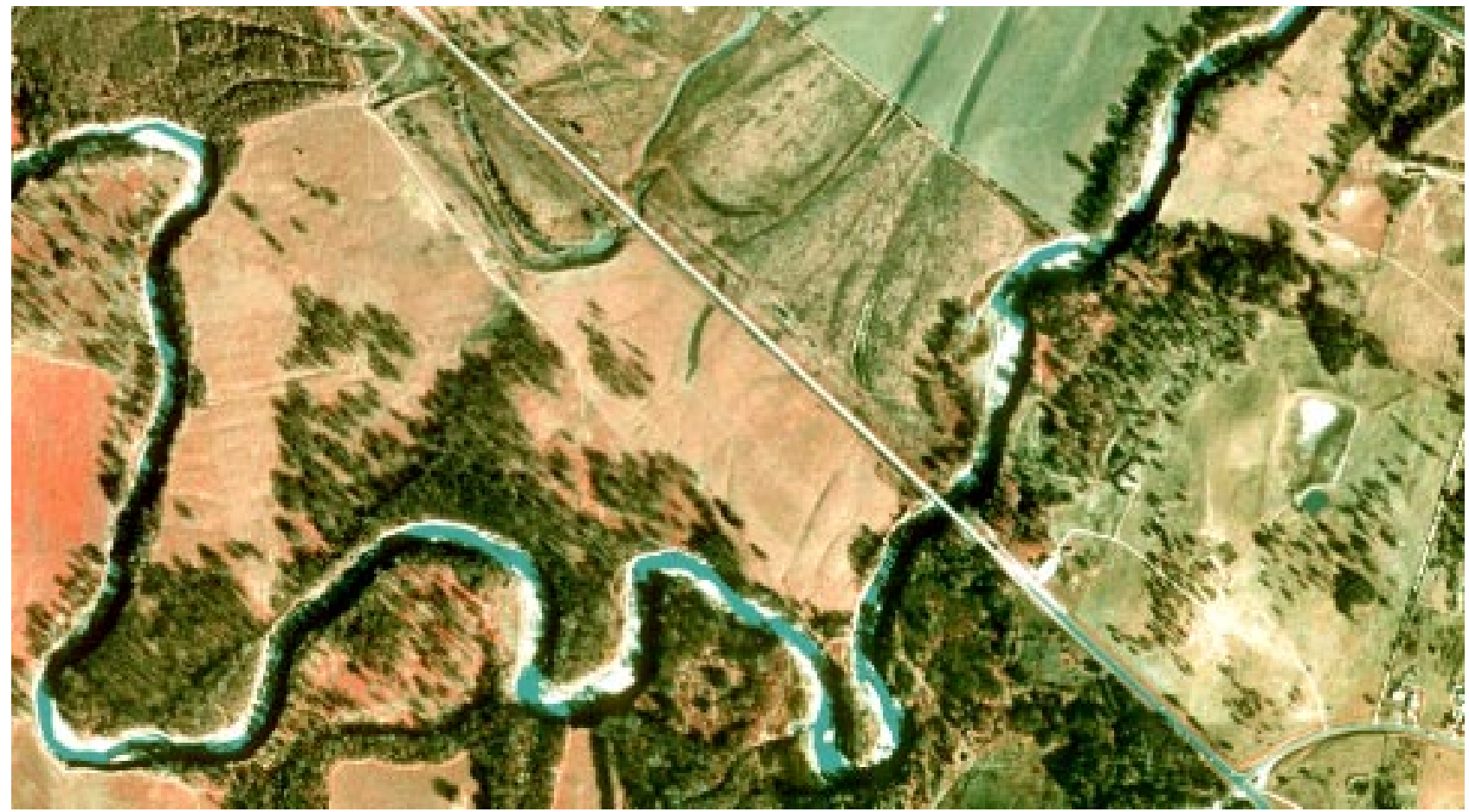

by

Richard B. Mahoney, Steve A. Tomka

with Contributions by

J. Philip Dering, Richard W. Fullington, Robert G. Howells, John G. Jones, Raymond P. Mauldin, Barbara A. Meissner, Lee C. Nordt, Timothy K. Perttula, and Barbara Winsborough

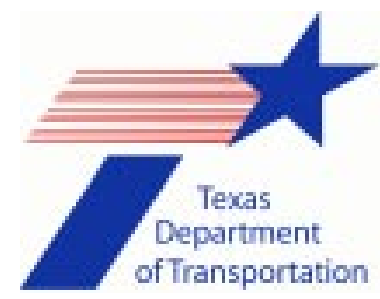

Environmental Affairs Division

Archeological Studies Program, Report No. 30

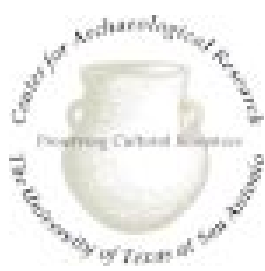

Center for Archaeological Research The University of Texas at San Antonio Archaeological Survey Report, No. 303 
ISBN: 1-930788-11-8 


\title{
National Register Eligibility Testing of $41 \mathrm{MM} 340$ and $41 \mathrm{MM} 341$, along Little River, Milam County, Texas
}

\author{
by \\ Richard B. Mahoney and Steve A. Tomka
}

with Contributions by

J. Philip Dering, Richard W. Fullington, Robert G. Howells, John G. Jones, Raymond P. Mauldin, Barbara A. Meissner, Lee C. Nordt, Timothy K. Perttula, and Barbara Winsborough

Texas Antiquities Committee Permit No. 2319

Robert J. Hard and Raymond P. Mauldin

Principal Investigators

Prepared for:

Texas Department of Transportation

Environmental Affairs Division

Archeological Studies Program, Report No. 30

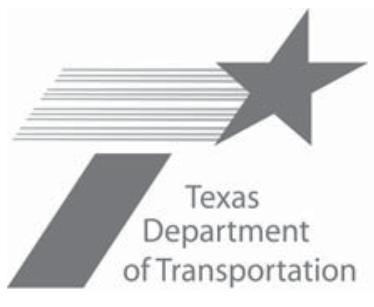

March 2001

Prepared by:

Center for Archaeological Research The University of Texas at San Antonio Archaeological Survey Report, No. 303

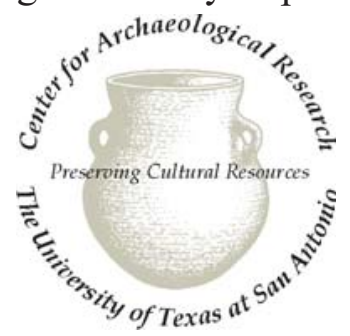




\title{
National Register Eligibility Testing \\ of $41 \mathrm{MM} 340$ and $41 \mathrm{MM} 341$, along Little River, Milam County, Texas
}

\begin{abstract}
Copyright ${ }^{{ }^{\circ}} 2001$
Texas Department of Transportation (TxDOT) and Center for Archaeological Research, The University of Texas at San Antonio (CAR-UTSA)
\end{abstract}

\section{All rights reserved}

TxDOT and CAR-UTSA jointly own all rights, title, and interest in and to all data and other information developed for this project. Brief passages from this publication may be reproduced without permission provided that credit is given to TxDOT and CAR-UTSA. Permission to reprint an entire chapter, section, figures or tables must be obtained in advance from the Supervisor of the Archeological Studies Program, Environmental Affairs Division, Texas Department of Transportation, 125 East 11th Street, Austin, 78701. Copies of this publication have been deposited with the Texas State Library in compliance with the State Depository requirements.

Printed by Thomas Reprographics Inc., San Antonio, Texas

March 2001

jointly published by

Texas Department of Transportation

Environmental Affairs Division

Archeological Studies Program

Nancy A. Kenmotsu, Ph.D., Supervisor

Archeological Studies Program, Report No. 30

A. McGraw, Series Editor

and

Center for Archaeological Research

The University of Texas at San Antonio

Archaeological Survey Report, No. 303

Printed on acid-free, $60 \mathrm{lb}$. paper

ISBN: 1-930788-11-8 


\begin{abstract}
From January through March 2000, the Center for Archaeological Research, The University of Texas at San Antonio conducted National Register of Historic Places eligibility testing for archaeological sites 41MM340 and 41MM341, under contract with Texas Department of Transportation. The investigations were conducted under Texas Antiquities Permit Number 2319. The Phase II testing fieldwork consisted of excavation of 20 test units across both sites to investigate significant cultural deposits encountered during the previous survey phase. Four distinct stratified cultural zones at 41MM340 and at least two cultural zones at 41MM341 were identified during the testing efforts. In concert with the archaeological field investigations, the following special analyses and studies were performed to aid the determination of site integrity and eligibility: geoarchaeology, radiocarbon, lithic, aboriginal ceramic, vertebrate faunal, freshwater mussel shell, macrobotanical, pollen, phytolith, land snail shell, amino acid racemization, and diatom. The synthesis of these analyses has provided adequate data to determine temporal integrity and recommendation of National Register eligibility for both sites. Further cultural resources investigations in the form of Phase III data recovery excavations are thus recommended for both sites prior to development.
\end{abstract}




\section{Management Summary}

National Register of Historic Places eligibility testing for archaeological sites 41MM340 and 41MM341 in Milam County, Texas was conducted by the Center for Archaeological Research, The University of Texas at San Antonio from January through March 2000. The testing was performed for the proposed Texas Department of Transportation development of State Highway 36 near the city of Cameron. Construction plans for the proposed development include erection of twin bridges, replacing the extant 1937 single bridge, spanning the 1.2 $\mathrm{km}$ floodplain of Little River. Adverse impact resultant from construction within the current and proposed additional $21 \mathrm{~m}$ rights-of-way would destroy all or portions of these two prehistoric archaeological sites.

The current cultural resources testing phase consisted of the excavation of $20,1-\mathrm{m}^{2}$ test units across the two sites. At least six distinct occupation surfaces have been identified, ranging from the Late Archaic I Period to the Late Prehistoric Period (ca. 1050 B.C. to A.D. 1450). Numerous stone tools and aboriginal ceramics were recovered and analyzed. By means of radiocarbon assays and analyses of temporally diagnostic artifacts, both sites have exhibited relatively high temporal integrity. As such, it is recommended that further cultural resources investigations in the form of Phase III data recovery excavations be performed prior to proposed development. 


\section{Contents}

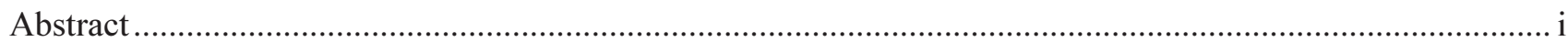

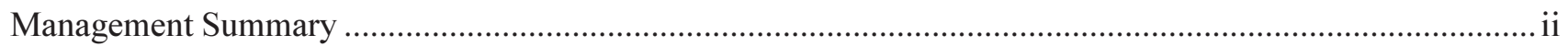

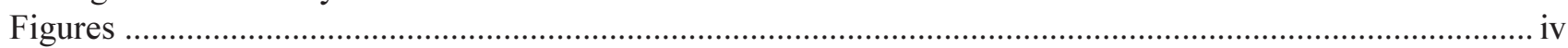

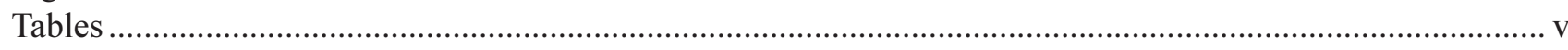

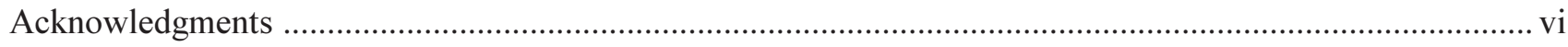

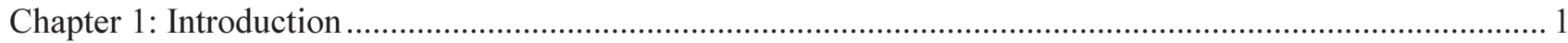

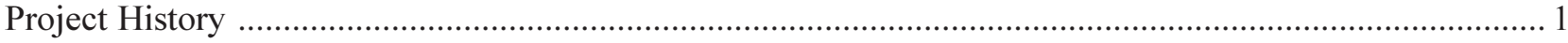

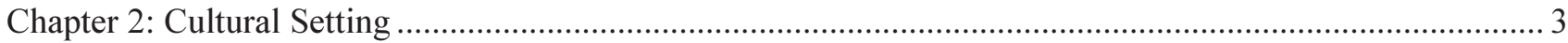

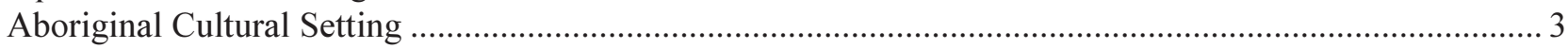

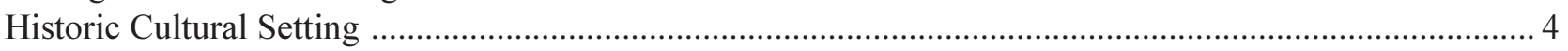

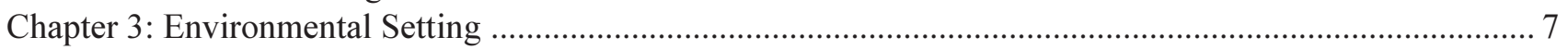

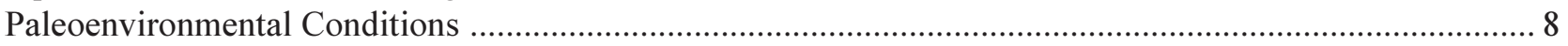

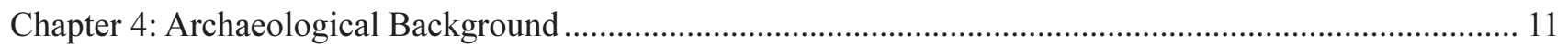

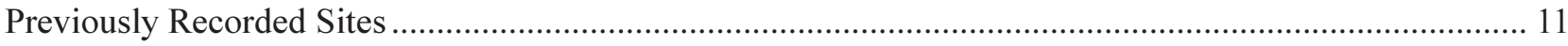

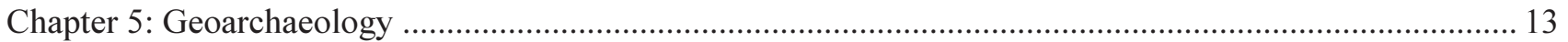

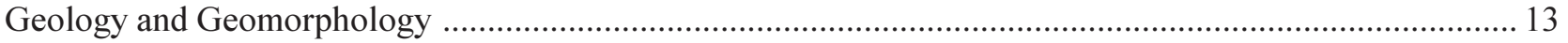

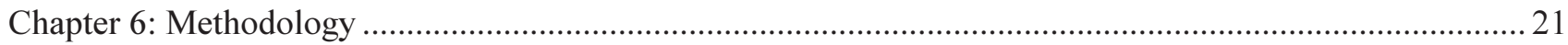

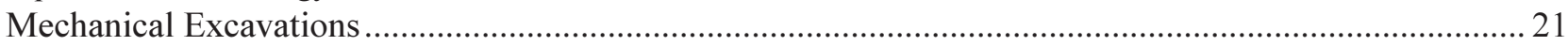

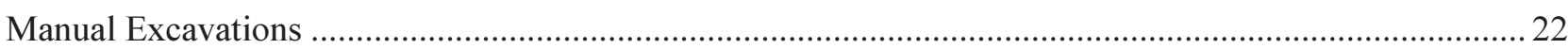

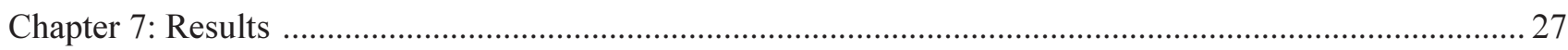

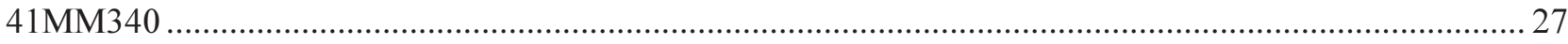

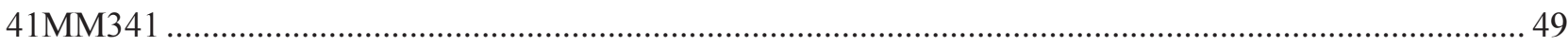

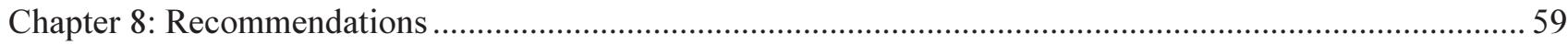

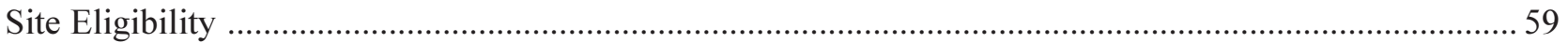

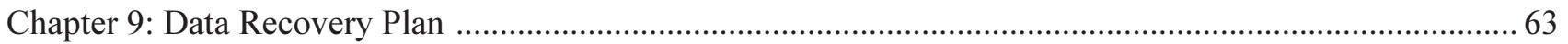

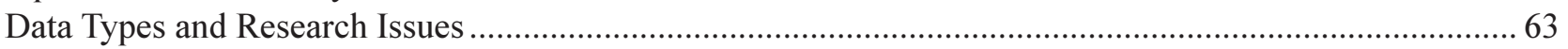

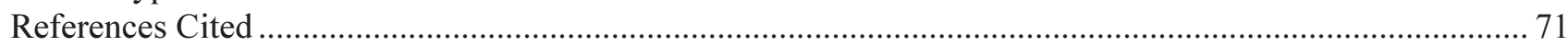

Appendix A

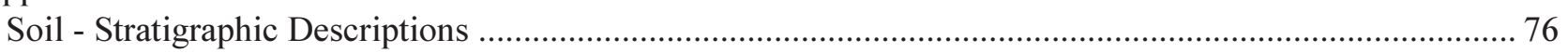

Appendix B

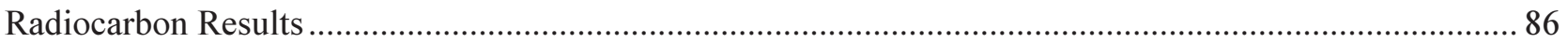

Appendix C

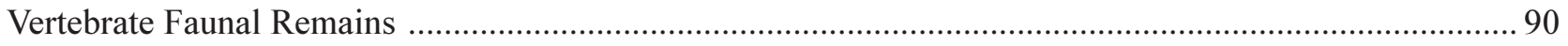

Appendix D

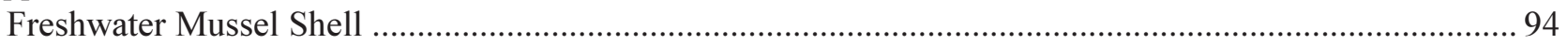

Appendix E

Appendix F

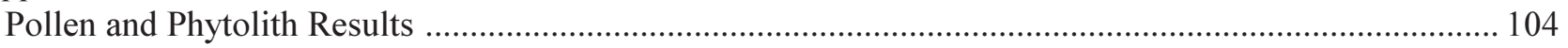

Appendix G

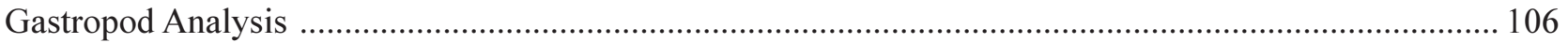

Appendix H

Diatom Paleoenvironmental Analysis of Sediments .......................................................................... 114

Appendix I

Amino Acid Racemization Values for Snail and Mussel Shell .......................................................... 120

Appendix $\mathrm{J}$

Prehistoric Ceramic Sherds from 41MM341 


\section{Figures}

Figure 1-1. General project area showing Little River and associated floodplain. ........................................ 2

Figure 3-1. Color infrared aerial photo of general project area. ............................................................ 7

Figure 3-2. Project area in relationship to Natural Regions of Texas. ...................................................... 8

Figure 5-1. Little River Basin, Milam County, Texas. ........................................................................ 14

Figure 5-2. Alluvial stratigraphic cross-section on the Project Area............................................................ 15

Figure 5-3. Detailed soil-stratigraphic profiles from backhoe localities.................................................... 17

Figure 5-4. Schematic alluvial stratigraphic cross-section of the Project Area. ............................................ 19

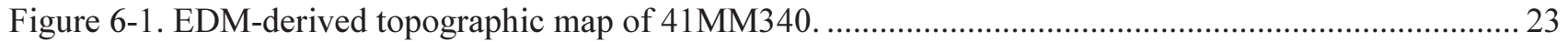

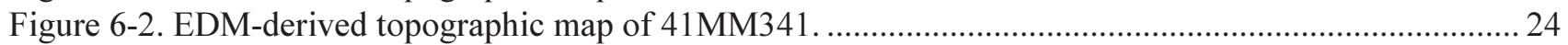

Figure 7-1. South wall of excavation Unit C, Block 2, at 41MM340 with zones identified. .........................28

Figure 7-2. Profile of south wall of excavation units C and D, Block 2, 41MM340 ................................... 29

Figure 7-3. Profile of south wall of excavation units $\mathrm{C}$ and A, Block 3, 41MM340....................................2 29

Figure 7-4. Excavation units A, B, C, and D, Block 2, 41MM340........................................................ 30

Figure 7-5. Distribution of chipped stone for all excavation units in Block 1 and Unit B, 41MM340.......... 30

Figure 7-6. Distribution of chipped stone for all excavation units in Block 2 and Unit A, 41MM340. ......... 30

Figure 7-7. Standardized fire-cracked rock and mussel shell weights by zone, Block 2, 41MM340. ............. 31

Figure 7-8. Standardized volume of chipped stone recovered by zone in Block 3, 41MM340 .................... 31

Figure 7-9. The vertical provenience of carbon samples for Block 2, Unit C, 41MM340. ........................... 33

Figure 7-10. Probability distributions of calibrated radiocarbon dates for Block 2, 41MM340. .................... 34

Figure 7-11. Probability distributions of calibrated radiocarbon dates for Block 3, 41MM340..................... 34

Figure 7-12. A/I values for Fort Hood proveniences and 41MM340 ....................................................... 36

Figure 7-13. Total snail weight (gr.) by zone for Block 2 and Block 3 at 41MM340 .................................. 38

Figure 7-14. A/I ratios (less than 0.2) for mussel shells by zone at 41MM340 ......................................... 38

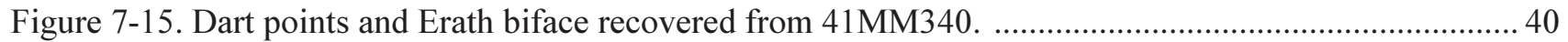

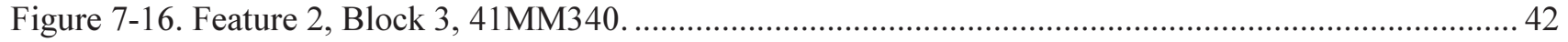

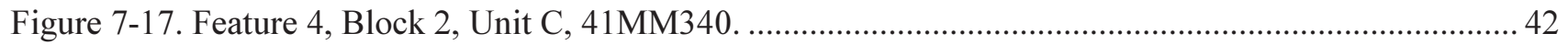

Figure 7-18. South wall of BHT 24 with occupation zones and dates of radiocarbon assays, 41MM341...... 50

Figure 7-19. East wall of Unit D, Block 2 with occupation zone and date of radiocarbon assay, 41MM341. . 51

Figure 7-20. Chipped stone tools recovered from 41MM341 .................................................................. 52

Figure 7-21. Distribution of chipped stone items by zone in Block 1 at 41MM341....................................55

Figure 7-22. Distribution of chipped stone items by zone in Block 2 at 41MM341.................................... 55 


\section{Tables}

Table 4-1. Previously recorded Prehistoric Archaeological Sites along Little River in Milam County ........... 11

Table 7-1. Beta Analytic, Inc., results of radiocarbon dating for samples recovered from 41MM340 ............ 32

Table 7-2. Radiocarbon interval estimates and deposition rates, 41MM340 .......................................... 35

Table 7-3. List of potential chronologically diagnostic artifacts recovered from 41MM340 ........................ 39

Table 7-4. Features encountered during manual excavation at 41MM340 ................................................. 41

Table 7-5. Vertical Distribution of Artifacts and Ecofacts Recovered from Block 1, 41MM340 .................. 43

Table 7-6. Vertical Distribution of Artifacts and Ecofacts Recovered from Block 2, 41MM340 ................... 44

Table 7-7. Vertical Distribution of Artifacts and Ecofacts Recovered from Block 3, 41MM340 ................... 44

Table 7-8. Standardized Artifact and Ecofact Distribution, Block 2, 41MM340 …...................................... 45

Table 7-9. Standardized Artifact and Ecofact Distribution, Block 3, 41MM340 …..................................... 45

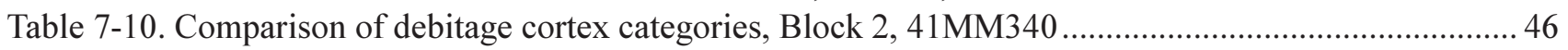

Table 7-11. Comparison of debitage cortex categories, Block 3, 41MM340 …......................................... 46

Table 7-12. Comparison of the occurrence of three flake types by zone, Block 3, 41 MM340 ..................... 47

Table 7-13. Beta Analytic, Inc., results of radiocarbon dating for samples recovered from 41MM341 ...........50

Table 7-14. Distribution of chipped stone tools and ceramics by block, unit, zone, and level, at 41MM341 .. 51

Table 7-15. Features encountered during manual excavation at 41MM341 ................................................5 53

Table 7-16. Vertical Distribution of Artifacts and Ecofacts in Block 1, 41MM341 .................................... 54

Table 7-17. Vertical Distribution of Artifacts and Ecofacts in Block 2, 41MM341 ..................................... 54

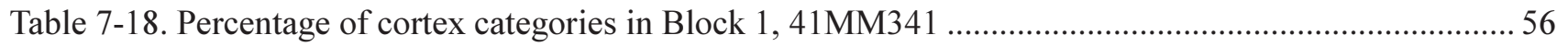

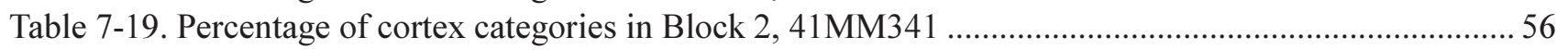

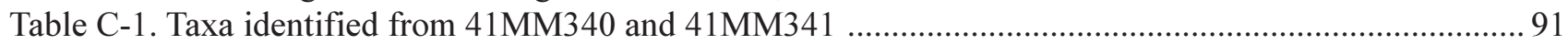

Table D-1. Identification of freshwater mussel shell remains recovered from 41MM340 and 41MM341 .....95

Table D- 2. Freshwater mussel assemblages documented at locations in the Central Brazos River Basin ...... 96

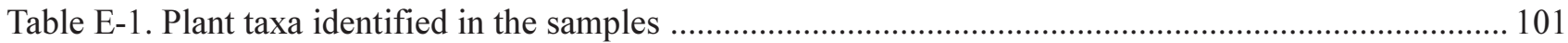

Table E-2. Flotation samples, provenience, liters floated, and identifications ........................................ 101

Table G-1. Identification of gastropod shell remains recovered from 41MM340 ................................... 107

Table G-2. Distribution of selected gastropod shell remains recovered from 41MM340 _............................ 108

Table G-3. Identification of gastropod shell remains recovered from 41MM341 ........................................ 110

Table G-4. Distribution of selected gastropod shell remains recovered from 41MM341 ........................... 111

Table H-1. Samples recovered from 41MM340 and 41MM341 examined for diatom content ...................... 115

Table H-2. Identification of diatom samples recovered from Little River and 41MM340 and 41MM341 .... 116

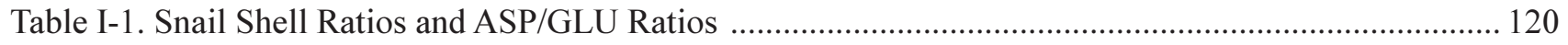

Table I-2. Mussel Shell A/I Ratios and ASP/GLU Ratios ........................................................................ 121 


\section{Acknowledgments}

Numerous individuals and organizations contributed to the success of this project, foremost among these were the field crews. During the field effort, Steve A. Tomka and Richard B. Mahoney of CAR served as Project Archaeologists. Crew members, who worked well under a variety of less than hospitable conditions included Donna Edmondson, Antonia Figueroa, Owen Ford, Brian Langner, Preston McWhorter, Barbara A. Meissner, and Brandon S. Young. Consultants on the project included Dr. J. Philip Dering, Richard W. Fullington, Robert G. Howells, John G. Jones, Lee C. Nordt, Timothy K. Perttula, and Barbara Winsborough. Steve Tomka performed the lithic analysis and Barbara Meissner analyzed the faunal material. In addition, TxDOT archaeologists Steve Ahr and James Abbott provided invaluable assistance. Bruce Moses and Richard Young of CAR drafted the excellent illustrations in the report, while Maryanne King and Johanna Hunziker, CAR editors, produced this final report. Myles Miller of THC provided critical advice on the radiocarbon dates, while Dr. G. Lain Ellis of TxDOT contributed valuable information on interpreting the snail and mussel racemization data. Special thanks to Shannon Roberts of D\&M Septic, Groesbeck, Texas; Sam Sosa of Varsity Motel, Cameron, Texas; and Jim Carter of Carter Backhoe, Cameron Texas. 


\section{Chapter 1: Introduction}

The Center for Archaeological Research (CAR), The University of Texas at San Antonio was contracted by Texas Department of Transportation (TxDOT), Austin, Texas, to conduct test excavations for two previously recorded prehistoric archaeological sites. The purpose of the current investigations was to assess the National Register and State Archaeological Landmark eligibility of sites 41MM340 and 41MM341, located within the present and proposed highway rights-of-way, prior to the proposed expansion of State Highway 36 at Cameron, Milam County, Texas. Concurrent with the archaeological investigations, geomorphological studies were conducted by Dr. Lee C. Nordt of Baylor University. The investigations were conducted under Texas Antiquities Permit Number 2319, with Dr. Robert J. Hard, former CAR Director, and Dr. Raymond P. Mauldin, CAR Assistant Director, serving as co-principal investigators. Sites 41MM340 and 41MM341 are located approximately $400 \mathrm{~m}$ (1312 ft.) and $600 \mathrm{~m}$ (1969 ft.) inland, respectively, along the left descending bankline of Little River in the central portion of Milam County, Texas (Figure 1-1).

\section{Project History}

The portion of the proposed construction affecting the Project Area is part of a more extensive TxDOT effort entitled, The Proposed State Highway 36 Bridge Replacement over the Little River and Road Widening between Travis Street in Cameron to US 77, Milam County (TxDOT CSJ: 0185-04-033 \& 034). The bridge replacement aspect of the project will extend the western right-of-way $21 \mathrm{~m}(70 \mathrm{ft}$.) and maintain the current eastern right-of-way, with the western extension the focus of the cultural resources investigations. The first phase of development will involve construction of a new bridge west of the existing bridge, ultimately providing a southbound corridor. The second phase of development involves the demolition and subsequent reconstruction of the current bridge, providing the accompanying northbound corridor. The resultant twin bridges will each measure $14.9 \mathrm{~m}$ ( $49 \mathrm{ft}$.) in width and will be separated by a distance of $22.8 \mathrm{~m}(75 \mathrm{ft}$.).

\section{8-1999 Cultural Resources Investigations}

Archaeological sites 41MM340 and 41MM341 were discovered and recorded in 1998 by TxDOT archaeologists, Steve Ahr and Jim Abbott, during a survey of the approximately 2.52 ha $(6.23 \mathrm{ac}$.) of the Little River floodplain. The survey phase consisted of excavation of 28 backhoe trenches placed at roughly $50 \mathrm{~m}$ (164 ft.) intervals across the approximately $1.2 \mathrm{~km}(0.75 \mathrm{mi}$.)-wide floodplain. Radiocarbon dating of samples extracted from various features during the survey phase suggest a date of $\sim 1050$ вр (Late Prehistoric) for the single component encountered at 41MM341 and 2800 BP (Late Archaic) for one component of 41MM340.

\section{Cultural Resources Investigations}

National Register eligibility assessment testing for sites 41MM340 and 41MM341 was conducted by CAR archaeologists from January through March 2000. Testing efforts consisted of mechanical excavation of 14 backhoe trenches and manual excavation of 20 $1-\mathrm{m}^{2}$ test units within the previously delimited site boundaries. The results of these investigations are contained herein.

\section{Report Layout}

The report is divided into nine chapters with 10 appendices. Following this introductory chapter, the Cultural Setting chapter provides a brief overview of the cultural prehistory and history of the region. The third chapter, Environmental Setting, discusses the 


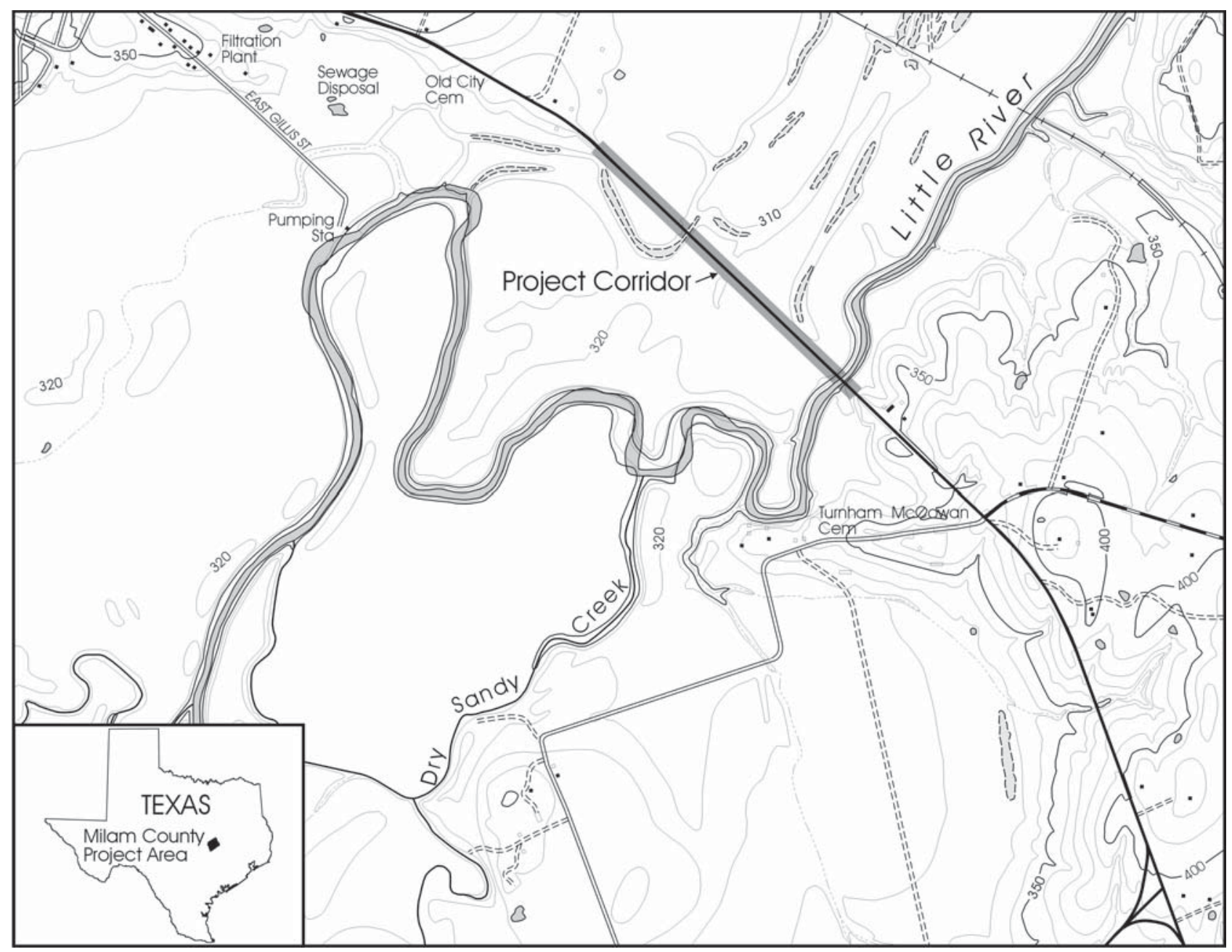

Figure 1-1. General project area showing Little River and associated floodplain. Cameron, TX USGS topographic quadrangle (7.5' series) 1961 (photograph revised 1982).

general physical environment encountered within the Project Area. Chapter Four, Archaeological Background, presents previous archaeological investigations within the region and an overview of previously recorded sites. Geoarchaeology, located in Chapter Five, discusses the geomorphology and geoarchaeological interpretations of the Project Area. The sixth chapter describes, in detail, the field methodology employed during the investigations, site descriptions, feature descriptions, and artifact descriptions. The seventh chapter discusses the results from the field and laboratory investigations at both sites. The eighth chapter presents recommendations for further work, and Chapter 9 provides a detailed data recovery plan to be implemented in subsequent mitigative efforts.
The ten appendices provide supporting data for the analysis. Appendix A provides detailed soil and stratigraphic descriptions. Appendix B contains radiocarbon data sheets. Appendix $C$ presents data on faunal material. Appendix D presents freshwater mussel data. A macrobotanical summary is presented in Appendix E, while pollen and phytolith results are discussed in Appendix F. Appendix G discusses land snails recovered from the two sites, and diatoms are discussed in Appendix H. Appendix I presents amino acid racemization results for snails and mussels, and Appendix $\mathrm{J}$ discusses the ceramics which were recovered from 41MM341. 


\section{Chapter 2: Cultural Setting}

The cultural setting of the Little River floodplain and the surrounding region is here addressed relative to the chronology exhibited by the radiocarbon samples and associated diagnostic artifacts of the cultural occupation zones. Specifically, as the oldest component encountered falls within the Late Archaic I Period, that is where our description of the Aboriginal Cultural Setting will begin. A more detailed account of the various prehistoric periods and phases here discussed, as well as the chronology of the Central Texas region in toto, can be found in Collins (1995), Johnson (1995), Johnson and Goode (1994) and Prewitt (1981).

\section{Aboriginal Cultural Setting}

Archaeologically, this interval is subdivided into two generally accepted time periods, the Late Archaic and the Late Prehistoric. The further delineation of these periods into sub-periods or phases remains a perennial topic of debate within the archaeological community. Accordingly, this brief discussion will utilize a synthesis of Johnson and Goode's breakdown of the Late Archaic (1994) and Prewitt's subdivision of the Late Prehistoric (1981).

The Late Archaic period represents the final three millennia of the Archaic Era, from approximately 4200 BP to 1200 BP (Johnson and Goode 1994:29). Adaptation to a relatively dry climate with low precipitation and high temperatures appears to mark the beginning of the period, with bison reappearing in the faunal assemblage following an over one-thousandyear hiatus (Dillehay 1974). Despite these xeric conditions, human population seems to have increased within the region (Prewitt 1985 in Johnson and Good 1994:36). Investigations conducted at the Chesser Site (41LE59), a multi-component site spanning the PaleoIndian through Late Prehistoric, suggest a substantial growth in population with the onset of the Late Archaic period, based upon increases of stone tools and lithic debitage (Rogers and Kotter 1995:134).
The commencement of the Late Archaic I phase relative to the Project Area is characterized by a generally xeric environment probably correlative with the Dry Edwards Interval to the west and southwest. This drying trend is evidenced by an overall increase in reliance on grassland species as opposed to aquatic resources among numerous sites in the North Fork Reservoir vicinity (Peters et al. 1982:16-29). Johnson and Goode propose that, due to the xeric conditions experienced by the peoples of the Late Archaic I period, burned rock middens proliferate for the processing of semi-succulents (1994:34-35). Additionally, the period is further defined by the projectile-point styles of the Bulverde, Pedernales, Marshall, Montell, and Castroville (Johnson and Goode 1994:Figure 2).

Johnson and Goode suggest Eastern (United States) religious influences, manifest in the form of various burial practices, as one of the primary indicators of the Late Archaic II phase (1994:37). The continuum of the trend toward a mesic environment can also be attributable to this period change. While a definitive date cannot be placed upon the abandonment of burned rock middens, Johnson and Goode note that these feature types are generally associated with the Late Archaic I phase, and the absence thereof denotes the beginning of the Late Archaic II phase (1994). Typical projectile-point styles of this phase include, in progressive order, Marcos, Ensor, Frio, Darl, and Figueroa (Johnson and Goode 1994:Figure 2).

Transition from the Late Archaic to the Late Prehistoric is arguably accepted to occur with the advancement in technology from hunting techniques utilizing the atlatl and dart to utilization of the bow and arrow. Additionally, the occurrence of ceramic vessels generally denotes this change of periods. The Late Prehistoric period is here defined as the time frame of approximately 1200 BP until European contact, roughly 250 BP within this region. 
Prewitt identifies the initial succeeding Late Prehistoric phase as the Austin Phase, occurring from the termination of the Late Archaic II until approximately 650 вр (1981:Figure 3). Aside from the aforementioned changes in technology, Prewitt ascribes only a slight increase in the dependence upon hunting as a means of subsistence and a marked increase in the occurrence of "true cemeteries" as an indicator of period change (1981:74). The artifact assemblage recovered from the Loeve-Fox Site (41WM230) suggests gathering takes precedence over hunting during the Austin Phase (Prewitt 1982:179). Representative artifacts include Scallorn points and Friday bifaces.

The relatively short-lived Toyah phase, as defined by Prewitt (1981), is characterized by the "dramatic" shift in subsistence from hunter-gatherer to that of an economy based primarily upon hunting. Based upon data from Dillehay (1974), bison once again reappear in the faunal assemblage of archaeological sites within Central Texas. An intermediate shift to a generally dry, mesic environment is attributed to this influx of ungulate dependence (Johnson 1995). The material culture of this time period, in the form of various stone tools utilized for bison procurement and processing such as Edwards, Perdiz, and Scallorn arrow points, along with various scrapers and other stone tools, appears to reflect a subsistence based upon the procurement of bison.

\section{Historic Cultural Setting}

Spanish exploration through present Milam County was first chronicled during the expedition of Francisco Isidro Felix de Espinosa and Domingo Ramón in 1716. Upon encountering Little River and its primary tributary, the San Gabriel River, Ramón named the streams San Andres and San Xavier, respectively. These names would persist until anglicized versions ultimately replaced them during the nineteenth century.

Representatives from the Deadose and Mayeye tribes approached the Spanish government in the 1740s to request placement of a mission along the San Gabriel River near the confluence of Brushy Creek. Mariano Francisco de los Dolores y Viana was dispatched and by 1746 had established Mission San Francisco Xavier de Horcasitas. The mission was established, in part, to attract the Tonkawa (or Titskanwatits); however, by the 1740s the Tonkawa had migrated only as far south as the Red River Valley and were not drawn to the mission (Prikryl 2001). As local interest in the mission increased, two more missions, San Ildefonso and Nuestra Señora de la Candelaria, were established in 1749. The missions attracted a diverse population, and, as such, each mission catered to a different linguistic group: San Francisco Xavier de Horcasitas contained primarily Mayeye; San Ildefonso contained Atakapan, including Akokisa, Bidai, and, Deadose; Nuestra Señora de la Candelaria contained, interestingly enough, Karankawan, primarily Coco (Chipman 1992).

Although occasionally raided by the neighboring Lipan Apache, the missions thrived and were granted a presidio in 1751 by Viceroy Conde de Revilla Gigedo. The establishment of the new presidio, San Francisco Xavier de Gigedo, brought with it the new regime of a garrison under the command of Captain Felipe de Rábago y Terán. Rábago's disdain for the missionaries and neophytes was reflected in various incidents, one of which resulted in the excommunication of the entire garrison. Due primarily to the chaos and instability of Rábago's tyranny, the neophytes ultimately abandoned the complex, and in 1755 the presidio was transferred to the San Marcos River.

In 1825, the Mexican government issued a colonization grant to the Texas Association of Nashville, Tennessee. Failure to promote the settlement of the colony lead to a string of subsequent grantees of the Mexican government, including Sterling Robertson and Stephen F. Austin. In his second bid for control of the grant, Robertson finally succeeded in colonization, and settlement of the area began. Initially named the Municipality of Viesca, the Republic of Texas renamed the district Milam County in honor of Benjamin Rush Milam in 1836.

The population of Milam County consistently rose over the following decades with an agricultural based economy. However, similar to a majority of agriculturalbased communities in the South, the Civil War and subsequent Reconstruction placed its toll upon Milam County. It would not be until the mid-1870s, when the International and Great Northern Railroad was 
constructed, providing a major artery through the county, connecting Austin and the Brazos River, a more efficient means by which to export locally produced crops was realized. Similarly, in the early 1880 s and 1890 s, the county was further serviced by the Gulf, Colorado, and Santa Fe Railroad and the San Antonio and Aransas Pass Railroad, respectively.

Within the past century, Milam County has undergone a varied swing in population and industrial technological diversions. In the $1890 \mathrm{~s}$, lignite mining became a viable natural resource of the county, providing an economic alternative to the standard of agriculture in the area. Additionally, a short boom of oil production occurred in the 1920s. Both of these industries were short-lived, however, and the population soon began a sharp decline as workers left for more productive areas. The Aluminum Company of America (Alcoa) re-engineered the process for application of lignite and, in the 1950s, revived lignite mining in the county. Currently, Milam County still relies heavily upon agriculture as an economic base, with industries providing a substantial boost to the once impoverished county. 



\section{Chapter 3: Environmental Setting}

The Project Area is located in the central portion of Milam County, Texas, approximately $1.2 \mathrm{~km}(0.75 \mathrm{mi}$.) southeast of the city of Cameron. The two sites are located within a floodplain approximately $500 \mathrm{~m}$ (1641 ft.) inland along the left descending bankline of Little River. As depicted on current USGS topographic maps and aerial photographs (Figure 3-1), the expansive floodplain is dissected by numerous sloughs, representing relict meander scars of the associated stream.

The sites are located at the border of the Blackland Prairie and Post Oak Savannah vegetation regions (Figure 3-2). Little River divides these two regions at this location. Prairie grasslands atop clayey soils predominate along the left descending bankline. The location of the sites at the juncture of these two regions and on the banks of the stream afforded diverse, seasonal resources. Indeed, Spanish exploration of the area in the mid-1700s indicated an abundance of bison, deer, turkey, fish, and wild fruits (Gilmore 1969).

According to recent, unpublished Soil Conservation Service (SCS) soil survey maps of the Project Area, $41 \mathrm{MM} 340$ is located within the Tinn series of very deep, moderately well drained, very slowly permeable soils that formed in calcareous clayey alluvium. The site sits on an apparent point bar formed by a former meander of Little River. This meander is still visible in the vicinity of the site and is part of a discontinuous line of sloughs, backwater ponds, and Green Lake. A slight escarpment ( $\sim 50 \mathrm{~cm}$ high) located along the

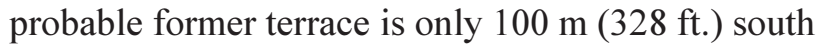
of the site.

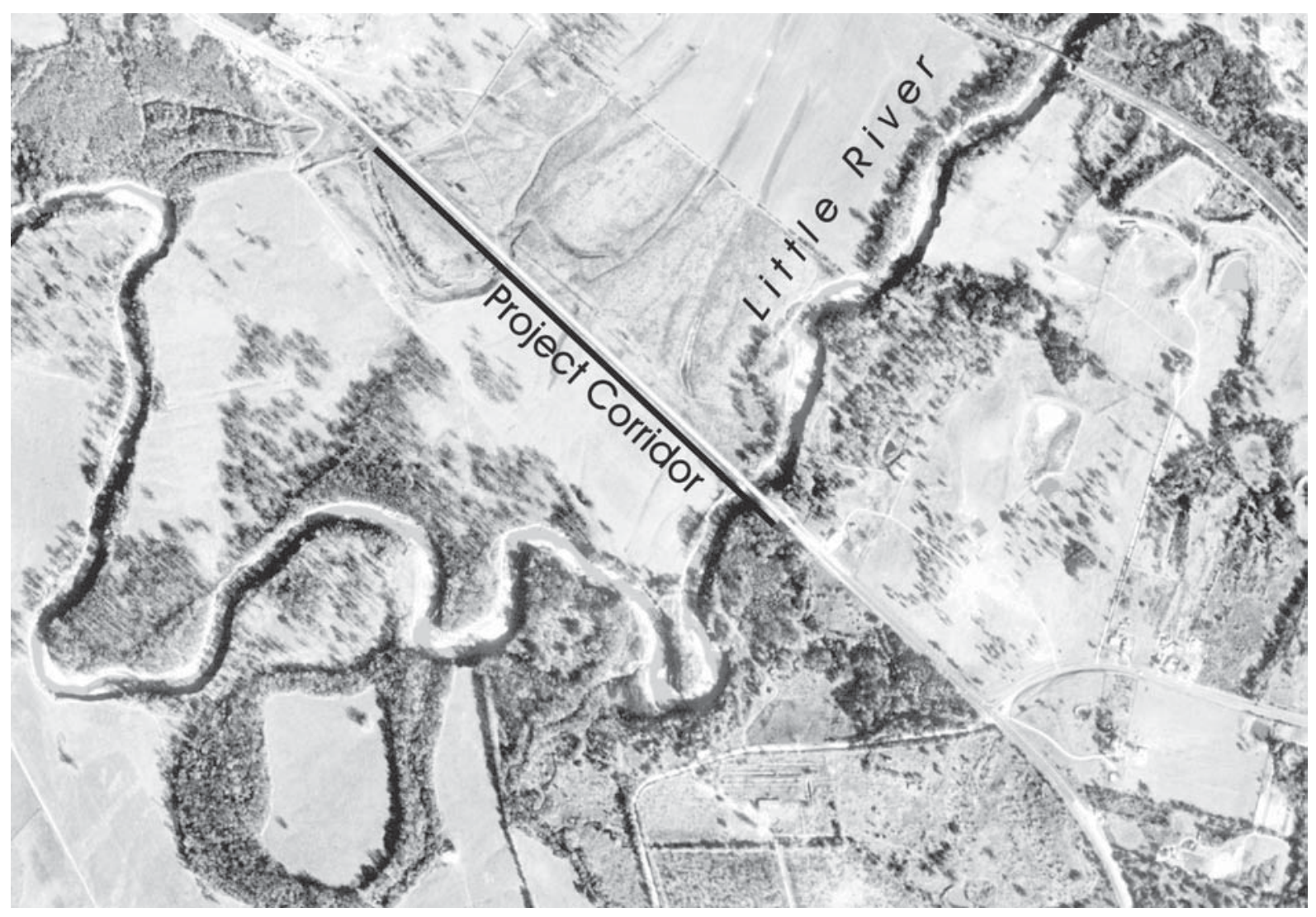

Figure 3-1. Color infrared aerial photo of general project area. 


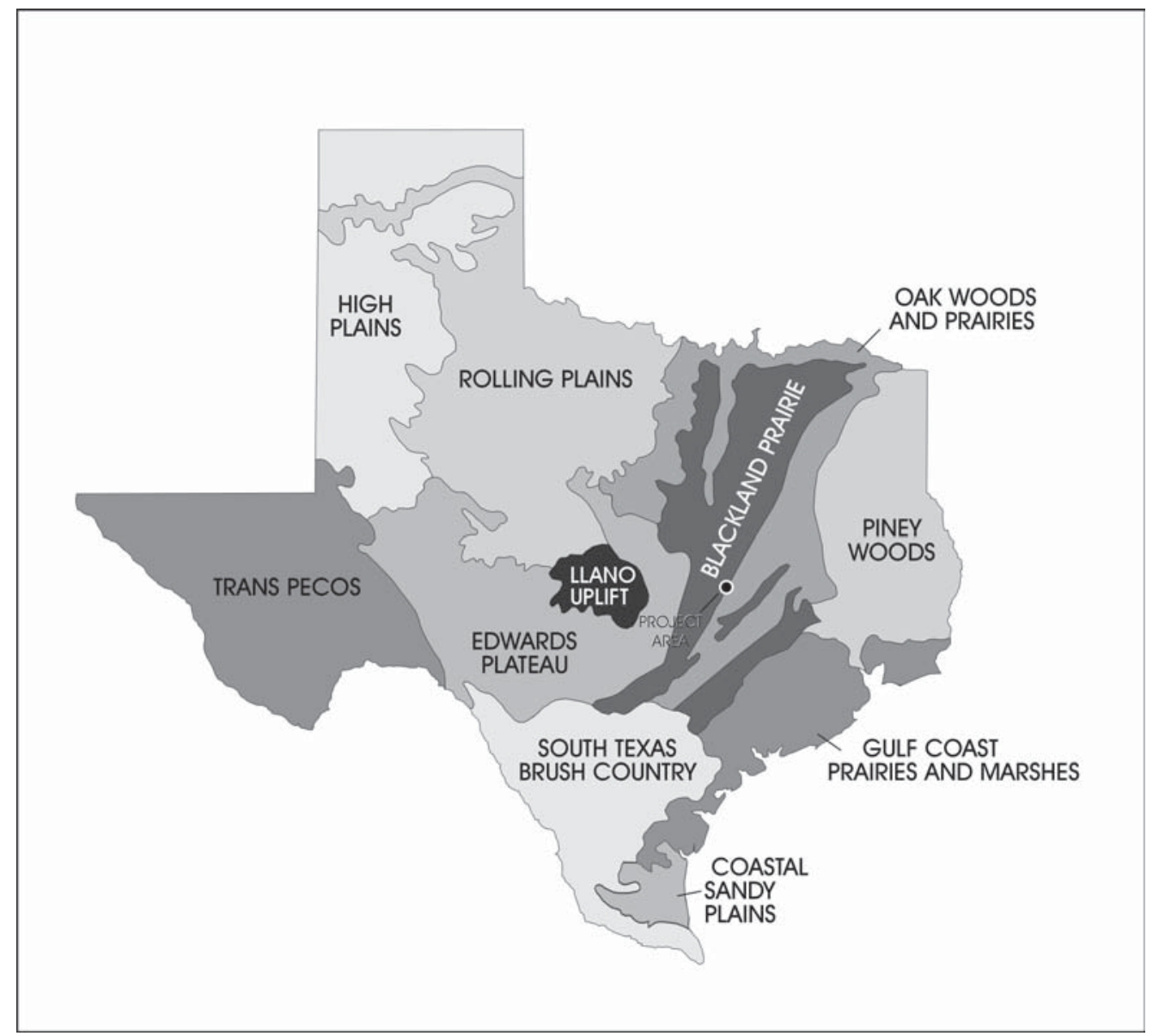

Figure 3-2. Project area in relationship to Natural Regions of Texas.

SCS maps within this soil survey depict 41MM341 within the Frio series of very deep, well-drained, moderately slowly permeable soils that formed in loamy and clayey calcareous alluvium. Classified as a Mollisol, the silty clays exhibit typical vertic properties of frequent shrink-swell dynamics. Indeed, during the testing phase, vertic cracks approximately $10 \mathrm{~cm}$ in width were noted at ground surface on both sites, and evidence of the fissures was encountered at terminal excavation depths of $1.6 \mathrm{~m}$ (5.25 ft.). It should be noted that vertic properties are not characteristic of Frio soils, and the correct assignment of soil classification would more likely be Denton or Slodell soils, which are commonly associated with Frio soils.

The area within the present and proposed rights-ofway is currently used as pasture land. The predominant vegetation is ground-cover grasses and dense giant ragweed (Ambrosia trifida) thickets, colloquially referred to as "bloodweed." A riparian zone exists along the bankline of Little River consisting of various hardwoods, primarily pecan (Carya illinioensis). Cattle are perennially maintained along the western section of the proposed right-of-way and seasonally introduced into the remainder of the right-of-way.

\section{Paleoenvironmental Conditions}

The reconstruction of the paleoenvironmental conditions characterizing the vicinity of the two Little River sites is based on pollen records from a number of localities in close proximity to the sites. These include: Gause Bog (Milam County), Boriack Bog and Patschke Bog (Lee County), Franklin Bog (Robertson County), and Weakly Bog (Leon County). Since the 
three bogs are located along the western edge of the Post Oak Savannah, these paleoenvironmental localities should reflect the long term westward movement and retreat of this boundary as climatic conditions oscillate between moister and drier conditions, respectively. Given that the Little River project area is in this same ecotonal setting, the paleoenvironmental reconstructions from these localities are highly relevant to modeling changes in resource structure and base in the vicinity of the sites in question.

Given that all indications are that the two sites were occupied during the late Holocene, the paleoenvironmental review will focus primarily on this 3,000 -year period. Although a number of bog locations are present within the general vicinity of the Little River project, many of them (e.g., Gause Bog) do not contain a pollen record from the portion of the postglacial period. Similarly, the 3700-3850 BP date from 40-50 cm bs at Boriack Bog (Bryant 1977:146) suggests that the pollen record from the last nearly four thousand years of deposition is missing. However, Weakly Bog contains a record of this approximately 3,000-year portion of the late Holocene. Here a date of 2375 radiocarbon years BP was obtained for a sample from 120-129 cm bs, and a date of 2125 вP was obtained for a zone between $58-65 \mathrm{~cm}$ bs. A date of 1550 BP obtained from $50-58 \mathrm{~cm}$ bs suggests a 500-600-year hiatus in sedimentation in the core at a depth of about $55 \mathrm{~cm}$ bs. The upper $20-30 \mathrm{~cm}$ bs represent essentially modern deposits (Holloway et al. 1987:Table 1), and using a linear regression formula between radiocarbon sample depth and age, Bousman (1998:207) suggests that the upper $16 \mathrm{~cm}$ of deposits should date after ca. 400-500 BP.

Holloway et al. (1987:75-77) interpret the lower section of the pollen spectra $(58-124 \mathrm{~cm} \mathrm{bs})$ as representing a woodland plant community that appears to have been denser than that covering the vicinity of the bog today. In part, this interpretation is based on the extremely high pollen influx values for all taxa including grasses, in conjunction with the rapid sedimentation rates characterizing these deposits. Arboreal pollen peaks between $75-104 \mathrm{~cm}$ bs starting immediately below a $2-3 \mathrm{~cm}$ thick grass mat layer that coincides with a decrease in both Poaceae and Cyperaceae pollen. The high influx values for grasses suggest that patches of open prairie may have been quite common within these woodlands.

Pollen influx values decrease significantly in the upper $52 \mathrm{~cm}$ of the core although the upper pollen assemblages do not appear to change significantly in composition. Holloway et al. (1987:76) interpret this pattern as representing a significant change in the structure of the vegetation community in the vicinity of the bog. Specifically, the lower influx value seem to suggest a more open savannah woodland setting with a greater herbaceous understory and a more prevalent grassland component. According to Holloway et al. (1987:76-77), this change appears to reflect a shift from more mesic to drier conditions and may represent the establishment of the Post Oak Savannah along this portion of the deciduous forest. This change appears to have occurred sometime between 2125 and 1550 BP. This date is younger than the 3000 Years BP date suggested by Bryant based on his analysis of the pollen record from Gause and Boriack Bogs (1977). Bryant (1977) concluded that the Oak Savannah vegetation belt within which the project area lies was established no later than 3,000 years ago and that the vegetation community has changed little since then.

Interestingly, as pointed out by Bousman (1998:207), the relative frequencies of grass and compositeae pollen does not increase as would be expected throughout the upper portion of the column. Rather, only two well-defined and isolated peaks in grass and compositeae pollen are evident. One occurs sometime around $1150 \mathrm{BP}$ at a depth of about $43-53 \mathrm{~cm}$ bs, while the other, based on Bousman's (1998:206-207) regression formula, is estimated to have occurred sometime around 400-500 years BP at a depth of between $10-20 \mathrm{~cm}$ bs. These spikes in grass pollen coincide with decreases in oak pollen and might reflect short periods of perhaps warmer and drier conditions resulting in the expansion of the prairie patches or the wholesale eastward retreat of the oak savannah. Bousman (1998:207) also suggests that the presence of pecan/hickory throughout to upper $75 \mathrm{~cm}$ portion of the column, and the appearance of pine pollen in the upper $30 \mathrm{~cm}$, in conjunction with the steady increase in arboreal pollen -with the exception of the two grass spikes- may actually be interpreted as indicative of increased moisture levels though the Late Holocene, contrary to Holloway et al. (1987). 
Due to their relative proximity to the project area, three of the more useful paleoenvironmental localities are Gause, Patschke and Franklin bogs. Unfortunately, although Patschke bog yielded a 22 foot column, Gause produced a 14 foot column, and Franklin Bog had a 10 foot column, no dates were obtained for any portion of these columns. In the Gause column graminea pollen dominated, ranging between 30 to 70 percent of the pollen. The deeper levels (below 9 feet) contain between 10-30 percent alder and chestnut pollen and chestnut continues to be present in small percentages through the 4 foot level. Oak pollen is present in small percentages $(1-10 \%)$ below the 10 foot levels but increases in proportion thereafter with one exception, a decrease in the 5-6 and 6-7 foot levels when grass pollen seems to spike. Although grass and oak pollen seems to co-dominate the Franklin Bog column, pine and birch occur in small proportions throughout the upper 5 foot levels. The invasion of the oaks and grasses in the upper levels is common to both bogs and seems to be indicative of macroregional vegetation patterns. The occurrence of birch and pine at Franklin bog may represent microregional differences compared to Gause bog. In describing the pollen records from the two bogs the authors note the gross similarity between these profiles and that yielded by Patschke bog (Potzger and Tharp 1954:464). The only main difference between the latter and the former is the more pronounced alder-chestnut period in the Patschke bog record compared to the other two bogs.

Using Bousman's (1998) reconstruction of estimated arboreal canopy cover extrapolating from the upper portion of Boriack Bog and using the data from Weakly Bog, the 2500 year period represented in the four occupation zones from $41 \mathrm{MM} 340$ has been characterized by decreasing arboreal cover between 3200-3000 BP reaching a relatively open grassland community between 3000 and $2000 \mathrm{BP}$. The increase in arboreal canopy cover between 2000-1600 BP signaled the return of woodlands and a more substantial woody vegetation component. A vegetation community dominated by grasses may have been present between 1000-1600 BP.
Sites 41MM340 and 41MM341 are located within the floodplain of the Little River, a setting with high water tables and therefore higher effective moisture levels than the adjacent upland. Such settings would have always favored the development of woodlands and forests composed of high-moisture loving and/or tolerant species. It is likely that shifts between vegetation communities dominated by woodlands and grasslands would have occurred primarily under relatively severe and long term drought conditions. Perhaps a more accurate picture of the effects of these paleoenvironmental conditions on the immediate surroundings of the site is to view them as resulting in oscillations between more closed to more open woodlands characterized by heavy woody plant components in high moisture periods and a mosaic of grasslands and woodlands during periods of lowered water tables. The surrounding uplands, where drops in water tables would have affected vegetation communities more drastically, are expected to have oscillated between relatively closed woodlands, more open woodland communities with patches of grasslands or prairies and finally grasslands as effective moisture levels decreased and water tables dropped. 


\section{Chapter 4: Archaeological Background}

Limited professional research has concerned Little River basin proper within Milam County. With the exception of a single project, the investigations regarding portions of Little River have all dealt with roadway, utility, or pipeline easements at the stream crossing. The single exception, an investigation of a small area of stream-bank erosion immediately surrounding the City of Cameron water pumping station, encountered no cultural material (Fickel 1993). TxDOT recorded two sites (41MM289 and $41 \mathrm{MM} 344)$ in addition to the subject sites of this report, during survey efforts for roadway improvement (Ahr and Abbott 1999; TSDHPT 1990; TxDOT 1999). Espey, Huston, \& Associates recorded a single site (41MM136) during a survey for Brazos Electric (Texas Archeological Sites Atlas). Survey for the AllAmerican Pipeline project, sponsored by the Bureau of Land Management, lead to the discovery of two sites (41MM272 and 41MM273) near the crossing at Little River (Turpin et al. 1992).
Conversely, the remainder of the county, as well as surrounding counties, have undergone extensive archaeological investigations due, primarily, to the presence of numerous surface lignite mines in the region. Most proximal is the Sandow Mine, which extends from the south-central portion of Milam County, southwest through the northwestern portion of Lee County; the subject of numerous investigations locating abundant prehistoric sites (e.g., Rogers and Kotter 1995; Rogers 1999).

\section{Previously Recorded Sites}

At the time of the current investigations, there were 17 previously recorded archaeological sites along Little River in Milam County. Of these, only two sites (41MM273 and 41MM289) consist solely of a historic component (Turpin et al. 1992; TSDHPT 1990). An inventory of the prehistoric sites is presented below in tabular form (Table 4-1).

Table 4-1. Previously recorded Prehistoric Archaeological Sites along Little River in Milam County

\begin{tabular}{|c|c|c|c|c|c|c|c|c|}
\hline SITE & COMPONENT & SOIL & LANDFORM & RELICT & EXTANT & SITE SIZE & QUAD & PROJECT \\
\hline $41 \mathrm{MM} 8$ & unknown & $?$ & terrace & 20 & 740 & $?$ & Hanover & Freeman Site \\
\hline 41MM12 & unknown & sandy loam & gravel pit & 60 & 2020 & 10acres & Hanover & CK Chandler \\
\hline $41 \mathrm{MM} 13$ & unknown & sandy loam & terrace & 70 & 1500 & $800 \times 200 \mathrm{~m}$ & Hanover & CK Chandler, Espey, \& SMU \\
\hline 41MM14 & unknown & sandy loam & flood plain & 40 & 1420 & 20acres & Hanover & CK Chandler; SMU \\
\hline 41MM36 & $?$ & gravel & terrace & $* 1$ & $<20$ & $?$ & Little River & Frank Bryan's \#136 (1930s) \\
\hline 41MM128 & unknown & sandy loam & upland & \# & 1560 & $?$ & Gause & Bill Moore (Texas A\&M) \\
\hline 41MM129 & unknown & sandy & upland & $\#$ & 1860 & $?$ & Gause & Bill Moore (Texas A\&M) \\
\hline 41MM130 & Late Prehistoric & sandy & terrace & $*$ & 1380 & $?$ & Gause & Bill Moore (Texas A\&M) \\
\hline 41MM131 & unknown & sandy & terrace & $*$ & 820 & $?$ & Gause & Bill Moore (Texas A\&M) \\
\hline $41 \mathrm{MM} 136$ & unknown & sandy loam & flood plain & $*$ & 140 & $12.5 \mathrm{acres}$ & Hanover & EHA, Brazos Electric \\
\hline 41MM142 & unknown & $?$ & terrace & $*$ & $<20$ & $?$ & Sharp & D Craw ford \\
\hline 41MM253 & $?$ & $?$ & upland & $\#$ & 610 & $?$ & Gause & $?$ \\
\hline $41 \mathrm{MM} 264$ & $?$ & $?$ & floodplain & 20 & 1400 & $?$ & Pettibone & ? \\
\hline 41MM292 & Late Prehistoric & $?$ & flood plain & $*$ & $<20$ & $50 \times 100 \mathrm{ft}$ & Hanover & Texas A\&M \\
\hline 41MM302 & unknown & sandy loam & upland & $\#$ & 250 & $100 \times 200$ & Gause & Bill Moore (BVRA) \\
\hline $41 \mathrm{MM} 344$ & Late Archaic & gravel & terrace & 20 & 280 & $?$ & Pettibone & TxDOT FM 1600 \\
\hline & & & & & & & & \\
\hline & & & avg & 40 & 873.75 & & & \\
\hline & & & & & & & & \\
\hline \multicolumn{9}{|c|}{ * - position relative to floodplain suggests adjacency with relict meander $(<20)$} \\
\hline \multicolumn{9}{|c|}{$\#$ - located atop upland bordering floodplain } \\
\hline \multicolumn{6}{|c|}{ ? - data not contained in report or site form } & & & \\
\hline
\end{tabular}


Little River enters Milam County from the west at the border of Bell County, follows a sinuous course, trending east-southeast through the county, toward the eastern county line, where it confluences with the Brazos River. Throughout, the Little River maintains an exceptionally wide floodplain; over $5 \mathrm{~km}$ (3 mi.) wide at certain locales. Comparison of aerial photographs and USGS topographic quadrangles reveals the history of a once dynamic stream dissecting the floodplain with numerous relict scars of former meanders.

Eight of the sites appear to be located atop terrace formations along the border of the floodplain. Four of the sites occur atop the upland, ephemerally associated with Little River proper. These upland sites appear to be exploiting the gravel deposits common along the Little River in this portion of Milam County in this location. The remaining four sites occur within the floodplain, probably representing brief encampments on former minor terraces no longer visible on the current landscape. Calculating the distance of sites to the extant meander of Little River, it is interesting to note that the average distance is approximately $870 \mathrm{~m}$ ( $\sim 1 / 2$ mile); certainly a substantial distance from such a frequently utilized resource. As such, the probable location relative to the associated relict meander has been calculated through examination of the aerial photographs and USGS maps.

Table 4-1 shows the results of this likely reconstruction, with an average, corrected distance of sites to relict meanders of Little River approximating $40 \mathrm{~m}$ (130 ft.). This corrected distance indicates a more feasible proximity of prehistoric sites to the former meander of the stream. Within such a wide, dynamic floodplain, the distance of $40 \mathrm{~m}$ allows for the variability of a changing stream and, more importantly, suggests former landforms of preferred occupation. 


\section{Chapter 5: Geoarchaeology}

\section{Lee C. Nordt}

The purpose of the preliminary geoarchaeological report is to present the stratigraphic framework for alluvial deposits and paleosols across the Little River floodplain, and to make general inferences about prehistoric site formation processes and preservation potentials. The numerical alluvial chronology is based on a combination of radiocarbon ages from the current testing project (CAR) and the previous survey project (TxDOT). Detailed soil-stratigraphic descriptions are given in Appendix A.

\section{Geology and Geomorphology}

The Little River begins at the confluence of the Leon and Lampasas rivers approximately $60 \mathrm{~km}$ upstream from the project area. Here the tributary network flows through upper Cretaceous formations consisting of limestones and calcareous muds. In the project area, the Little River flows along the strike separating the Tertiary Midway Group to the north and the Tertiary Wilcox Group to the south. The associated formations principally contain inter-bedded sandstones and mudstones. The Little River confluences with the Brazos River about $50 \mathrm{~km}$ to the east of the project area.

The Little River is a highly sinuous, suspended-load stream with a floodplain width of about $1 \mathrm{~km}$ in the project area (see Figure 1-1, 3-1). The modern channel is flowing on alluvium and is entrenched by $6-7 \mathrm{~m}$ relative to the adjacent floodplain surface. Previous hydrological analysis from a local water-discharge gauging station indicates that the floodplain is inundated with floodwaters approximately once every two years.

Pleistocene alluvial terraces are mapped on both sides of the Little River floodplain adjacent to the project area. Unpublished soil survey maps delineate these terraces mainly as Alfisols with decalcified A-Bt profiles (Minwell series), consistent with a late
Pleistocene. The floodplain soils are mapped primarily as occasionally flooded, clayey Mollisols (Frio series) with weakly developed and calcareous profiles.

Several sloughs are present across the floodplain in the study area. Cutbank exposures from the Little River to the west of the project area display clayey, channel fills that may correlate with the sloughs in the project area. Adjacent to the sloughs, the floodplain elevation is $0.5-1 \mathrm{~m}$ higher.

\section{Alluvial Stratigraphy}

\section{Valley Cross-Section}

An alluvial stratigraphic cross-section of the Little River valley in the project area was constructed using a combination of the following sources: examination of sediment cores described during bridge construction in the 1930s (Figures 5-1 and 5-2), investigation of cut bank sections of the Little River upstream from the project area, and study of re-excavated and/or newly excavated backhoe trenches across the floodplain in the vicinity of the two sites. Therefore, the model presented is somewhat different from that originally developed by TxDOT to explain valley stratigraphy.

The surface topography from the recent archaeological survey and from field observations, documented the location of three drainage sloughs $(\mathrm{C}-7, \mathrm{C}-8$; C-10, $\mathrm{C}-11$; $\mathrm{C}-17)$, two ridges (C-2, $\mathrm{C}-12)$, and intervening floodplain areas. From the cross-section, three strath surfaces cut into bedrock were identified. In the vicinity of $\mathrm{C}-1$ through $\mathrm{C}-4$ the high strath is overlain by $6-7 \mathrm{~m}$ of alluvium. The intermediate strath, from C-5 to $\mathrm{C}-17$, was cut approximately $3 \mathrm{~m}$ deeper into bedrock, with the overlying alluvium ranging from 9-11-m thick. The third strath was cut by the modern channel and is another $3 \mathrm{~m}$ deeper relative to the intermediate strath (C-18 through $\mathrm{C}-20)$. The overlying alluvium is up to $13-\mathrm{m}$ thick. 


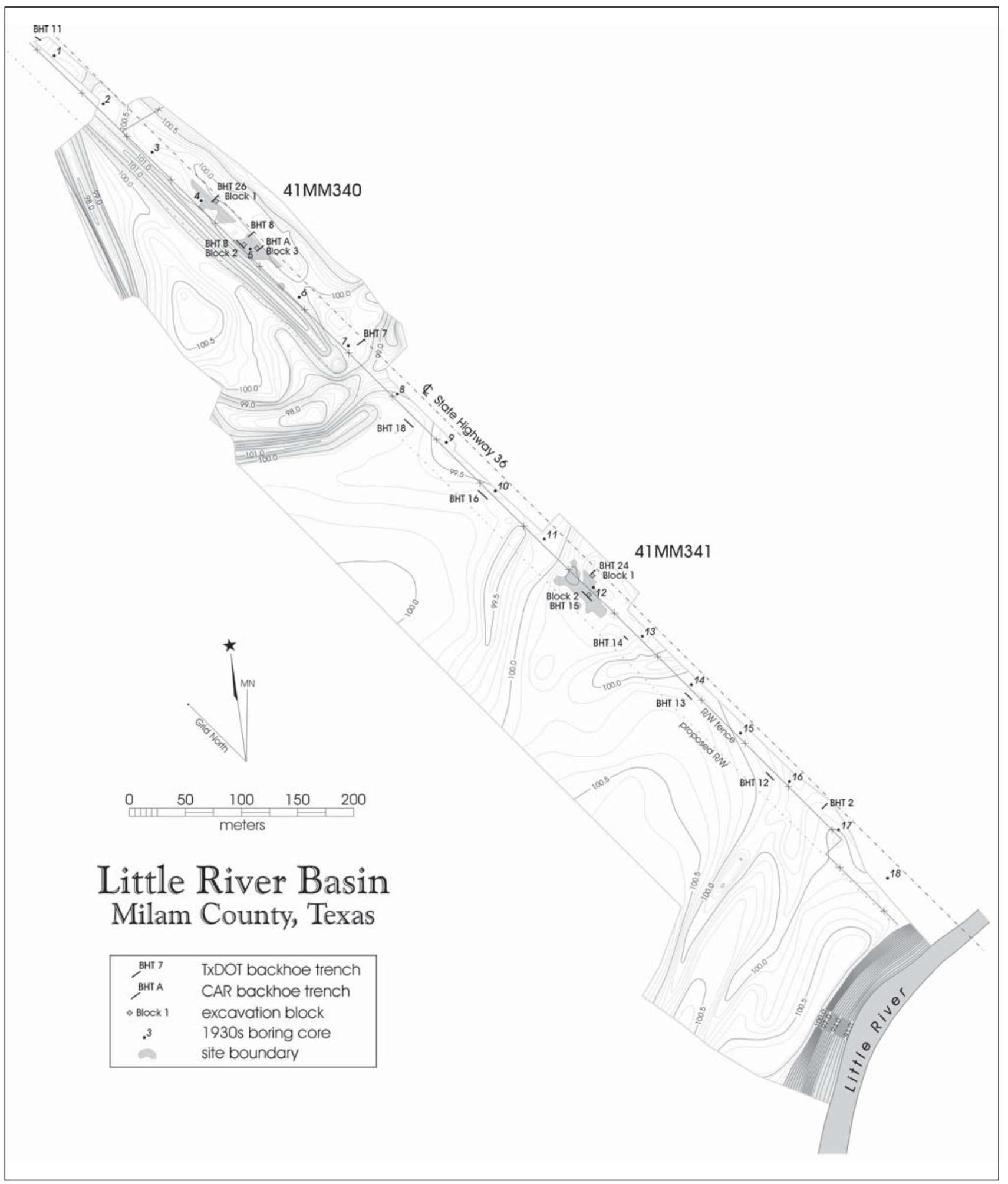

Figure 5-1. Little River basin, Milam County, Texas. 


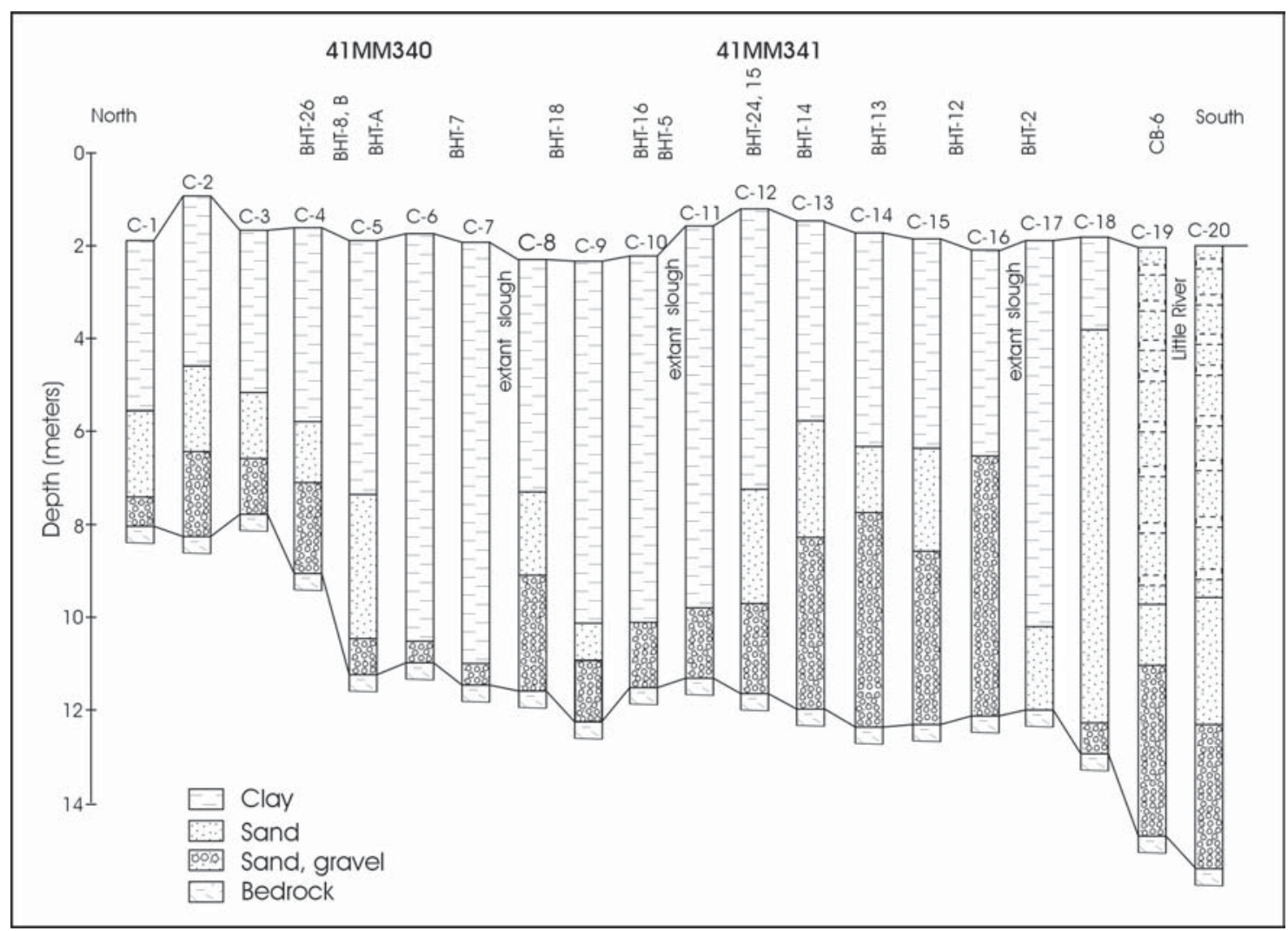

Figure 5-2. Alluvial stratigraphic cross-section on the Project Area.

Based on deep sediment cores from bridge borings taken in the 1930s. Also shown, backhoe and cutbank localities and the location of extant drainage sloughs.

Three alluvial facies were identified from the sediment cores: gravel-sand (channel), sand (point bar), and clay (floodbasin). Above the high strath on the north end of the valley, channel and point bar facies are overlain by about $4 \mathrm{~m}$ of floodbasin clays. One of the surface ridges occurs in this area (C-2). Above the intermediate strath there are three areas where thick floodbasin clays bury thin channel gravels or point bar sands (C-6, C-7; C-9 through C-11; C-17). The intervening areas consist of much thicker channel and point bar facies, with the second ridge occurring over one of these areas (C-12). Thick channel, point bar, and channel margin facies are associated with the modern channel in C-18 through C-20.

The upper elevation of the channel and point bar facies correlates across the high and intermediate straths indicating that the same channel filled the valley in this area (compare $\mathrm{C}-1$ through $\mathrm{C}-4$ to $\mathrm{C}-12$ through $\mathrm{C}-16$ ). It follows that the underling straths were scarified to different depths across the valley by the same channel. Further evidence for this scenario are the presence of well developed paleosol sequences in the floodbasin facies associated with the ridges above both the high and intermediate straths $(\mathrm{C}-2$ and C-12). In river cutbanks west of the project area, multiple gray to grayish brown channel fills were observed cut into yellowish brown and loamy point bar deposits, and buried by modern overbank sands. This indicates that the thick floodbasin clays observed in the deep cores unconformably overlie the channel and point bar facies and were deposited by a high sinuosity stream with multiple channel cut-offs. Ultimately the Little River valley filled to a common elevation with continued floodbasin deposition from the modern channel.

\section{Backhoe Trenches}

Fourteen backhoe trenches were opened across the floodplain within the project area. These trenches were reopened from the previous archaeological survey project and described again stratigraphically and 
pedologically for internal consistency. Several cutbank exposures from the Little River were also schematically interpreted. Three unconformably bound stratigraphic units were identified from exposures provided by the backhoe trenches and cutbank exposures. These units are labeled Unit 1, Unit 2, and Unit 3, from oldest to youngest.

\section{Unit 1}

Unit 1 is buried beneath the floodplain ridges in the vicinity of BHT-A, BHT-B, BHT-8, BHT-26, BHT-15, and BHT-24 (Figure 5-3; Appendix A). From the valley cross-section and from cutbank exposures, Unit 1 in the project area is probably the floodbasin facies of the thicker channel and point bar facies identified above the high and intermediate straths (see Figure 5-3). A period of landscape stability and soil formation terminated deposition of Unit 1. The subsequent clayey paleosol developed an A-Bk profile. The surface horizons are very dark gray to black and the $\mathrm{Bk}$ horizons grayish brown, brown, and olive brown with blocky to prismatic structure. The Bk horizons contain 5-10 percent carbonate filaments and in some cases 2-3 percent carbonate nodules. The thickness of this paleosol is at least $2 \mathrm{~m}$, and in the lower part, soft iron masses indicate that at some time in the past a fluctuating water table produced anaerobic conditions in this zone.

Seven radiocarbon ages were obtained from within Unit 1 and four from features resting on top of the Unit 1 paleosol. The oldest age obtained from recent dating (CAR) within Unit 1 sediments is $3070 \pm 40 \mathrm{BP}$ and the youngest $2760 \pm 30$ BP (see Figure 5-3). However, a bulk humate age of $4720 \pm 70$ вP was determined in the previous survey investigation (TxDOT) from a depth of nearly $3 \mathrm{~m}$, indicating that deposition of Unit 1 was underway by approximately this time (see Figure 5-3). The ages bracketing features resting on top of the Unit 1 paleosol range from $2420 \pm 40$ to $2600 \pm 50$ вр (see Figure 5-3). Thus, deposition of Unit 1 could have terminated as early as 2600 BP, but no later than 2420 BP. Based on radiocarbon ages from the overlying stratigraphic unit that approximate those of Unit 1, the paleosol in Unit 1 is probably cumulic, having formed during a period of depositional slowdown, and not during a period of complete cessation of flood sedimentation.

\section{Unit 2}

Unit 2 stratigraphically overlies Unit 1 . Unit 2 probably forms the upper part of the thick clayey channel facies associated with the modern sloughs in the valley crosssection and in river cutbanks. In addition, Unit 2 forms a floodbasin veneer outside of the sloughs. In, or immediately adjacent to the modern sloughs, Unit 2 occurs in BHT-16, BHT-18, BHT-7, BHT-12, BHT-13, and BHT-5 (see Figure 5-3). In floodbasin positions where burying Unit 1, Unit 2 occurs in BHT-A, BHT-B, BHT-8, BHT-26, BHT-15, and BHT-24 (see Figure 5-3). In the sloughs, Unit 2 contains faint bedding planes in the lower part, but is weathered to a weakly developed paleosol at the top. The paleosol is sometimes split by flood units. The Unit 2 paleosol consists of weak A-C or A-Bw/Bk profiles. The surface horizon is dark gray to dark grayish brown and the subsurface typically grayish brown to gray. Iron concentrations in the lower part indicate that a fluctuating water table and anaerobic conditions existed during formation of the paleosol in the slough.

In the floodbasin setting, the Unit 2 paleosol is less stratified because it accumulated more slowly and has consequently been affected more by pedogenesis. The paleosol typically has clayey A-Bw horizon sequences. The surface horizons are very dark to dark gray and the subsoils dark gray to dark grayish brown. A few profiles have up to two percent carbonate filaments.

Radiocarbon ages from within Unit 2 range from $2600 \pm 50$ to $1500 \pm 70$ BP (see Figure 5-3). Radiocarbon ages from hearths resting on top of the paleosol of Unit 2 range from $940 \pm 40$ to $1270 \pm 40$ вр (see Figure 5-3). These ages indicate that deposition was underway possibly as early as $2600 \mathrm{BP}$ and proceeded until no later than $940 \mathrm{BP}$. The interval of pedogenesis that occurred between the termination of deposition of Unit 2 and the beginning of deposition of Unit 3 is unknown other than to say the maximum could have been no more than a few hundred years. It is likely that the interval was even less, and that the paleosol in the upper part of Unit 2 is cumulic, having formed during a period of decreased flood deposition. 

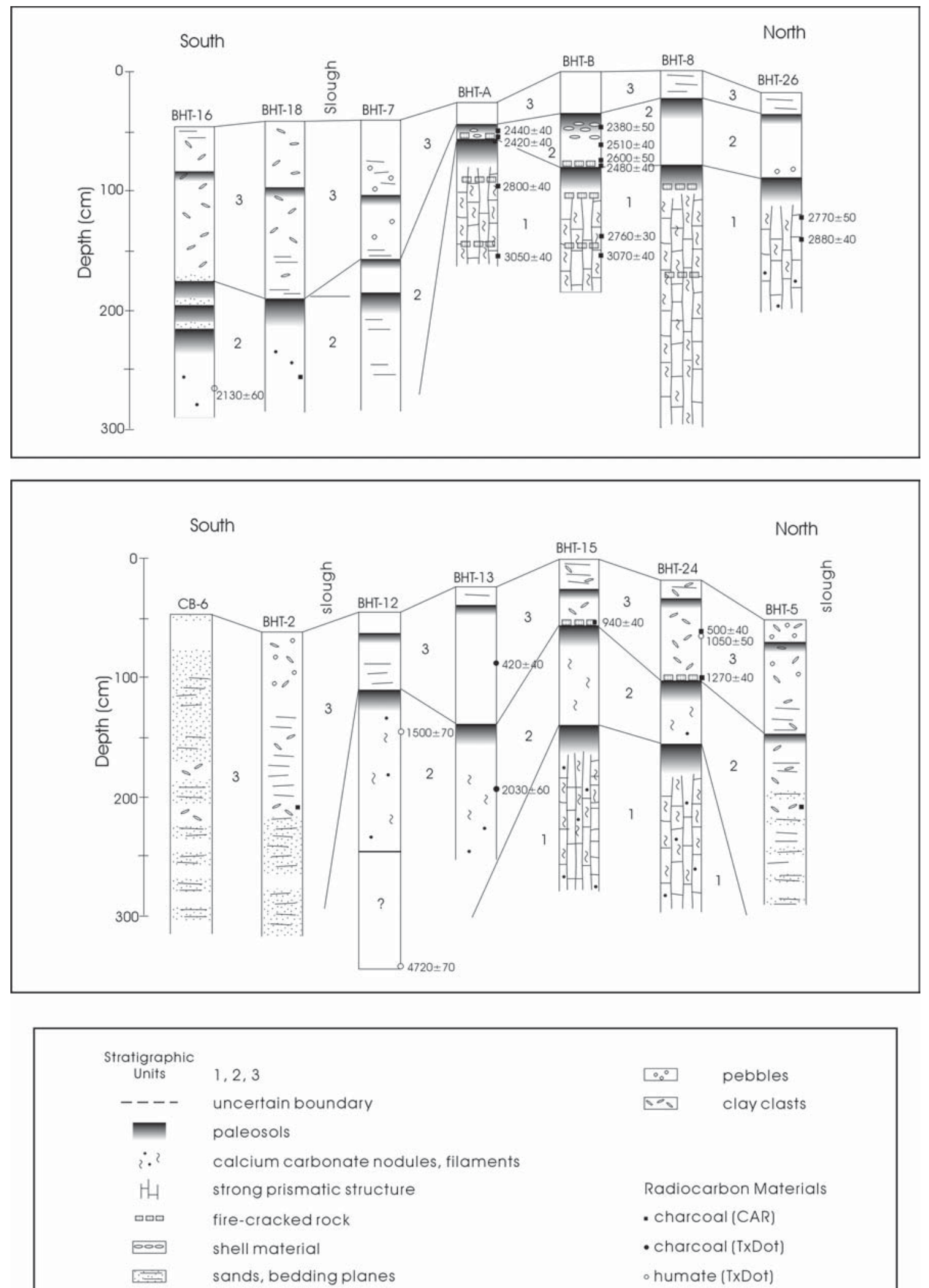

Figure 5-3. Detailed soil-stratigraphic profiles from backhoe localities showing the alluvial stratigraphic units, paleosols, radiocarbon ages, and location of archaeological materials. 


\section{Unit 3}

The channel facies of Unit 3 is deeply buried in C-18 through C-20 adjacent to the Little River (see Figure 5-2). Point bar and channel margin facies of the modern channel show thick stratified sands and silts as revealed in CB-6 and BHT-2 (see Figures 5-2 and 5-3). The lateral unconformity separating the Unit 3 channel deposits and older floodplain deposits of Unit 1 and Unit 2 probably occurs between C-17 and C-18 (see Figure 5-2). Colors are typically dark gray, brown, and pale brown in the channel facies. Unit 3 deposits also fill the upper part of the sloughs that cross the floodplain in the project area as illustrated in BHT-16, BHT-18, BHT-7, and BHT-5 (see Figures 5-2 and 5-3). These deposits are characterized by clayey and occasionally stratified loams. A third location for Unit 3 occurs in the floodbasin setting where it buries Unit 2 in BHT-A, BHT-B, BHT-8, BHT-26, BHT-12, BHT-13, BHT-15, and BHT-24 (see Figure 5-3). Unit 3 in these settings reveals similar colors, textures, and degree of stratification as in slough positions. Unit 3 typically contains an abundance of unweathered shale clasts, particularly in fine-grained units. Periodically, very brief intervals of depositional slowdown and pedogenesis occurred during deposition of Unit 3.

Based on radiocarbon ages from Unit 2, Unit 3 must be younger than 940 BP. However, radiocarbon ages directly from Unit 3 range from $1050 \pm 50$ to $420 \pm 40$ вр. The oldest age was obtained from bulk humates (TxDOT) and may be dating somewhat older than the time of deposition of the associated sediments. Unit 3 sediments are accumulating today as they are associated with flooding from the modern river.

\section{Stratigraphic Overview}

Figure 5-4 displays a schematic alluvial stratigraphic cross-section of the project area. Unit 1 is the oldest unit and ranges in thickness from 6-11 m. The basal contact unconformably rests on a bedrock strath. Unit 1 consists of a thick channel and floodbasin facies spanning the entire width of the floodplain. Facies relationships suggest deposition by a meandering, mixed-load stream. Deposition of Unit 1 began no later than 4700 BP and proceeded until approximately
$2500 \mathrm{BP}$. The surface of Unit 1 has been altered to a well-developed paleosol containing filaments and nodules of calcium carbonate. The interval of pedogenesis probably included the later stages of Unit 1 deposition when flood frequencies were decreasing.

Unit 2 stratigraphically overlies Unit 1 (see Figure 5-4). Unit 2 consists of multiple abandoned channels inset to Unit 1, and also of a thin overbank facies burying Unit 1 in floodbasin positions. The channel facies is dominated by silts and clays with a thin basal sand layer, and ranges from a few to $6 \mathrm{~m}$ thick. Facies relationships indicate deposition by a meandering, suspended-load stream. Deposition of Unit 2 occurred between approximately 2500 and 900 BP. The upper part has been pedogenically altered to a weakly expressed paleosol. This indicates that only a brief period of depositional slowdown occurred between the shift from deposition of Unit 2 to Unit 3. Paleo-sloughs of Unit 2 appear to be generally related to the position of the modern sloughs.

A period of bedrock incision occurred with the initiation of deposition of Unit 3 (see Figure 5-4). Unit 3 is up to $13-\mathrm{m}$ thick near the modern river where it is dominated by a thick channel facies. Modern sloughs are also partially filled with Unit 3 deposits because they periodically carry high-energy floodwaters as evidenced by basal sands and silts. The floodbasin facies of Unit 3 forms the modern floodplain surface across the project area. Deposition of Unit 3 has occurred during the last 900 years.

\section{Geoarchaeological Interpretations}

Prehistoric preservation potentials and site formation processes were influenced by geological and pedological processes in the study area. Unit 1 is either buried by $50-150 \mathrm{~cm}$ of floodbasin clays or eroded by Unit 2 channels to depths of 6-7 $\mathrm{m}$ (see Figure 5-3). As the Unit 1 channel migrated across the valley, the floodbasin facies probably accumulated in a relatively slowly aggrading environment. Using modern hydrological conditions of high flood frequency and duration, relatively rapid deposition of clays could have occurred in the past. The presence 


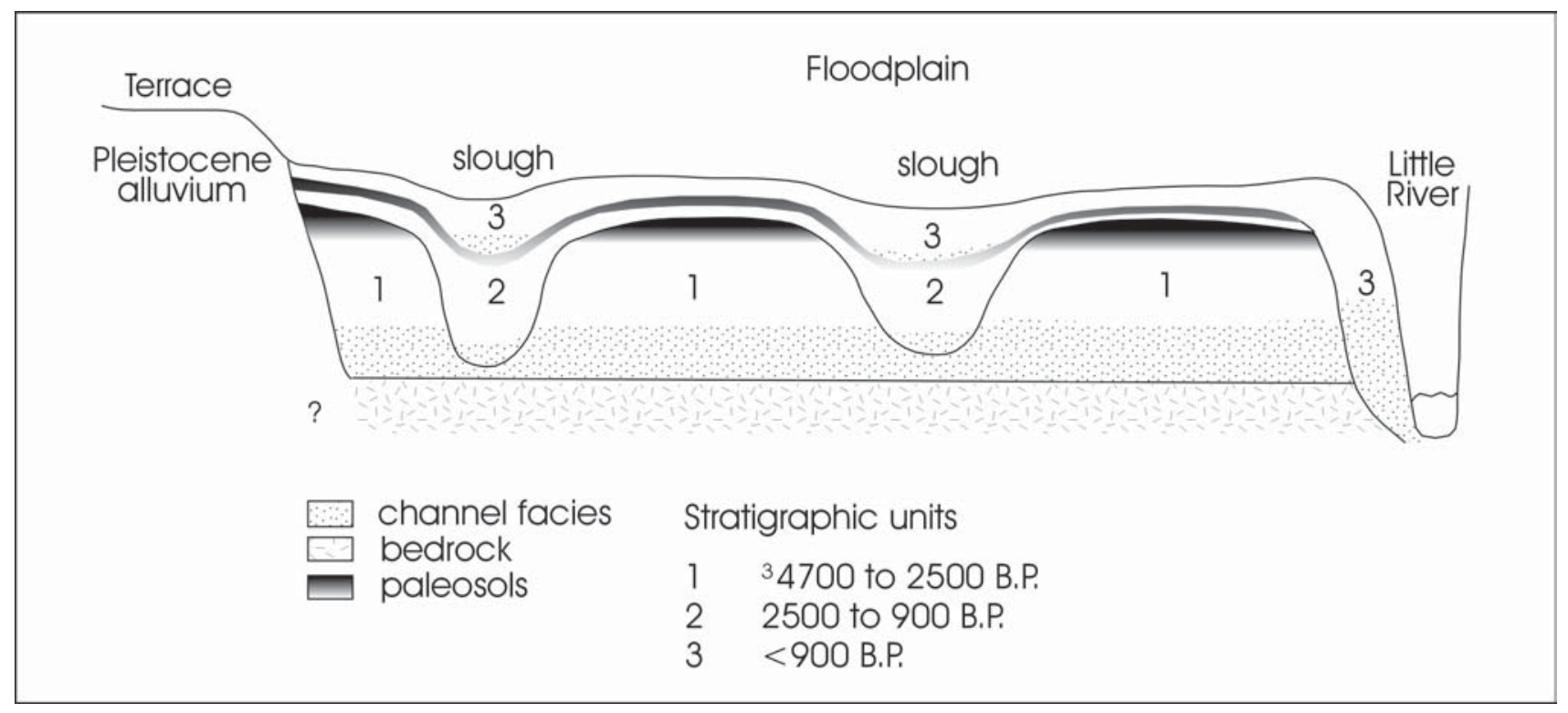

Figure 5-4. Schematic alluvial stratigraphic cross-section of the Project Area.

of two distinct occupation zones within the Bk horizon of the Unit 1 paleosol supports this interpretation (see Figure 5-3). If deposition had been slow, an over-thickened A horizon would extend to the depth of the occupation zones. Occupation zones also occur on top of the Unit 1 paleosol. Based on radiocarbon ages this paleosol is cumulic, having formed during slow deposition such that pedogenesis kept pace with deposition rather than forming during a discrete interval of non-deposition. Although high magnitude floods periodically occur in the project area, the floodwaters in prehistoric times were probably not such that significant erosion occurred outside of the sloughs. Based on environment of deposition, preservation potentials for discrete occupation zones with site integrity is high within the floodbasin facies of Unit 1 and probably on top of the Unit 1 paleosol as well. According to radiocarbon ages, the floodbasin facies of Unit 1 would contain buried sites dating to the Middle Archaic and to the early part of the Late Archaic.

Mitigating contextual integrity for Unit 1, however, are post-depositional pedogenic processes. Numerous biocasts were identified in the Unit 1 paleosol as a result of burrowing organisms. Although the paleosol contains very few slickensides, it is nevertheless clayey and subjected to cracking upon desiccation. These factors could serve as vectors for mixing archaeological materials. The paleo-location of the Little River channel and associated sloughs at the time of Unit 1 deposition is difficult to decipher. Following the geological model presented above, the sloughs as identified today and associated with Unit 2 probably did not exist during Unit 1 times.

Preservation potentials and site formation processes are similar for Unit 2 where it buries Unit 1 in floodbasin settings (see Figure 5-3). The difference is that the interval of depositional slowdown at the end of Unit 2 times was contracted based on minimal pedogenesis in the associated paleosol. However, where Unit 2 fills sloughs, archaeological interpretations will differ. Here, deposition was probably more rapid as denoted by distinct silt and sand bedding planes at depth. This would enhance the preservation of discrete occupation zones, although subsequent high magnitude floods could have occasionally destroyed previous occupation surfaces. Prehistoric occupation zones in Unit 2 would date to the latter part of the Late Archaic and to the first part of the Late Prehistoric. Overall, preservation potentials in Unit 2 should be considered at least moderate given the dominance of fine-grained textures and deposition 
in a relatively low energy environment. Cracking clays and bioturbation are also factors mitigating preservation potentials in a primary context. However, the sloughs probably do not desiccate as frequently as the floodbasin settings.

Based on the appearance of continued migration to the southeastern part of the valley, the Little River was probably closer to sites 41MM340 and 41MM341 during their formation. It is unclear whether the Little River actually occupied one of the sloughs in the project area during formation of the two sites. Even if it did not, based on the presence of a channel facies and on the thickness of Unit 2, it appears that the sloughs were carrying floodwaters more frequently during occupation than today. Thus, prehistoric occupation in floodbasin settings adjacent to the sloughs in Unit 2 probably occurred closer to a water source than what would be apparent by observing geomorphic conditions today.

Based on the absence of paleosols and presence of stratified coarse textures, deposition of Unit 3 in the project area probably occurred rapidly. Rapid deposition would lead to better preservation of discrete occupation zones, but frequent, and perhaps high velocity floods, would tend to rework features into secondary contexts. Any discovered archaeological materials would date to the Late Prehistoric or Historic. 


\section{Chapter 6: Methodology}

Pursuant to the contract between TxDOT and CAR, a total of five $2-\mathrm{m}^{2}$ blocks were excavated to investigate the two sites. The location of three of these blocks was prescribed under the provisions of the contract. The placement of the remaining two blocks was to be determined in field by means of exploratory methods. The prescribed blocks were intended to investigate specific features exposed in backhoe trenches during the survey phase. The additional blocks were to explore areas of rich cultural deposits.

\section{Mechanical Excavations}

In an attempt to relocate features designated for excavation and prospect for comparative stratigraphy, 14 backhoe trenches were reopened for the current investigations. Three trenches were reopened primarily to investigate features previously encountered during the survey phase. The remaining trenches were reopened for geomorphological interpretation of the floodplain. The trenches were excavated with a Case ${ }^{\circledR}$ $580 \mathrm{~K}$ backhoe equipped with an Extend-A-Hoe ${ }^{\circledR}$ arm attachment.

To aid the identification of clusters or concentrations of cultural deposits that would condition the placement of the additional blocks and influence future data recovery plans, a total of 202 auger borings were excavated on the two sites. A five-meter grid was maintained across the previously delimited site boundaries as identified by TxDOT during the survey phase. A standard farm tractor equipped with power takeoff (PTO) and fitted with an auger attachment (9"Ø; 4' long) aptly excavated the borings with minimal difficulty.

Two areas of dense cultural materials with some evidence of stratification were identified along the southern edge of site 41MM340 (see Manual Excavations). These areas appeared to be ideal locations for the two additional block excavations. However, to more clearly define the nature of these deposits and aid their manual excavation, two backhoe trenches were excavated within the site limits connecting two separate pairs of auger borings located in the southern portion of 41MM340. Each trench was excavated to approximately $1.6 \mathrm{~m}(5.25 \mathrm{ft}$.), the terminal excavation depth as prescribed by TxDOT.

Prior to manual excavation of each block, the upper $30 \mathrm{~cm}$ (at site $41 \mathrm{MM} 340$ ) and $40 \mathrm{~cm}$ (at site $41 \mathrm{MM} 341$ ) of sediment from $3 / 4$ of each block (three $1-\mathrm{m}^{2}$ test units) was mechanically removed. Three of the four $1-\mathrm{m}^{2}$ test units in each block were thus excavated from $30 \mathrm{~cm}$ or $40 \mathrm{~cm}$ to $160 \mathrm{~cm}$ below ground surface. The remaining test unit within each block was manually excavated from the original ground surface to a depth of $1.6 \mathrm{~m}\left(5.25 \mathrm{ft}\right.$.). In total, $16.5 \mathrm{~m}^{3}$ (582.6 $\left.\mathrm{ft}^{3}{ }^{3}\right)$ was excavated manually at $41 \mathrm{MM} 340$, and $10.4 \mathrm{~m}^{3}\left(367.2 \mathrm{ft}^{3}{ }^{3}\right)$ was excavated manually at $41 \mathrm{MM} 341$.

A settling pond was excavated adjacent to each water screening station to prevent particulate-laden water from entering nearby wetlands or Little River. The settling ponds measured approximately $10-\mathrm{m}$ wide, 20-m long, and 2-m deep. On site 41MM340 the pond was excavated off-site immediately south of the site boundary. On site 41MM341 the pond was dug offsite immediately north of the site boundary.

In order to conform to Occupational Safety and Health Administration (OSHA) standards for protection of employees in excavations (29CFR1926.652), safety benches were mechanically excavated around the perimeter of settling ponds, backhoe trenches, and excavation blocks. Each safety bench was excavated to adequate depths to maintain proper slope angles required under these provisions. No significant deposits or features were encountered during excavation of the safety benches. 


\section{Manual Excavations}

Based upon TxDOT specifications and auger boring results, five 2- $\mathrm{m}^{2}$ excavation blocks were established to investigate potentially significant deposits and features. Three $2-\mathrm{m}^{2}$ blocks were excavated at site $41 \mathrm{MM} 340$ within the existing right-of-way (Figure 61). One of these blocks, Block 1, was placed to investigate deposits associated with features exposed in Backhoe Trench 26 during survey work. The remaining two block locations, Blocks 2 and 3, were placed to investigate apparent stratified cultural deposits as indicated during auger boring excavation. Each block was subdivided into four separate $1-\mathrm{m}^{2}$ excavation units and proveniences were maintained accordingly. A total of $12,1-\mathrm{m}^{2}$ excavation units were dug.

Two 2- $\mathrm{m}^{2}$ blocks were excavated at site 41MM341, with one inside the current right-of-way and one within the proposed right-of-way (Figure 6-2). Block 1 was placed to investigate deposits associated with features exposed in Backhoe Trench 24 during survey work. Block 2 was placed to investigate deposits associated with features exposed in Backhoe Trench 15 during survey.

All of the manually excavated soils and sediments were water screened through $1 / 4$ " hardware cloth. Due to the cohesive properties of the clays within this region, it was necessary to use a deflocculent agent to expedite processing of the soils. The addition of various compounds to accelerate processing of clayey soils is common in archaeology. Laundry detergents, Calgon ${ }^{\circledR}$, and other forms of cleaning detergents have all been utilized with less than satisfactory results (Mahoney and Moore 1998). Each of these compounds are classified as polyelectrolytes that, under certain conditions, act as an expedient method of deflocculation. However, as the overall process of ion replacement with clays is not completely understood (Grim 1968:212), various geochemical factors must be calculated for the proper formula for each specific clay.

As such, a trial-by-error approach was used to determine the most efficient means by which to deflocculate the soils for water screening. Van Horn, et al. (1993) successfully utilized a method for screening clay matrices in the coastal southern California area using sodium bicarbonate as a catalyst for dissolution of excavated clay. More recently, the compound was utilized along coastal Texas processing dense silty clay alluvium (Mahoney and Moore 1998). As the sediments and soils encountered within the Little River floodplain differed only slightly from those encountered in coastal regions, it seemed likely that the compound should perform comparably.

Chemically, the addition of sodium bicarbonate causes an ion exchange reaction wherein sodium ions from the additive replace existing ions within the clay. This reaction causes the aggregate bond of the clay to fail and thereby disperses the clay into individual particles. These deflocculated particles remain separated due to their resultant charge. Aside from contributing an additional sodium component to the resultant processed matrix, the use of sodium bicarbonate should have no adverse effect upon the ecology of the surrounding environment (Dennis Neilsen, TxDOT Environmental Quality Specialist, personal communication, 2000).

Approximately $1 \mathrm{lb}$. (454 g) of sodium bicarbonate was added to roughly 3.5 gal. (13 1) of excavated material, along with adequate water to just cover the mixture. This was allowed to soak in a five-gallon bucket for at least an hour prior to water screening. During the soaking process, the mixture was stirred once or twice to expose a greater surface area to the aqueous mixture. The resultant deflocculated material flowed through the $1 / 4$ " screens much more easily than otherwise would have been possible, saving countless man-hours in the process.

A standard $1 \mathrm{~m}^{2}, 10 \mathrm{~cm}$-level of blocky clayey soils typically yields 12 five-gallon buckets filled $3 / 4$ full of excavated soils or sediments. Utilizing a formula where $1 \mathrm{lb}$. (454 g) of sodium bicarbonate is used per five-gallon bucket, each $10 \mathrm{~cm}$-level would require $12 \mathrm{lb} .(5.4 \mathrm{~kg})$ of the compound to efficiently process the excavated material. Applying the formula to the current project, approximately $3,228 \mathrm{lb} .(1467 \mathrm{~kg})$ was required to deflocculate all of the manually excavated soils and sediments. 


\section{$41 \mathrm{MM} 340$}

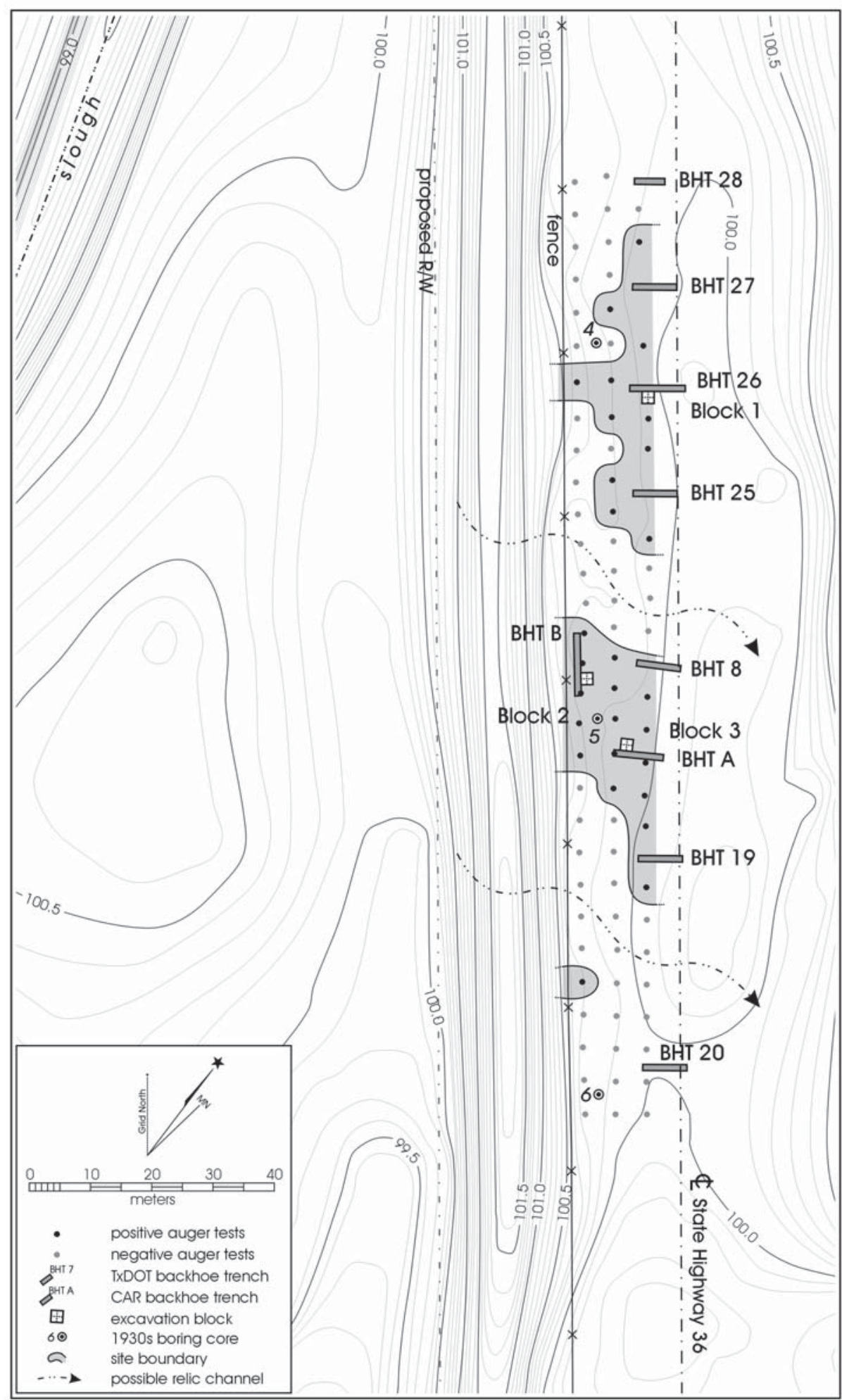

Figure 6-1. EDM-derived topographic map of 41MM340. 


\section{$41 \mathrm{MM} 341$}

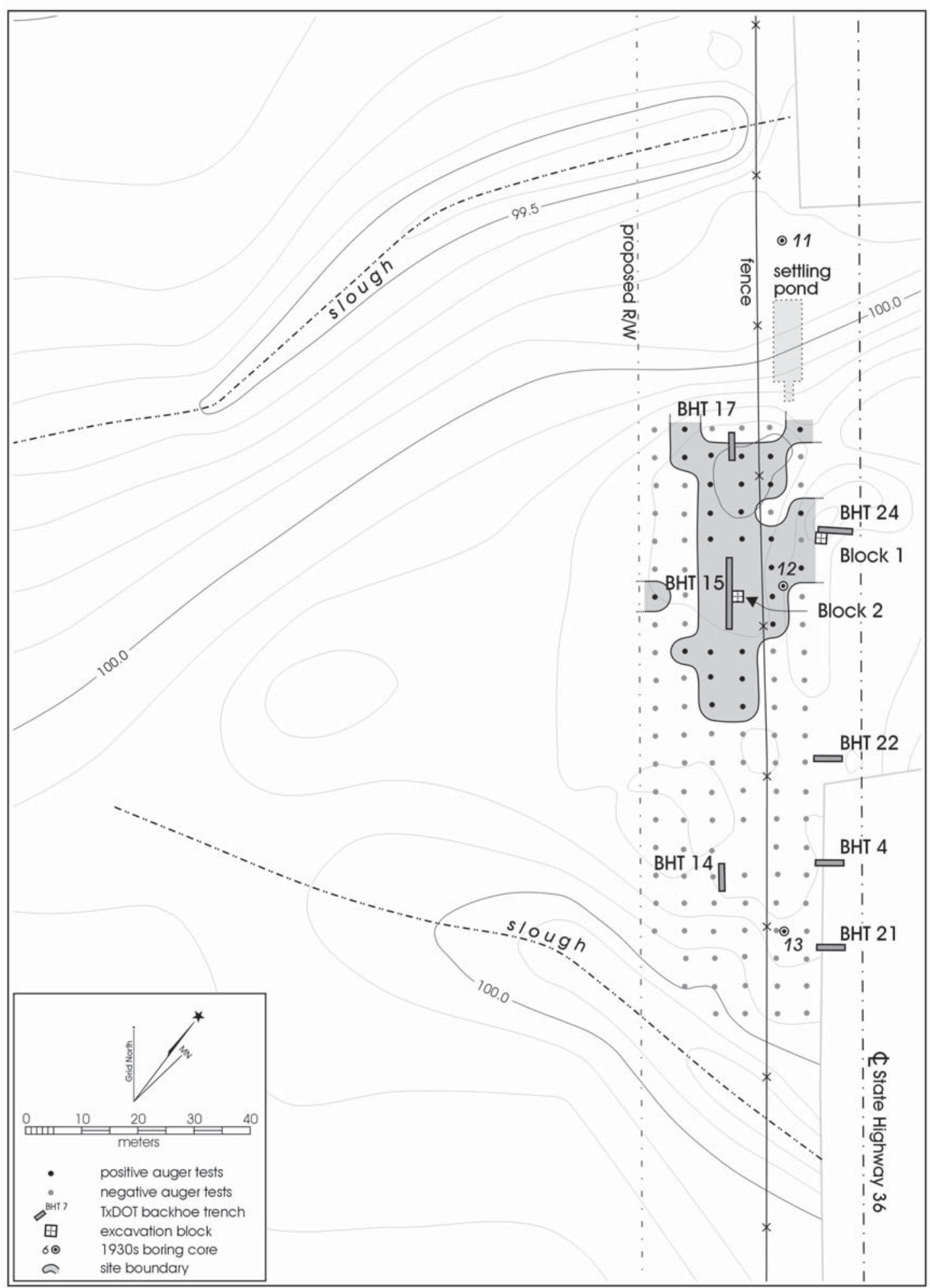

Figure 6-2. EDM-derived topographic map of 41MM341. 
Of concern to previous projects utilizing this deflocculation technique was the effect of the compound additive upon certain artifacts for dating purposes. Specifically, the effect of the compound upon charcoal has not previously been addressed in an archaeological context (Van Horn et al. 1993; Mahoney and Moore 1998). In consultation with Ron Hatfield, Beta Analytic, Inc., Laboratory Manager, it was determined that processing materials with sodium bicarbonate will not effect the absolute dating of charcoal specimens as long as the laboratory is notified, prior to processing, that sodium bicarbonate was used as the deflocculent (personal communication, 2000).

Water was supplied for the processing stations by a 2000 -gallon diesel tanker truck. On average, approximately 1,500 gallons of water was used per full day of excavation. Water was sumped from the tanker via a 5 hp engine with a water pump attachment via a $2 \frac{1}{2}$ " inlet hose. Water was then diverted to each individual station by means of a $3 / 4 "$ typical garden hose with a cut-off spray nozzle attached.

In order to facilitate the capture of runoff water, a settling pond was excavated adjacent to each water screen station to prevent particulate-laden water from entering nearby wetlands or Little River. Further, siltscreen fencing was erected around the perimeter of each settling pond to capture potential runoff in the event of overflow or heavy rains.

\section{Excavation Strategy}

All of the blocks prescribed by TxDOT (Blocks 1 and 2 of $41 \mathrm{MM} 341$ and Block 1 of 41MM340) focused specifically upon individual features and exhibited no obvious stratigraphy dictating the necessity of stratigraphic excavation. As such, the test units excavated within these three blocks were dug in arbitrary $10-\mathrm{cm}$ levels below ground surface.

However, Blocks 2 and 3 of 41MM340 did exhibit some evidence of stratified cultural deposits. As such, we attempted to excavate the eight units contained within these two blocks stratigraphically, according to the cultural zones encountered. More specifically, each zone was defined as a unique provenience, further delineated by $10-\mathrm{cm}$ arbitrary levels within each provenience. In a number of cases, the arbitrary level within a zone was less than $10-\mathrm{cm}$ in thickness.

Various samples were collected in field to provide relevant data for determining integrity and eligibility. A soil sample was collected from each arbitrary or cultural stratigraphic level of one unit within each $2-\mathrm{m}^{2}$ block at sites 41MM340 and 41MM341 throughout the vertical column. Macrobotanical (flotation processing) and microbotanical (e.g., pollen, diatoms, and phytoliths) samples were similarly collected. Mussel shell and ${ }^{14} \mathrm{C}$ samples were collected as encountered and maintained with provenience. Furthermore, all of these samples also were collected from each individual feature encountered during the manual excavations.

All cultural material encountered during manual and mechanical excavation was collected and recorded on unique field forms by provenience. These materials were processed and analyzed in a controlled laboratory setting; all recovered cultural materials are curated at CAR. 



\section{Chapter 7: Results}

\section{Richard Mahoney, Steve Tomka, Raymond Mauldin}

This chapter presents a detailed discussion of the results of the excavations at both $41 \mathrm{MM} 340$ and 41MM341. Supporting data for many of the sections are presented in the 10 appendices provided at the end of this volume.

\section{$41 M M 340$}

\section{Auger Data}

Excavation of 81 auger borings at 41MM340 revealed two distinct areal concentrations of cultural material within the site boundaries (see Figure 6-1). A 20-m (66-ft.) corridor of negative auger borings separates the two concentrations. Each of the negative auger borings within this corridor exhibited a moist to very wet soil/sediment consistency throughout. These data suggest that the two concentrations appear to have been formerly separated by a small slough or possibly an intermittent stream. It is equally possible, however, that the slough post-dates occupation of the site and has eroded through the cultural deposits.

The northern section of this site contained a relatively sparse amount of cultural material as evidenced by auger borings and backhoe trench excavations. While a diverse assemblage of cultural material was encountered, the density thereof was relegated to a relatively thin, inconsistent zone of recovery located approximately $60 \mathrm{~cm}$ (24 in.) below ground surface. Sparse to moderate scattering of fire-cracked rock, fired sandstone, chipped stone, mussel shell, bone, and charcoal comprise the majority of the recovered cultural materials from this section.

In contrast, the southern section of the site revealed a relatively abundant amount of similar materials, with at least two stratified components discernible within the auger borings. The density of materials was noticeably higher than the northern section beginning immediately south of the negative corridor. Densities increased southward for approximately $25 \mathrm{~m}(82 \mathrm{ft}$.), at which point another negative corridor was encountered (see Figure 6-1). Similarities in soil texture and moisture to the northern corridor suggest the possibility of a second stream channel. If correctly interpreted, the two ancient channels may have defined a narrow, elevated landform of preferred occupation.

\section{Cultural Stratigraphy}

The stratigraphy revealed by the mechanical and manual excavations across the southern portion of the site, represented by excavations in Blocks 2 and 3, was complex. In each of these blocks, we were able to identify nine different zones. These zones, numbered 1 (top) through 9, were defined by relatively subtle differences in sediment color and texture. These zones also contain differences in artifact content. Figure 7-1 presents a photo of Unit C, Block 2, at 41MM340 with the zones identified. Figures 7-2 and 7-3 present corresponding profiles for excavation units $\mathrm{C}$ and $\mathrm{D}$ in Block 2 and units $\mathrm{C}$ and $\mathrm{A}$ in Block 3.

Note that not all zones were represented in all excavation units. For example, reference to Figure 7-2 demonstrates that while in Unit $\mathrm{C}$ of Block 2, all nine zones were present, in Unit D, Zones 2 and 3 were truncated, being represented only in the western portion of the profile. This can be seen in Figure 7-4, a photo of all four units in Block 2. Zone 2 in this Block, characterized by a shell lens, is clearly visible in three of the units, as well as the profile of the backhoe trench at the top of the photo, but is not present in Unit B. The discontinuity in zones is also demonstrated by the observation that only Unit $\mathrm{C}$ within this Block contained all nine zones. A similar situation can be observed in Block 3, excavation unit C (see Figure 73 ), where Zones 4, 5, and 6 all converge.

As noted in the previous chapter, the testing strategy focused on isolating these various zones. While the thickness and slope of the zones fluctuated within a 
given excavation unit, the excavation followed, to the degree possible, these fluctuations. In some cases, mixing of material from two different zones may have occurred, but we are confident that this was not common. Finally, note that the northern portion of 41MM340, represented by the excavations in Block 1 , did not exhibit any clear stratification. This area was excavated in $10 \mathrm{~cm}$ arbitrary levels. However, as discussed below, artifact data suggest that within this block, at least two, and possibly three, different concentrations of cultural material are represented.

Excavations in Block 1 at 41MM340 recovered 1,975 pieces of chipped stone debitage. Figure 7-5 (top) presents the distribution of debitage by arbitrary $10 \mathrm{~cm}$ levels for all units in this block. Two, and possibly three modes are apparent in the figure, with one at level 7 and a second and possibly a third mode represented by levels 10 through 12 . Examination of the distribution of debitage by level from the four individual units, an example of which (Unit B) is presented in Figure 7-5 (bottom) demonstrates these same modes.

Figure 7-6 (top) presents a similar graph for the 4,899 chipped stone items recovered in all units from Block 2 . Here, the number of debitage has been standardized to account for the different volume of material excavated in each zone. Clearly, four different peaks are represented, with Zones 2, 4, 6, and 8 all having a high density of material. The bottom bar graph in Figure 7-6 represents Unit A in this block. Note that Zone 3 is not reflected in this unit, but peaks in debitage in the four primary zones are clearly present. Figure 7-7 (left) presents standardized fire-cracked rock weights for Block 2, while the right-hand graph in Figure 7-7 presents standardized weights for all mussel shell. These patterns, while they vary by material, reinforce the identification of Zones 2, 4, 6, and 8 as being distinctive areas with high concentrations of materials separated by zones of lower material density.

Finally, Figure 7-8 presents a bar graph of chipped stone recovered by zone in Block 3. As with the Block 2 data, these numbers have been standardized to reflect different volumes of excavated material. Four peaks are again present, though the chipped stone peak in Zone 2, which dominated Block 2, is not as prominent in this block.
Figure 7-1. South wall of excavation Unit C, Block 2, at $41 M M 340$ with zones identified.

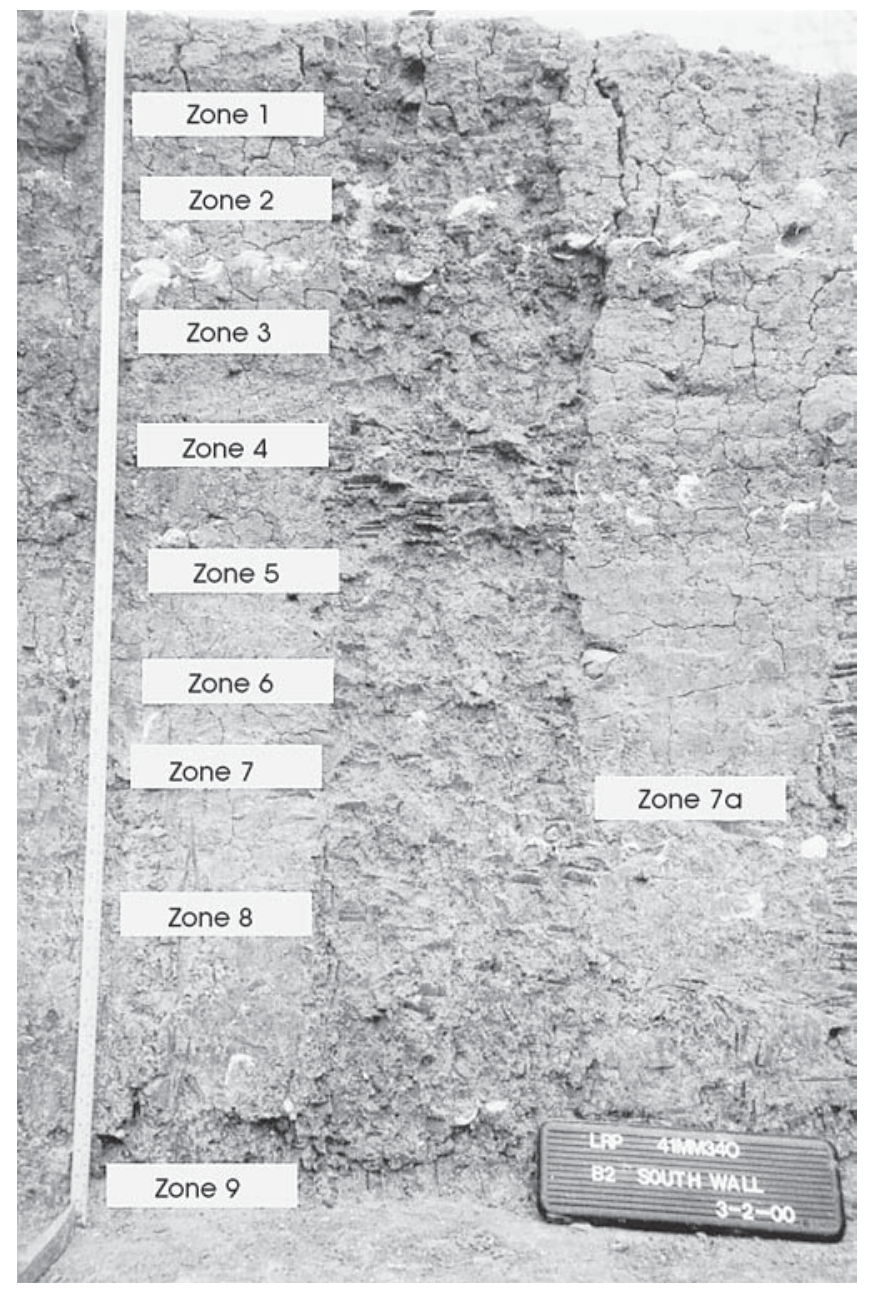

These comparisons demonstrate that the relationships between the nine zones represented in each block are complex. For example, it is not necessarily the case that Zone 4 in Block 2 corresponds to Zone 4 in Block 3. Nevertheless, both Blocks 2 and 3, separated by less than 10 meters, contained nine definable stratigraphic zones. These zones had roughly similar sediment structure, color, and texture. The zones differ in detail in terms of chipped stone, fire-cracked rock, and ecofactual content, but in each block there are data to suggest that four distinctive, cultural strata can be identified. These zones are separated by zones that, though not sterile, have relatively lower counts and weights of artifacts and ecofacts. 


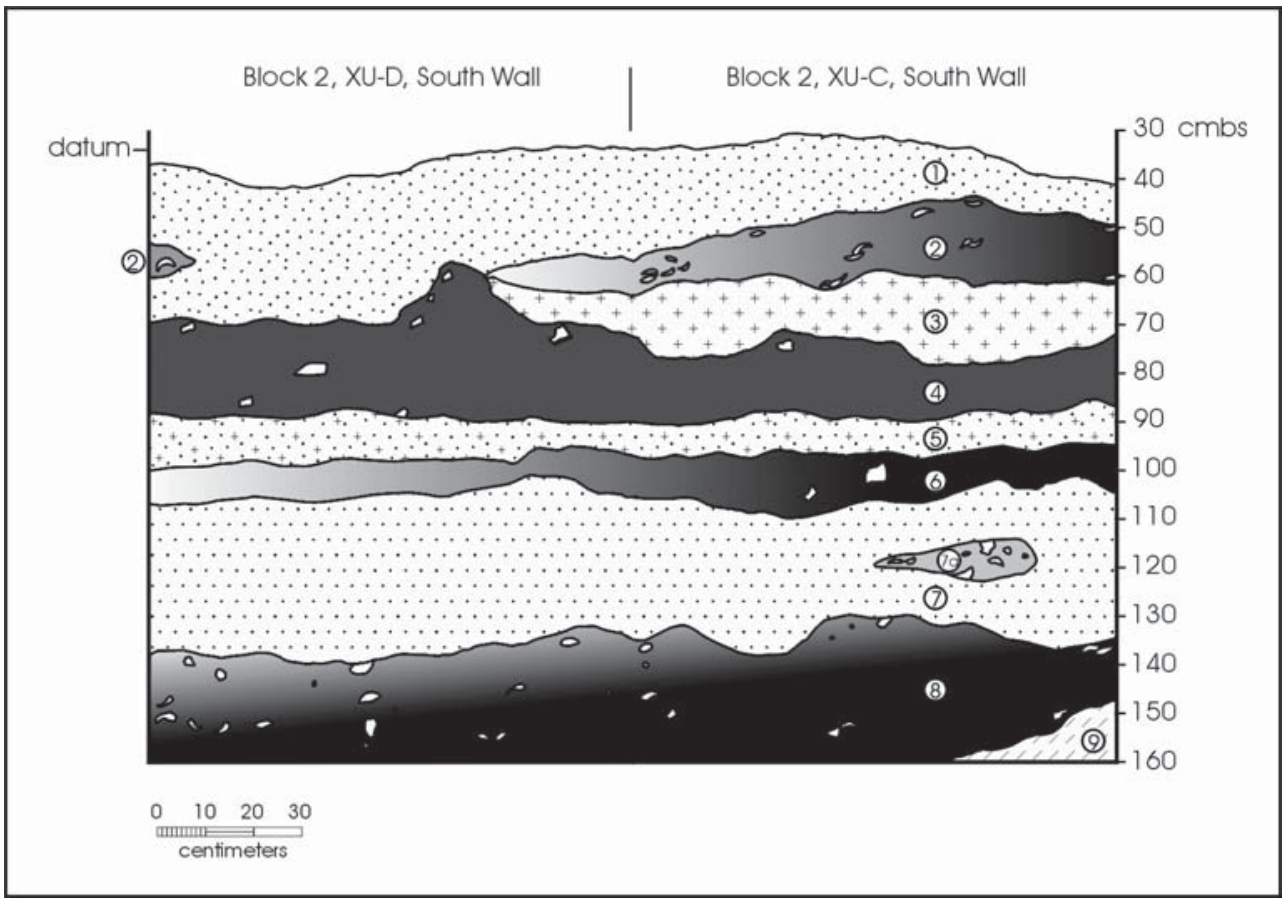

Figure 7-2. Profile of south wall of excavation units $C$ and D, Block 2, 41MM340.

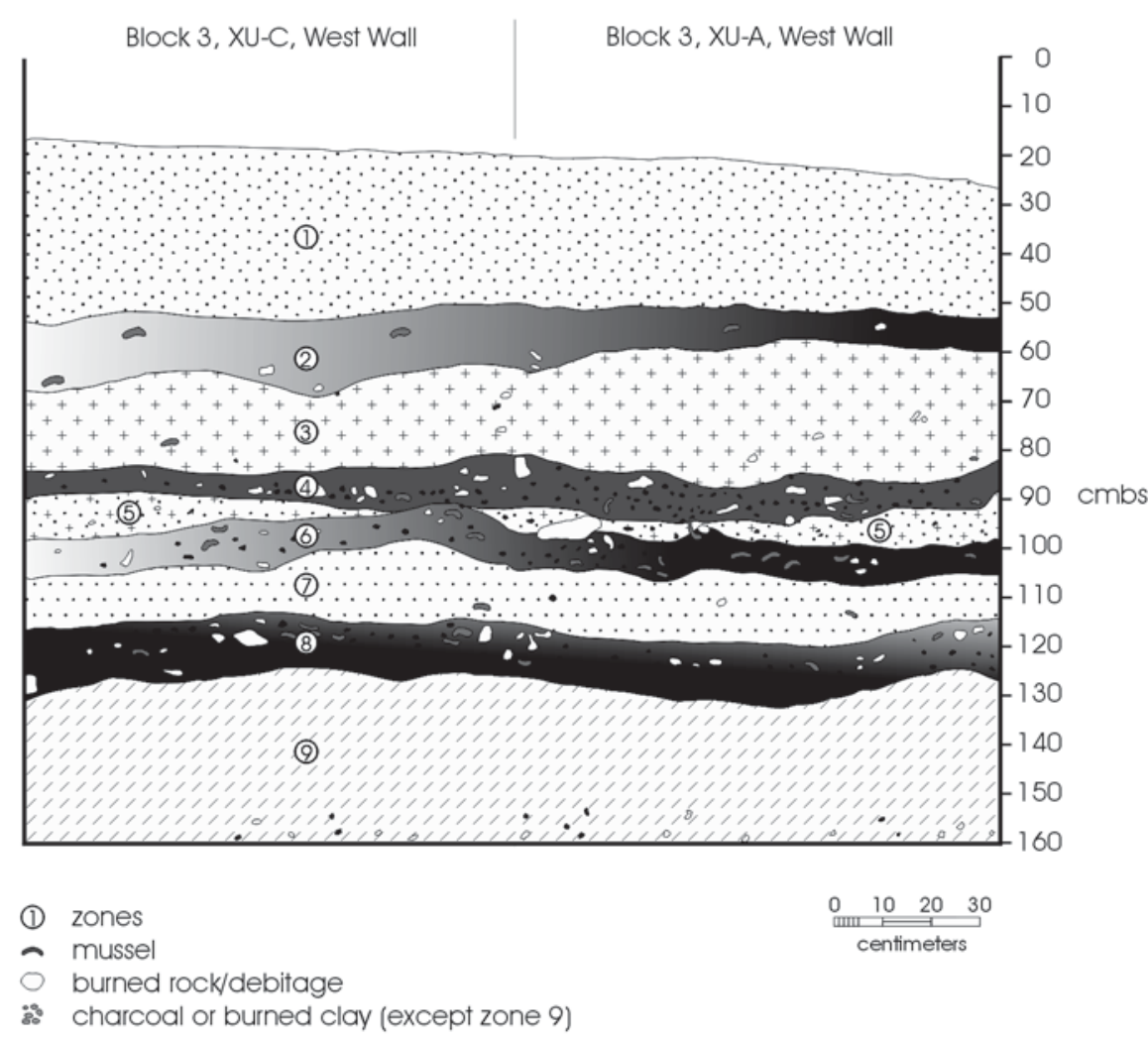

Figure 7-3. Profile of south wall of excavation units $C$ and A, Block 3, $41 M M 340$. 


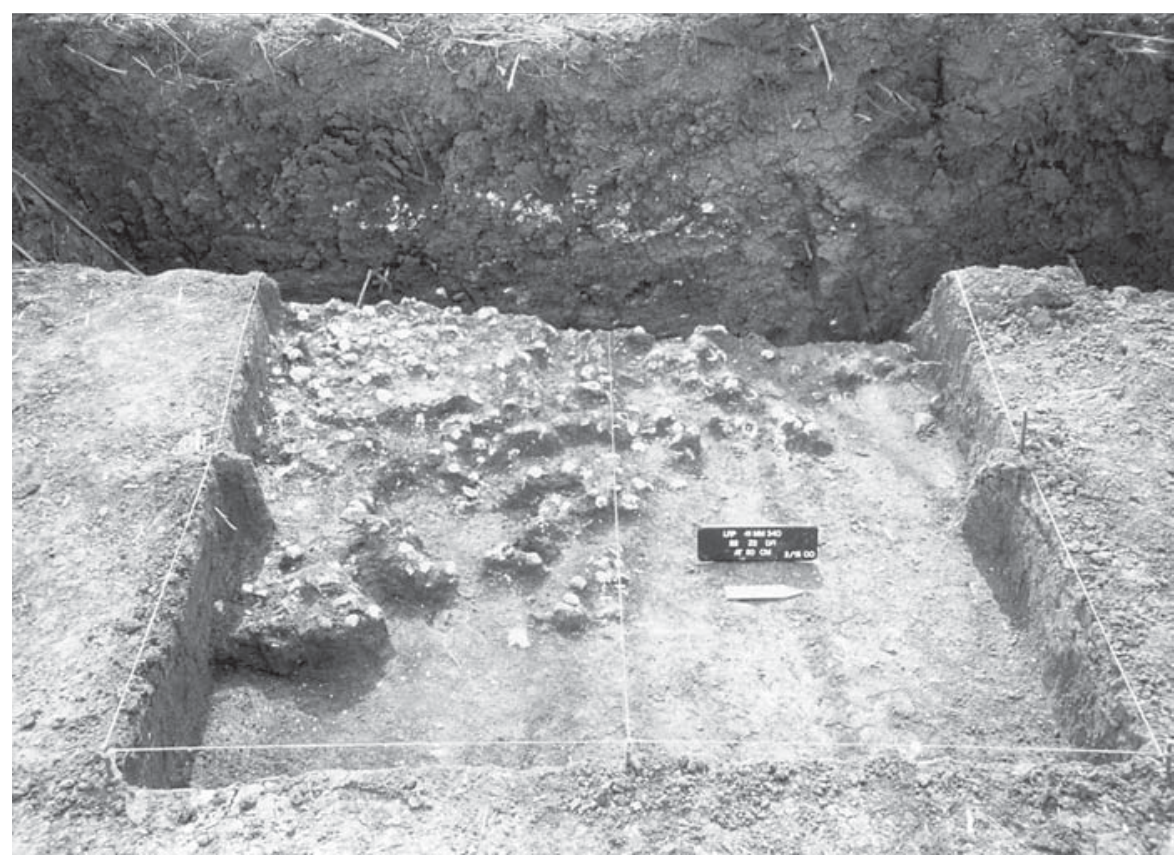

Figure 7-4. Excavation units A, B, C, and D, Block 2, $41 M M 340$.

Note continuation of shell lens in western profile of associated backhoe trench.
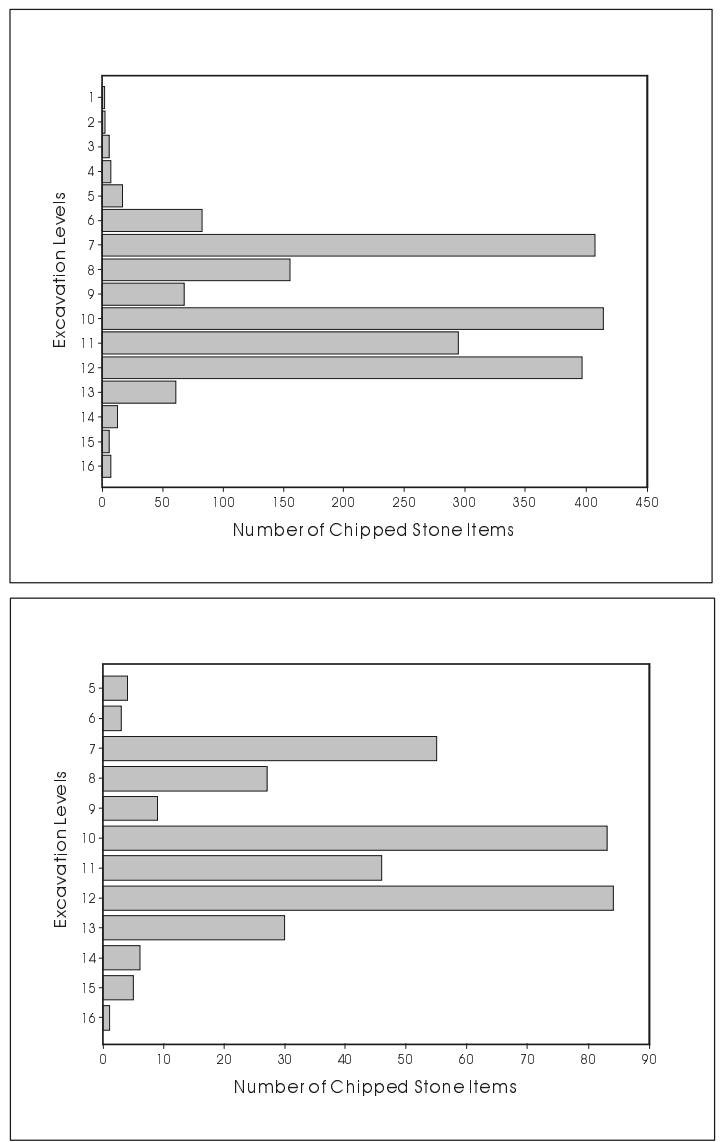

Figure 7-5. Distribution of chipped stone by level for all excavation units in Block 1 (top) and for only Unit B, Block 1 (bottom), $41 M M 340$.
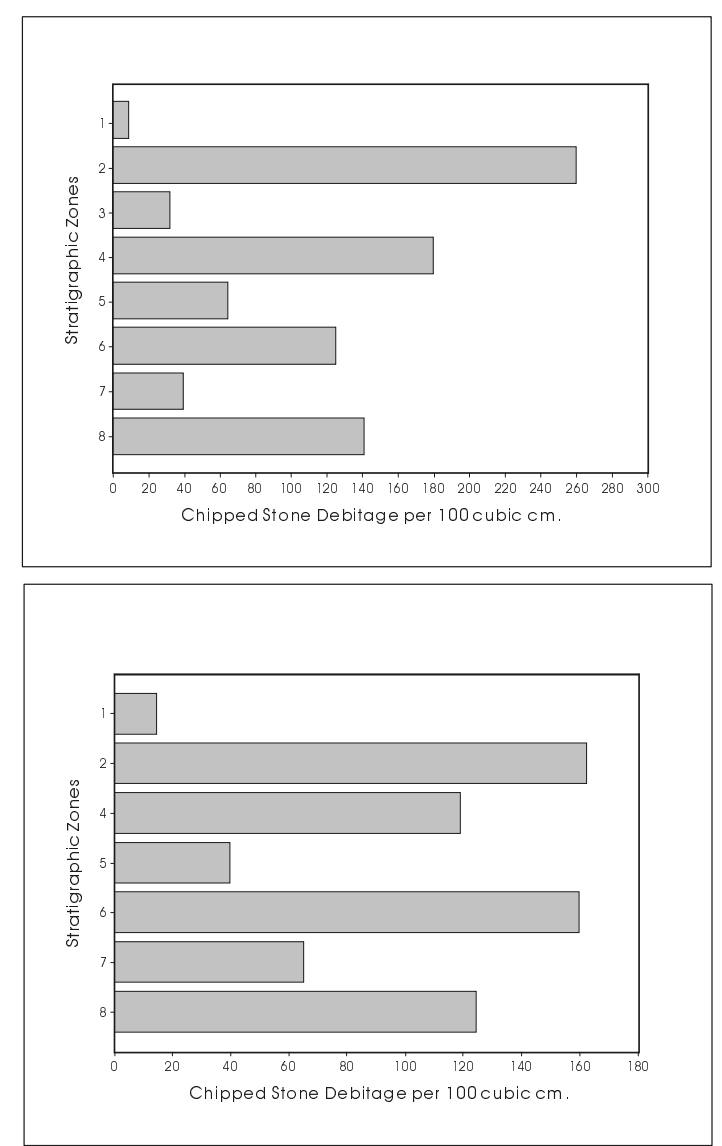

Figure 7-6. Distribution of chipped stone by level for all excavation units in Block 2 (top) and for only Unit A, Block 2 (bottom), 41MM340. 

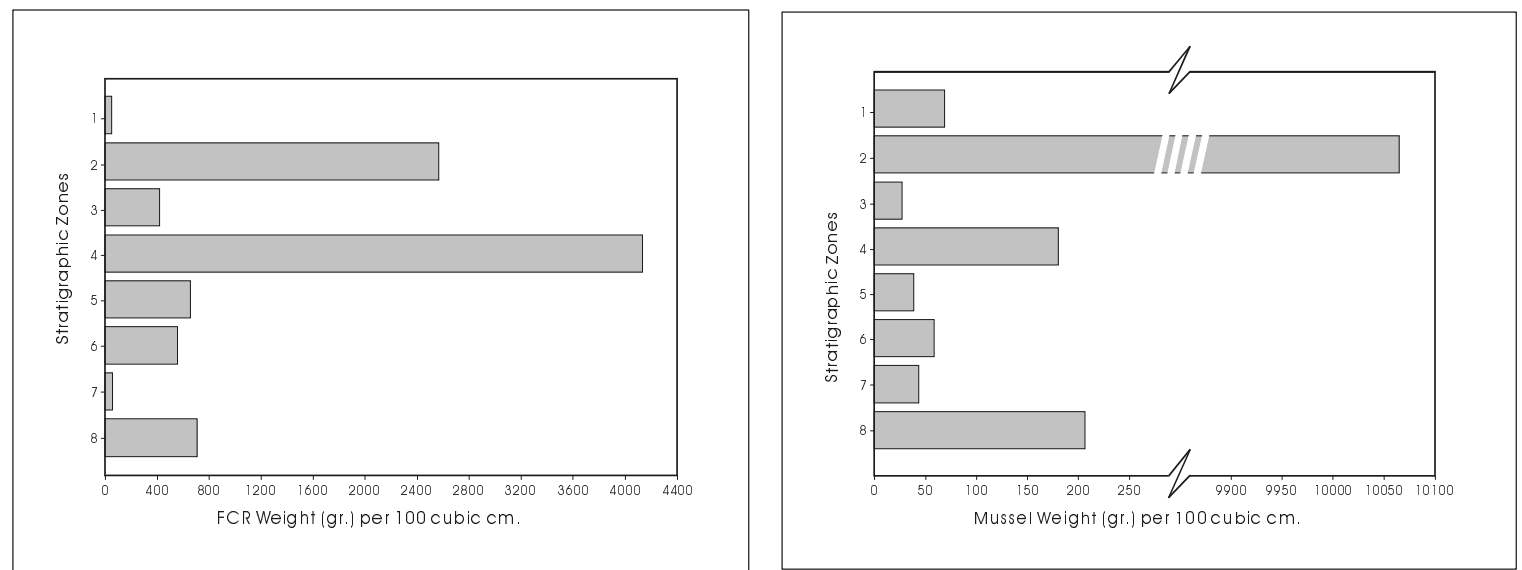

Figure 7-7. Standardized fire-cracked rock (left) and mussel shell (right) weights by zone, Block 2, $41 M M 340$.

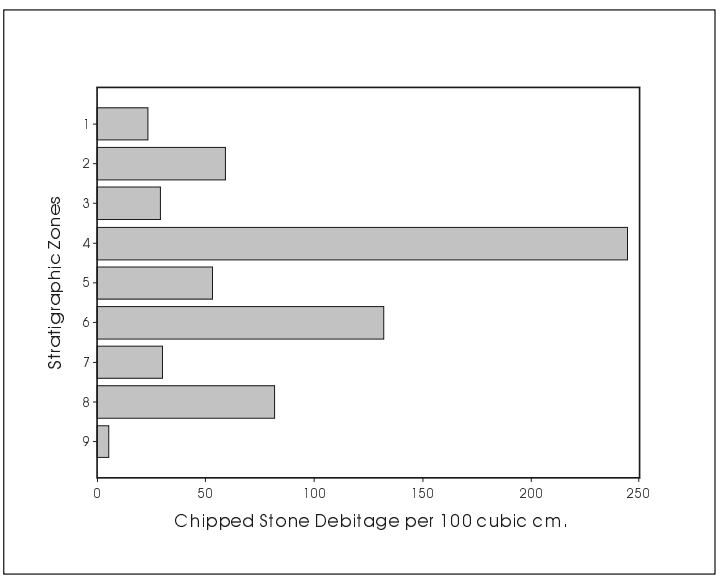

Figure 7-8. Standardized volume of chipped stone recovered by zone in Block 3, 41MM340.

\section{Radiocarbon Dates}

At the suggestion of TxDOT archaeologists, the sampling strategy employed at 41MM340 attempted to bracket each of the primary cultural zones encountered in Blocks 2 and 3 and date the single feature encountered within Block 1. For Blocks 2 and 3, if we assume that a given radiocarbon date provides an accurate date of the sediments in which it is deposited, dating samples from the upper and lower portion of zones would provide a beginning and ending date for that zone.

A total of 16 charcoal samples from 41MM340, chosen in consultation with TxDOT, were submitted to
Beta Analytic, Inc., of Miami, Florida (Beta). All samples were corrected for differing fractionation, and all samples were calibrated using version 3.5 of $\mathrm{OxCal}$ (Ramsey 2000). The sample data and results are provided in Table 7-1. Appendix B presents the sample data sheets.

Samples from Block 1 were recovered from the surface and the base of the feature encountered during the survey phase within BHT 26. Previous Beta radiometric dating for a charcoal sample recovered within this feature by TxDOT provided a corrected date of $2820 \pm 110$ BP (Beta \#128736). Current efforts have produced dates of $2770 \pm 50$ вр (Beta \#141825) and 2880 440 BP (Beta \#141826) from the surface and base of the feature, respectively. The feature, then, is securely dated by these three samples to about 970 B.C.

The sampling strategy of bracketing zones focused on the stratified cultural deposits in Blocks 2 and 3. A total of 14 charcoal samples recovered from these two blocks were submitted for radiometric dating (Table 7-1; Appendix B). For Block 2, carbon samples were extracted from the upper and lower portions of each cultural zone, with the exception of Zone 6, where appropriate samples were not encountered. All samples in Block 2 were taken from Unit C. Figure 7-9 superimposes the vertical provenience of the samples on the profile for Block 2, Unit C. Note that in several cases, the samples represent pooled charcoal from a given level, while in others the vertical provenience 
Table 7-1. Beta Analytic, Inc., results of radiocarbon dating for samples recovered from 41MM340

\begin{tabular}{|c|c|c|c|c|c|c|}
\hline Block & Zone & Aspect & Beta \# & $\begin{array}{c}\text { Corrected } \\
\text { RadiocarbonAge }\end{array}$ & $\begin{array}{c}\text { Calibrated BC } \\
\text { Range at 1 } \\
\text { Sigma }\end{array}$ & $\begin{array}{c}\text { Calibrated BC } \\
\text { Range at 2 } \\
\text { Sigma }\end{array}$ \\
\hline \hline 1 & n/a & upper & 141825 & $2770+/-50 \mathrm{BP}$ & $980-830$ & $1020-810$ \\
\hline 1 & n/a & lower & 141826 & $2880+/-40 \mathrm{BP}$ & $1130-990$ & $1220-920$ \\
\hline \hline 2 & 2 & upper & 141827 & $2380+/-50 \mathrm{BP}$ & $760-390$ & $770-370$ \\
\hline 2 & 2 & lower & 141828 & $2510+/-40 \mathrm{BP}$ & $790-540$ & $800-410$ \\
\hline \hline 2 & 4 & upper & 141829 & $2600+/-50 \mathrm{BP}$ & $830-590$ & $900-540$ \\
\hline 2 & 4 & lower & 141830 & $2480+/-40 \mathrm{BP}$ & $770-510$ & $780-410$ \\
\hline \hline 2 & 8 & upper & 141832 & $2760+/-30 \mathrm{BP}$ & $970-830$ & $1000-820$ \\
\hline 2 & 8 & lower & 141833 & $3070+/-40 \mathrm{BP}$ & $1400-1260$ & $1430-1210$ \\
\hline \hline 3 & 2 & upper & 141834 & $2440+/-40 \mathrm{BP}$ & $760-400$ & $770-400$ \\
\hline 3 & 2 & lower & 141835 & $2420+/-40 \mathrm{BP}$ & $760-400$ & $770-390$ \\
\hline \hline 3 & 4 & upper & 142625 & $2880+/-40 \mathrm{BP}$ & $1130-990$ & $1220-920$ \\
\hline 3 & 4 & lower & 142622 & $2950+/-40 \mathrm{BP}$ & $1260-1050$ & $1300-1010$ \\
\hline \hline 3 & 6 & upper & 141838 & $2800+/-40 \mathrm{BP}$ & $1000-900$ & $1050-830$ \\
\hline 3 & 6 & lower & 142623 & $2910+/-40 \mathrm{BP}$ & $1210-1010$ & $1260-970$ \\
\hline \hline 3 & 8 & upper & 142624 & $3060+/-50 \mathrm{BP}$ & $1400-1260$ & $1430-1130$ \\
\hline 3 & 8 & lower & 141840 & $3050+/-40 \mathrm{BP}$ & $1390-1260$ & $1410-1130$ \\
\hline
\end{tabular}

is restricted to a few centimeters. Though not shown, the horizontal provenience of most samples was confined to small areas within Unit C. For Block 3, a total of 8 samples were submitted (Table 7-1). Unlike the Block 2 samples, where all radiocarbon dates came from Unit C, the samples from Block 3 came from all four units. Three samples were from Unit $C$, two from Unit B, two from Unit A, and one from Unit D. While this may complicate decisions regarding comparisons between dates for a given zone, as well as any estimate of differential sedimentation rates within the block, appropriate samples were not available from a single unit within Block 3.

Examination of the calibrated and corrected ages at either the 1 or 2 sigma ranges will demonstrate that most dates are in good stratigraphic order. However, there are two possible exceptions, one in each block. Beta sample numbers 141830, from the lower deposits in Zone 4 of Block 2, and number 141838 taken from the upper deposits of Zone 6 in Block 3, may be too recent when their overall stratigraphic relationships are considered.
Using the 95.4 percent probability range of the upper and lower dates within the blocks, the radiocarbon dates suggest that the deposits form a relatively tight sequence. Assuming that the radiocarbon dates on the materials actually reflect the time span of the deposits in which the material was found, for Block 2 a minimum span of about 440 years (ca. 1210-770 B.c.) and a maximum span of roughly 1,060 years (ca. 1430370 в.с.) is suggested for the Zone 2 through Zone 8 deposits (Table 7-1). For Block 3, a minimum span of 360 years (ca. 1130-770 B.C.) and a maximum span of 1,010 years (ca. 1410-400 B.C.) is suggested for the Zone 2 through Zone 8 deposits (Table 7-1). Both blocks, then, represent deposits of the same general age, a relatively brief period that straddles the Late Archaic I and Late Archaic II Periods (Johnson 1995:73).

In order to consider the ages of particular zones within a given block, clustering procedures suggested by Ward and Wilson (1978; Wilson and Ward 1981) were used. Initially, all radiocarbon dates within a block were tested using Ward and Wilson's Case II assumptions and the DSPLIT radiocarbon program (Kintigh 


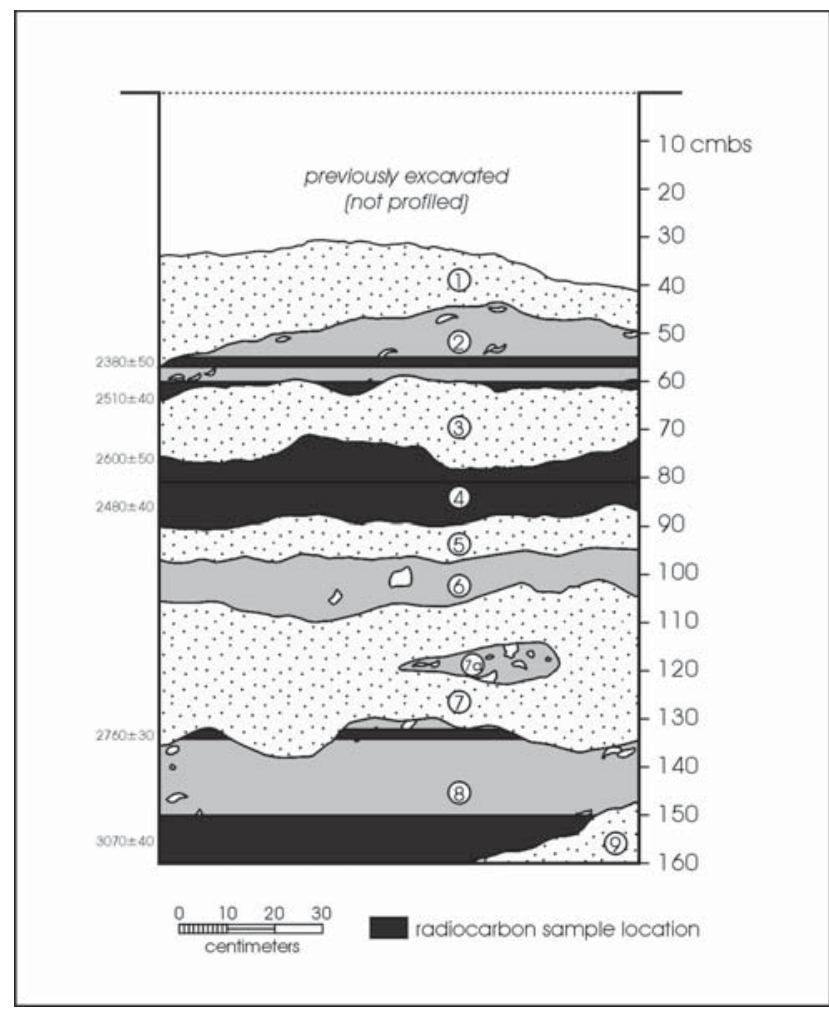

Figure 7-9. The vertical provenience of carbon samples superimposed on the profile for Block 2, Unit C, $41 M M 340$.

1992:83-85). For Block 2, DSPLIT produced three groups of dates that were statistically indistinguishable. The first group consisted of the four upper dates, representing Zones 2 and 4 . The remaining two dates from Zone 8 were statistically different from this group, as well as statistically different from each other. Figure 7-10 presents the probability distributions as well as the 1 and 2 sigma ranges, with the three groups identified.

For the eight dates in Block 3, the DSPLIT procedure also produced three groups. The first group contained the two dates from Zone 2. The second group had four dates, consisting of those in Zones 4 and 6, and the third group contained both dates from Zone 8. Thus, the two dates from Zone 2 are indistinguishable, as are the two dates from Zone 8. In this block, the middle zones, consisting of Zones 4, 5, and 6, appear to be indistinguishable. Figure 7-11 presents the probability distributions for these dates, as well as the 1 and 2 sigma ranges, with the three groups identified.
Reference to Figures 7-10 and 7-11 suggests that the dates from Zones 2 and 4, Block 2 reflect a similar time frame as Zone 2 in Block 3. Similarly, the lower date from Zone 8, Block 2, is similar to the two dates for Zone 8 in Block 3. While the relationship between Zones 4 and 6 in Block 3 and Zone 6 in Block 2 remain unclear, it is likely that they also date to similar time frames. In spite of sampling complications, and the observation that in several cases the zones themselves merge together or are truncated within each block (see Figures 7-2, 7-3), each block represents a similar range of time, and several of the zones within the blocks are temporally indistinguishable.

Table 7-2 presents additional information on radiocarbon dates and accumulation rates from Blocks 2 and 3. Here, we have used the interval estimate provided by the calibration program to calculate the time between adjacent dates within a block. The procedure provides a probability estimate of the number of years represented between the two adjacent dates (Ramsey 2000), and both the 1 sigma and 2 sigma ranges are provided in the table. Note that we have eliminated the two potentially problematic dates in the table, though their inclusion does not dramatically change the overall pattern. Assuming, then, that the remaining radiocarbon dates reflect the time of sediment accumulation, and using the 2 sigma range as an example, the upper and lower dates for Zone 2, Block 2 suggest that there is a 95.4 percent probability that sediments accumulated over a period of between 0 and 370 years. In Zone 8 of Block 2, the upper and lower dates suggest that the accumulation took at least 280 years, and not more than 570 years, at a 95.4 percent probability level. As it is equally probable that, for example, the Zone 8 , Block 2 accumulation occurred in 280 years as it is that the accumulation took 570 years, we also provide the midpoint of the 2 sigma range as a point estimate for the formation. Clearly, a number of other interpretations of these dates are possible, and Appendix B, as well as Tables 7-1 and 7-2, provide the reader with the appropriate data to explore alternative procedures.

Using the cumulative number of years in the midpoint estimate column in Table 7-2 suggests that Block 2 formed in roughly 985 years, and Block 3 formed in 1,275 years, estimates that are close to the maximum 


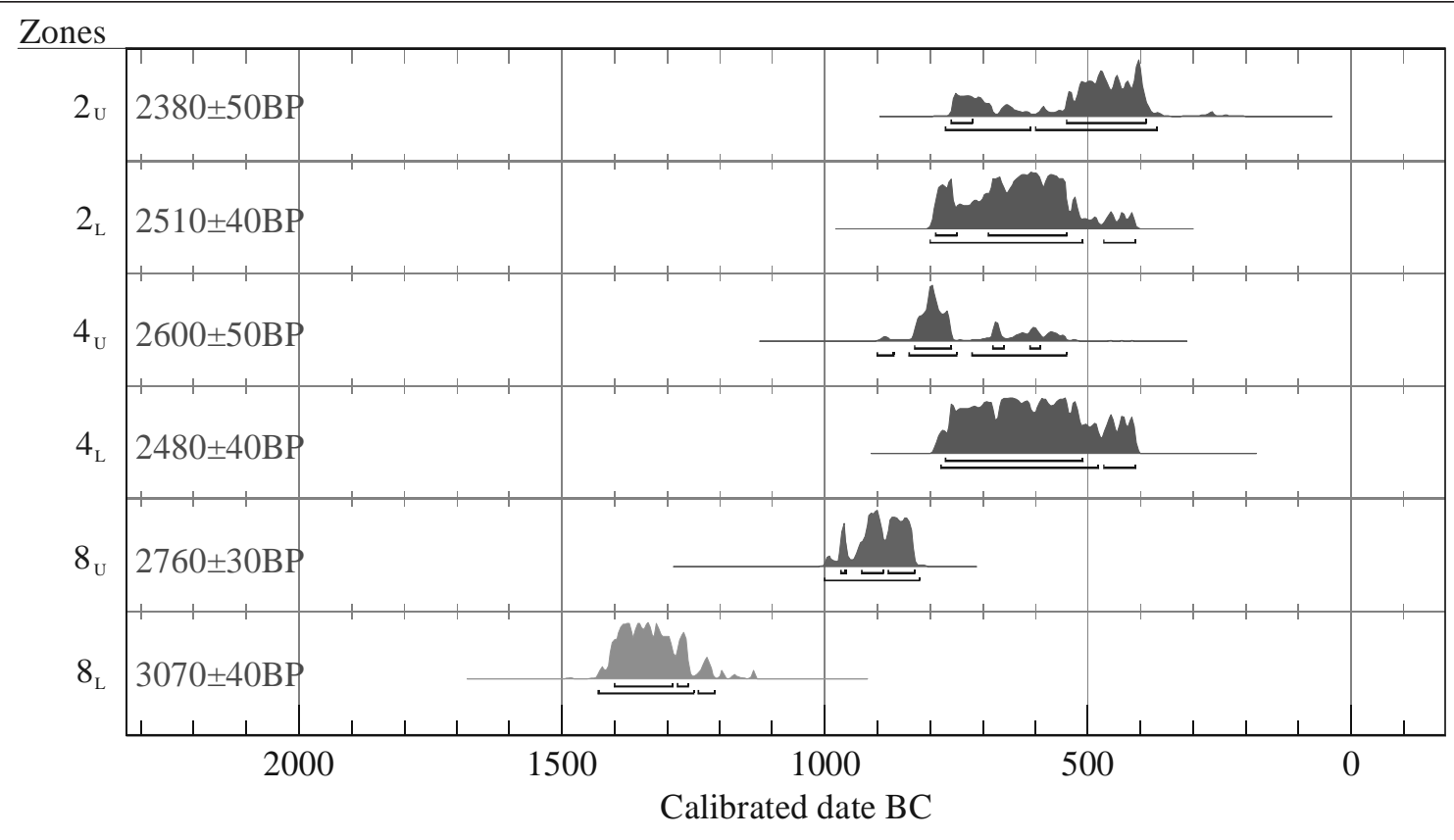

Figure 7-10. Probability distributions of calibrated radiocarbon dates for Block 2, 41MM340. Groups, identified by color, produced by DSPLIT procedure. Atmospheric data from Stuiver et al. (1998); OxCal v3.5 Bronk Ramsey (2000); cub r:4 sd:12 prob usp[strat].

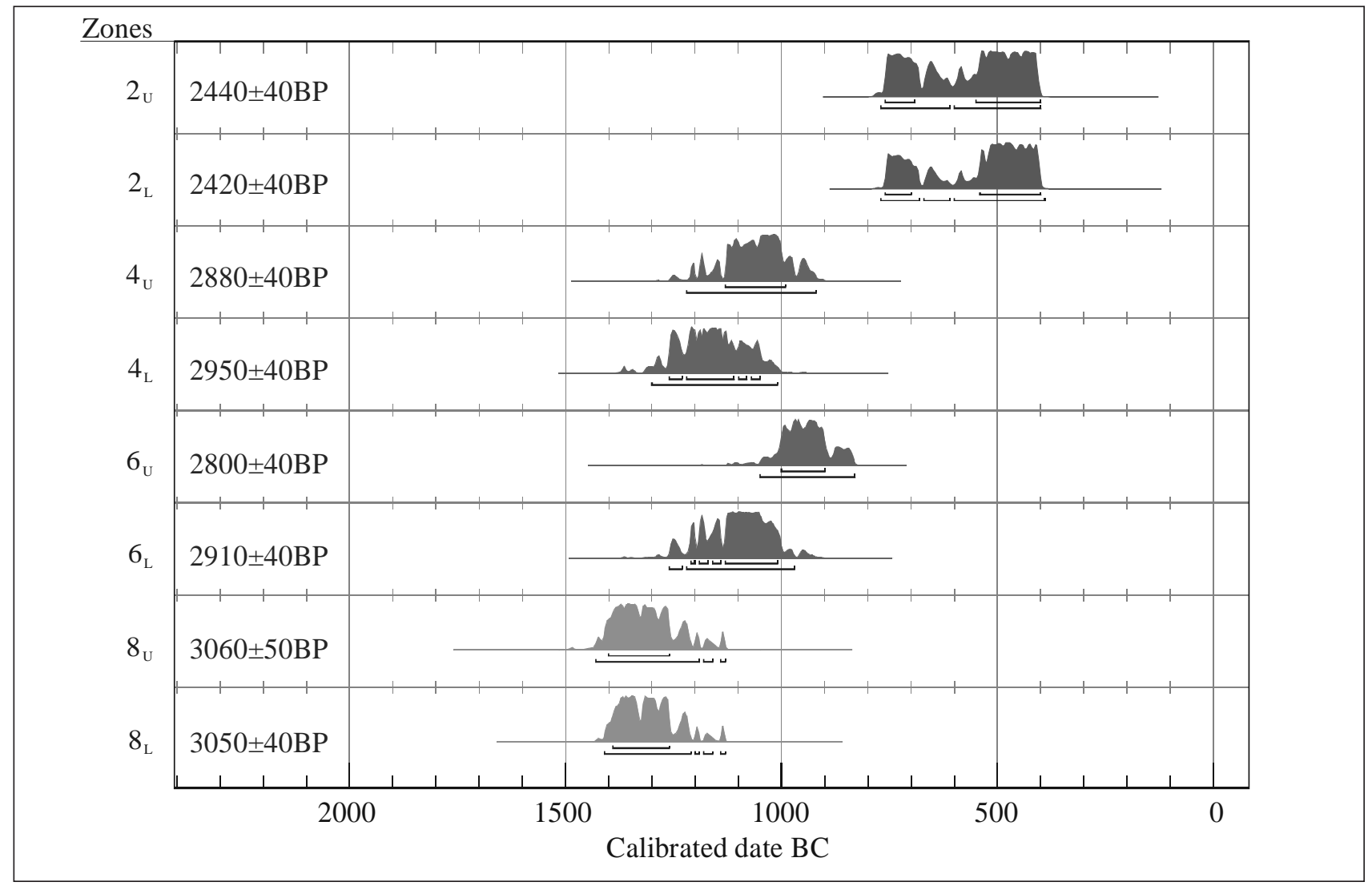

Figure 7-11. Probability distributions of calibrated radiocarbon dates for Block 3, 41MM340. Groups, identified by color, produced by DSPLIT procedure. Atmospheric data from Stuiver et al. (1998); OxCal v3.5 Bronk Ramsey (2000); cub r:4 sd:12 prob usp[strat]. 
Table 7-2. Radiocarbon interval estimates and deposition rates, 41MM340

\begin{tabular}{|c|c|c|c|c|c|c|c|c|}
\hline Block & $\begin{array}{c}{ }^{14} \mathbf{C} \text { date } \\
\text { Location 1 1 }\end{array}$ & $\begin{array}{c}{ }^{\mathbf{1 4}} \mathbf{C} \text { date } \\
\text { Location 2 }\end{array}$ & $\begin{array}{c}\mathbf{1} \text { sigma } \\
\text { interval range }\end{array}$ & $\begin{array}{c}\mathbf{2} \text { sigma } \\
\text { interval range }\end{array}$ & $\begin{array}{c}\text { Midpoint of 2 } \\
\text { sigma interval }\end{array}$ & $\begin{array}{c}\text { Zones } \\
\text { present }\end{array}$ & $\begin{array}{c}\text { cm separating } \\
\text { dates }\end{array}$ & $\begin{array}{c}\text { Accumulation } \\
\text { rate (cm/100 years) }\end{array}$ \\
\hline 2 & $2 \mathrm{u}$ & $2 \mathrm{l}$ & $10-270$ & $0-370$ & 185 & 2 & 7 & 3.78 \\
2 & $2 \mathrm{l}$ & $4 \mathrm{u}$ & $0-260$ & $0-360$ & 180 & 3 & 14 & 7.78 \\
2 & $4 \mathrm{u}$ & $8 \mathrm{u}$ & $30-310$ & $10-380$ & 195 & $4,5,6,7$ & 56 & 28.7 \\
2 & $8 \mathrm{u}$ & $8 \mathrm{l}$ & $360-530$ & $280-570$ & 425 & 8 & 23 & 5.41 \\
\hline 3 & $2 \mathrm{u}$ & $2 \mathrm{l}$ & $0-250$ & $0-310$ & 155 & 2 & 8 & 5.16 \\
3 & $2 \mathrm{l}$ & $4 \mathrm{u}$ & $330-690$ & $200-800$ & 500 & 3 & 8 & 1.6 \\
3 & $4 \mathrm{u}$ & $4 \mathrm{l}$ & $10-190$ & $0-290$ & 145 & 4 & 11 & 7.59 \\
3 & $4 \mathrm{l}$ & 61 & $0-150$ & $0-250$ & 125 & 5,6 & 7 & 5.6 \\
3 & $6 \mathrm{l}$ & $8 \mathrm{u}$ & $110-330$ & $10-390$ & 200 & 7 & 18 & 9 \\
3 & $8 \mathrm{u}$ & $8 \mathrm{l}$ & $0-110$ & $0-200$ & 150 & 8 & 9 & 6 \\
\hline
\end{tabular}

span suggested by comparing the upper and lower radiocarbon dates in each block. For example, we estimated that Block 2 minimally formed between ca. $1210-770$ в.с. (440 years) and $1430-370$ в.c. $(1,060$ years). The cumulative number of years provided by the midpoint summary for this block, 985 years, is consistent with that estimate.

The final two columns of Table 7-2 provide information on the thickness of the deposit between the dates, and the accumulation rate. We use the midpoint of the 2 sigma range as a time estimate, and the elevation difference, in $\mathrm{cm}$, between dates as a thickness estimate. While a number of assumptions are involved, especially with the Block 3 data where the radiocarbon dates come from different units within the block, the accumulation rate provides a gross estimate of deposition rates and, by extension, the probability that deposits potentially represent a palimpsest. That is, high accumulation rates are less likely to be overprinted by multiple occupations, and thereby complicate the interpretive potential of the deposits. An examination of the Block 2 data suggest that the highest accumulation rate occurs in the area represented by Zones 4, 5, 6, and 7, while Zone 2 has the lowest accumulation rate. Within Block 3, the highest accumulation rates are present in Zone 7, with Zone 3 having the lowest accumulation rate.

The radiocarbon dates clearly suggest that the sediments in both Blocks 2 and 3 accumulated over a relatively brief period of time. While a number of interpretations of these data are possible, it is likely that the sediments accumulated in no more than 1,100 years, and it could be the case that the accumulation was much faster. Nevertheless, the varying rates of deposition, hinted at by the data presented in Table 72 , suggest that this rate was not constant.

\section{Amino Acid Racemization Results}

In an effort to clarify the depositional context and integrity of the cultural zones in Blocks 2 and 3 at $41 \mathrm{MM} 340$, a series of snail and mussel shells were selected, in consultation with TxDOT, and submitted for amino acid racemization. Detailed analysis of amino acid racemization values on snail and mussel shell may provide an inexpensive measure pertinent to assessing integrity of deposits (e.g., Ellis et al. 1996; Ellis 1997; Goodfriend 1987; Quigg 1999). Specifically, the racemization of amino acids L-isoleucine to D-alloisoleucine (A/I) in snails and mussels appears to be primarily a function of time. While the racemization rates are complicated by the temperature history of a sample, and while different genera of mollusks probably have different rates of amino acid racemization, radiocarbon dating on snails, primarily Rabdotus, suggests that shells of similar age have similar A/I values (see Ellis et al. 1996). Ellis et al. (1996:191) state that "the relative contemporaneity of artifacts in a deposit will be approximated by the relative contemporaneity of snails buried in the same deposit." That is, the A/I values on shell can be used as a proxy for assessing assemblage integrity. When shells of radically different ages, as measured by different $\mathrm{A} / \mathrm{I}$ values, are present in the same deposit, either burial of the deposits occurred at a slow rate or the deposits 
have been turbated after deposition. In their view, either situation would result in an assemblage of limited integrity and, by extension, limited utility for addressing "behavioral" questions (Ellis et al. 1996).

Given previous work on Rabdotus racemization, samples of this genus would have been ideal. Unfortunately, Rabdotus was not represented from all proveniences in sufficient quantity for analysis (see Appendix G). Consequently, 25 samples of Polygyra mooreana and seven samples of Praticolella berlandieriana were selected from the four primary zones within the two blocks. In addition, 32 samples of mussel shell, consisting of 27 samples of Amblema plicata and five samples of Tritogonia verrucosa, were also submitted. The samples represented both Block 2 and 3 at the site, with the majority $(n=48)$ coming from Block 3. TxDOT supplied CAR with the results of the analyses. These are presented as Appendix I. mussel data are discussed subsequently, all ratios of aspartic acid to glutamic acid are relatively uniform and cluster around a value of 1.1. The lack of outliers in these data suggests that the snails submitted for racemization were not exposed to heat. Finally, note that A/I values for either Polygyra mooreana or Praticolella berlandieriana could not be located in the literature. However, if A/I values from the same genera are consistent, then establishing the exact rate of change is less important than examining the clustering of $\mathrm{A} / \mathrm{I}$ values for a given provenience. If values cluster, then it is likely that they date to the same time period.

Figure 7-12 presents the snail A/I values in Blocks 2 and 3. For comparative purposes, we include the A/I values published by Ellis et al. (1996:201) for Rabdotus from alluvial proveniences on Fort Hood, located about $70 \mathrm{~km}$ to the northwest of the current

Assessing the degree to which a given provenience is disturbed through $\mathrm{A} / \mathrm{I}$ values is minimally dependent on having some idea of the time represented by a given $\mathrm{A} / \mathrm{I}$ value, a variable that is probably genera dependent, some idea of the measurement error in determining the $\mathrm{A} / \mathrm{I}$ value itself, and an understanding of the temperature history of the snails submitted. Goodfriend (2000:405) reports that the analytical error is approximately five percent. In addition, Ellis (personal communication, 2000) suggests that ratios of two other amino acids, aspartic acid and glutamic acid, may provide a measure of the impact of heating in both snails and mussels, as aspartic acid has a lower temperature threshold for racemization. Appendix I presents the ratio of aspartic acid to glutamic acid, as well as the associated $\mathrm{A} /$ I values, for both snails and mussels from the site. While the

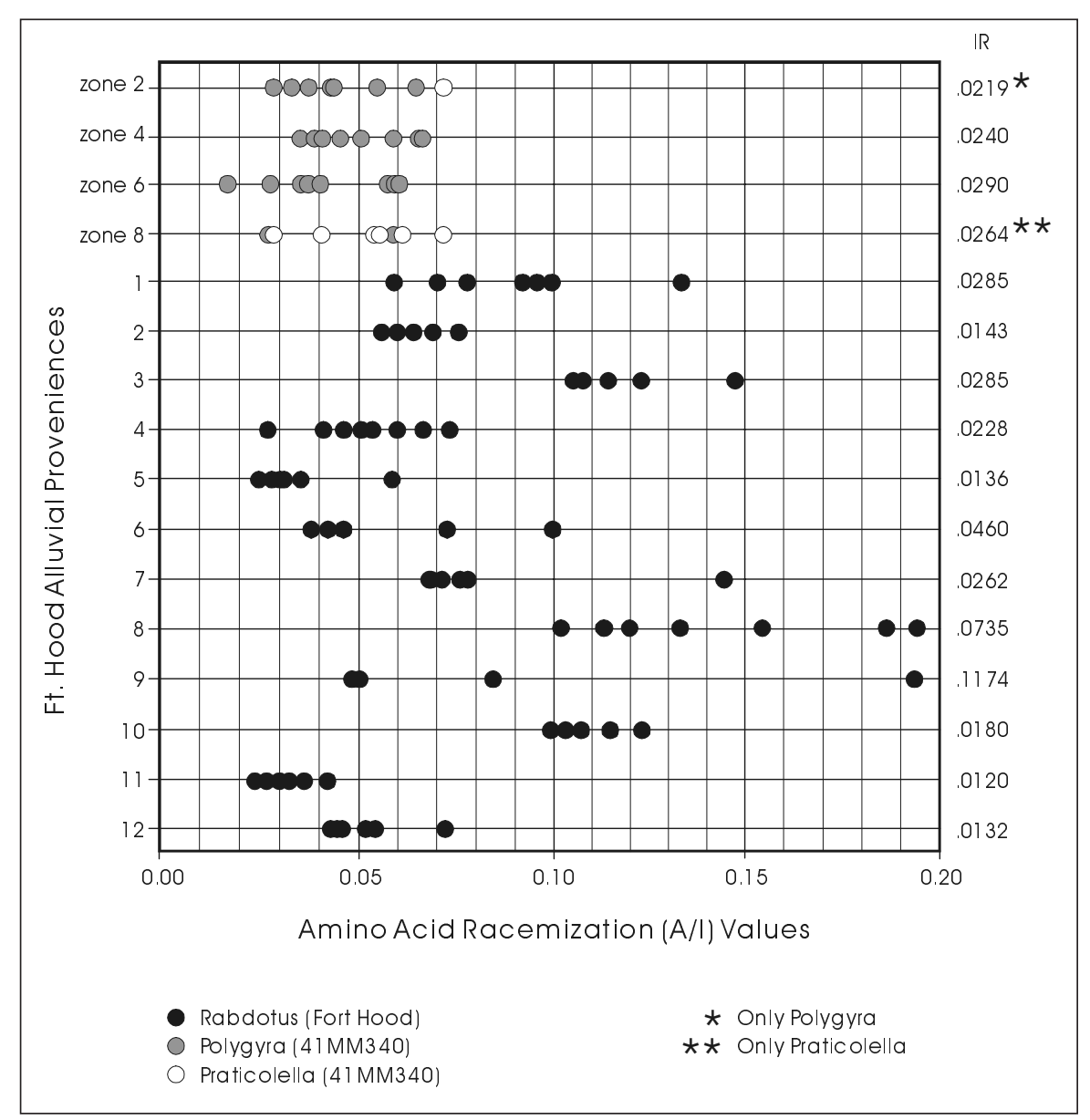

Figure 7-12. Amino acid racemization (A/I) values for Fort Hood proveniences (Ellis 1997) and 41MM340. 
project area. Note that values greater than 0.35 , which Ellis et al. (1996) suggest are indicative of heating, have been eliminated from the comparisons. Values in this range were not present in the 41MM340 snail data, though several of the Fort Hood proveniences had these high values. Examination of the 41MM340 data in the figure will suggest that: 1) variability within a given provenience is small; 2) within each provenience there is a clustering of the $\mathrm{A} / \mathrm{I}$ values from a given species; 3 ) the clustering of values in the 41MM340 data are comparable to the clustering reflected in many of the proveniences from Ft. Hood; and 4) there is no directional change from the Zone 8 data through the Zone 2 data in 41MM340.

Within Zones 2, 4, and 6 at 41MM340, the spread of A/I values on Polygyra mooreana, the species that dominates samples from these zones, are relatively small. This is especially the case in Zones 2 and 4. Zone 6 has two clusters, one consisting of three values centered at 0.028 and a second three-value cluster around an $\mathrm{A} / \mathrm{I}$ value of about 0.06 . The clustering in the upper zones at $41 \mathrm{MM} 340$ are consistent with clusters from several proveniences at Ft. Hood that, on the basis of other data, Ellis et al. (1996) suggested had high integrity. In Zone 8, the six samples of Praticolella berlandieriana have a wider spread, though three of the samples cluster around a value of 0.058 .

To the far right of Figure 7-12 we provide the interquartile range (IR) for the $\mathrm{A} / \mathrm{I}$ ratios for all 16 proveniences. The IR provides a comparable measure for the clustering, identifying the range in which 50 percent of the cases are located. The IR values, which range from a high of .1174 for provenience 9 at Ft. Hood to a low of .0120 for provenience 11 at Ft. Hood, reinforces the visual impressions that most of the 41MM340 cases are tightly clustered. These cases range from .0219 to .0290 .

While values cluster within several of the zones for the 41MM340 data, taken as a whole there is no apparent increase in $\mathrm{A} / \mathrm{I}$ values with decreasing depth for the 23 values of Polygyra mooreana from these upper zones. Nevertheless, based on the radiocarbon results, the bottom of Zone 6 in Block 3 has a radiocarbon date with a 2 sigma midpoint at about 1115 B.c. (1260-970 B.c.) while the top of Zone 2 in Block 2 has a midpoint date of 570 в.с. ( $770-370$ в.с.). It appears, then, that either snails from roughly the same age are being distributed throughout the profile by turbation, or additional factors are impacting the A/I values. Each of these possibilities is considered below.

As noted in Appendix G, the snail assemblage at the site was in excellent condition. The relatively low number of species present and the occurrence of only one species of aquatic gastropod suggest that the snail assemblage was deposited in situ and was not the result of fluvial transport. There is, however, a change in the relative abundance of different species. Rabdotus dealbatus are in abundance in the deepest cultural zones, while Helicina orbiculata dominate the middle and upper zones. Examination of the relative weights of snails by zone within each block (see Figure 7-13) will demonstrate that these changes in species are reflected by changing weights. While a variety of factors may account for the distribution of different species weights seen in the figure, the pattern is not a homogenous distribution that might result from extensive post-depositional turbation. While some lower level of turbation may be consistent with the patterns seen in Figure 7-13, it is unlikely that the lack of directional patterning in $\mathrm{A} / \mathrm{I}$ values can be accounted for solely by reference to extensive post-depositional turbation.

Ellis (personal communication 2001) suggests that the lack of a consistent patterning in the deposits may be related to temperature differences. As noted above, temperature can have an impact on the $\mathrm{A} / \mathrm{I}$ ratios, with exposure to high temperatures resulting in higher rates of racemization, and higher $\mathrm{A} / \mathrm{I}$ values, and lower temperatures resulting in lower $\mathrm{A} / \mathrm{I}$ values. Thus, if temperatures within a given level were uniformly reduced, $\mathrm{A} / \mathrm{I}$ values would still cluster, but be out of place relative to other levels. Examination of Figure 7-12 suggests that this is precisely the case with the Zone 6 samples, where there is reasonably good clustering of the values, but a lower overall value relative to Zones 4 and 2. Possible reasons for the reduced temperature pattern may include fluctuations in the water table or changes in surface hydrology resulting in saturation of the soil, either of which could result in lower overall temperatures. However, we have no detailed information on either of these potential causes operating at 41MM340. 
In addition to the snail shells, 32 samples of mussel shell, consisting of 27 samples of Amblema plicata and five samples of Tritogonia verrucosa, were also submitted from 41MM340 for analysis (see Appen$\operatorname{dix} \mathrm{I}$ ). As with the snail data discussed above, the ratios of L-isoleucine to D-alloisoleucine (A/I) were monitored. The assumptions are identical to those for the snail data. However, previous work on A/I values of mussels has suggested that heating, noted as a potential problem in snails, is common in these larger mollusks. In an analysis of Amblema plicata Ellis (1997) has demonstrated that a substantial number of samples from a burned rock midden have A/I values that are in excess of 0.20 , values that are likely the result of heating.
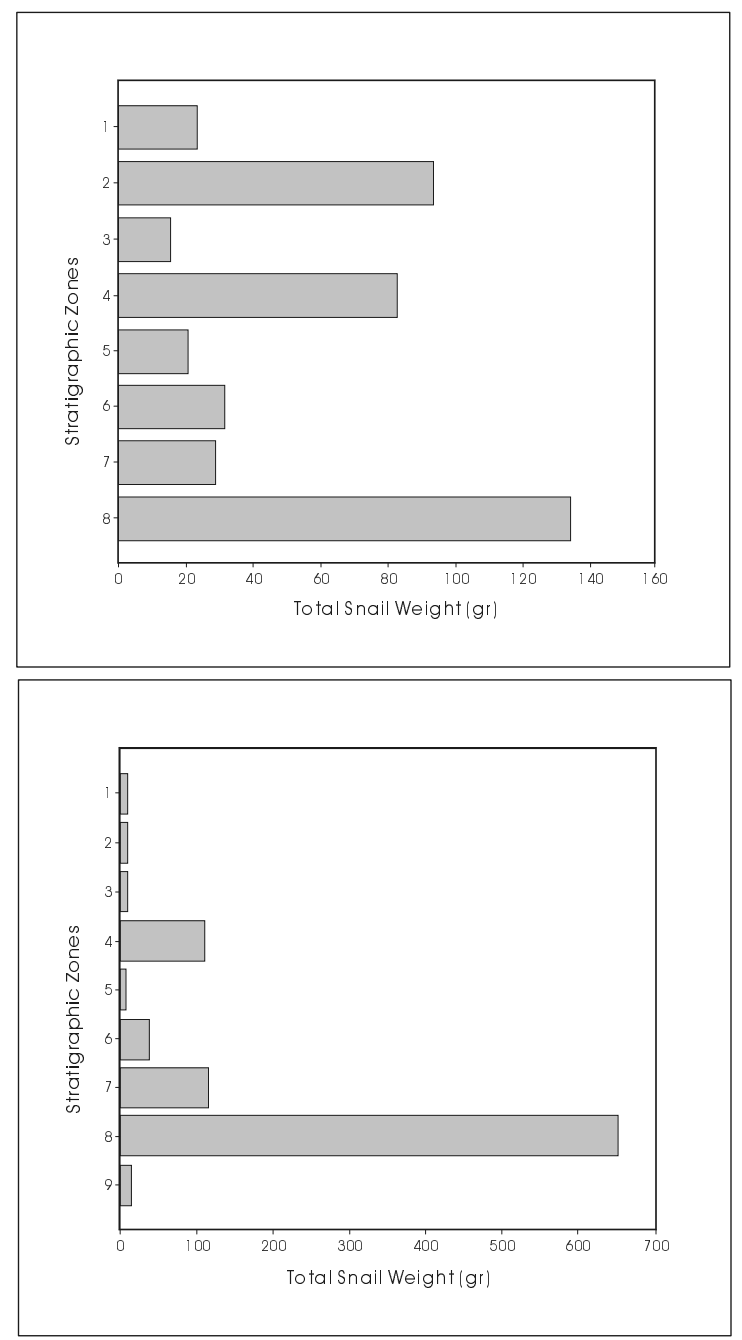

Figure 7-13. Total snail weight (gr.) by zone for Block 2 (top) and Block 3 (bottom) at $41 M M 340$.
As noted above, the ratio of aspartic acid to glutamic acid may provide a measure of the impact of heating in snails and mussels. Reference to the mussel shell data in Appendix I will demonstrate that in several cases, extremely high A/I ratios are associated with low values in the ratio of aspartic acid to glutamic acid. Most of the lower aspartic acid to glutamic acid cases have A/I values in excess of 0.2. Given Ellis' (1997) previous results, we will eliminate those seven cases with $\mathrm{A} / \mathrm{I}$ values greater than 0.2 from the analysis (see Appendix I). However, it may still be the case that some unknown component of the remaining mussel A/I values have been altered by exposure to heat, a factor that would both inflate individual values and change the overall distribution.

Figure 7-14 presents the A/I ratios for the remaining 25 samples. Note that, as with the snail data discussed earlier, in most cases the mussels are tightly clustered. Only a single value, in Zone 8, is an obvious outlier relative to the rest of the distribution. In addition, as with the snail data, the $\mathrm{A} / \mathrm{I}$ values in the mussels show no overall trend in increasing values with depths. While a trend is apparent in the Block 3 data sets consisting of Zones 8, 6, and 4, the Zone 2 data, that comes from Block 2 at 41MM340, do not follow the trend. As with the snail data, a variety of factors may

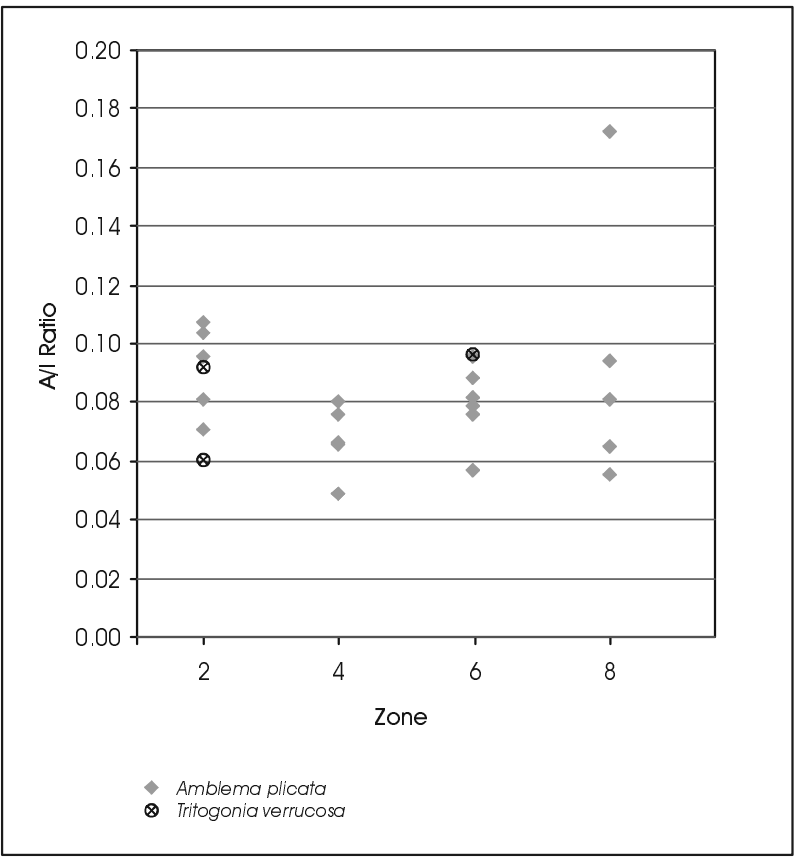

Figure 7-14. A/Iratios (less than 0.2) for mussel shells by zone at $41 M M 340$. 
account for these differences, but differential heating is the most likely candidate for both the extreme outlier value in Zone 8 , as well as the ambiguity of the overall pattern of $\mathrm{A} / \mathrm{I}$ values on mussels.

\section{Temporal Diagnostic Chipped Stone Tools}

A total of 14 projectile points were identified in the 41MM340 collection. In addition, four Erath bifaces recovered from excavation can be used to provide broad temporal information on specific archaeological components within the site (Table 7-3).

Of the fourteen dart points eight can be typed, two are untyped, and the remaining four are untypeable fragments. The eight typed specimens consist of two Gary, a Lange, a Morrill, a Marshall, two Castroville, and an Ellis (Figure 7-15). One of the two Gary points (Figure 7-15a) is made of brown, relatively poor quality, petrified wood. The second Gary is made of naturally pinkish-red chert (Figure 7-15b) that is a common component of upland gravel concentrations along the western edge of East Texas. The type is a typical East
Texas form. The Lange point has a slightly expanding stem and a convex base (Figure 7-15c). It is relatively thick and roughly shaped. Lange points are typically common in Central Texas. The Morrill point has a parallel to slightly barrel-shaped stem and a straight base (Figure 7-15d). It is generally thought of as an East Texas point type (Suhm and Jelks 1962:223). The Marshall point has a short, slightly expanding stem, and a concave base (Figure 7-15e). Its short barbs are slightly downward pointing. It is a point type common to Central Texas and the Edwards Plateau. The two Castroville points have broad expanding stems and straight bases (Figure 7-15f). This type is also most frequent on the Edwards Plateau and in Central Texas. The Ellis point, the final typed specimen, has an expanding stem, convex base, and short downward pointing barbs (Figure 7-15g). It is made of light gray chert similar to that obtained in the vicinity of Georgetown, Texas. The type is common in both East and Central Texas.

A complete dart point with a narrow parallel stem and a straight base cannot be assigned to a specific type (Figure 7-15h). The longitudinally asymmetrical blade

Table 7-3. List of potential chronologically diagnostic artifacts recovered from 41MM340

\begin{tabular}{|c|c|c|c|c|c|c|c|}
\hline Lot & Block & Unit & Zone & Level & Depth & Artifact Category & Comments \\
\hline 42 & 1 & A & $\mathrm{n} / \mathrm{a}$ & 6 & $50-60 \mathrm{cmbs}$ & Morrill Dart Point & Complete; Figure 7-15d \\
\hline 97 & 1 & A & $\mathrm{n} / \mathrm{a}$ & 10 & $90-100 \mathrm{cmbs}$ & Untyped Parallel Stemmed Straight Based & $\begin{array}{l}\text { Stem fragment; Bulverde-like but } \\
\text { shorter than typical stem }\end{array}$ \\
\hline 122 & 1 & $\mathrm{C}$ & $\mathrm{n} / \mathrm{a}$ & 10 & $90-100 \mathrm{cmbs}$ & Lange Dart Point & Complete; Figure 7-15c \\
\hline 87 & 2 & $\mathrm{D}$ & 2 & 1 & $@ 56 \mathrm{cmbs}$ & Castroville Dart Point & Proximal fragment; Figure 7-15f \\
\hline 220 & 1 & D & $\mathrm{n} / \mathrm{a}$ & 12 & $110-120 \mathrm{cmbs}$ & Castroville Dart Point & Stem fragment \\
\hline 224 & 2 & $\mathrm{C}$ & 7 & 3 & $@ 110 \mathrm{cmbs}$ & Marshall Dart Point & Complete; Figure 7-15e \\
\hline 294 & 2 & $\mathrm{~B}$ & 8 & 2 & $140-150 \mathrm{cmbs}$ & $\begin{array}{r}\text { Untyped Narrow Parallel Stemmed Straight } \\
\text { Based } \\
\end{array}$ & $\begin{array}{l}\text { Complete; may be reworked Montell; } \\
\text { Figure } 7-15 \mathrm{~h}\end{array}$ \\
\hline 66 & 3 & A & 2 & 2 & $50-60 \mathrm{cmbs}$ & Ellis Dart Point & $\begin{array}{l}\text { Complete; made on "Georgetown flint" } \\
\text { Figure } 7-15 \mathrm{~g}\end{array}$ \\
\hline 89 & 3 & $\mathrm{D}$ & 3 & 3 & $60-70 \mathrm{cmbs}$ & Gary Dart Point & Proximal fragment; Figure 7-15a \\
\hline 212 & 2 & $\mathrm{D}$ & 6 & 2 & $100-110 \mathrm{cmbs}$ & Gary Dart Point & Proximal fragment; Figure $7-15 \mathrm{~b}$ \\
\hline $152-1$ & 3 & A & 4 & 2 & $84-94 \mathrm{cmbs}$ & Untypable Stem Fragment & Small stem fragment \\
\hline $89-1$ & 3 & $\mathrm{D}$ & 2 & 3 & $20-30 \mathrm{cmbs}$ & Untypeable Dart Point Distal Fragment & Manufacture broken preform \\
\hline $157-1$ & 1 & $\mathrm{~B}$ & $\mathrm{n} / \mathrm{a}$ & 11 & $100-110 \mathrm{cmbs}$ & Untypeable Dart Point Distal Fragment & Use broken \\
\hline $196-1$ & 1 & $\mathrm{D}$ & $\mathrm{n} / \mathrm{a}$ & 11 & $100-110 \mathrm{cmbs}$ & Untypeable Dart Point Distal Fragment & Use broken \\
\hline $111-1$ & 2 & $\mathrm{~B}$ & 4 & 1 & $@ 67 \mathrm{cmbs}$ & Large Erath Biface & Complete; Figure 7-15i \\
\hline $220-2$ & 1 & $\mathrm{D}$ & $\mathrm{n} / \mathrm{a}$ & 12 & $110-120 \mathrm{cmbs}$ & Erath Biface Preform & Overshot distal fragment \\
\hline $137-2$ & 3 & $\mathrm{D}$ & 4 & 2 & $85-89 \mathrm{cmbs}$ & Erath Biface Fragment & $\begin{array}{l}\text { Distal fragment with evidence of } \\
\text { rejuvenation }\end{array}$ \\
\hline $137-1$ & 3 & $\mathrm{D}$ & 4 & 2 & @92 cmbs & Small Erath Biface & Complete \\
\hline
\end{tabular}




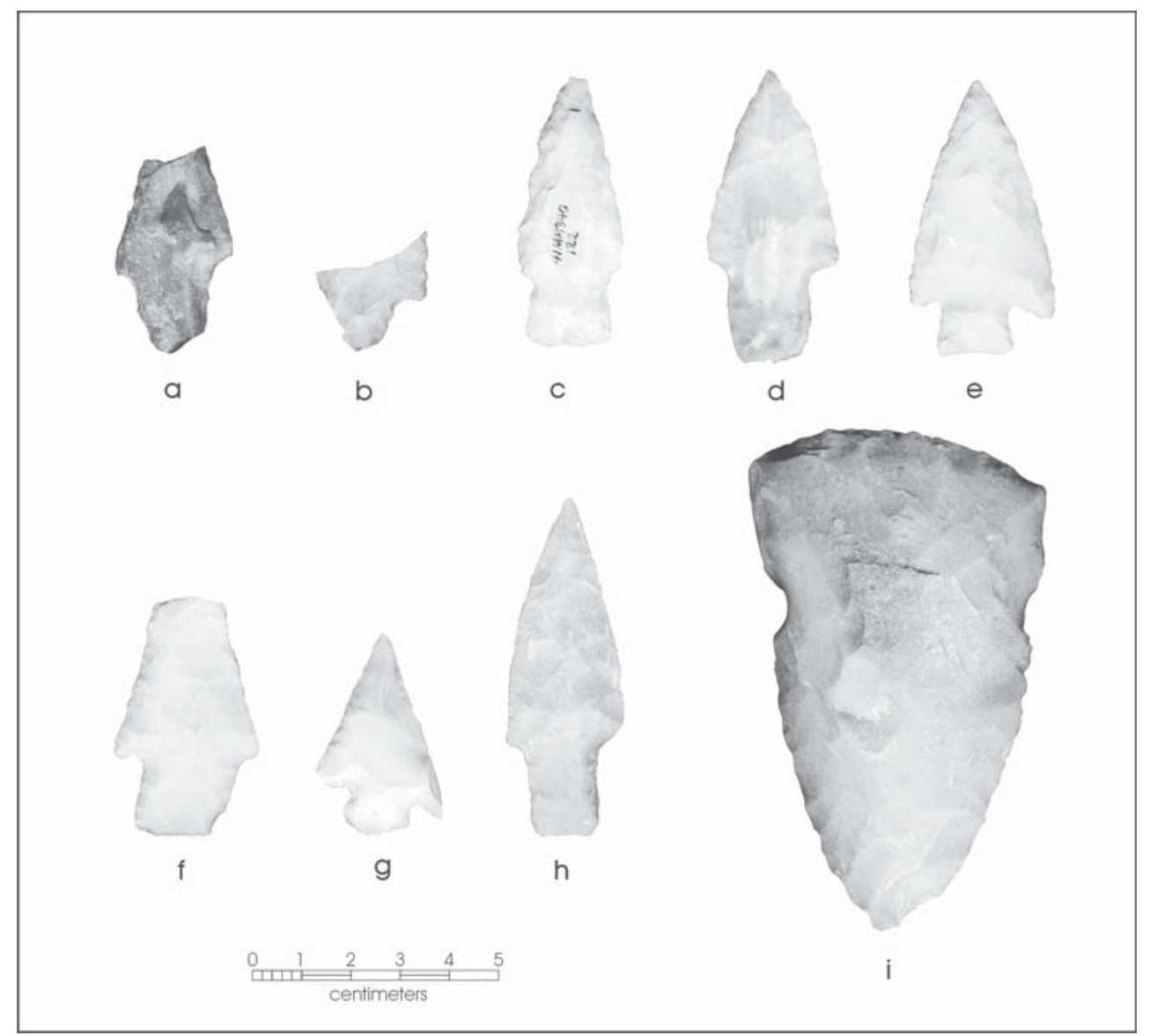

Figure 7-15. Dart points and Erath biface recovered from 41MM340. a, b) Gary; c) Lange; d) Morrill; e) Marshall; f) Castroville; g) Ellis; h) untyped parallel stemmed point; i) Erath biface.

and the reworking along one edge of the stem and blade suggest that the point might be a reworked Montell specimen. However, the stem is somewhat wider than the split stem of a typical Montell point. A short untyped rectangular stem fragment is reminiscent of Bulverde points, although it is somewhat shorter than typical for the type. The remaining projectile point fragments are untypeable distal $(n=3)$, and proximal $(n=1)$ fragments.

The relative stratigraphic position of the eight typed specimens is somewhat confusing with Gary points ranging between $60-70 \mathrm{~cm}$ bs in Block 3 and 100-110 $\mathrm{cm}$ bs in Block 2, and the two Castroville points ranging from $56 \mathrm{~cm}$ bs in Block 2 to $110-120 \mathrm{~cm}$ bs in Block 1. On the other hand, the Ellis point that tends to be assigned to the later part of Late Archaic II is at $50-60 \mathrm{~cm}$ bs in Block 3, and the Marshall, that tends to precede the smaller dart points of the Late Archaic
II (see Johnson 1995:Figure 80), is from $110 \mathrm{~cm}$ bs, in Block 2. Regardless of their specific and relative stratigraphic positions, based on their previously known chronological affiliation, the six types are consistent with the range of site occupations as reflected by the ${ }^{14} \mathrm{C}$ dates (i.e., later half of the Late Archaic II through the early half of the Late Archaic I).

The four Erath bifaces from the site can be assigned to the Late Archaic period (see Story and Shafer 1965:45). Two of the four specimens are complete. The larger of the two complete Erath bifaces (Figure 7-15i) has a morphology not unlike that of the Clear Fork gouges (Story and Shafer 1965; Prewitt 1982:Figure 36). Were it not for the two notches on the lateral edges of the specimen near the working edge, it would have been classified as a Clear Fork tool. The smaller complete specimen has a similar morphology with deep notches in the vicinity of the working edge and 
one concave lateral margin. The four Erath bifaces are distributed between $67-120 \mathrm{~cm}$ bs, with three of the four coming from between $67-92 \mathrm{~cm}$ bs.

The small collection of formal tools exhibits a mix of artifacts typically thought to be more closely affiliated with Central Texas (e.g., Castroville, Marshall, Ellis) or East Texas (e.g., Gary, Erath bifaces). Interestingly, with the exception of the Ellis point, artifacts that date roughly to the latter part of the Late Archaic I seem to show a stronger affiliation with East Texas than artifacts that date to the early part of the Late Archaic I and later portion of Late Archaic II. This pattern may signal some interesting regional changes in mobility and resource procurement. The chronological divisions referred to here accord with Johnson and Goode (1994).

\section{Feature Descriptions}

A total of seven cultural features were identified and excavated at $41 \mathrm{MM} 340$. Six features were newly recorded and one (Feature 6) was previously recorded during the survey phase. Five of the encountered features (Nos. 2, 4, 5, 6, and 7) can be classified as true, rock-lined basin hearths with associated fire-cracked rock, charcoal, and other heat-altered remnants (Table 7-4). A single feature (No. 3) is interpreted as a refuse pit. More detailed descriptions of the individual features are discussed below.

\section{Feature 1}

Feature 1 is a relatively large $(>50 \mathrm{~cm})$ slab of friable sandstone with no associated artifacts. This anomaly was encountered in the northwestern quadrant of Block 3, Excavation Unit (XU) A at $40 \mathrm{~cm}$ (16 in.) below ground surface, approximately $15 \mathrm{~cm}$ (6 in.) above the underlying rich cultural zone. The slab is encased with remnants of the deteriorated exterior surface exfoliated into the surrounding soil, forming a tan, sandy sediment. Since it is contained within the upper zone of relatively recent fill and appears to be unmodified, it is probably non-cultural in origin.

\section{Feature 2}

Feature 2 is a rock-lined basin hearth and consists of a roughly circular concentration of fire-cracked rock with associated fired clay, charcoal, freshwater mussel shell, and lithic debitage. The feature was encountered within Zone 4 of Block 3, XUC and XUD at approximately $83 \mathrm{~cm}$ (33 in.) below ground surface (Figure 7-16). The cobbles comprising the exterior portion of the feature averaged approximately $10 \mathrm{~cm}(4$ in.) in diameter. The concentration measures approximately $85 \mathrm{~cm}$ (34 in.) in diameter and appeared to exhibit a slight vertical concavity.

\section{Feature 3}

Feature 3, a refuse pit, was encountered during the reexcavation of backhoe trench (BHT) 26. The feature occurs at approximately $110 \mathrm{~cm}$ bs within the upper aspect of a weakly developed paleosol. The pit is conical in shape, with the upper rim measuring approximately $60 \mathrm{~cm}$ in diameter and the base approximately $20 \mathrm{~cm}$ in diameter. The overall depth of the pit is 25 $\mathrm{cm}$. The rich, midden-stained soil of the refuse pit included burned bone, chipped stone, mussel shell, and small fragments of burned rock. The refuse pit, Feature 6 (see below), and a nutting stone (catalog number 157-2) were all encountered within a less than 70 $\mathrm{cm}$ radius contained in the upper aspect of the paleosol. Excavation of the three arbitrary levels in which these features occurred resulted in the recovery of roughly

Table 7-4. Features encountered during manual excavation at 41MM340

\begin{tabular}{|c|c|c|c|l|}
\hline Feature & Block & Unit & Elevation & \multicolumn{1}{c|}{ Type } \\
\hline 1 & 3 & A & $33-42 \mathrm{cmbs}$ & Large, unmodified sandstone slab. Probable non-feature. \\
\hline 2 & 3 & C,D & $83-89 \mathrm{cmbs}$ & Rock-lined hearth. \\
\hline 3 & 1 & B & $100-135 \mathrm{cmbs}$ & Unlined pit feature. \\
\hline 4 & 2 & C & $78-86 \mathrm{cmbs}$ & Rock-lined hearth. \\
\hline 5 & 3 & A & $85-94 \mathrm{cmbs}$ & Rock-lined hearth. \\
\hline 6 & 1 & A & $113-125 \mathrm{cmbs}$ & Rock-lined hearth. \\
\hline 7 & 3 & A,B,C,D & $92-111 \mathrm{cmbs}$ & Rock-lined hearth. \\
\hline
\end{tabular}


one third of the artifact assemblage for the entire block, indicating an intense use/activity area.

\section{Feature 4}

Feature 4 is a rock-lined basin hearth and consists of an irregular, oblong concentration of fire-cracked rock with associated charcoal, sparse freshwater mussel shell, and moderate to abundant lithic debitage. The feature was encountered within Zone 4 of Block 2, XUC at approximately $78 \mathrm{~cm}$ (31 in.) below ground surface. A majority of the cobbles contained within the hearth were tabular burned sandstone $5-10 \mathrm{~cm}$ in diameter. Also present within the feature were several siliceous pebbles, averaging approximately $3 \mathrm{~cm}$ in diameter (Figure 7-17). Some of these pebbles appeared to have been exposed to heat, suggesting they may have been utilized as boiling stones. The concentration measures approximately $40 \mathrm{~cm}$ (16 in.) wide and $50 \mathrm{~cm}$ (20 in.) long and appeared to exhibit a slight vertical concavity.

\section{Feature 5}

Feature 5 is a large rock-lined basin hearth and consists of an ovate concentration of fire-cracked rock with associated charcoal. The feature was encountered within Zone 4 of Block 3, XUA at approximately 85 $\mathrm{cm}$ (33 in.) below ground surface. A small portion (less than 10 percent) of the feature appears to extend north and west of XUA and was not excavated. The concentration measures approximately $55 \mathrm{~cm}$ (22 in.) at the widest point and $81 \mathrm{~cm}$ (32 in.) at the longest point and appeared to exhibit a slight vertical concavity.

\section{Feature 6}

Feature 6 was originally recorded during the TxDOT survey phase in BHT 26 as a burned rock feature (Ahr and Abbott 1999:11). Re-excavation of the backhoe trench allowed relocation of Feature 6 as well as the associated Feature 3 (see above). Feature 6 is a small rock-lined basin hearth consisting of a circular concentration of fire-cracked rock. Abundant charcoal was encountered in the matrix immediately beneath the concentration of burned rocks. The feature was encountered in Block 1, XUA at approximately $113 \mathrm{~cm}$ (44 in.) below ground surface. The extant portion of the feature suggests an original diameter of approximately $40 \mathrm{~cm}$ (16 in.) and a depth of $12 \mathrm{~cm}(5 \mathrm{in}$.).

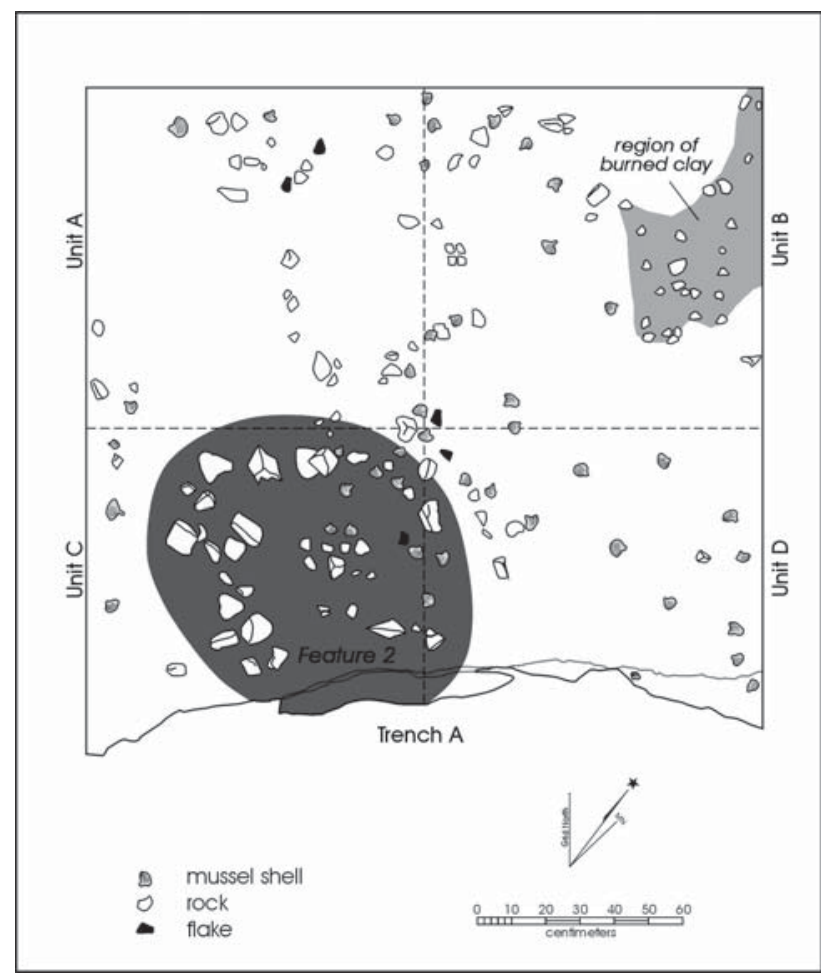

Figure 7-16. Feature 2, Block 3, 41MM340.

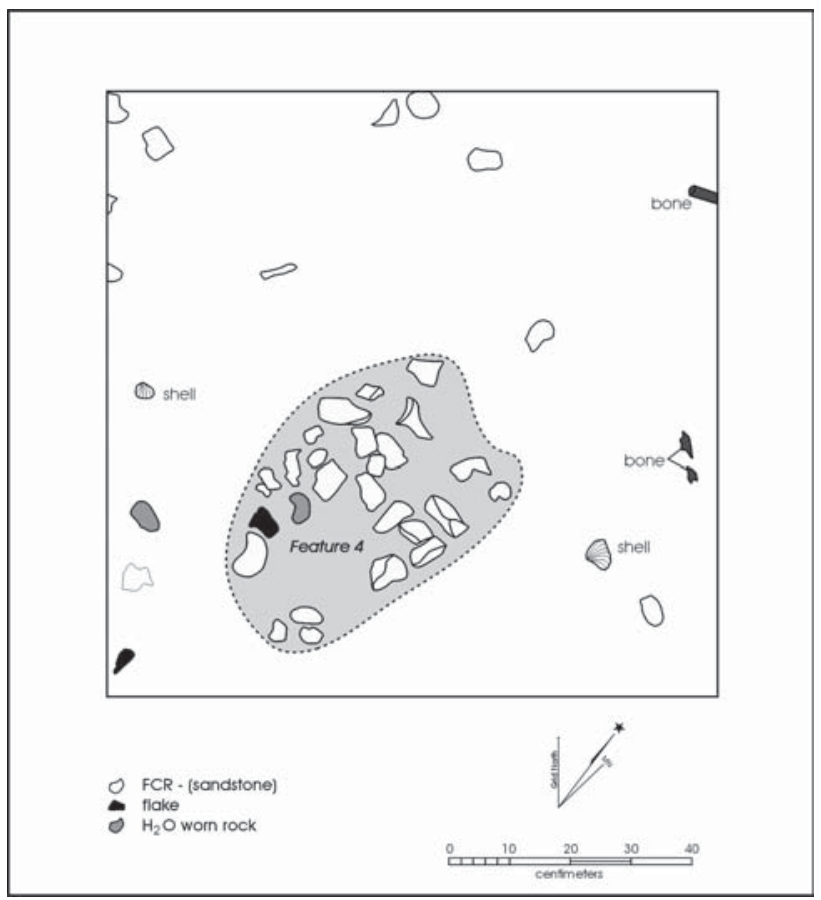

Figure 7-17. Feature 4, Block 2, Unit C, 41MM340. 


\section{Feature 7}

Feature 7 is a rock-lined basin hearth and consists of an irregular concentration of fire-cracked rock with associated charcoal, and sparse freshwater mussel shell. The feature was encountered within Zone 6 of Block 3, XUA, XUB, XUC, and XUD at approximately $92 \mathrm{~cm}$ (36 in.) below ground surface. The cobbles comprising the exterior portion of the feature averaged approximately $7 \mathrm{~cm}$ (3 in.) in diameter, with smaller cobbles and pebbles located in the interior portion of the hearth. The concentration measures approximately $65 \mathrm{~cm}$ (26 in.) wide and $75 \mathrm{~cm}$ (30 in.) long and exhibited vertical concavity of approximately $19 \mathrm{~cm}$ (7 in.).

\section{Artifact Distribution}

Tables 7-5 through 7-7 present the distribution of artifacts and ecofacts recovered from the three blocks excavated at $41 \mathrm{MM} 340$. In addition to the raw data counts for each category, volumetric calculations are provided for the eight zones in Block 2 (Table 7-8) and the nine zones in Block 3 (Table 7-9). These volumetric tables provide a standardized comparison of selected artifact and ecofact classes for the zones encountered, given the vertical undulations and variability of zone thickness. The data in Tables 7-8 and 7-9 are adjusted for a volume of 100 cubic $\mathrm{cm}$. Many of these distributions have been presented previously (see Figures 7-5 through 7-8, Figure 7-13). An examination of the other categories in Table 7-5 for Block 1 will reinforce the pattern of at least two distinct modes suggested by the chipped stone distribution presented in Figure 7-5. In addition, the distribution of all classes of material in Blocks 2 and 3 (see Tables 7-8, 7-9) support the presence of multiple zones in each of the two blocks.

\section{Debitage Analysis}

All unmodified debitage recovered from the three blocks at $41 \mathrm{MM} 340$ has been categorized in terms of corticate (i.e., primary and secondary) and decorticate (tertiary) specimens. A comparison of relative proportions of these two categories can identify differences in stages of reduction either between or within blocks and cultural zones.

Table 7-5. Vertical Distribution of Artifacts and Ecofacts Recovered from Block 1, 41MM340

\begin{tabular}{|c|c|c|c|c|c|c|c|c|c|c|c|}
\hline \multirow[t]{2}{*}{ Level } & \multirow{2}{*}{$\begin{array}{c}\begin{array}{c}\text { Chipped } \\
\text { Stone }\end{array} \\
\mathrm{N} \\
\end{array}$} & \multicolumn{2}{|r|}{ FCR } & \multicolumn{2}{|c|}{$\begin{array}{c}\text { Mussel Shell } \\
\text { Umbo }\end{array}$} & \multirow{2}{*}{$\begin{array}{c}\begin{array}{c}\text { Mussel Shell } \\
\text { Fragments }\end{array} \\
\mathrm{Wt} \text { (gr.) } \\
\end{array}$} & \multicolumn{2}{|c|}{ Snail Shell } & \multirow{2}{*}{$\begin{array}{c}\text { Snail Shell } \\
\text { Fragments } \\
\mathrm{Wt} \text { (gr.) } \\
\end{array}$} & \multicolumn{2}{|c|}{ Bone } \\
\hline & & $\mathrm{N}$ & Wt (gr.) & $\mathrm{N}$ & Wt (gr.) & & $\mathrm{N}$ & Wt (gr.) & & $\mathrm{N}$ & Wt (gr.) \\
\hline 01 & 2 & 3 & 22.77 & 2 & 6.5 & 0.69 & 0 & 0 & 0 & 0 & 0 \\
\hline 02 & 2 & 3 & 0.73 & 0 & 0 & 0 & 2 & 0.3 & 0 & 62 & 28.82 \\
\hline 03 & 6 & 5 & 112.4 & 1 & 1 & 1 & 46 & 9 & 0 & 2 & 0.34 \\
\hline 04 & 7 & 0 & 0 & 0 & 0 & 0 & 23 & 5 & 0 & 0 & 0 \\
\hline 05 & 16 & 9 & 77.94 & 5 & 13.6 & 223.4 & 350 & 73.3 & 1 & 6 & 2.32 \\
\hline 06 & 83 & 37 & 430.21 & 27 & 35.4 & 11.39 & 588 & 104 & 189.98 & 11 & 12.21 \\
\hline 07 & 417 & 322 & 1289.92 & 89 & 209.7 & 33.53 & 356 & 61.8 & 15.65 & 55 & 15.22 \\
\hline 08 & 159 & 101 & 1492.65 & 26 & 40.1 & 8.12 & 477 & 98.1 & 18.4 & 46 & 6.44 \\
\hline 09 & 75 & 35 & 401.12 & 39 & 92.9 & 612.35 & 569 & 101.2 & 1.65 & 6 & 1.97 \\
\hline 10 & 418 & 160 & 891.62 & 158 & 427.8 & 96.08 & 1302 & 225.1 & 9.66 & 29 & 12.91 \\
\hline 11 & 300 & 183 & 1479.63 & 57 & 209 & 25.82 & 569 & 104.72 & 5.86 & 4 & 0.56 \\
\hline 12 & 405 & 90 & 218.67 & 50 & 104.3 & 44.45 & 362 & 51.9 & 5.87 & 8 & 0.74 \\
\hline 13 & 60 & 7 & 23.89 & 7 & 29.7 & 5.64 & 200 & 36.3 & 3.66 & 2 & 0.19 \\
\hline 14 & 12 & 1 & 0.3 & 11 & 27.6 & 3.76 & 276 & 45.1 & 1059.95 & 3 & 1.23 \\
\hline 15 & 6 & 34 & 193.24 & 1 & 107 & 4.55 & 186 & 34.4 & 2.9 & 1 & 0.08 \\
\hline 16 & 7 & 3 & 3 & 0 & 0 & 3.13 & 97 & 18.7 & 1.17 & 0 & 0 \\
\hline Total & 1975 & 993 & 6638.09 & 473 & 1304.6 & 1073.91 & 5403 & 968.92 & 1315.75 & 235 & 83.03 \\
\hline
\end{tabular}


Table 7-6. Vertical Distribution of Artifacts and Ecofacts Recovered from Block 2, 41MM340

\begin{tabular}{|c|c|c|c|c|c|c|c|c|c|c|c|}
\hline \multirow{2}{*}{$\begin{array}{c}\text { Zone } \\
1 \\
\end{array}$} & \multirow{2}{*}{$\begin{array}{c}\begin{array}{c}\text { Chipped } \\
\text { Stone }\end{array} \\
105 \\
\end{array}$} & \multicolumn{2}{|c|}{ FCR } & \multicolumn{2}{|c|}{ Mussel Shell Umbo } & \multirow{2}{*}{$\begin{array}{c}\begin{array}{c}\text { Mussel Shell } \\
\text { Fragments }\end{array} \\
134.22 \\
\end{array}$} & \multicolumn{2}{|c|}{ Snail Shell } & \multirow{2}{*}{$\begin{array}{c}\begin{array}{c}\text { Snail Shell } \\
\text { Fragments }\end{array} \\
3.88 \\
\end{array}$} & \multicolumn{2}{|c|}{ Bone } \\
\hline & & 158 & 809.8 & 151 & 747.5 & & 1796 & 304 & & 12 & 0.17 \\
\hline 2 & 432 & 779 & 4238.73 & 1414 & 16365.14 & 244.46 & 725 & 151.09 & 4.74 & 89 & 19.09 \\
\hline 3 & 49 & 91 & 606.49 & 8 & 31.7 & 8.14 & 35 & 18.7 & 4.9 & 7 & 2.27 \\
\hline 4 & 1636 & 5348 & 37305.29 & 313 & 1211.7 & 416.79 & 1607 & 332.4 & 440.4 & 224 & 103.67 \\
\hline 5 & 254 & 325 & 2667.13 & 25 & 87.3 & 67.91 & 409 & 73.3 & 10.6 & 38 & 14.29 \\
\hline 6 & 459 & 481 & 2019.08 & 70 & 148.4 & 64.03 & 558 & 105.7 & 10.23 & 21 & 3.95 \\
\hline 7 & 453 & 238 & 738.64 & 136 & 350 & 160.87 & 814 & 155.7 & 179.45 & 31 & 6.98 \\
\hline 8 & 1511 & 832 & 7492.8 & 655 & 1810.25 & 401.95 & 1927 & 1023.9 & 409.36 & 195 & 74.68 \\
\hline Total & 4899 & 8252 & 55877.96 & 2772 & 20751.99 & 1498.37 & 7871 & 2164.79 & 1063.56 & 617 & 225.1 \\
\hline
\end{tabular}

Based on the distribution of the number of chipped stone artifacts by excavation level, two peaks, possibly representing depositional zones, can be identified in Block 1. The upper peak includes Levels 6-8, while the lower peak consists of Levels 10-12. The tabulation of cortex categories within these two samples of debitage ( $\mathrm{n}=644$ upper zone; $\mathrm{n}=1107$ lower zone) shows no differences between them. Seventy percent of the debitage is decorticate while 30 percent is corticate in both samples. These percentages are roughly representative of full reduction sequences that progress from locally available corticate nodules to finished bifacial artifacts such as large projectile points and/or bifacial knives. Although it is likely that finished tools were also rejuvenated on site, the debitage collection is not dominated by the products of the early or late stages of reduction.
The breakdown of corticate and decorticate debitage within the eight zones of Block 2 does indicate some variability. The proportion of decorticate debitage ranges from as low as 70-71 percent in the two upper zones ( 1 and 2), to the mid-seventies (76, 77, 77, and 75 ) in Zones 3, 4, 6, and 8, respectively, and as high as 86 and 80 percent in Zones 5 and 7, respectively. The comparison of the numbers of corticate and decorticate debitage within these zones using adjusted standardized residuals indicates that tertiary debitage is under-represented in Zone 2 and tends to be underrepresented in Zones 1 and 8, and is over-represented in Zone 5 and tends to be over-represented in Zone 7 (Table 7-10).

The percentage of decorticate debitage within the nine zones identified in Block 3 shows a range of 67-81 percent. Zones 1, 4, 8, and 9 have relatively low

Table 7-7. Vertical Distribution of Artifacts and Ecofacts Recovered from Block 3, 41MM340

\begin{tabular}{|c|c|c|c|c|c|c|c|c|c|c|c|}
\hline Zone & $\begin{array}{c}\text { Chipped } \\
\text { Stone }\end{array}$ & \multicolumn{2}{|c|}{ FCR } & \multicolumn{2}{c|}{$\begin{array}{c}\text { Mussel Shell } \\
\text { Umbo }\end{array}$} & $\begin{array}{c}\text { Mussel Shell } \\
\text { Fragments }\end{array}$ & \multicolumn{2}{|c|}{ Snail Shell } & \multicolumn{2}{c|}{$\begin{array}{c}\text { Snail Shell } \\
\text { Fragments }\end{array}$} & \multicolumn{2}{c|}{ Bone } \\
\hline & $\mathrm{N}$ & $\mathrm{N}$ & $\mathrm{Wt}$ (gr.) & $\mathrm{N}$ & $\mathrm{Wt}$ (gr.) & Wt (gr.) & $\mathrm{N}$ & $\mathrm{Wt}$ (gr.) & Wt (gr.) & $\mathrm{N}$ & Wt (gr.) \\
\hline 1 & 277 & 119 & 634.29 & 128 & 616 & 84.18 & 691 & 126.3 & 4.54 & 48 & 28.83 \\
\hline 2 & 211 & 420 & 2230.48 & 118 & 394 & 275 & 226 & 35 & 3 & 199 & 604.33 \\
\hline 3 & 238 & 337 & 1199.57 & 66 & 137 & 81 & 383 & 89 & 2.25 & 26 & 6.79 \\
\hline 4 & 806 & 3027 & 17786 & 976 & 2374 & 560 & 1193 & 265 & 105.28 & 172 & 49.64 \\
\hline 5 & 114 & 56 & 857 & 214 & 2380 & 308 & 218 & 10 & 9 & 36 & 6 \\
\hline 6 & 371 & 940 & 10535 & 388 & 1445 & 670 & 327 & 42 & 68 & 92 & 40 \\
\hline 7 & 143 & 1276 & 7589 & 434 & 1301 & 237 & 856 & 444 & 102 & 28 & 6.81 \\
\hline 8 & 444 & 582 & 5634 & 1154 & 4808 & 259 & 5297 & 2955.2 & 514 & 144 & 66.61 \\
\hline 9 & 67 & 115 & 1099 & 54 & 206 & 36 & 327 & 136.72 & 26 & 3 & 0.3 \\
\hline Total & 2671 & 6872 & 47564.34 & 3532 & 13661 & 2510.18 & 9518 & 4103.22 & 834.07 & 748 & 809.31 \\
\hline
\end{tabular}


Table 7-8. Standardized Artifact and Ecofact Distribution, Block 2, 41MM340

\begin{tabular}{|c|c|c|c|c|c|}
\hline Zone & Chipped Stone & FCR wt (gr.) & Mussel wt (gr.) & Snail wt (gr.) & Bone Count \\
\hline 1 & 8.20 & 63.26 & 68.88 & 24.05 & 0.94 \\
\hline 2 & 261.82 & 2568.93 & 10066.43 & 94.44 & 53.94 \\
\hline 3 & 33.33 & 412.58 & 27.10 & 16.05 & 4.76 \\
\hline 4 & 180.97 & 4126.69 & 180.14 & 85.49 & 24.78 \\
\hline 5 & 62.56 & 656.93 & 38.23 & 20.67 & 9.36 \\
\hline 6 & 126.80 & 557.76 & 58.68 & 32.02 & 5.80 \\
\hline 7 & 39.05 & 63.68 & 44.04 & 28.89 & 2.68 \\
\hline 8 & 141.21 & 700.26 & 206.75 & 133.95 & 18.22 \\
\hline Total & 853.95 & 9150.08 & 10690.26 & 435.57 & 120.48 \\
\hline
\end{tabular}

percentages of tertiary flakes. Zones 2,3 , and 5 have the highest percentages of decorticate debitage in the block. The comparison of the numbers of corticate and decorticate debitage within these zones, using adjusted standardized residuals, indicates that tertiary debitage is under-represented in Zone 1 and 8, and tends to be under-represented relative to corticate debitage in Zone 4 (Table 7-11). Tertiary debitage is over-represented in Zones 2, and 3, and tends to be over-represented in Zones 5 and 6.

The comparison of these trends in the two blocks reveals that tertiary debitage tends to be under-represented in Zone 1 and 8, and over-represented in Zone 5. In addition, the percentages of tertiary debitage tend to be high in Zone 3 ( 76 percent in Block 2, 81 percent in Block 3), Zone 5 (86 percent in Block 2; 79 percent in Block 3), Zone 6 (77 percent in Block 2, 77 percent in Block 3), and Zone 7 (80 percent in Block 2; 77 percent in Block 3). The relative percentages of decorticate debitage in the other zones of the two blocks appear to be contradictory (see Zones 2 and 8 ).

In general, the reduction of nodules to finished bifacial artifacts (e.g., large dart points and/or bifacial knives) tends to generate around 70 percent decorticate debitage. The higher percentages in Zones 3, 5, 6, and 7 across the two blocks suggests that the debitage samples have a somewhat higher proportion of late reduction stage debitage than would normally be expected. Such a pattern may derive from the utilization of tertiary flake cores for tool manufacture and/or the repair and rejuvenation of finished tools. The between block differences in Zones 2 and 8 may reflect intrasite structural differences in activity area use.

To investigate the possibility that biface and uniface manufacture may have been carried out in different proportions in the different zones of 41MM340, all of the move than 2,600 pieces of unmodified debitage

Table 7-9. Standardized Artifact and Ecofact Distribution, Block 3, 41MM340

\begin{tabular}{|c|c|c|c|c|c|}
\hline Zone & Chipped Stone & FCR wt (gr.) & Mussel wt (gr.) & Snail wt (gr.) & Bone count \\
\hline 1 & 22.89 & 52.42 & 57.86 & 10.81 & 3.96 \\
\hline 2 & 60.28 & 637.28 & 191.14 & 10.85 & 56.85 \\
\hline 3 & 29.02 & 146.28 & 26.58 & 11.12 & 3.17 \\
\hline 4 & 244.24 & 5389.69 & 889.09 & 112.2 & 52.11 \\
\hline 5 & 54.28 & 408.09 & 1280 & 9.04 & 17.14 \\
\hline 6 & 132.5 & 3762.5 & 755.35 & 39.28 & 32.85 \\
\hline 7 & 30.42 & 1614.68 & 327.23 & 116.17 & 5.95 \\
\hline 8 & 83.78 & 1063.01 & 956.03 & 654.56 & 27.16 \\
\hline 9 & 5.58 & 91.58 & 17.19 & 13.56 & 0.25 \\
\hline Total & 662.99 & 13165.53 & 4500.47 & 977.59 & 199.44 \\
\hline
\end{tabular}


from Block 3 was categorized into distinct flake types (i.e., biface manufacture, biface thinning, uniface manufacture and rejuvenation, core reduction, blade production, core/platform preparation, and notching flakes). The large proportion of the identified flake types ( $\mathrm{n}=1,214,46$ percent) are core/platform preparation flakes. Only seven (less than one percent) blades were identified in the sample and not surprisingly, only four (less than one percent) debitage were identified as clearly representing core reduction rather than biface manufacture. Six of the seven blades are from Zone 6 . Thirty-two (1.2 percent) notching flakes were identified, with 15 (0.6 percent) occurring in Zone 6 or below ( 80 percent from Zone 6). Biface manufacture flakes constitute a total of 713 (27 percent) of the total sample, about half of these $(n=355)$ are biface thinning flakes. Uniface manufacture flakes make up a small proportion of the sample $(n=106,4$ percent $)$.

The comparison of the frequencies of biface manufacture, biface thinning, and uniface manufacture debitage by zone indicates that biface thinning flakes are under-represented in Zone 1 and over-represented in Zone 3 (Table 7-12). These flake types also tend to be under-represented in Zone 7, although not to a statistically significant degree. Biface manufacture flakes (i.e., early and middle reduction stage flakes) have the opposite tendency. Thinning flakes are under-represented in Zone 3, and over-represented in Zone 7. There is also a tendency, although not statistically significant, for thinning flakes to be over-represented in Zone 1 and under-represented in Zone 8. Uniface manufacture/rejuvenation debitage tends to be underrepresented in Zones 2, 4, 5, and 7, and over-represented in Zones 6, 8, and 9.

The tendency for early (manufacture) and late (thinning) reduction stage debitage to exhibit contrasting distribution patterns in Zones 1, 3, and 7 may reflect differences in biface manufacture strategies. The overrepresentation of biface manufacture (early and middle stage) debitage in Zones 1 and 7 may reflect the stage manufacture of unfinished bifaces for transport to other localities. On the other hand, the over-representation of thinning flakes in Zone 3 may indicate an emphasis on the manufacture of finished bifaces, potentially indicating "gearing-up" for activities that are expected to necessitate large numbers of finished bifaces (e.g., projectile points and/or knives).
Table 7-10. Comparison of debitage cortex categories using adjusted standardized residuals, Block 2, 41MM340

\begin{tabular}{|c|c|c|}
\hline Zone & Corticate & Decorticate \\
\hline 1 & 1.52 & -1.52 \\
\hline 2 & $\mathbf{2 . 7 6}$ & $\mathbf{- 2 . 7 6}$ \\
\hline 3 & 0.2 & -0.2 \\
\hline 4 & -0.72 & 0.72 \\
\hline 5 & $\mathbf{- 3 . 6}$ & $\mathbf{3 . 6}$ \\
\hline 6 & -0.28 & 0.28 \\
\hline 7 & -1.74 & 1.74 \\
\hline 8 & 1.52 & -1.52 \\
\hline
\end{tabular}

Bold numbers represent statistically significant adjusted standardized residuals significant at the 0.05 level of significance (+/- 1.96; Everitt 1977:47).

Table 7-11. Comparison of debitage cortex categories using adjusted standardized residuals, Block 3 , 41MM340

\begin{tabular}{|c|c|c|}
\hline Zone & Corticate & Decorticate \\
\hline 1 & $\mathbf{2 . 4 6}$ & $\mathbf{- 2 . 4 6}$ \\
\hline 2 & $\mathbf{- 1 . 9 7}$ & $\mathbf{1 . 9 7}$ \\
\hline 3 & $\mathbf{- 2 . 8 9}$ & $\mathbf{2 . 8 9}$ \\
\hline 4 & 1.83 & -1.83 \\
\hline 5 & -1.51 & 1.51 \\
\hline 6 & -1.74 & 1.74 \\
\hline 7 & -0.96 & 0.96 \\
\hline 8 & $\mathbf{2 . 5 1}$ & $\mathbf{- 2 . 5 1}$ \\
\hline 9 & 0.25 & -0.25 \\
\hline
\end{tabular}

Bold numbers represent statistically significant adjusted standardized residuals significant at the 0.05 level of significance (+/- 1.96; Everitt 1977:47).

The tendency for uniface manufacture/rejuvenation flakes to be over-represented in the deeper zones may suggest that activities necessitating unifacial tools such as scrapers (i.e., hide processing) and/or unifacial adzes (i.e., wood working) may have been more prevalent during the earlier occupations of the site. Although very preliminary, it may be worth further exploration to determine whether these patterns signal a connection of the inhabitants of the site to Blackland Prairie bison hunting adaptations. 
Table 7-12. Comparison of the occurrence of three flake types by zone using adjusted standardized residuals, Block 3, 41MM340

\begin{tabular}{|c|c|c|c|}
\hline Zone & $\begin{array}{c}\text { Biface } \\
\text { manufacture }\end{array}$ & $\begin{array}{c}\text { Biface } \\
\text { thinning }\end{array}$ & $\begin{array}{c}\text { Uniface } \\
\text { manuf./rejuv. }\end{array}$ \\
\hline 1 & 1.87 & $\mathbf{- 2 . 5 4}$ & 0.99 \\
\hline 2 & 0.27 & 0.86 & -1.66 \\
\hline 3 & $\mathbf{- 2 . 2 9}$ & $\mathbf{2 . 3 5}$ & -0.09 \\
\hline 4 & 0.64 & 0.47 & -1.64 \\
\hline 5 & 0.43 & 0.82 & -1.8 \\
\hline 6 & -1.33 & 0.01 & $\mathbf{1 . 9 5}$ \\
\hline 7 & $\mathbf{2 . 1 2}$ & -1.34 & -1.15 \\
\hline 8 & -0.41 & -0.88 & 1.9 \\
\hline 9 & -0.88 & 0.01 & 1.27 \\
\hline
\end{tabular}

Bold numbers represent statistically significant adjusted standardized residuals significant at the 0.05 level of significance (+/- 1.96; Everitt 1977:47).

\section{Vertebrate Faunal Material}

Barbara A. Meissner, Center for Archaeological Research, The University of Texas at San Antonio provided analyses of vertebrate faunal material recovered from the three excavation blocks at 41MM340. According to her report (Appendix C), the predominantly fragmented bone is generally in moderate to good condition, with five genera of mammals, one genus of reptile, and one genus of fish identified. The majority of the unidentified bone appeared to be from animals of the deer/antelope size category; however, based on cortical thickness, at least two unidentified bones could have come from a bison-sized animal. Additionally, highly fragmented, unidentifiable specimens of bird, turtle, and fish were present. There is little evidence of extensive atmospheric or chemical weathering, suggesting clayey, fluvial deposits buried the material shortly after initial fragmentation and subsequent deposition. Overall, a relatively small amount of faunal material was encountered within these otherwise rich, cultural deposits. In addition, a majority of the bone encountered is highly fragmented, suggesting the material was heavily processed. Further analyses may provide a clearer interpretation of the relative paucity of remains and the extent to which the remains present were processed.

\section{Freshwater Mussel Shell}

Robert G. Howells conducted analyses of freshwater mussel specimens recovered from three of the four cultural zones encountered at 41MM340 (Appendix D). Samples of 50 specimens selected to contain a variety of species from Zones 2, 6, and 8 were submitted. According to his report, all specimens were in very good condition, with seven species identified, representing the Family Unionidae. Threeridge (Amblema plicata), the most abundant unionid taxon within the Central Brazos River Drainage, displayed a marked increase from Zone $8(124-134 \mathrm{~cm}$ bs) to Zone 2 (43-53 cm bs). Conversely, smooth pimpleback (Quadrula houstonensis) exhibited a proportionately greater decrease between the two zones. As freshwater mussels are sensitive environmental barometers, one possibility for this change in mussel population could be the regional climatic change toward a more arid environment. Despite this population variation, all the taxa represented in the archaeological assemblage evolved in flowing waters and are most often associated with gravel, stable sand, and mud substrates in permanent-water conditions. No species representing slow moving, soft-bottomed stream conditions were identified. These data suggest the site was formerly in relative close proximity to a perennial stream, possibly a former meander of the Little River, and occupation may have ended before the meander was entirely cut off.

\section{Macrobotanical}

J. Philip Dering, Associate Director for Macrofossil Analyses, Paleoethnobotany Laboratory, Texas A\&M University performed macrobotanical analyses of flotation samples recovered from each of the four cultural zones encountered within Block 3 (Appendix E). According to his report, the archaeobotanical assemblage, both in quantity and size of the material, is somewhat reduced. The four samples submitted for analysis yielded only 16 very small $(1-3 \mathrm{~mm})$ wood fragments (Quercus sp. and Ilex sp.). Although the archaeobotanical assemblage is somewhat reduced, that botanical data have yielded some promising results. Nut fragments (pericarp fragments) were recovered from three of the five (60 percent) flotation 
samples examined. At least two nut types, thin (cf. pecan) and thick (cf. hickory), were identified in the assemblage. Due to the overall paucity of botanical remains exhibited in the general level samples submitted, future analyses should be directed toward samples recovered from heating features, which are conducive to the preservation of botanical materials, and from samples recovered for ${ }^{14} \mathrm{C}$ dating since they contained the bulk of the large pieces of carbonized plant remains.

\section{Pollen and Phytolith}

Analyses of pollen and phytolith samples extracted from each cultural zone were performed by John G. Jones, Associate Director for Pollen Analyses, Palynology Laboratory, Texas A\&M University (Appendix F). Pollen and phytolith specimens were noted within the samples submitted, however, the overall state of preservation was poor. The pollen concentration values within the four cultural zones are, from upper to lower strata: 2,250 grains/ml, 936 grains $/ \mathrm{ml}, 1,017$ grains $/ \mathrm{ml}$, and 1,631 grains $/ \mathrm{ml}$. Environmental factors such as cyclic wetting and drying in combination with the acid soils $(8.4 \mathrm{pH})$ of the region are not conducive to the preservation of pollen or phytoliths, and, as such, the overall yield, or concentration value of the individual samples do not lend themselves to reliable interpretations.

\section{Land Snail Shell}

Richard W. Fullington conducted analyses of gastropod samples extracted from each cultural zone (Appendix G). The samples consisted of snails recovered from light and heavy fraction flotation and from $1 / 4$ inch screen. According to his report, all specimens were in excellent condition, with thirteen species identified, representing ten families. The species represented throughout the vertical column suggest little variance in the environmental conditions within the immediate area. Nonetheless, snail species preferring open and/or sparsely wooded habitats (e.g., Rabdotus dealbatus dealbatus) are in abundance in the two deepest cultural zones, woodland habitat preference species dominate the middle zones, and species preferring open to sparsely wooded habitats again dominate the uppermost cultural zone. Overall, there appears to be a trend toward a drier environment through time as represented within the four cultural zones. Alternatively, the shifts in dominant species through time might reflect changes in vegetation cover on the floodplain of Little River. The gastropod shells examined appear to be deposited in situ and not from fluvial transport. The relatively low number of species present and the occurrence of only one species of aquatic gastropod support this. Furthermore, there appears to be little difference in the frequency of specimens encountered among the cultural zones. These data suggest that each cultural zone represents a relatively short time span with a low snail population density.

\section{Diatom}

Barbara Winsborough, of Winsborough Consulting, conducted analyses of four sediment samples and four fired clay samples from site 41MM340 (Appendix H). In addition, three modern comparative samples -water from Little River, bottom sludge from Little River, and topsoil from modern slough-were also examined for diatom assemblages. The sediment samples were collected from each of the four cultural zones in Block 3 and BHT A. Evidence of diatoms was absent in the archaeological samples. The other half of the samples consisted of fired clay nodules recovered from various hearth features throughout the vertical column. Three of the four clay nodule samples examined contained diatoms. Positive samples recovered from lower strata contained only a few aerophilic diatoms (found in soil and mud), indicating that, while the fired clay nodules do preserve diatoms to an extent, the nature of the flood deposits normally preclude preservation of diatoms. However, a single sample associated with Zone 2, recovered in association with a hearth feature extending just beneath the zone in Block 3, was the most diatomaceous, with 500 cells counted. The sample contained 25 species, representing a mixture of aerophilic diatoms and benthic aquatic species found attached to emergent vegetation and macroalgae. The presence of this assemblage of diatoms suggests that they may have been transported to the site from a nearby stream, possibly attached to mussels or other edible material. 


\section{Summary}

Our limited hand testing at 41MM340, coupled with extensive augering and supported by backhoe trenching has demonstrated that the site potentially contains a variety of data sets with relevance to a small portion of the Late Archaic. In Block 1, while distinctive strata could not be identified, a consideration of artifact distribution clearly suggests that two, and perhaps three, distinct zones may be present. A series of radiocarbon dates on the feature recorded in BHT 26 suggests that some of this occupation occurred at around 970 B.C. This is within the time frame reflected by radiocarbon dates for both Blocks 2, and 3, where a series of occupations that appear to date from about 1400 to 450 B.C. were discovered. Not only do all three blocks have data that are from a small span of the Late Archaic, but in both Blocks 2 and 3, a series of cultural strata could be defined which subdivide this roughly 1,000 year accumulation into units that, in many cases, are within the standard deviation of the associated radiocarbon dates. While it is currently impossible to assign precise time limits to the various deposits within the Block 2 and 3 testing, the various cultural layers appear to have accumulated rapidly, and certainly contain a variety of data sets relevant to questions of both adaptation and change during the Late Archaic.

\section{$41 \mathrm{MM341}$}

\section{Auger Data}

Excavations of auger borings at 41MM341 revealed a single areal concentration of cultural material extending the general width and approximately $50 \mathrm{~m}$ (164 ft.) along the present and proposed rights-of-way (see Figure 6-2). A total of 121 auger borings were excavated, encountering no evidence of former stream meanders in the form of wet soils or sediments. While a slough exists to the south of the site bounds, there was no indication in the auger boring excavations that this current slough has migrated through the site limits.

\section{Cultural Stratigraphy}

Similar to the northern section of 41MM340, this site initially exhibited no obvious cultural stratigraphy to warrant excavation using cultural strata. As such, manual excavation of the two blocks proceeded in arbitrary 10-cm (4-in.) levels throughout the 1.6-m (5.25$\mathrm{ft}$.) vertical column.

During post-field analysis, based on the changes in artifact densities by level, the distribution of diagnostic chipped lithic artifacts, feature concentrations, and radiocarbon assays, it was determined that three cultural zones could be discerned within the two blocks of the site. Zone 1 is represented by the upper 50-70 $\mathrm{cm}$ of deposits across Block 1. A majority of the upper aspect of Zone 1, that portion containing the Toyah Phase, was likely removed with mechanical excavation of $3 / 4$ of the excavation block. The zone is characterized by low artifact densities, few chipped lithics, a sparse scattering of mussel shell, and thirteen aboriginal ceramics. A small circular unlined pit feature (Feature 1) was also within this zone. In Block 2, Zone 1 is manifested by a low density of chipped lithics overlying Zone 2. Zone 2 in Block 1 consisted of a 15-20 cm thick discrete shell lens containing large numbers of burned rock, mussel shell, and chipped lithics. A lithic reduction station (Feature 3 ) and a rocklined hearth (Feature 5) were also part of the cultural zone. In Block 2, this zone lacked the midden-like character. Although low frequencies of chipped lithics and mussel shell were present in the zone, hearth features (Features 2, and 4) rather than refuse accumulations, characterized the zone. Burned rocks are abundant in the zone. Zone 3 in Block 1 begins between $85-90 \mathrm{~cm}$ bs and underlies the material-rich midden zone. Low numbers of unmodified debitage, mussel shells, and burned rock continue to a depth of $160 \mathrm{~cm}$ bs. In Block 2, this zone is characterized by moderate to high numbers of unmodified debitage, but low numbers of burned rocks and mussel shells. 
Table 7-13. Beta Analytic, Inc., results of radiocarbon dating for samples recovered from 41MM341

\begin{tabular}{|c|c|c|c|c|c|c|c|c|}
\hline Block & Elevation & $\begin{array}{c}\text { Aspect of } \\
\text { Feature/ } \\
\text { Stratum }\end{array}$ & Beta \# & $\begin{array}{c}\text { Measured } \\
\text { Radiocarbon } \\
\text { Age }\end{array}$ & $\begin{array}{c}{ }^{13} \mathbf{C} /{ }^{\mathbf{1 2}} \mathbf{C} \\
\text { Ratio }\end{array}$ & $\begin{array}{c}\text { Corrected } \\
\text { Radiocarbon } \\
\text { Age }\end{array}$ & $\begin{array}{c}\text { Calibrated AD } \\
\text { Range at 1 Sigma }\end{array}$ & $\begin{array}{c}\text { Calibrated AD } \\
\text { Range at 2 Sigma }\end{array}$ \\
\hline 1 & $40-50 \mathrm{cmbs}$ & lower & 141841 & $520+/-40 \mathrm{BP}$ & $-26.4 \%$ & $500+/-40 \mathrm{BP}$ & $1407-1440$ & $1320-1480$ \\
\hline 1 & $70-80 \mathrm{cmbs}$ & lower & 141842 & $1280+/-40 \mathrm{BP}$ & $-25.7 \%$ & $1270+/-40 \mathrm{BP}$ & $685-780$ & $660-880$ \\
\hline 2 & $60-70 \mathrm{cmbs}$ & lower & 141843 & $940+/-40 \mathrm{BP}$ & $-24.9 \%$ & $940+/-40 \mathrm{BP}$ & $1020-1160$ & $1010-1190$ \\
\hline
\end{tabular}

\section{Radiocarbon}

Beta Analytic, Inc., of Miami, Florida (Beta), provided radiocarbon assays for three charcoal samples recovered from 41MM341 (Figures 7-18 and 7-19; Table 7-13). These were calibrated using the OxCal program (Ramsey 2000). Radiometric sampling (Beta \#141841) from Zone 1 in Block 1 produced a corrected date of $500 \pm 40 \mathrm{BP}$, which when calibrated yields a 1 sigma range of A.D. 1407-1440. This period corresponds with the Perdiz Phase. The second sample submitted from Block 1 was recovered from $70-80 \mathrm{~cm}$ bs from the lower-middle portion of Zone 2 , the discrete shell lens. The sample (Beta \#141842) dates the lower-middle portion of the discrete shell lens at $1270 \pm 40 \mathrm{BP}$, with a calibrated 1 sigma range of A.D. 685-780. This date places the discrete shell lens at the beginning of the Austin Phase.
The single sample submitted from Block 2 was recovered from the lower aspect of a large $(\sim 200 \mathrm{~cm}$ diameter) hearth feature (Feature 4) in Zone 2. The hearth was encircled with stone and contained moderate amounts of fired clay and fire-cracked rock and an abundant amount of charcoal. The charcoal sample produced a corrected date of $940 \pm 40 \mathrm{BP}$, which, when calibrated, has a 1 sigma range of A.D. 1020-1160 (Beta \#141843). Along with the single Scallorn arrow point recovered from the same level of the block, this date places the feature within the Austin Phase of the Late Prehistoric Period. While the probable associated feature (Feature 2) originally recorded in the survey-phase backhoe trench (BHT 15) was not dated, charcoal recovered from BHT 17, located $\sim 20 \mathrm{~m}$ to the north and within the site limits, produced a corrected date of $1050 \pm 50$ BP (A.D. $\sim 900)$ (Beta \#128740), again consistent with the Austin Phase.

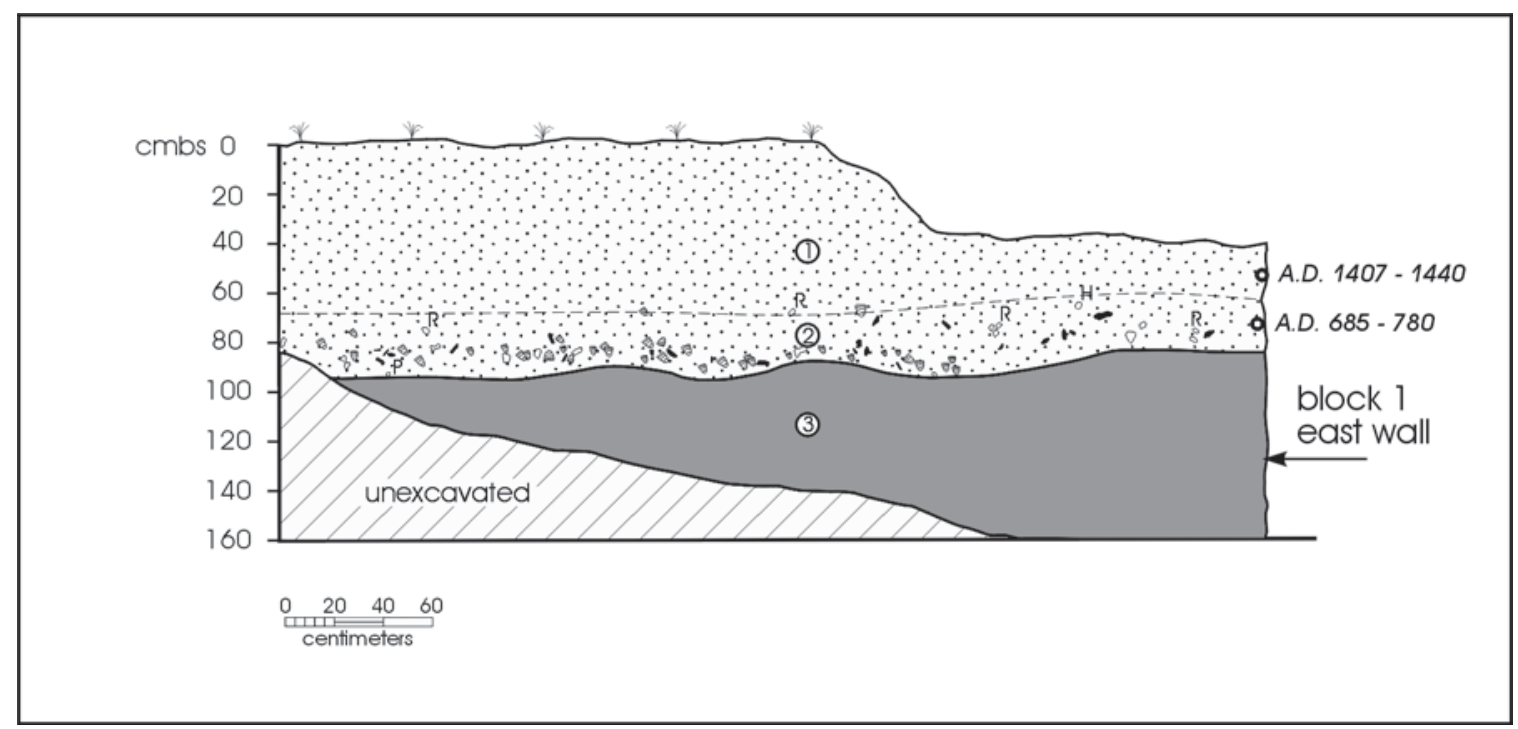

Figure 7-18. Profile of south wall of BHT 24 showing occupation zones and dates of radiocarbon assays, $41 M M 341$. 


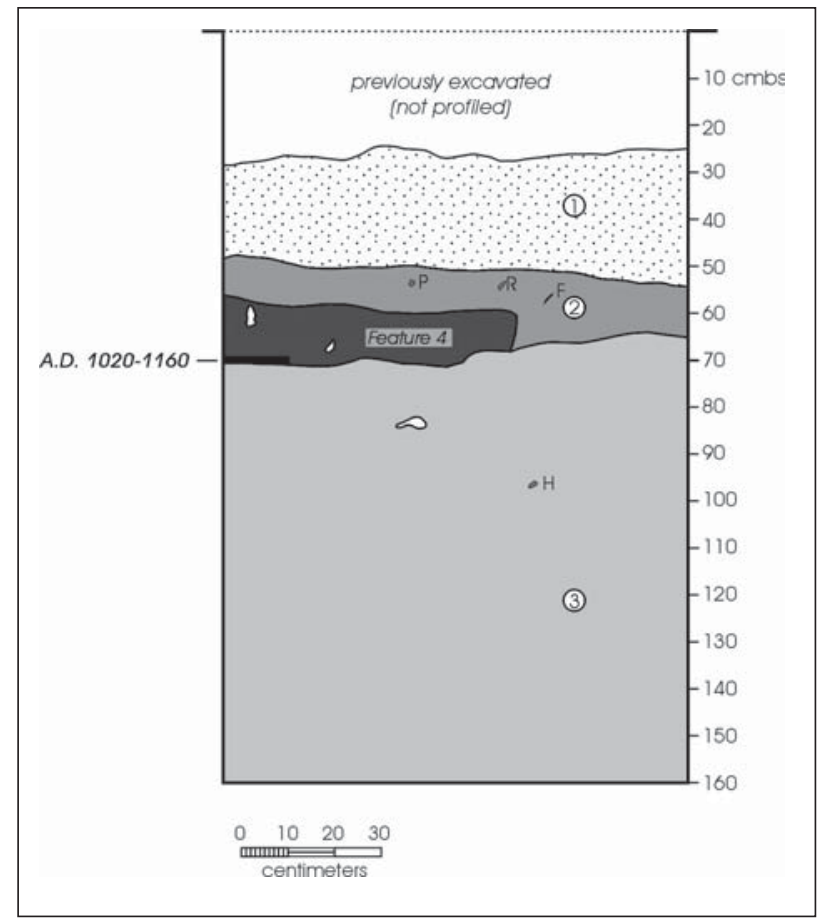

Figure 7-19. Profile of east wall of Unit D, Block 2 showing occupation zone and date of radiocarbon assay, 41MM341.

\section{Temporal Diagnostic Chipped Stone Tools and Ceramics}

Three temporally diagnostic tools were recovered from 41MM341. In addition, 13 prehistoric ceramic fragments also were recovered from Block 1. Table 7-14 shows the distribution of the tools and ceramics by block, unit, excavation zone, and level. The single arrow point is a medial fragment recovered from the middle portion of Zone 2 (60-70 cm bs) of Block 2. A sufficient amount of the stem remains to classify it as a Scallorn point (Figure 7-20a), an index marker of the Austin Phase. A Friday knife was recovered from the lower portion of Zone $2(86 \mathrm{~cm} \mathrm{bs})$ in the same block. The well-flaked triangular biface has a slightly concave base and beveled and systematically serrated blade edges (Figure 7-20b). Friday knives tend to occur in deposits spanning the Late Archaic II and the Austin Phase of the Late Prehistoric Period (Turner and Hester 1993). The third temporally diagnostic specimen is a manufacture failed roughly parallelsided Hare biface (Figure 7-20c). It was recovered in an auger hole at a depth of about $20 \mathrm{~cm}$ bs. Hare bifaces may represent knife and/or dart point preforms and tend to occur in Late Archaic I assemblages (Prewitt 1982:Figure 37; Turner and Hester 1993).

Eleven of the 13 prehistoric ceramics were recovered at about $30 \mathrm{~cm}$ bs in Block 1. Based on construction method and temper, these specimens are likely to date to the later part of the Late Prehistoric Period (i.e., Toyah Phase).

The presence of ceramics at a depth of $30 \mathrm{~cm} \mathrm{bs}$, slightly above a radiocarbon assay of A.D. 1320-1480 (2 sigma range) from $40-50 \mathrm{~cm}$ bs in Block 1 , is consistent with the Toyah Phase temporal assignment of Zone 1. The co-occurrence of the Scallorn arrow point and Friday knife in the dense occupation zone dated between A.D. 660-880 (2 sigma range) is consistent with the Austin Phase affiliation of the Zone 2 component. The possible Late Archaic II specimen (the Hare biface) at a depth of 0-20 cm bs may be indicative of some degree of disturbance. Nonetheless, its

Table 7-14. Distribution of chipped stone tools and ceramics by block, unit, zone, and level, at 41MM341

\begin{tabular}{|c|c|c|c|c|c|r|l|}
\hline Lot & Block & Unit & Zone & Level & Depth & Artifact Category & \multicolumn{1}{c|}{ Comments } \\
\hline 55 & 2 & C & 2 & 7 & $60-70 \mathrm{cmbs}$ & Scallorn arrow point & Medial fragment; Figure 7-20a \\
\hline 90 & 2 & A & 2 & 9 & at $86 \mathrm{cmbs}$ & Friday knife & Complete; beveled and serrated edges; Figure 7-20b \\
\hline 165 & AB-57 & 1 & 2 & at $20 \mathrm{cmbs}$ & Hare biface & Complete; Figure 7-20c \\
\hline 3 & 1 & B & 1 & 3 & at $30 \mathrm{cmbs}$ & Native Ceramic & Two Fragments (Appendix J) \\
\hline 6 & 1 & A & 1 & 3 & $20-30 \mathrm{cmbs}$ & Native Ceramic & Nine Fragments (Appendix J) \\
\hline 167 & \multicolumn{2}{|c|}{ BHT 24 } & &. & backdirt & Native Ceramic & Two Fragments (Appendix J) \\
\hline
\end{tabular}


temporal affiliation may support the likelihood that Zone 3 in both blocks may date to the Late Archaic II.

\section{Aboriginal Ceramics}

Timothy K. Perttula analyzed thirteen prehistoric ceramic sherds recovered from Block 1, Units A and B, and BHT 24 (Appendix J). Eleven of the sherds were recovered in situ at approximately $30 \mathrm{~cm}$ bs, with the remainder encountered in the backdirt of BHT 24. The sherds are from two different vessels, a probable thickwalled jar and an incised carinated bowl. The probable jar sherds have finely crushed and burned bone temper inclusions, with an average wall thickness of approximately $8.8 \mathrm{~mm}$. The incised carinated bowl sherds are tempered with bone and grog, with a sandy clay paste, and an average wall thickness of $8.15 \mathrm{~mm}$. While the bowl sherds exhibit characteristics similar to Caddoan vessels, similar sherds have been reported from Post Oak Savanna sites in the Navasota and Brazos River basins (Perttula n.d.; Turpin and Carpenter 1994:17). The sherds are also reminiscent of Toyah Phase sherds from the Rowe Valley site (M. Tomka, personal communication, 2000). To ascertain the manufacturing locale of the two different vessels, Perttula recommends that a sherd from each vessel be analyzed by instrumental neutron activation analysis (INAA) and petrographic analysis. The current INAA and petrographic databases for Caddoan and Central Texas ceramics are sufficiently robust (see Perttula 1999) to be able to determine the likely compositional origin of the two vessels.

\section{Feature Descriptions}

A total of five cultural features were identified and excavated at 41MM341. Three features were newly recorded and two (Nos. 2 and 3 ) were previously recorded during the survey phase. Two of the encountered features (Nos. 4 and 5) can be classified as hearths with associated fire-cracked rock, charcoal, and other heat-altered remnants. Two features (Nos. 1 and 2) are interpreted as refuse pits. A single feature (No. 3) is expressed as a discrete shell lens. Table 715 lists the features encountered at 41MM341 by provenience. More detailed descriptions of the individual features are discussed below.

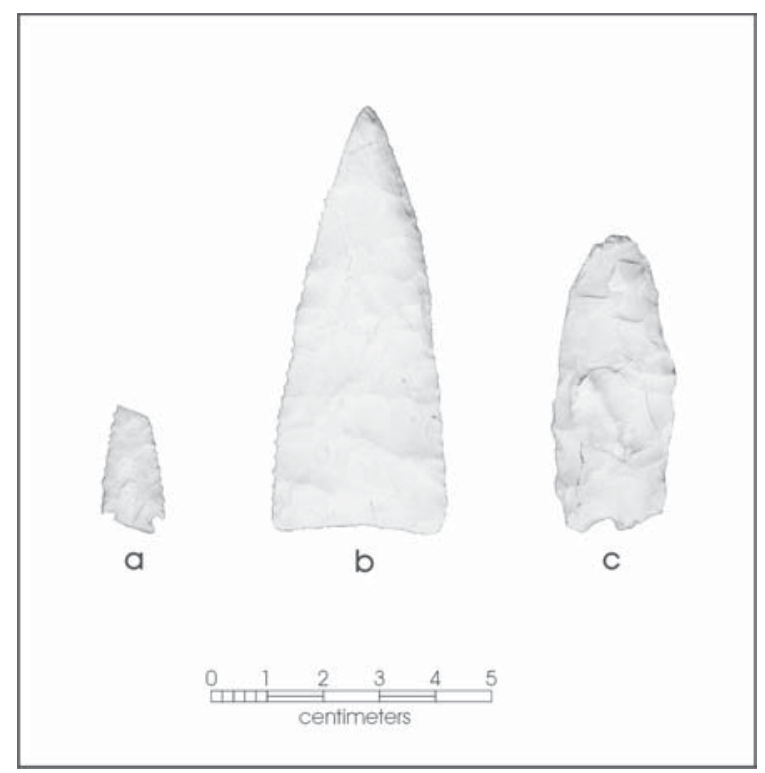

Figure 7-20. Chipped stone tools recovered from 41MM341. a) Scallorn arrow point; b) Friday knife; c) Hare biface.

\section{Feature 1}

Feature 1 is a refuse, or secondary, pit consisting of a dark, midden-stained matrix with charcoal, charcoalstained clay, fired clay, and sparse to moderate mussel shell. The feature was encountered within the first arbitrary 10-cm (4-in.) level at $40 \mathrm{~cm}$ bs in Block 1, XUD; however, the mechanical excavation to this depth probably truncated an unknown amount of the upper portion of the feature. The extant remnant of the feature exhibited a depth of approximately $8 \mathrm{~cm}$ (3 in.). The provenience of this feature, terminal at 48 $\mathrm{cm}$ bs (19 in.), would suggest that it is associated with a somewhat later component than the shell lens, Feature 3 (see Feature 3 description).

\section{Feature 2}

Feature 2 was originally recorded during the TxDOT survey phase in BHT 15 as an apparent hearth feature (Ahr and Abbott 1999:13). Re-excavation of the backhoe trench allowed for the relocation of the feature. Upon manual excavation, however, Feature 2 appears to be a refuse, or secondary, pit feature associated with an unlined hearth, Feature 4 (see below) located approximately $82 \mathrm{~cm}$ (32 in.) to the east. The feature occurs at approximately $50 \mathrm{~cm}$ bs and extends to approximately $75 \mathrm{~cm}$ bs. It appears that a majority of the feature was removed with the initial survey backhoe trench excavation. The remnant portion of the 
Table 7-15. Features encountered during manual excavation at 41MM341

\begin{tabular}{|c|c|c|c|l|}
\hline Feature & Block & Unit & Elevation & \multicolumn{1}{|c|}{ Type } \\
\hline 1 & 1 & D & $40-48 \mathrm{cmbs}$ & Unlined pit feature. \\
\hline 2 & 2 & A, C & $50-75 \mathrm{cmbs}$ & Unlined pit feature. \\
\hline 3 & 1 & A. B. D & $60-70 \mathrm{cmbs}$ & Freshwater mussel shell lens. \\
\hline 4 & 2 & B, D & $56-74 \mathrm{cmbs}$ & Unlined hearth feature. \\
\hline 5 & 1 & B, D & $75-82 \mathrm{cmbs}$ & Rock-lined hearth. \\
\hline
\end{tabular}

feature is irregular in shape and measures $23 \mathrm{~cm}$ (9 in.) wide and $115 \mathrm{~cm}$ (45 in.) long. The rich, midden-stained soil of the refuse pit included burned clay, chipped stone, mussel shell, and small fragments of burned rock

\section{Feature 3}

Feature 3 was initially identified during the survey phase as a possible early stage lithic reduction station, with associated primary and secondary corticate flakes and an abundant concentration of mussel shell (Ahr and Abbott 1999:14). Subsequent to placement of the excavation block (Block 1), it became apparent that the feature was actually the westernmost portion of a discrete shell lens, extending eastward under the elevated portion of State Highway 36. Within the excavation block, the lens occurs from $60-70 \mathrm{~cm}$ bs. The heaviest concentration of mussel shell occurs in XUB, with a peripheral scatter contained in the remaining test units of Block 1.

\section{Feature 4}

Feature 4 is a large basin hearth and consists of a circular arrangement of relatively large $(>10 \mathrm{~cm})$ hearthstones positioned around the edge of the basin. The matrix within the basin is a dark, charcoal-stained material replete with fired clay nodules and charcoal flecks. Sparse amounts of burned bone, chipped stone, and smaller burned rock were also recovered from the interior of the basin. The feature was encountered at approximately $56 \mathrm{~cm}$ (22 in.) below ground surface. The eastern wall of Block 2 bisects the feature, at which point the diameter measures approximately 2 $\mathrm{m}(6.6 \mathrm{ft}$.$) .$

\section{Feature 5}

Feature 5 is a rock-lined basin hearth and consists of a roughly circular concentration of fire-cracked rock with associated fired clay, charcoal, freshwater mussel shell, and lithic debitage. The feature was encountered within
Block 1, XUB and XUD at $80 \mathrm{~cm}$ (31.5 in.) below ground surface. Artifacts recovered from the feature include fire-cracked rock, charcoal, bone, and sparse burned mussel shell fragments. The feature measures approximately $50 \mathrm{~cm}$ (20 in.) in diameter and appeared to exhibit a slight vertical concavity.

\section{Artifact Distribution}

Tables 7-16 and 7-17 present the distribution of artifacts recovered from the two blocks of 41MM341. A look at the distribution of chipped stone, fire-cracked rock (FCR), mussel shell, and animal bone in the upper five levels of Block 1 shows a small peak in three of the four categories in Level 4 corresponding to Zone 1 (Table 7-16 and Figure 7-21). No equivalent peaks are present in Block 2 (Table 7-17 and Figure 7-22). Zone 2 in Block 1 is characterized by peaks in chipped stone artifacts, FCR, animal bone, and mussel shell. The densities of all four categories peak in Level 8 of Block 1 . In Block 2 chipped stone artifacts show only a small peak in Zone 2 (Figure 7-22). The bulk of the materials from Zone 2 in Block 2 consist of FCR. A small peak in animal bone is present in Level 6 of the block. Zone 3 in Block 1 consists of small peaks in chipped lithics, FCR, and mussel shell in Level 10 followed by steadily decreasing frequencies in all three categories in deeper levels. Animal bone densities peak in Level 11 of the block. In Block 2, Zone 3 is characterized by higher densities of chipped lithics, mussel shell, and bone compared to Block 1. In addition to a peak in materials in Level 10 in both blocks, Block 2 also shows a smaller peak in chipped lithics, FCR, and mussel shell in Level 15 (see Table 7-17 and Figure 7-22).

In general, these distribution patterns suggest some important spatial variation in activities carried out during the different occupations across the site. Toyah 
Table 7-16. Vertical Distribution of Artifacts and Ecofacts in Block 1, 41MM341

\begin{tabular}{|c|c|c|c|c|c|c|c|c|c|c|c|c|c|}
\hline \multirow[b]{2}{*}{ Zones } & \multirow[b]{2}{*}{ Level } & \multirow{2}{*}{$\begin{array}{c}\text { Chipped } \\
\text { Stone }\end{array}$} & \multicolumn{2}{|c|}{ FCR } & \multicolumn{2}{|c|}{$\begin{array}{c}\text { Mussel Shell } \\
\text { Umbo }\end{array}$} & \multirow{2}{*}{\begin{tabular}{|c|}
$\begin{array}{c}\text { Mussel Shell } \\
\text { Fragments }\end{array}$ \\
Wt \\
\end{tabular}} & \multicolumn{2}{|c|}{ Snail Shell } & \multirow{2}{*}{$\begin{array}{c}\text { Snail Shell } \\
\text { Fragments }\end{array}$} & \multirow{2}{*}{$\frac{\text { Ceramic }}{\mathbf{N}}$} & \multicolumn{2}{|c|}{ Bone } \\
\hline & & & $\mathbf{N}$ & Wt & $\mathbf{N}$ & Wt & & $\mathbf{N}$ & Wt & & & $\mathbf{N}$ & Wt \\
\hline 1 & 1 & 0 & 0 & 0 & 0 & 0 & 1.32 & 1 & 0.06 & 0.09 & 0 & 0 & 0 \\
\hline 1 & 2 & 0 & 0 & 0 & 0 & 0 & 0 & 0 & 0 & 0 & 0 & 4 & 1.34 \\
\hline 1 & 3 & 5 & 0 & 0 & 2 & 1.9 & 7.49 & 0 & 0 & 0.04 & 9 & 1 & 0.02 \\
\hline 1 & 4 & 21 & 0 & 0 & 1 & 19.1 & 2.32 & 0 & 0 & 0.69 & 2 & 25 & 29.87 \\
\hline 1 & 5 & 3 & 5 & 5.78 & 2 & 6.2 & 6.59 & 10 & 5.5 & 0.81 & 0 & 10 & 22.31 \\
\hline 2 & 6 & 9 & 5 & 3.06 & 14 & 54.4 & 59.22 & 205 & 14.8 & 3.83 & 0 & 6 & 0.87 \\
\hline 2 & 7 & 68 & 24 & 234.25 & 61 & 265.4 & 195.17 & 246 & 80.5 & 17.19 & 0 & 37 & 7.27 \\
\hline 2 & 8 & 174 & 229 & 1851.52 & 101 & 507 & 336.27 & 185 & 50.1 & 25.13 & 0 & 38 & 14.45 \\
\hline 2 & 9 & 10 & 39 & 65.62 & 8 & 21.3 & 64.25 & 224 & 45.6 & 4.64 & 0 & 0 & 0 \\
\hline 3 & 10 & 32 & 42 & 103.5 & 16 & 54 & 22.09 & 590 & 123.8 & 5.23 & 0 & 1 & 1 \\
\hline 3 & 11 & 6 & 0 & 0 & 1 & 0.6 & 4.39 & 368 & 86.7 & 3.52 & 0 & 12 & 6.26 \\
\hline 3 & 12 & 3 & 0 & 0 & 24 & 48.2 & 1.82 & 366 & 69.4 & 4.82 & 0 & 2 & 0.11 \\
\hline 3 & 13 & 4 & 2 & 1.94 & 4 & 6.3 & 15.59 & 220 & 45.5 & 4.55 & 0 & 3 & 0.61 \\
\hline 3 & 14 & 1 & 0 & 0 & 2 & 1.73 & 1.28 & 561 & 108.3 & 6.61 & 0 & 0 & 0 \\
\hline 3 & 15 & 1 & 0 & 0 & 2 & 8.4 & 4.08 & 337 & 62.4 & 0.79 & 0 & 0 & 0 \\
\hline 3 & 16 & 0 & 0 & 0 & 1 & 0.8 & 1.44 & 306 & 57.5 & 0.94 & 0 & 2 & 0.71 \\
\hline & Totals & 337 & 346 & 2265.67 & 239 & 995.33 & 723.32 & 3619 & 750.16 & 78.88 & 11 & 141 & 84.82 \\
\hline
\end{tabular}

Table 7-17. Vertical Distribution of Artifacts and Ecofacts in Block 2, 41MM341

\begin{tabular}{|c|c|c|c|c|c|c|c|c|c|c|c|c|}
\hline \multirow[b]{2}{*}{ Zone } & \multirow[b]{2}{*}{ Level } & \multirow{2}{*}{$\begin{array}{c}\text { Chipped } \\
\text { Stone } \\
\mathbf{N}\end{array}$} & \multicolumn{2}{|c|}{ FCR } & \multicolumn{2}{|c|}{$\begin{array}{c}\text { Mussel Shell } \\
\text { Umbo }\end{array}$} & \multirow{2}{*}{$\begin{array}{c}\text { Mussel Shell } \\
\text { Fragments } \\
\text { Wt } \\
\end{array}$} & \multicolumn{2}{|c|}{ Snail Shell } & \multirow{2}{*}{$\begin{array}{c}\text { Snail Shell } \\
\text { Fragments } \\
\text { Wt }\end{array}$} & \multicolumn{2}{|c|}{ Bone } \\
\hline & & & $\mathbf{N}$ & Wt & $\mathbf{N}$ & Wt & & $\mathbf{N}$ & Wt & & $\mathbf{N}$ & Wt \\
\hline 1 & 1 & 2 & 6 & 92.46 & 0 & 0 & 0 & 1 & 0.1 & 0 & 0 & 0 \\
\hline 1 & 2 & 1 & 0 & 0 & 0 & 0 & 0 & 0 & 0 & 0 & 0 & 0 \\
\hline 1 & 3 & 0 & 0 & 0 & 0 & 0 & 0 & 0 & 0 & 0 & 0 & 0 \\
\hline 1 & 4 & 0 & 10 & 124.59 & 1 & 2.2 & 0 & 26 & 4.5 & 0.35 & 1 & 0.1 \\
\hline 2 & 5 & 5 & 415 & 644.53 & 3 & 9.4 & 2098.79 & 8 & 3.5 & 1.88 & 29 & 34.58 \\
\hline 2 & 6 & 21 & 2099 & 4418.37 & 7 & 34.3 & 10.18 & 29 & 21 & 2.89 & 6 & 1.99 \\
\hline 2 & 7 & 9 & 481 & 3274.92 & 4 & 14.1 & 1.26 & 29 & 8 & 3.37 & 6 & 3.58 \\
\hline 2 & 8 & 13 & 44 & 57.97 & 2 & 6.4 & 4.91 & 102 & 22.7 & 1.44 & 6 & 0.95 \\
\hline 3 & 9 & 53 & 47 & 175.25 & 35 & 226.6 & 76.21 & 68 & 14.3 & 1.42 & 9 & 3.7 \\
\hline 3 & 10 & 151 & 19 & 7.8 & 13 & 63.8 & 35.32 & 260 & 51.4 & 2.63 & 7 & 4.94 \\
\hline 3 & 11 & 75 & 5 & 3.5 & 2 & 22.2 & 0.29 & 370 & 74.2 & 5.58 & 1 & 0.059 \\
\hline 3 & 12 & 53 & 1 & 0.17 & 3 & 8.8 & 4.68 & 324 & 60.3 & 8.44 & 16 & 14.7 \\
\hline 3 & 13 & 35 & 1 & 1.83 & 5 & 26.5 & 20.87 & 213 & 42.8 & 5.39 & 13 & 3.4 \\
\hline 3 & 14 & 6 & 1 & 0.47 & 10 & 14.6 & 8.62 & 136 & 29 & 3.96 & 5 & 0.43 \\
\hline 3 & 15 & 9 & 9 & 128.02 & 18 & 43.5 & 22.34 & 11 & 2.1 & 0.83 & 3 & 0.07 \\
\hline 3 & 16 & 6 & 3 & 11.65 & 7 & 9.2 & 13.68 & 172 & 36 & 0.65 & 1 & 0.03 \\
\hline & Total & 439 & 3141 & 8941.53 & 110 & 481.6 & 2297.15 & 1749 & 369.9 & 38.83 & 103 & 68.529 \\
\hline
\end{tabular}




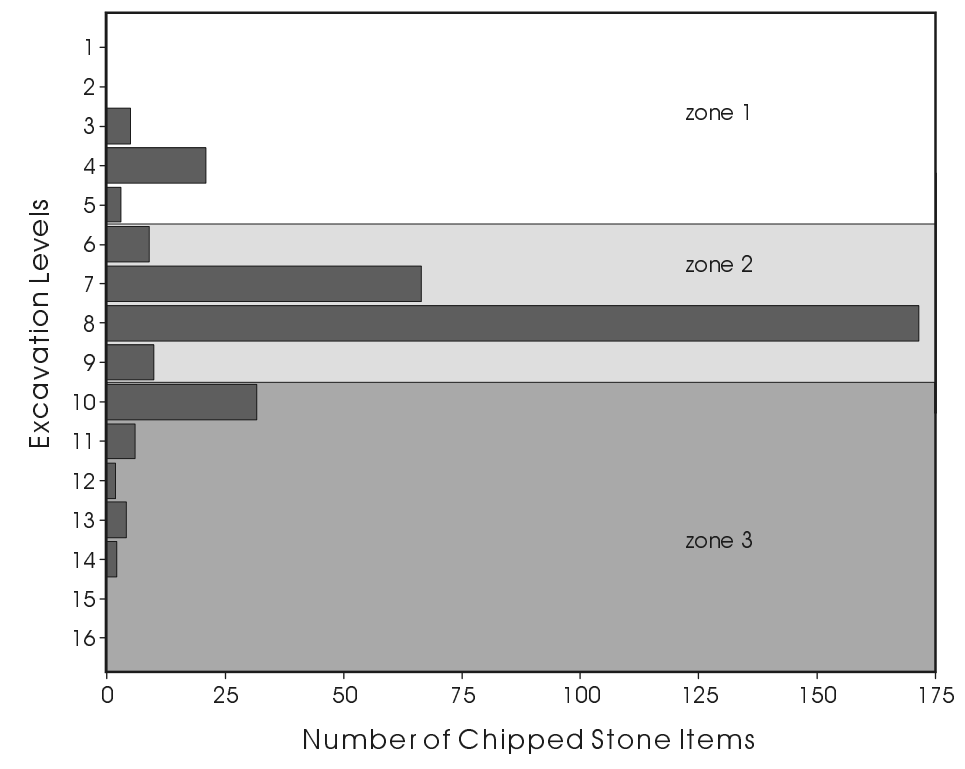

Figure 7-21. Distribution of chipped stone items by zone in Block 1 at 41MM341.

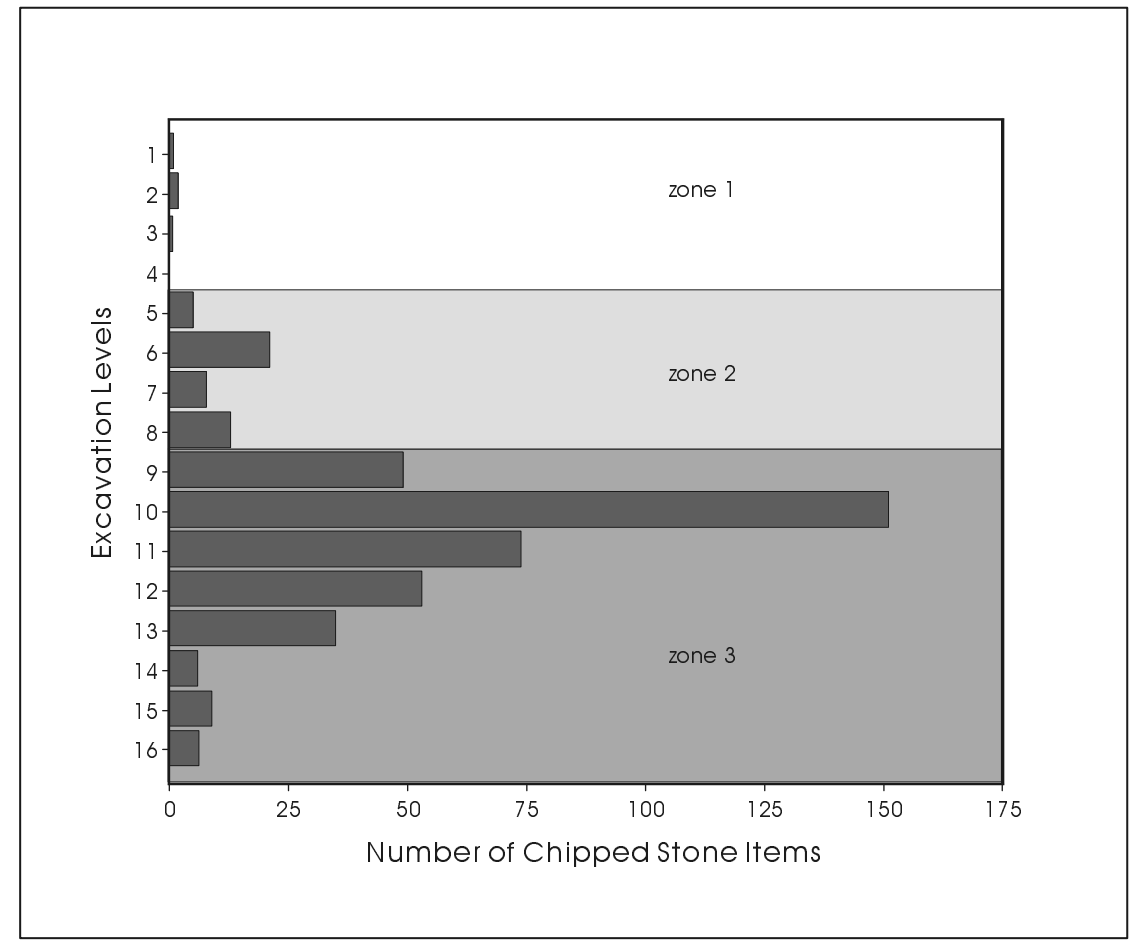

Figure 7-22. Distribution of chipped stone items by zone in Block 2 at 41MM341. 
Phase occupation debris seems to be concentrated in the vicinity of Block 1. During the Austin Phase, the eastern edge of the site may have been used as a generalized discard area, while the western margin of the site may have been reserved for cooking activities associated with maintained facilities. Judging from the differences in material densities between the two blocks, differences in the use of space may also have existed during the Late Archaic II occupation of Zone 3.

\section{Debitage Analysis}

All unmodified debitage recovered from the two blocks at 41MM341 has been categorized in terms of corticate (i.e., primary and secondary) and decorticate (tertiary) specimens. A comparison of relative proportions of these two categories can identify differences in stages of reduction either between or within blocks and between the three cultural zones of the site.

Based on the distribution of the major artifact categories in Blocks 1 and 2, three zones were distinguished. Radiocarbon assays and chronologically sensitive artifacts found within these zones strengthen the conclusion that these zones are distinct archaeological components. The breakdown of cortex categories within the debitage sample from Block 1 indicates that the percentage of entirely decorticate debitage increases with increasing depth of the zones (Table 7-18). That is, Zone 1 has the lowest percentage of decorticate debitage ( 66 percent), while Zone 3 has the highest (74 percent). Roughly the same pattern is noted in the debitage sample from Block 2 (Table 7-19). Only three flakes were encountered in Zone 1 of the block, but in Zones 2 and 3, where sample sizes are adequate ( $n=47$ and $n=383$, respectively), the increased percentage of decorticate debitage is clearly evident with increasing depth.

Overall, the percentage of decorticate debitage in the two blocks is not unlike those noted in the 41MM340 debitage samples. At this point, insufficient data exists to determine whether the trends noted in the two blocks of 41MM341 are due to behavioral differences regarding lithic reduction strategies or the impacts of depositional, site formation, processes. If due to behavioral factors, these patterns would reflect an intriguing trend through time associated with the degree of reduction of tools manufactured and/or rejuvenated on site. If depositional in nature, the patterns may have some important impacts on the artifact assemblages associated with each zone.

Table 7-18. Percentage of cortex categories in Block 1, 41MM341

\begin{tabular}{|c|c|c|}
\hline Zone & Corticate & Decorticate \\
\hline 1 & 34 & 66 \\
\hline 2 & 30 & 70 \\
\hline 3 & 26 & 74 \\
\hline
\end{tabular}

Table 7-19. Percentage of cortex categories in Block 2, 41MM341

\begin{tabular}{|c|c|c|}
\hline Zone & Corticate & Decorticate \\
\hline 1 & 67 & 33 \\
\hline 2 & 32 & 68 \\
\hline 3 & 27 & 73 \\
\hline
\end{tabular}




\section{Vertebrate Faunal Material}

Barbara A. Meissner, Center for Archaeological Research, The University of Texas at San Antonio provided analyses of vertebrate faunal material recovered from the two excavation blocks at 41MM341 (Appendix C). According to her report, the predominantly fragmented bone is generally in moderate to good condition, with four genera of mammals and three genera of reptile identified. The majority of the unidentified bone appeared to be from animals of the deer/antelope size category. Additionally, highly fragmented, unidentifiable specimens of bird and turtle were present. There is little evidence of extensive atmospheric or chemical weathering, suggesting clayey, fluvial deposits buried the material shortly after initial fragmentation and subsequent deposition. Overall, a relatively small amount of faunal material was encountered within this otherwise rich, cultural deposit. In addition, a majority of the bone encountered is highly fragmented, suggesting the material was heavily processed. Further analyses may provide a clearer interpretation of the relative paucity of remains and the extent to which the remains present were processed.

\section{Mussel Shell}

Robert G. Howells conducted analyses of freshwater mussel specimens recovered from the shell lens encountered in Block 1 at 41MM341 (Appendix D). Forty-nine specimens selected to show the variability in species present in Block 1 were submitted for analysis. According to his report, all specimens were in very good condition, with four species identified, representing the Family Unionidae. Threeridge (Amblema plicata) represented roughly one-third of the sample; smooth pimpleback (Quadrula houstonensis) represented nearly 60 percent of the sample; with southern mapleleaf (Quadrula apiculata) and Tampico pearlymussel (Cyrtonaias tampicoensis) comprising the fractional remainder. Comparison of this assemblage with modern collections from the Central Brazos River Drainage mirrors the regional climatic trend toward a more arid environment exhibited by the change in mussel population at 41MM340. Similarly, all the taxa represented in the archaeological assemblage evolved in flowing waters and are most often associated with gravel, stable sand, and mud substrates in permanent-water conditions. These data suggest the site was formerly in relative close proximity to a perennial stream; possibly a former meander of the Little River.

\section{Macrobotanical}

J. Philip Dering, Associate Director for Macrofossil Analyses, Paleoethnobotany Laboratory, Texas A\&M University performed macrobotanical analyses of a single flotation sample recovered from the shell lens encountered within Block 1. According to his report (Appendix E), the archaeobotanical assemblage, both in quantity and size of the material, is very reduced. Of the sample submitted for analysis, only 6 very small $(<2 \mathrm{~mm})$ thin nutshell fragments of an indeterminate species (cf. pecan) were encountered. Due to the overall paucity of botanical remains exhibited in the general level samples submitted, future analyses should be directed toward samples recovered from heating features and the samples collected from radiocarbon dating, both of which are conducive to the preservation of botanical materials and may yield larger identifiable specimens.

\section{Pollen and Phytolith}

Analyses of pollen and phytolith samples extracted from the shell lens present in Block 1 were performed by John G. Jones, Associate Director for Pollen Analyses, Palynology Laboratory, Texas A\&M University (Appendix F). Pollen and phytolith specimens were noted within the samples submitted, however, the overall state of preservation was poor. The pollen concentration value for the single cultural zone is 1,694 grains $/ \mathrm{ml}$. Environmental factors such as cyclic wetting and drying in combination with the acid soils of the region are not conducive to the preservation of pollen or phytoliths, and, as such, the overall yield, or concentration value of the individual samples do not lend themselves to reliable interpretations. 


\section{Land Snail Shell}

Richard W. Fullington conducted analyses of two gastropod samples extracted from the shell lens in Block 1 (Appendix G). The samples consisted of specimens collected from floated light and heavy fractions and those specimens obtained from $1 / 4$-inch water screening. According to his report, all specimens were in excellent condition, with eleven species identified, representing eight families. When the sample of gastropods is divided into their respective preferred habitat types, it becomes evident that species preferring a moist, densely wooded setting greatly outnumber $(\mathrm{n}=168 ; 86$ percent) those inhabiting open or sparsely wooded settings ( $n=29 ; 14$ percent). The species represented suggest similar environmental conditions to those encountered in Zone 4 at 41MM340. A notable exception, the presence of Anguispira alternata, suggests the presence of exposed, wooded limestone outcroppings within the vicinity. The gastropod shells examined appear to be deposited in situ and not from fluvial transport. The relatively low number of species present and the occurrence of only one species of aquatic gastropod qualify this. Additionally, the presence of the predatory snail, Haplotrema concavum, is indicative of a stable and long-term gastropod community, occurring only within large populations of land snails. In comparison with 41MM340, there appears to be little difference in the frequency of specimens encountered among the cultural zones. These data suggest that the single cultural zone represents a relatively short time span with a low snail population density.

\section{Diatom}

Barbara Winsborough, of Winsborough Consulting, conducted analyses on two diatom samples collected from site 41MM341 (Appendix H). One sample was collected from the sediment matrix comprising the shell lens exhibited in Block 1. A second sample, consisting of fired clay nodules, was collected from a hearth feature extending just beneath the shell lens in the same block. While there appeared to be sufficient freshwater mussel shell present in proximity to a hearth feature to mirror the diatom assemblage recovered from 41MM340, evidence of diatoms was absent from each of these samples. This differential preservation exemplifies the higher probability of recovering diatom populations from fired clay nodules that may tend to seal in and preserve silica diatoms preventing them from entering back into solution in these types of silicapoor soils.

\section{Summary}

Our limited testing in the two blocks at 41MM341 suggests that three distinct cultural zones may be present. These zones are defined by dramatically different densities of chipped stone and fire-cracked rock. These differences are supported by different types of diagnostic artifacts and different frequencies of features. Radiocarbon dates support these distinctions. A radiocarbon date from Zone 1 suggests an occupation data of around A.D. 1407-1440, a period that corresponds with a Toyah Phase component. Zone 2 has two radiocarbon dates, one that spans A.D. 1020-1160 and one that has a range of A.D. 685-780. These dates suggest that this zone spans the Austin Phase. Finally, while we lack any radiocarbon dates for the Zone 3 material, it is clearly manifested in both blocks by large increases in chipped stone. The recovery of several diagnostic artifacts suggests that this occupation may date to the Late Archaic II period. 


\section{Chapter 8: Recommendations}

\section{Site Eligibility}

\section{$41 M M 340$}

Site 41MM340 is interpreted as a prehistoric multicomponent open campsite located above and within various alluvial straths deposited atop a sandy pointbar along the left descending bankline of a probable former meander of the Little River. In support of this interpretation, core boring results from the 1930s suggest that a relatively wide channel cut through the underlying strata at depths over $10 \mathrm{~m}$ below current ground surface within approximately $30 \mathrm{~m}$ of the site. Nine different zones are visually identifiable in the two excavation blocks in the southern portion of the site, as expressed within the rights-of-way.

Within each block and between blocks there is significant variation in thickness of all zones. The degree to which they are identifiable and separable during excavation varies. The dating of the upper and lower portions of the four cultural zones with the highest artifact density within and across the two blocks in the southern portion of the site indicates that, while accumulation rates vary, several zones have accumulated so rapidly that the dates are statistically distinguishable. Furthermore, the only zones that can be shown to be statistically different from each other, in terms of dates, are Zone 2 and Zone 8, the upper most and lowest cultural zones. Nonetheless, the relatively large series of radiocarbon assays run on material from the site have established that the approximately $130-\mathrm{cm}$ thick vertical column probably represents less than approximately 1,100 years of prehistoric occupation. Overall, the cultural material recovered from this portion of the site is rich and contains archaeological assemblages highly relevant to the investigation of Late Archaic I and Late Archaic II Period cultural adaptations within this region.
The separation of the site into northern and southern sections is justified by the presence of an apparent former slough bisecting the midsection of the surveyphase-delimited site bounds. Results of auger borings identified an approximately $20-\mathrm{m}$ wide sterile corridor separating the two sections; a distance typically regarded as grounds for determination of separate sites, especially with the probability of a dynamic stream dissecting the former landscape. It is equally possible, however, that the single component exhibited in the northern section of the site was at one time a portion of at least one of the components of the southern section of the site. Based solely upon the radiocarbon dates, the contemporaneity of the feature in Block 1 with Zone 6 in Blocks 2 and 3 is evident. In addition, while Block 1 was excavated in arbitrary $10-\mathrm{cm}$ levels, the distribution of chipped stone by level clearly indicates two, and possibly three, peaks that may reflect similar, though less visible, occupation zones.

Based on artifact content and geomorphic characteristics all cultural zones could be visually identified and may be correlated across both southern blocks (Blocks 2 and 3) at 41MM340. In general, the zones share similar proveniences below ground surface. Nonetheless, even within the same block vertical variation due to the undulating surfaces, and truncation and merging of some zones made it difficult, at times, to follow a zone across the entire block. Zone 2 is expressed as a shell midden throughout Block 3 and the same zone may be manifested in the western portions of Block 2 . Zone 4 is expressed as a fire-cracked rock scatter throughout both blocks. A similar fire-cracked rock scatter with a greater concentration of freshwater mussel shell comprises Zone 6. Zone 8 is expressed as a scattering of fire-cracked rock with a relative abundance of lithics and a sparse scattering of freshwater mussel shell. Zones 3, 5, and 7 are, in turn, characterized by lower densities of chipped stone, fire-cracked rocks, mussel shell, and a lack of fea- 
tures. The analysis of the radiocarbon dates, discussed in Chapter 7, indicates that in Block 2, the upper portion of Zone 2 is indistinguishable from the lower part of the same zone, as well as from the upper and lower portions of Zone 8. In Block 3, the upper and lower portions of Zone 2 are statistically different from Zones 4 and 6, but these two zones are indistinguishable from each other. Finally, Zone 8 is statistically different from all overlying zones.

These patterns suggest that cross-dating of the zones between the two blocks of the site might not be a simple matter. They also suggest that some degree of vertical mixing may have occurred between the zones. The results of the extensive amino acid racemization analyses conducted on snails and mussel shell from the various cultural zones also hints at this possibility. The analysis of A/I ratios for a sample of two species of snail shells (Polygyra mooreana and Praticolella berlandieriana) and two species of mussel shells (Tritogonia verrucosa and Amblema plicata) also suggests some movement of material between zones.

In summary, it is the opinion of the authors that, in general, site 41MM340 contains several clearly distinguishable cultural zones with high research potential. Furthermore, testing has demonstrated that isolated segments of the site may potentially contain a number of visually and analytically separable components accumulated over short time periods. Therefore, it is the recommendation of CAR that site 41MM340 be nominated for inclusion in the National Register of Historic Places (NRHP). Specifically, the degree of finegrained temporal resolution afforded by the deposits of the site, as well as their potential to allow the reconstruction of paleoclimatic conditions and the investigation of changes in human adaptation over short time periods rarely seen in other archaeological sites in the state, strongly argues for recommending the site to the NRHP (36 CFR 60.4 Criterion (d)).

\section{MM341}

Site 41MM341 is similarly interpreted as a prehistoric multicomponent open campsite located above and within various alluvial straths deposited along the right descending bankline of a probable former meander of the Little River. Auger boring results have indicated a relatively large single areal concentration of materials within the rights-of-way. These limits fall between two extant sloughs and, according to the 1930 s core borings, immediately south of a former large stream, probably a meander of the Little River. A single cultural occupation zone is evident in both Blocks 1 and 2 , as expressed within the rights-of-way. In addition, a discrete later component is apparent in the upper portion of Block 1, and a possible discrete earlier component is suggested in the lower portion of Block 2 . Further, the three radiocarbon assays have suggested a relatively clear resolution of the chronology within the vertical column for the approximately 750 to 800 years of prehistoric occupation. The cultural materials recovered from the site moderate and contains an archaeological assemblage complementary to the interpretation of the later part of the Late Archaic II and both phases of the Late Prehistoric Period within this region.

The upper, discrete component identified in Block 1, consisting of small pit features and aboriginal pottery, was probably truncated by the mechanical stripping of $3 / 4$ of the block prior to manual excavation. The corrected and calibrated radiocarbon date, with a 1 sigma range of A.D. 1407 to 1440 , combined with the presence of ceramics, suggests a possible Toyah Phase component (Prewitt 1981:83), worthy of further investigation. The underlying shell lens within the same block also provides a convenient correlation between the radiocarbon date and the Scallorn arrow point, suggesting the earlier Austin Phase of the Late Prehistoric Period (Prewitt 1981:82). The large hearth feature encountered in Block 2 provided a radiocarbon date with a 1 sigma range of A.D. 1020 to 1160 and was underlain by a Friday biface, a contemporaneous knife temporally contained within the Austin Phase (Prewitt 1981:82). In addition to these feature-rich zones, the underlying artifact peak at $100-110 \mathrm{~cm}$ bs may date to the Late Archaic II and may also be worthy of further analysis.

Through synthesis of the radiocarbon dates and analyses of the few diagnostic artifacts, the individual components of 41MM341 suggest a moderate to high level of temporal integrity, with minimal bioturbation evident. However, the reconstruction of the paleoenvironment 
for the site will be difficult, at best, without the aid of typical climatic indicators. Special analyses conducted for the presence and identification of diatom, pollen, phytolith, and macrobotanicals have all returned somewhat limited results. The strategy employed for preliminary analyses focused upon the cultural zones, or occupation surfaces themselves, rather than the individual features encountered within the zones. While the radiocarbon dates have provided a relatively clear and tight chronology for the site, a different strategy specifically addressing investigation of the features contained within the cultural zones must be employed for interpretation of the site, climatically as well as temporally.

In conclusion, it is the opinion of the authors that 41MM341 exhibits such qualities and overall temporal integrity to be eligible for inclusion in the National Register of Historic Places (NRHP). Specifically, evaluative consideration in regard to temporal integrity and the ability to provide significant data for reconstruction of past environments provide for recommending NRHP eligibility of 41MM341 (36 CFR 60.4 Criterion (d)). 



\section{Chapter 9: Data Recovery Plan}

\section{Data Types and Research Issues}

The following data types have been recovered from the test excavations at 41MM340 and 41MM341: chipped lithics, burned rock, mussel shell, snail shell, large quantities of charred macrobotanical remains, diatoms and small quantities of pollen and phytoliths. The general characteristics of these data types and the research questions that can be addressed with them are discussed below.

\section{Paleoenvironmental Data}

The review of the existing data and reconstructions of the paleoenvironmental conditions characterizing the last 3,000 year period of the occupations of 41MM340 and 41MM341 indicates that this period was characterized by oscillations between moist and dry periods of various duration. Based on the microfauna from Hall's Cave a wet period characterizes the period between about 3200-1000 BP, with moisture levels reaching their peak between about 2500-1300 BP (Collins 1995). Based on data from Boriack and Weakly Bogs, Bousman (1998) reconstructed the estimated arboreal canopy cover throughout the Late Holocene. This reconstruction shows a period of increased arboreal canopy cover -typically associated with increased effective moisture levels- between 3500-3000 вP. Drier conditions characterize the period between 3000-2200 BP with moisture levels bottoming sometime around $2500 \mathrm{BP}$. This period is characterized by grassland vegetation communities. Effective moisture levels appear to increase thereafter reaching a peak between 1700-1900 BP, and correspond to an increase in the arboreal canopy. Between 1600-1300 BP, effective moisture levels appear to drop again and grasslands appear to increase in extent at the expense of woodlands. Although the Boriack and Weakly bog data indicate a slight increase in effective moisture levels between about 1200-800 BP, the associated vegetation communities of the time period remain dominated by grasslands although some expansion of woodlands into valley-proximate uplands may have occurred. Following another decrease between 800-500 BP, moisture levels increase substantially resulting in the return of woodlands into modern times.

One of the most important features of these oscillations is their impact upon the local and regional resource base available to hunter-gatherers. Throughout prehistory plant resources have always played a significant role in hunter-gatherer subsistence. However, with the exception of the origins of food production, archaeologically in Texas the most visible and best documented shifts in prehistoric huntergatherer subsistence strategies appear to be correlated with the increase of hunting and the role of animal protein in prehistoric diets (e.g., Toyah). It is perhaps because of the impact of such shifts on land use, subsistence strategies, and technological organization that these shifts are more recognizable in the archaeological record.

The changes in paleoclimatic conditions outlined above affected the range and productivity of prairie and woodland vegetation exploited by prehistoric hunter-gatherers. In addition, they also affected the range and density of animal species available for human consumption. Most importantly, changes in effective moisture levels have impacted the productivity of the grassland communities on the Blackland Prairie and the neighboring Post Oak Savanna.

Although some disagreement exists, greater effective moisture levels appear to have favored the return of large numbers of bison into Central Texas and onto the Blackland Prairie. Reconstructions of regional populations (Dillehay 1974; Collins 1995) indicate that bison were present in Texas during the middle to late portion of the Late Archaic until approximately 1600 BP. In contrast, bison remains become scarce during the very late portion of the Late Archaic when Darl projectile points are in use and this scarcity continues throughout the Austin Phase of the Late Prehistoric period. The Late Archaic period of bison 
presence appears to correlate well with higher effective moisture levels within the region. Similarly, the extended period of bison scarcity that appears to be present during the Austin Phase of the Late Prehistoric period also appears to correlate with low levels of effective moisture as evidenced from the Patschke Bog core (Camper 1991).

More detailed knowledge regarding the paleoclimatic conditions characterizing the 700-1000 year period reflected in the occupation zones at 41MM340 and the broader 2500 years that include the last occupation of 41MM341 will allow greater precision in modeling the changes in the nature and structure of the resources that were potentially available in the immediate vicinity of the sites and in the neighboring vegetation communities.

One research direction that could aid in the reconstruction of paleoenvironmental conditions in the vicinity of the sites and on the floodplain in general is a systematic documentation of flood frequencies associated with the Little River during the occupation of the two sites. Potentially the best location to pursue this is in either of the two sloughs found in the vicinity of the sites. In the same vein, a thorough comprehension of the history of the Little River floodplain where sites 41MM340 and 41MM341 are located may provide a better understanding.

Although the snail samples analyzed by Fullington (Appendix $\mathrm{G}$ ) represent relatively small proportions of the available sample, and only a small proportion consists of the "micro" snails derived from the light and heavy fractions acquired from flotation, some intriguing differences in population composition are notable through time. For instance, grouping the snail samples from 41MM340 by the preferred habitat types provided by Fullington indicates a trend from a dominance of snail populations by open grassy/sparsely wooded species (98.4 and 63.9 percent in Zones 8 and 6 , respectively), to a shift to moist densely wooded habitat species in Zone 4 (84 percent). The Zone 2 snail population only contains species tolerant of open grassy/sparsely wooded habitats. In addition, two specimens of Praticolella berlandieriana, a specie that prefers benched terrace type settings with early succession emergent vegetation, was present in the largest of the snail sample from Zone 8. Interestingly, a single specimen of Haplotrema concavum, a predatory species indicative of stable long-term gastropod populations, is present in Zone 6. Its presence suggests that snail populations remained large throughout the time Zones 6 and 8 were occupied. The snail population from 41MM341, occupied some 850 years after the terminal occupation of $41 \mathrm{MM} 340$, is dominated by species preferring dense woody cover. This shift compared to the Zone 2 population at $41 \mathrm{MM} 340$ suggests an additional change in vegetation communities.

It is likely that the composition of the snail populations by preferred habitat type reflect both macroregional climatological conditions and changes in plant community composition and structure in the immediate vicinity of the two sites. The presence of Praticolella berlandieriana in combination with the large Rabdotus population may reflect the initial stages of stabilization of the floodplain (i.e., decreased frequencies of flooding), the early stages of plant invasion, and the filling in of this newly available niche by a large colonizing snail population. The appearance of the predatory snail species may be in response to the exploding colonizing population sizes within this new niche. The decreased proportion of open grassy/sparsely wooded habitat species in Zone 6 , and the dominance of densely wooded habitat species in Zone 4 may reflect the gradual emergence of a stable floodplain with a riparian woodlands vegetation. The shift back to exclusively open grassland/sparsely wooded habitat species in Zone 2 may be a reflection of regional scale decreases in effective moisture, and the resulting thinning out of the woody component of the vegetation. The 41MM341 snail population may indicate yet another oscillation in climate conditions or vegetation succession on the Little River floodplain.

Although this preliminary reconstruction of paleoclimatic contexts is based on a very small sample, it is clear that a systematic study of fully representative samples from both 41MM340 and 41MM341 can provide valuable information both towards an assessment of the model described above, as well as a more detailed understanding of floodplain dynamics within the vicinity of the two sites. 
A number of specific research issues relevant to the reconstruction of paleoenvironmental conditions can be defined based on the preceding discussion. They include, but are not limited to, the following:

1) What are the paleoenvironmental conditions characterizing the roughly 3,000 year period encompassing the spans of occupation of the two sites?

2) Is there a shift from predominantly grassland to floodplain forest conditions during the early portion of the Late Archaic I as reflected at 41MM340?

3) What is the history of the Little River floodplain in the vicinity of the two sites and how does it relate to the occupation histories of the sites?

4) What can we learn from the geomorphological history of the Little River floodplain that can aid in future assessments of the likelihood of preservation of historic properties in similar contexts?

5) What shifts, if any, occurred in the Prairie/ Post Oak Savanna boundary during the 3,000 years the two sites were occupied?

\section{Subsistence Data}

Almost 1,500 pieces of bone have been recovered in addition to about 6,770 mussel shell umbos and over 22,500 whole snail shells from 41MM340. In addition, three out of four macrobotanical samples yielded pecan and/or hickory nutshell fragments. Site 41MM341 yielded 244 pieces of bone, 349 mussel shell umbos, and over 5,300 whole snail shells. The single macrobotanical sample produced nutshell fragments. The condition of all of the faunal remains is exceptional, indicating that differential preservation conditions are not the primary factors responsible for the composition of these samples. The condition of the remains also indicates that depositional and preservation conditions are favorable for the recovery of additional materials in these classes. The rate of recovery of nut shell remains ( 3 out of 5 samples; 60 percent), suggests that edible plant remains (e.g., pecan, hickory) may be common in the $84{ }^{14} \mathrm{C}$ samples containing the largest macrobotanical remains and the
80 light and heavy fraction samples recovered from the two sites.

Preliminary analysis of the vertebrate bone from the two sites suggests that the bulk of bone represents deer and antelope-sized animals. In addition, based on cortical thickness, only two small fragments may be from bison/cow-sized animals. The diversity of vertebrate taxa (fish, turtle, rabbit, possum, raccoon, bird, antelope/deer), and the presence of moderate numbers of mussel shells suggests a wide diet breadth. The addition of pecan nuts and likely other plant species to the diet further extends the diversity of diet. The small size of the mammalian bone may also be considered as a possible indicator of some degree of subsistence stress. Both aspects of the subsistence remains are somewhat surprising given the likelihood that bison populations were present and exploited throughout Central Texas and presumably on the Blackland Prairie particularly during the approximately 700 years encompassed by the $41 \mathrm{MM} 340$ occupation zones and during the last occupation zone (Toyah Phase) present at $41 \mathrm{MM} 341$.

The scarcity or perhaps entire lack of bison remains at the two sites is surprising given the generalized impression gained from the Late Archaic Central Texas archaeological record. It is also surprising given the generalized assumption from optimal foraging that if bison was ever encountered by local populations it would have been pursued given its high ranking. Numerous factors may account for the composition of the faunal assemblages recovered from the two sites. They include, but are not limited to, the following:

1) The effects of transportation costs on skeletal element representation;

2) The impact of food processing techniques on skeletal elements;

3) Site functional considerations;

4) Site structural considerations;

5) The absence/scarcity of bison within the region; and

6) Regional land use strategies that do not extend out onto the Blackland Prairie and do not rely on bison procurement. 
A number of specific research questions can be generated relating to these factors and potential subsistence strategies employed by site inhabitants. They include, but are not limited to, the following:

1) Were the inhabitants of the two sites bison hunters?

2) Do the isolable components present at the site represent "out-of-hunting season" occupations when groups subsisted on lower ranked resources?

3) What was the proportional contribution of terrestrial fauna, flora, and freshwater resources to the diet?

4) Were there oscillations in the proportional contribution of these resources to the diet over time (i.e., between the cultural zones present at the two sites)?

5) Does the fragmentation of the animal bone reflect dietary stresses or the impact of transportation limitations?

\section{Chipped Lithics}

A total of 9,545 chipped lithic artifacts was recovered from 41MM340. Site 41MM341 yielded 776 chipped lithics. The large majority of these consist of unmodified lithic debitage. Only nine projectile points have been recovered and the preliminary sort of the lithic artifacts resulted in the identification of only nine nondebitage lithic artifacts consisting of a Friday knife, a bifacial knife fragment, a biface manufacture failure, two Erath bifacial adzes, a cobble tool, a nutting stone, and a hammerstone.

The chipped lithic artifacts recovered during testing and those to be recovered during data recovery will be critical in investigating three main research issues and directions:

1) Range of activities carried out at the site;

2) The technological organization of the huntergatherers, this also reflects on larger scale offsite land use organization; and

3) Regional and cultural relationships between Central and East Texas.
The degree to which collections of lithic debitage and stone tools can be used to answer these issues will depend in part on how clearly distinct components can be identified within sites. This, in turn, will depend on the dating of the components, the distribution of diagnostic artifacts, and information derived from snail and mussel shell racemization on disturbances and deposition rates by component. Nonetheless, the integrity, and by extension the research potential of each component within the sites and each site as a whole, should be seen as highly dependent on the research questions and issues being asked or pursued. That is, all sites have the potential to contribute scientific knowledge, given selected research issues and questions. The goal of the more comprehensive research design, to be developed at a later date, is to define specific and detailed research questions and data types relevant to addressing them.

For some questions, sites situated at the high end of the integrity continuum are critical, but for other questions, sites that traditionally are viewed as having low integrity, are critical. Unmodified lithic debitage is helpful in informing about the nature of the tool manufacture activities carried out at these sites (e.g., early, middle, and late reduction, tool rejuvenation, etc.), the reduction strategies employed (bifacial, core reduction/ blade-flake production), and the raw material procurement and transport strategies (e.g., local vs. non-local raw materials, core preparation activities, etc.) used by the site inhabitants. The presence of abundant, good quality lithic resources within the current channel of the Little River suggests that no matter where the prehistoric stream channel may have been, it served as a reliable source of raw materials. Therefore, it is expected that the majority of the lithic materials found on site would be of local origin. Nonetheless, given that finished tools and blanks manufactured in other parts of the annual range would have been brought onto the site, it is also expected that a small proportion of lithic debitage, of the smaller size range, would be of non-local origin. Whether these specimens can be identified would depend on the similarities in raw materials to those present within the gravel bars of the Little River.

The composition of the tool assemblages recovered from the site should help identify the range of activities carried out by the site occupants, as well as contribute to the understanding of overall site function 
within the broad land use system. For instance, the preponderance of manufacture failed vs. use broken tools should suggest that lithic activities were oriented towards some degree of gearing up in anticipation of future needs. In contrast, the predominance of use failed specimens should be more characteristic of retooling activities typically associated with tool maintenance carried out by foragers. Similarly, the proportion of formal vs. expedient and minimally retouched tool forms may be indicative of degree of mobility within the annual cycle or the degree of processing requirements experienced by the tool users.

One of the emerging research questions in Central/ East Texas archaeological research has been the definition of the place of east-central Texas in the land use strategies of East and Central Texas huntergatherer populations. Results of archaeological research in the region have for a long time suggested that the material culture present in the area showed a great deal of affinity to Central Texas in terms of projectile point types. These patterns are also confirmed by the distribution of projectile point types across these regions (Prewitt 1995). In addition, while a large proportion of the Late Archaic points and tool forms in Central Texas are manufactured of locally available fine-grained cherts, some Late Archaic tool forms characteristic of East Texas are consistently made on fine-grained quartzites and/or petrified wood (e.g., Gary projectile points, Wooden points, Harvey bifaces, Bronson bifaces).

The breakdown of tools and debitage into raw material types may provide one gauge to measure the presence of cultural traits that are typically considered as deriving from one or another of these regions. This information may, in turn, reflect on whether the site is employed by hunter-gatherer groups from the Edwards Plateau or East Texas groups moving onto the Blackland Prairie or perhaps a mixture of both reflecting some type of communal activity relationships.
Based on the previous discussion, a series of specific research issues can be suggested:

1) Do the lithic assemblages recovered from the isolable components of the two sites reflect broad ranges of activities characteristic of long-term occupations, or a narrow range of activities more likely to have occurred on special activity sites?

2) Are there changes in assemblage composition between the isolable cultural zones and do they reflect technological adaptations to shifting resource bases?

3) Do the assemblages recovered from the distinct cultural zones reflect contemporary occupations by East Texas and Central Texas cultural groups?

4) Are there distinct artifact classes in the assemblages from the two sites that can be used to reconstruct territorial ranges, and what were the territorial ranges of the sites' inhabitants?

5) Are the ceramics recovered from $41 \mathrm{MM} 341$ more typical of Toyah Phase specimens or do they belong with other East Texas cultural units?

6) Given the fine-grained control afforded by the isolable cultural zones, is it possible to refine the projectile point sequences of the Late Archaic I and II as they pertain to the Central Texas/East Texas archaeological regions? 


\section{Methodology}

\section{MM340}

Extensive excavation of auger borings revealed two distinct areal concentrations of cultural material, separating the site into northern and southern sections by an approximately 20 -m wide east-west corridor. The northern section of the site contained a relatively thin, inconsistent zone of sparse scattering of cultural material. Conversely, the southern section revealed a relatively abundant amount of cultural material, with at least two stratified components discernible within the auger borings. Moreover, excavation of test units in the southern section revealed two additional stratified components occurring below the depths attainable by the auger, for a total of four stratified cultural deposits.

Accordingly, recommendation is made for further investigations to concentrate only upon the southern section of 41MM340 in view of the following: the four distinct stratified components, good stratigraphic correlation between the test units, and the relatively high artifact density.

Within the area of potential effect, the southern section of the site comprises approximately $450 \mathrm{~m}^{2}$. Based upon the extensive auger data recorded during the testing phase, a single areal concentration of stratified deposits has been delimited at approximately $150 \mathrm{~m}^{2}$. Further, as evidenced in the southern test excavation units, the uppermost aspect of the latest cultural zone occurs at approximately $50-60 \mathrm{~cm}$ bs. In accordance with the scope of work implemented for the testing phase, the upper $40 \mathrm{~cm}$ of recent alluvial fill can be mechanically removed without impact to the youngest component.

Focusing upon the areal concentration of stratified deposits, the three following scenarios are proposed for (1) minimum, (2) adequate, and (3) maximum feasible data recovery:

\section{1) Excavation of an approximately $50 \mathrm{~m}^{2}$ grid, encompassing the southern test units.}

This strategy would target the heart of the known areal concentration of stratified components. While the ephemeral boundaries, indicated by the continuance of the stratified zones within wall profiles of the exterior test units, would not be explored, this plan would provide for minimal mitigation to investigate at least a portion of the southern section. Data recovery would thus be expected to multiply the results of the testing efforts approximately six-fold. With the terminal excavation depth of $1.6 \mathrm{~m}$, data recovery volume would equal $3,000 \mathrm{~m}^{3}$.

\section{2) Scenario 1 plus an additional $25 \mathrm{~m}^{2}$ exploratory grid.}

a) Based upon the west wall profile of BHT B, it is apparent that the most abundant continuance of the stratified components occurs to the west of the tested portion of the site. Unfortunately, this area is mantled by a substantial artificial berm, which curtailed exploratory efforts during the testing phase. The berm rises $1.5 \mathrm{~m}$ above the current ground surface and has a cross-sectional width of approximately $25 \mathrm{~m}$ at the base. While it is possible that subsurface disturbance occurred outside of the proposed ROW for the construction of the berm, it is unlikely that the ground surface currently underneath the berm (i.e., within the proposed ROW) was impacted for its construction. Thus, under this scenario, an approximately 10-m wide swath of the berm would be removed for exploratory auger boring similar to that conducted during the testing phase. The results of the auger borings would aid the identification of the continuance of the cultural strata, if any, that would condition the placement of the additional $25 \mathrm{~m}^{2}$ exploratory grid.

b) In the event that exploratory efforts fail to reveal a continuance of the cultural zones west of the site, then the additional $25 \mathrm{~m}^{2}$ exploratory grid would be absorbed by the main grid; providing a total main grid area of $75 \mathrm{~m}^{2}$. This area would suffice to mitigate an adequate portion of the delimited site bounds, as well as a majority of the known areal concentration of stratified components. Both options (' $a$ ' and ' $b$ ') under Scenario 2 would expect to yield approximately nine times the amount of material recovered during the test excavations. With the terminal excavation depth of $1.6 \mathrm{~m}$, data recovery volume would equal $6,750 \mathrm{~m}^{3}$. 


\section{3) Combination of Scenario 2-a and 2-b.}

This strategy would provide for exploratory efforts west of the site and near complete mitigation of the areal concentration of stratified components. Again, if exploratory efforts fail, then the additional $25 \mathrm{~m}^{2}$ exploratory grid would be absorbed by the main grid; providing a total main grid area of $100 \mathrm{~m}^{2}$. This large grid would adequately mitigate the areal concentration of stratified cultural material in the southern portion of the site. Data recovery would thus be expected to multiply the results of the testing efforts approximately thirteen-fold. With the terminal excavation depth of $1.6 \mathrm{~m}$, data recovery volume would equal $12,000 \mathrm{~m}^{3}$.

\section{MM341}

Extensive excavation of the auger borings revealed a delimited areal extent of cultural material approximately $875 \mathrm{~m}^{2}$ as expressed within the rightsof-way. Throughout, the site exhibited a relatively thin, inconsistent zone of sparse scattering of cultural material. Excavation of test units corroborate the results of the auger borings, with the identification of a thin midden in the eastern portion and a small complex of likely associated hearth and pit features in the western portion. As the two areas are separated by only $15 \mathrm{~m}$, it is feasible that they represent different loci of site utilization; the western portion as a primary activity area and the eastern portion as a refuse area. As such, the investigation of both areas would provide for the interpretation of site use and formation.

Accordingly, recommendation is made for further investigations to concentrate upon the proxemic relationship of the eastern and western portions of the site. The scope of work for the testing phase provided for mechanical removal of the upper $40 \mathrm{~cm}$ of recent alluvial fill prior to manual excavation. With the recovery of a Hare biface, faunal material, and several sherds of aboriginal ceramics at $20-40 \mathrm{~cm}$ bs, the use of heavy machinery would not be advised for data recovery investigations at this site.
Focusing upon the overall site structure, the following scenario is proposed for data recovery at 41MM341:

\section{1) Excavation of an approximately $100 \mathrm{~m}^{2}$ grid, encompassing the test units.}

This strategy would target excavation of the area contained within the $15 \mathrm{~m}$ separating the two portions of the site. With the dearth of cultural material recovered during the testing phase, the focus of the data recovery would be location of possible indicators of site structure and formation. Thus, the uppermost component, displaced by the use of heavy machinery during test excavations, would be further delineated, the areal extent of the southern portion of the midden would be determined, and the interrelation of the hearth and pit features and the shell midden would be investigated. Data recovery would thus be expected to multiply the results of the testing efforts approximately twelve-fold. With the terminal excavation depth of $1.6 \mathrm{~m}$, data recovery volume would equal $16,000 \mathrm{~m}^{3}$. 



\section{References Cited}

Ahr, S. W., and J. T. Abbott

1999 Archeological Survey of the Proposed State Highway 36 Bridge Replacement over the Little River and Road Widening Between Travis Street in Cameron to US 77, Milam County. CSJ: 0185-04-033 \& 034. Texas Department of Transportation, Austin.

Bousman, C. B.

1998 Paleoenvironmental Change in Central Texas: The Palynological Evidence. Plains Anthropologist 43(164):201-219.

Bryant, V. M., Jr.

1977 A 16,000 Year Pollen Record of Vegetation Change in Central Texas. Palynology 1:143-155.

Camper, H. A.

1991 Pollen Analysis of the Patschke Bog. Unpublished Master of Science thesis in Botany, Texas A\&M University, College Station.

Chipman, D. E.

1992 Spanish Texas 1519-1821. University of Texas Press. Austin.

Collins, M. B.

1995 Forty Years of Archeology in Central Texas. Bulletin of the Texas Archeological Society 66:361-400.

Dillehay, T. D.

1974 Late Quaternary Bison Population Changes on the Southern Plains. Plains Anthropologist 19(65):180196.

Ellis, G. L.

1997 Amino Acid Racemization Dating of Amblema plicata from the Corn Creek Middens. In Hot Rock Cooking on the Greater Edwards Plateau: Four Burned Rock Midden Sites in West Texas, by S. L. Black, L. W. Ellis, D. G. Creel, and G. T. Goode. Appendix G, Volume 2. Studies in Archaeology 22 and Archeology Studies Program Report 2. Texas Archeological Research Laboratory and Texas Department of Transportation, Austin.

Ellis, G. L., G. A. Goodfriend, J. T. Abbott, R. E. Hare, and D. W. Von Endt

1996 Assessment of Integrity and Geochronology of Archaeological Sites Using Amino Acid Racemization in Land Snails: Examples from Central Texas. Geoarchaeology 11:189-213.

Everitt, B. S.

1977 The Analysis of Contingency Tables. John Wiley and Sons, New York.

Fickel, W., Jr.

1993 Letter Report: Archeological Survey of Streambank Erosion along the Little River, Cameron, Milam County, Texas. Ft. Worth: COE-FWD. 
Gilmore, K. K.

1969 The San Xavier Missions: A Study in Historical Site Identification. Report Number 16. State Building Commission, Archeological Program.

Goodfriend, G. A.

1987 Evaluation of Amino-Acid Racemization/Epimerization Dating Using Radiocarbon-Dated Fossil Land Snail Shells. Geology 15:698-700.

2000 Appendix F: Rabdotus Shell A/I Ratios. In The Lino Site: A Stratified Late Archaic Campsite in a Terrace of the San Idelfonzo Creek, Webb County, Southern Texas, by J. M. Quigg. Technical Report No. 23756. TRC Mariah Associates, Austin, Texas.

Grim, R. E.

1968 Clay Mineralogy. McGraw-Hill, New York.

Holloway, R. G., L. M. Raab, and R. Stuckenrath

1987 Pollen Analysis of Late-Holocene Sediments from a Central Texas Bog. The Texas Journal of Science 39(1):71-79.

Johnson, L.

1995 Past Cultures and Climates at Jonas Terrace: 41ME29, Medina County, Texas. Report 40. Office of the State Archeologist, Austin.

Johnson, L., and G. T. Goode

1994 A New Try at Dating and Characterizing Holocene Climates, as well as Archeological Periods, on the Eastern Edwards Plateau. Bulletin of the Texas Archeological Society 65:1-51.

Kintigh, K. W.

1992 Tools for Quantitative Archaeology. Tempe, Arizona.

Mahoney, R. B., and R. G. Moore

1998 Data Recovery at 41 HR817 on Clear Creek, Harris County, Texas. Report of Investigation Number 227. Moore Archeological Consulting, Inc., Houston.

Perttula, T. K.

n.d. The Ceramic and Lithic Assemblage from a Late Prehistoric Site (41RT510) in the Post Oak Savanna, Robertson County, Texas. MS in preparation.

1999 Ceramic Evidence for Prehistoric Caddoan Trade and Exchange. Mini-NSF Grant Proposal on file, Research Reactor Center, University of Missouri, Columbia.

Prewitt, E. R.

1981 Cultural Chronology in Central Texas. Bulletin of the Texas Archeological Society 52:65-89.

1982 Archeological Investigations at the Loeve-Fox, Loeve and Tombstone Bluff Sites in the Granger Lake District of Central Texas. Archeological Investigations at the San Gabriel Reservoir Districts, CentraTexas, Volume 4. Institute of Applied Sciences, North Texas State University, Denton.

1985 From Circleville to Toyah: Comments on Central Texas Chronology. Bulletin of the Texas Archeological Society 54:201-238.

1995 Distributions of Typed Projectile Points in Texas. Bulletin of the Texas Archeological Society 66:83173. 
Potzger, J. E., and B. C. Tharp

1954 Pollen Study of Two Bogs in Texas. Ecology 35:462-466.

Prikryl, D. J.

2001 Fiction and Fact about the Titskanwatits, or Tonkawa, of East-Central Texas. Bulletin of the Texas Archeological Society 72 (in press).

Quigg, J. M.

1999 Archaeological Monitoring at Upland Sites 41ZP39 and 41ZP176 for TransTexas Gas Well Site USA \#3, Falcon Reservoir, Zapata County, Texas. Technical Report 23224. TRC Mariah and Associates, Austin, Texas.

Ramsey, C. B.

2000 OxCal Program Version 3.5. Radiocarbon Accelerator Unit, University of Oxford, Oxford, UK.

Rogers, R.

1999 Excavations at the Walleye Creek Site (41LE57), Lee County, Texas. Document Number 981670. Espey, Huston \& Associates, Inc., Austin.

Rogers, R., and S. M. Kotter

1995 Archaeological Investigations at the Chesser Site (41LE59), Lee County, Texas. Document Number 950209. Espey, Huston \& Associates, Inc., Austin.

Story, D., and H. J. Shafer

19651964 Excavations at Waco Reservoir, McLennan County, Texas: The Baylor and Britton Sites. Miscellaneous Papers No. 6. Texas Archeological Salvage Project, The University of Texas at Austin.

Stuvier, M., and P. J. Reimer

1993 Extended ${ }^{14} \mathrm{C}$ Database and Revised CALIB Radiocarbon Calibration Program. Radiocarbon 35:215230.

Suhm, D., and E. B. Jelks

1962 Handbook of Texas Archeology: Type Descriptions. Texas Archeological Society Special Publication Number 1 and Texas Memorial Museum Bulletin Number 4, Austin.

Texas State Department of Highways and Public Transportation (TSDHPT)

1990 Cultural Resources Survey Milam County F.M. 485: From Tyson Creek to the Brazos River. Letter Report. TSDHPT, Austin.

Turner, E. S., and T. R. Hester

1993 A Field Guide to Stone Artifacts of Texas Indians. Gulf Publishing Company, Houston, Texas.

Turpin, J., and S. M. Carpenter

1994 Continuing Cultural Resource Management at Calvert Mine: 1993 Prehistoric Site Testing, Robertson County. Technical Series No. 42. Texas Archeological Research Laboratory, The University of Texas at Austin. 
Turpin, S. A., L. C. Bement, and D. G. Robinson

1991 All American Pipeline Project: Final Status Report. Texas Archeological Research Laboratory, Austin.

Van Horn, D. M., J. R. Murray, and J.V. Linscheid

1993 A Method for Effectively Screening Some Clay Matrices. In Practical Archaeology, Field and Laboratory Techniques and Archaeological Logistics, edited by B. D. Dillon. Institute of Archaeology, University of California, Los Angeles.

Ward, G. K., and S. R. Wilson

1978 Procedures for Comparing and Combining Radiocarbon Age Determinations: A Critique. Archaeometry 20:19-31.

Wilson, S. R., and G. K. Ward

1981 Evaluation and Clustering of Radiocarbon Age Determinations: Procedures and Paradigms. Archaeometry 21:19-39. 


\section{Appendix A}

\section{Soil - Stratigraphic Descriptions}


BHT-24 (Block 1, 41MM341); elevation 85.7 to $86.1 \mathrm{~m}$; floodplain; calcareous throughout; A/C-Bk2 horizons from middle south wall, Ab2-Bk3 horizons from north wall on west end.

A/C 0-15 cm; (Unit 3); gray (10YR 3.5/1) clay; moderate fine and medium angular blocky; very hard; few clay clasts, $0.5 \mathrm{~cm}$; clear smooth.

A1 15-36 cm; gray (10YR 3.5/1) clay; moderate medium angular blocky; firm; common clay clasts, $0.5 \mathrm{~cm}$; gradual smooth.

A2 36-87 cm; dark gray (10YR 3/1) clay; few brown (10YR 5/3) pockets; moderate coarse angular blocky; firm; few clay clasts, $0.5 \mathrm{~cm}$; gradual smooth.

Bk1b1 87-113 cm; (Unit 2); dark grayish brown (10YR 4/2) clay; few brown (10YR 5/3) pockets; weak coarse prismatic; firm; $3 \%$ calcium carbonate filaments; gradual smooth.

Bk2 113-137 cm; dark grayish brown (10YR 4/2) clay; weak coarse prismatic; firm; 3\% calcium carbonate filaments, $1 \%$ carbonate nodules, $0.5 \mathrm{~cm}$; clear smooth.

Ab2 137-177 cm; (Unit 1); dark gray (10YR 3/1) clay; few dark grayish brown (10YR 3.5/2) pockets; few fine faint yellowish brown (10YR 3/4) soft iron masses; weak coarse subangular blocky; firm; $1 \%$ calcium carbonate filaments; $1 \%$ calcium carbonate nodules, $0.5 \mathrm{~cm}$; gradual smooth.

Bk1 177-219 cm; dark grayish brown (10YR 4/2) clay; common fine very dark grayish brown (10YR $3 / 2$ ) pockets; weak coarse angular blocky; firm; few faint slickensides; $2 \%$ calcium carbonate nodules, 0.5 to $1 \mathrm{~cm} ; 1 \%$ calcium carbonate filaments; gradual smooth.

Bk2 219-258 cm; dark grayish brown (10YR 4/2) clay; few very dark grayish brown (10YR 3/2) pockets; weak coarse prismatic; very firm; $3 \%$ calcium carbonate filaments; $2 \%$ calcium carbonate nodules, 0.5 to $1 \mathrm{~cm}$; gradual smooth.

Bk3 258-284 cm; light olive brown (2.5Y 5/3) clay; 20\% fine faint gray (10YR 5/1) iron depletions; few fine distinct yellowish brown (10YR 5/4) soft iron masses; weak coarse prismatic; very firm; $2 \%$ calcium carbonate filaments; $2 \%$ calcium carbonate nodules, 0.5 to $1 \mathrm{~cm}$.

BHT-15 (Block 2, 41MM341); elevation 86.1 to $86.2 \mathrm{~m}$; floodplain; calcareous throughout; A/C-Bk2 horizons from middle east wall, Akb2-Bk3 horizons from east wall below test unit.

A/C 0-24 cm; (Unit 3); dark gray (10YR 3.5/1) clay; moderate medium angular blocky and platy; very hard; clear smooth.

A $\quad 24-53 \mathrm{~cm}$; dark gray (10YR 3.5/1) clay; few brown (10YR 5/3) pockets; weak coarse angular blocky; firm; common clay clasts, $0.5 \mathrm{~cm}$; clear smooth.

Ab1 53-79 cm; (Unit 2); very dark gray (10YR 3/1) clay; few brown (10YR 5/3) pockets; moderate medium and coarse angular blocky; firm; few clay clasts, $0.5 \mathrm{~cm}$; gradual smooth.

Bk1 79-113 cm; dark grayish brown (10YR 3.5/2) clay; 10\% brown (10YR 5/3) pockets; weak coarse prismatic; hard; $2 \%$ calcium carbonate filaments; gradual smooth.

Bk2 113-140 cm; dark grayish brown (10YR 4/2) clay; weak medium and coarse prismatic; firm; 3\% calcium carbonate filaments; clear smooth

Akb2 140-159 cm; (Unit 1); dark gray (10YR 3/1) clay; 10\% dark grayish brown (10YR 4/2) pockets; weak coarse angular blocky; very firm; gradual smooth. 
Bk1 159-188 cm; dark gray (10YR 3.5/1) clay; 5\% fine distinct gray (10YR 5/1) iron depletions along ped faces; few fine distinct dark yellowish brown (10YR 3/4) soft iron masses; moderate coarse prismatic; very firm; $2 \%$ calcium carbonate filaments; $2 \%$ calcium carbonate nodules, 0.5 to $1 \mathrm{~cm}$; gradual smooth.

Bk2 188-223 cm; dark grayish brown (10YR 3.5/2) clay; 5\% fine distinct gray (10YR 5/1) iron depletions along ped faces; moderate coarse prismatic; very firm; $3 \%$ calcium carbonate nodules; $1 \%$ calcium carbonate filaments; gradual smooth.

Bk3 223-280 cm; light olive brown (2.5Y 5/3) clay; few fine distinct dark yellowish brown (10YR 4/4) soft iron masses; $5 \%$ fine distinct gray (10YR 5/1) iron depletions along ped faces; weak coarse prismatic; extremely firm; $3 \%$ calcium carbonate nodules; $1 \%$ calcium carbonate filaments.

BHT-5; elevation $\div 85.5 \mathrm{~m}$; slough; calcareous throughout; east wall.

A/C 0-18 cm; (Unit 3); light olive brown (2.5Y 5/3), grayish brown (2.5Y 5/2), and very dark gray ( 2.5 Y 3/1) clay; massive; extremely firm; few siliceous pebbles, 0.3 to $0.5 \mathrm{~cm}$; abrupt smooth.

A $\quad 18-47 \mathrm{~cm}$; dark gray (10YR 3.5/1) clay loam; weak coarse angular blocky; firm; common clay clasts, $0.5 \mathrm{~cm}$; few siliceous pebbles, 0.3 to $0.5 \mathrm{~cm}$; gradual smooth.

Bw 47-96 cm; dark gray (10YR 3.5/1) clay loam; weak coarse angular blocky; firm; two faint yellowish brown (10YR 5/4) beds, $1 \mathrm{~cm}$; common clay clasts, $0.5 \mathrm{~cm}$; clear smooth.

$\mathrm{Ab} \quad 96-120 \mathrm{~cm}$; (Unit 2); very dark gray (10YR 3/1) clay; few yellowish brown (10YR 5/4) pockets; weak coarse angular blocky; very hard; common clay clasts, $0.5 \mathrm{~cm}$; gradual smooth.

Bw 120-156 cm; dark gray (10YR 3.5/1) clay; few yellowish brown (10YR 5/4) pockets; weak coarse angular blocky; very hard; common clay clasts, $0.5 \mathrm{~cm}$; gradual smooth.

C 156-240 cm; bedded clays and loams; clays-very dark and dark gray (10YR 3/1, 4/1), many clay clasts, 3 to $10 \mathrm{~cm}$; loams-light brownish gray (10YR 6/2) and light gray (10YR 7/2) very fine sandy loam and silt loam, 0.2 to $0.5 \mathrm{~cm}$.

BHT-16; elevation 85.4 m; slough; calcareous throughout; east wall.

A/C1 0-9 cm; (Unit 3); very dark gray (10YR 3/1) clay; distinct bedding planes; hard; abrupt smooth.

A/C2 9-38 cm; dark gray (10YR 3.5/1) clay; massive; plastic; 5\% siliceous pebbles, 0.5 to $2 \mathrm{~cm}$; abrupt wavy.

Ab1 38-87 cm; dark grayish brown (10YR 3.5/2) clay; faint brown (10YR 5/3) bed in middle; weak coarse angular blocky; very firm; common clay clasts, $0.5 \mathrm{~cm}$; gradual smooth.

Bw 87-109 cm; dark grayish brown (10YR 4/2) clay; weak coarse angular blocky; very firm; common clay clasts, $0.5 \mathrm{~cm}$; gradual smooth.

Bss 109-131 cm; dark grayish brown (10YR 4/2) clay; moderate medium angular blocky; very firm; common distinct slickensides; abrupt smooth.

A1b1 131-165 cm; (Unit 2); dark grayish brown (2.5Y 4/2) clay; 30\% brown (10YR 5/3) pockets; light brownish gray (10YR 6/2) silt loam lamination at top and bottom, $3 \mathrm{~mm}$; faint light brownish gray (10YR 6/2) silt loam bed in middle, $2 \mathrm{~cm}$; weak coarse angular blocky; very firm; few distinct slickensides; clear smooth. 
A2 165-210 cm; dark gray (10YR 3.5/1) clay; few brown (10YR 5/3) pockets; weak coarse angular blocky; extremely firm; few distinct slickensides; $1 \%$ calcium carbonate nodules, $0.5 \mathrm{~cm}$; gradual smooth.

Bk 210-245 cm; grayish brown (2.5Y 4.5/2) clay; weak coarse angular blocky; extremely firm; $5 \%$ fine faint dark gray $(2.5 \mathrm{Y} 4 / 1)$ iron depletions along ped faces; few fine distinct dark yellowish brown (10YR 4/4) soft iron masses.

BHT-18; elevation $85.5 \mathrm{~m}$; slough; calcareous throughout; east wall.

A/C $\quad 0-17 \mathrm{~cm}$; (Unit 3); dark grayish brown (2.5Y 4/2) clay; very dark gray (2.5Y 3/1) bed in middle, 2 $\mathrm{cm}$; weak coarse angular blocky; very firm; clear smooth.

A $\quad 17-53 \mathrm{~cm}$; dark grayish brown (10YR 4/2) clay; moderate coarse angular blocky; firm; common clay clasts, $0.5 \mathrm{~cm}$; clear smooth.

Ab1 53-72 cm; dark grayish brown (10YR 3.5/2) clay; weak coarse angular blocky; firm; common clay clasts, $0.5 \mathrm{~cm}$; gradual smooth.

Bw $\quad 72-120 \mathrm{~cm}$; dark grayish brown (2.5Y 4/2) clay; 3\% brown (10YR 5/3) pockets; weak coarse prismatic; very firm; few faint slickensides; few clay clasts, $0.5 \mathrm{~cm}$; clear smooth.

C 120-143 cm; dark grayish brown (10YR 3.5/2) clay; 5\% brown (10YR 5/3) pockets; weak coarse prismatic; very hard; few clay clasts, $0.5 \mathrm{~cm}$; gradual smooth.

Ab2 143-180 cm; (Unit 2); very dark grayish brown (10YR 3/2) clay; 3\% dark grayish brown (10YR 4/ 2) pockets; weak coarse angular blocky; very hard; gradual smooth.

Bk 180-211 cm; dark grayish brown (2.5Y 4/2) and light olive brown (2.5Y 5/3) clay; few fine faint dark yellowish brown (10YR 4/4) soft iron masses; weak coarse prismatic; very hard; $1 \%$ calcium carbonate nodules, $0.5 \mathrm{~cm}$; abrupt smooth.

Bg 211-235 cm; very dark gray (10YR 3/1) clay; 15\% brown (10YR 4.5/3) and dark grayish brown (10YR 4/2) pockets; few fine faint gray (2.5Y 5/1) iron depletions; weak coarse angular blocky; extremely firm; many clay clasts, $0.5 \mathrm{~cm}$; gradual smooth.

BC $\quad 235-288 \mathrm{~cm}$; dark gray (10YR 4/1) clay; weak coarse angular blocky to massive; extremely firm.

BHT-7; elevation $85.5 \mathrm{~m}$; slough; calcareous throughout; east wall.

A1 0-33 cm; (Unit 3); dark gray (2.5Y 3.5/1) clay; weak medium and coarse subangular blocky; firm; few medium distinct dark yellowish brown (10YR 4/4) soft iron masses; $5 \%$ fine faint gray $(2.5 \mathrm{Y} 5 /$ 1) iron depletions along ped faces; clear smooth.

A2 33-51 cm; very dark gray (2.5Y 3/1) clay; moderate medium and coarse angular blocky; very firm; common medium distinct dark yellowish brown (10YR 4/4) soft iron masses; few faint gray (2.6Y 6/1) laminations; gradual smooth.

Bw 51-64 cm; dark gray (2.5Y 4/1) and light brownish gray (2.5Y 6/2) clay loam; weak coarse angular blocky; very hard; clear smooth.

Ab1 64-85 cm; very dark gray (10YR 3/1) clay; few light brownish gray (2.5Y 6/2) pockets; weak coarse angular blocky; hard; few siliceous pebbles, 0.2 to $0.5 \mathrm{~cm}$; gradual smooth.

$\mathrm{Bw} \quad 85-104 \mathrm{~cm}$; dark grayish brown (2.5Y 4/2) clay loam; $10 \%$ light brownish gray $(2.5 \mathrm{Y} 6 / 2)$ pockets; weak coarse angular blocky; hard; few siliceous pebbles, 0.2 to $0.5 \mathrm{~cm}$; gradual smooth. 
C 104-114 cm; dark gray (10YR 3.5/1) clay loam; $\%$ faint light brownish gray (2.5 6/2) laminations; hard; clear smooth.

Ab2 114-133 cm; ; (Unit 2); dark gray (10YR 3.5/1) clay; 10\% light brownish gray (2.5Y 6/2) pockets; weak coarse angular blocky; hard; few fine distinct dark brown (7.5YR 3/4) soft iron masses; gradual smooth.

C 133-141 cm; dark gray (10YR 4/1) clay; common medium distinct dark yellowish brown (10YR 3/ 4) soft iron masses; hard; clear smooth.

Ab3 141-166 cm; very dark gray (10YR 3/1) clay; weak coarse angular blocky; very firm; common medium distinct dark yellowish brown (10YR 4/4) soft iron masses; gradual smooth.

Bg 166-218 cm; dark gray (10YR 4/1) clay; common medium distinct dark yellowish brown (10YR 4/ 6) soft iron masses; $5 \%$ faint light brownish gray (2.5Y 6.2) laminations; weak coarse angular blocky; firm; gradual smooth.

$\mathrm{Cg} 1 \quad 218-247 \mathrm{~cm}$; laminated very dark gray and dark gray $(2.5 \mathrm{Y} 3 / 1,4 / 1)$ clay; common medium distinct dark yellowish brown (10YR 4/4) soft iron masses; firm; clear smooth.

$\mathrm{Cg} 2 \quad 247-280 \mathrm{~cm}$; dark gray (2.5Y 4/1) clay; massive; very firm; many medium distinct dark yellowish brown (10YR 4/4) soft iron masses.

BHT-8; elevation 85.7 to 85.9 m; floodplain; calcareous throughout; south wall.

A/C 0-22 cm; (Unit 3); massive gray (10YR 5/1) with faint yellowish brown (10YR 5/4) laminations; friable; abrupt wavy.

Ab1 22-39 cm; (Unit 2); very dark gray (10YR 3.5/1) clay; weak coarse angular blocky; very firm; gradual smooth.

Bw $\quad 39-75 \mathrm{~cm}$; dark gray (10YR 4/1) clay; weak coarse angular blocky; extremely firm; few medium faint brown (10YR 4/3) soft iron masses; clear smooth.

Ab2 75-88 cm; (Unit 1); very dark gray (2.5Y 3/1) clay; few light olive brown (2.5Y 5/3) pockets; weak coarse angular blocky; extremely firm; gradual smooth.

Bk1 88-119 cm; brown (10YR 4/3) clay; 5\% very dark gray (10YR 3/1) pockets; weak coarse prismatic; very hard; $2 \%$ calcium carbonate filaments; gradual smooth.

Bk2 119-143 cm; dark grayish brown (10YR 4/2) clay; 5\% very dark gray (10YR 3/1) pockets; weak coarse prismatic; very hard; $5 \%$ calcium carbonate filaments; gradual smooth.

Bk3 143-200 cm; gray (10YR 4/1) clay; weak medium prismatic; very hard; moderate medium distinct dark yellowish brown (10YR 4/4/) soft iron masses; 5\% calcium carbonate filaments; gradual smooth.

Bk4 200-281 cm; gray (10YR 4/1) clay; weak medium prismatic; very hard; moderate medium distinct dark yellowish brown (10YR 4/4) soft iron masses; $2 \%$ calcium carbonate filaments; gradual smooth.

Bk5 281-300 cm; light olive brown (2.5Y 5/4) clay; many medium distinct dark gray (2.5Y 4/1) pockets; weak coarse prismatic; very hard; $3 \%$ calcium carbonate filaments.

BHT-13; elevation 85.9 m; floodplain; calcareous throughout; east wall.

A/C 0-14 cm; (Unit 3); backhoe trench backfill, variegated colors; massive; gradual smooth. 
Ab1 14-29 cm; dark grayish brown (10YR 3.5/2) clay; weak medium angular blocky; firm; gradual smooth.

Bw1 29-62 cm; dark grayish brown (10YR 4/2) clay; weak medium and coarse angular blocky; firm; gradual smooth.

Bw2 62-117 cm; grayish brown (2.5Y 5/2) clay; weak medium and coarse angular blocky; firm; gradual smooth.

Ab2 117-161 cm; (Unit 2); dark grayish brown (2.5Y 4/2) clay; weak coarse prismatic to moderate medium angular blocky; firm; few faint slickensides; gradual smooth.

Bk1 161-191 cm; dark grayish brown (10YR 4/2) clay; moderate medium prismatic; very firm; 2\% calcium carbonate filaments; gradual smooth.

Bk2 191-230; grayish brown (10YR 4.5/2) clay; weak coarse prismatic; very firm; $2 \%$ calcium carbonate nodules, 0.5 to $1 \mathrm{~cm}$.

BHT-12; elevation 85.6 m; floodplain; calcareous throughout; east wall.

A/C 0-13 cm; (Unit 3); dark grayish brown (10YR 3.5/2) clay; weak medium subangular blocky; very firm; clear smooth.

Ab1 13-35 cm; very dark grayish brown (10YR 3/2) clay; weak medium subangular blocky; very firm; gradual smooth.

C 35-61 cm; grayish brown (10YR 4/2.5) clay; massive; firm; faint beds; clear smooth.

Ab2 61-95 cm; (Unit 2); very dark grayish brown (10YR 3/2) clay; weak coarse angular blocky; very hard; $5 \%$ light yellowish brown (10YR 5/4) pockets; gradual smooth.

Bk1 95-141 cm; grayish brown (10YR 4.5/2) clay; weak coarse angular blocky; very hard; 5\% light yellowish brown (10YR 5/4) pockets; $1 \%$ calcium carbonate filaments; $1 \%$ calcium carbonate filaments; gradual smooth.

Bk2 141-200 cm; gray (10YR 5/1) clay; weak coarse angular blocky; very hard; $1 \%$ calcium carbonate filaments; $1 \%$ calcium carbonate filaments; few faint slickensides; gradual smooth.

BHT-2; elevation 85.5-85.6 m; slough; calcareous throughout; south wall.

A1 0-19 cm; (Unit 3); very dark grayish brown (2.5Y 3/2) clay; strong medium subangular; firm; common siliceous pebbles, $0.5 \mathrm{~cm}$; gradual smooth.

A2 19-36 cm; dark grayish brown (2.5Y 3/2) clay; moderate coarse subangular; firm; few siliceous pebbles, $0.5 \mathrm{~cm}$; few clay clasts, $0.5 \mathrm{~cm}$; gradual smooth.

Bw1 36-75 cm; dark grayish brown (2.5Y 4/2) clay; weak coarse subangular blocky; firm; few siliceous pebbles, $0.5 \mathrm{~cm}$; faint light brownish yellow $(2.5 \mathrm{Y} 6 / 4)$ laminations in lower $5 \mathrm{~cm}$; abrupt smooth.

Bw2 75-92 cm; dark grayish brown (2.5Y 3.5/2) clay; weak medium angular blocky; very firm; 5\% light yellowish brown (2.5Y 6/3) pockets; clear smooth.

Bw/C 92-129 cm; dark grayish brown (2.5Y 4/2) clay loam; common distinct pale brown (10YR 6/3) laminations; many clay clasts, 0.5 to $1.5 \mathrm{~cm}$; abrupt smooth.

C1 129-143 cm; faintly laminated pale brown (10YR 6/3) and very dark grayish brown (10YR 3/2) silty clay loam; hard; abrupt smooth. 
C2 143-153 cm; few faint pale brown (10YR 6/3) and very dark grayish brown (10YR 3/2) laminated clays; very hard; many clay clasts, 0.5 to $2 \mathrm{~cm}$; few fine distinct brown (7.5YR 4/4) soft iron masses; abrupt smooth.

C3 153-202 cm; laminated pale brown (10YR 6/3) and dark grayish brown (10YR 4/2) silt loam; hard; $5 \%$ very dark grayish brown (10YR 3/2) pockets; abrupt smooth.

C4 202-217 cm; few distinct pale brown (10YR 6/3) and very dark grayish brown (10YR 3/2) laminated silt loams; slightly hard.

BHT-11; elevation $85.3 \mathrm{~m}$; north slough; calcareous throughout; north wall.

fill $\quad 0-33 \mathrm{~cm}$; (Unit 3); very dark gray (10YR 3.5/1) clay; weak coarse angular blocky; very firm; common siliceous pebbles, 0.5 to $2 \mathrm{~cm}$; abrupt wavy.

fill 33-72 cm; very dark gray and black $(2.5 \mathrm{Y} 3 / 1,2 / 1)$ and brownish yellow (10YR 6/6) clay; massive; firm; many siliceous pebbles, 0.5 to $2 \mathrm{~cm} ; 2 \%$ detrital calcium carbonate nodules, $1 \mathrm{~cm}$; abrupt wavy.

Bw $\quad 72-99 \mathrm{~cm}$; dark gray (2.5Y 3.5/1) clay; common fine distinct brown (7.5YR 4/4) soft iron masses; weak coarse angular blocky; firm; few clay clasts, $0.5 \mathrm{~cm}$; clear smooth.

Assgb1 99-132 cm; (Unit 2); very dark gray (2.5Y 3/1) clay; few fine distinct brown (7.5YR 4/4) soft iron masses; weak coarse angular blocky; very firm; common distinct slickensides; gradual smooth.

Bg1 132-161 cm; gray (2.5Y 5/1) clay; common fine distinct dark yellowish brown (10YR 4/4); weak coarse angular blocky; firm; clear smooth.

Bg2 161-186 cm; dark gray (2.5Y 4/1) clay; weak coarse angular blocky; very firm; common fine distinct yellowish brown (10YR 5/4) soft iron masses; gradual smooth.

Bg3 186-208 cm; gray (2.5Y 5/1) clay; moderate medium distinct brown (7.5YR 5/4) soft iron masses; weak coarse angular blocky; very firm; $1 \%$ calcium carbonate nodules; gradual smooth.

Bg4 208-230 cm; gray (2.5Y 5/1) clay; few fine distinct yellowish brown (10YR 4/4) soft iron masses; weak coarse angular blocky; very firm.

BHT-26 (Block 1, 41MM340); elevation 85.5 to 85.9 m; floodplain; calcareous throughout; south wall.

A/C 0-18 cm; (Unit 3); dark gray (10YR 3/1.5) clay; moderate coarse platy; very hard; common siliceous pebbles, $0.5 \mathrm{~cm}$; clear smooth.

Ab1 18-43 cm; (Unit 2); dark gray (10YR 3.5/1) clay; weak coarse angular blocky; very hard; gradual smooth.

Bw 43-71 cm; dark grayish brown (2.5Y 3.5/2) clay; weak coarse angular blocky; firm; few siliceous pebbles, $0.5 \mathrm{~cm}$; clear smooth.

Ab2 71-94 cm; (Unit 1); dark gray (2.5Y 3.5/1) clay; weak coarse angular blocky; very firm; 3\% light olive brown $(2.5 \mathrm{Y} 5 / 3)$ pockets; $1 \%$ calcium carbonate filaments; gradual smooth.

Bk1 94-115 cm; grayish brown (2.5Y 3.5/2) clay; 3\% light olive brown (2.5Y 5/3) pockets and 1\% very dark gray $(2.5 \mathrm{Y} 3 / 1)$ pockets; weak coarse angular blocky; firm; $2 \%$ calcium carbonate filaments; gradual smooth. 
Bk2 115-140 cm; gray (2.5Y 4/1) clay; weak coarse angular blocky; very firm; $1 \%$ very dark gray (2.5Y $3 / 1$ ) pockets; moderate medium distinct brown (10YR 4/3) soft iron masses; $4 \%$ calcium carbonate filaments; gradual smooth.

Bk3 140-177 cm; gray (2.5Y 4/1) clay; common medium distinct dark yellowish brown (10YR 4/4) soft iron masses; weak coarse angular blocky; firm; $3 \%$ calcium carbonate nodules, 0.5 to $1 \mathrm{~cm}$.

BHT-B (Block 2, 41MM340); elevation 85.9 m; floodplain; calcareous throughout; late Holocene over early Holocene alluvium; east wall.

A1 0-8 cm; (Unit 3); dark gray (2.5Y 3.5/1) clay; weak coarse angular blocky; very firm; clear smooth.

A2 8-31 cm; very dark gray (2.5Y 3.5/1) clay; weak coarse angular blocky; very firm; clear wavy.

Bw1b1 31-60 cm; (Unit 2); very dark gray (10YR 3/1) clay; weak coarse angular blocky; very firm; clear wavy.

Bw2 60-74 cm; very dark gray (10YR 3/1) clay; weak coarse angular blocky; very firm; clear smooth.

Akb2 74-90 cm; (Unit 1); black (2.5Y 2.5/1) clay; moderate medium prismatic to moderate medium angular blocky; very hard; $2 \%$ dark grayish brown pockets; $2 \%$ calcium carbonate filaments; gradual smooth.

Bk1 90-116 cm; very dark gray (10YR 3/1) clay; moderate medium prismatic to moderate medium angular blocky; very hard; 8\% calcium carbonate filaments; gradual smooth.

Bk2 116-139 cm; dark gray (2.5Y 3.5/1) clay; few black (2.5Y 2.5/1) pockets; 30\% brown (10YR 5/3) pockets; moderate medium prismatic to moderate medium angular blocky; very hard; $10 \%$ calcium carbonate filaments; gradual smooth.

Bk3 139-157 cm; very dark gray (2.5Y 3/1) clay; 30\% brown (10YR 5/3) pockets; moderate medium prismatic to moderate medium angular blocky; very hard; $10 \%$ calcium carbonate filaments; gradual smooth.

Bk4 157-180 cm; yellowish brown (10YR 5/4) clay; few fine distinct dark yellowish brown (10YR 4/6) soft iron masses; common medium distinct dark gray (2.5Y 4/1) iron depletions along ped faces; weak coarse prismatic; very hard; $10 \%$ calcium carbonate filaments.

BHT-A (Block 3, 41MM340); elevation 85.4 to 85.7 m; floodplain; calcareous throughout; north wall; (missing upper $30 \mathrm{~cm}$ ).

Bw 0-31 cm; (Unit 3); dark gray (10YR 3/1.5) clay; weak coarse angular blocky; very firm; clear smooth.

Ab1 31-58 cm; (Unit 1); very dark gray (10YR 3/1) clay; moderate medium prismatic to moderate medium angular blocky; very hard; $1 \%$ dark grayish brown (10YR 4/2) pockets; $1 \%$ calcium carbonate filaments; gradual smooth.

Akb2 58-79 cm; very dark gray 10YR 3/1) clay; 2\% dark grayish brown (10YR 4/2) pockets; weak coarse prismatic; very hard; $5 \%$ calcium carbonate filaments; gradual smooth.

Bk2 79-117 cm; dark gray (10YR 4/1) clay; 5\% dark yellowish brown (10YR 4/4) pockets; weak coarse prismatic; very hard; $5 \%$ calcium carbonate filaments; gradual smooth. 
Bk3 117-134 cm; dark gray (10YR 4/1) clay; weak coarse prismatic; very hard; moderate medium distinct yellowish brown (10YR 5/4) soft iron masses; 5\% calcium carbonate filaments.

CB-6; modern levee; calcareous throughout.

C $\quad$ 0-2 cm; (Unit 3); pale brown (10YR 6/3) fine sandy loam; single grain; abrupt wavy.

A 2-29 cm; very dark gray (10YR 3/1) clay; moderate fine and medium subangular blocky; very hard; clear smooth.

Bw1 29-49 cm; dark gray (10YR 3.5/1) clay; moderate medium and coarse subangular blocky; very hard; faint bed in lower part, $2 \mathrm{~cm}$; clear smooth.

Bw2 49-71 cm; dark gray (10YR 3.5/1) clay; 30\% brown (10YR 5/3) pockets; moderate medium and coarse subangular blocky; hard; few faint laminations; brown clay bed at base, $2 \mathrm{~cm}$; clear smooth.

Bw3 71-87 cm; dark gray (10YR 3.5/1) and brown (10YR 5/3) laminated clay loam and loam; weak coarse angular blocky; hard; common faint laminations; abrupt smooth.

C1 87-123 cm; brown (10YR 5/3) loam; 30\% dark gray (10YR 4/1) pockets; massive; hard; common faint laminations; abrupt smooth.

C2 123-140 cm; dark gray (10YR 4/1) clay loam; weak coarse prismatic; very hard; $30 \%$ brown (10YR $5 / 3$ ) pockets; common fine distinct strong brown (7.5YR 4/6) iron pore linings; clear smooth.

C3 140-159 cm; brown (10YR 5/3) loam; 20\% dark gray (10YR 4/1) pockets; massive; hard; few faint laminations; $2 \mathrm{~cm}$ clay bed at base with common fine distinct strong brown (7.5YR 4/6) iron pore linings; abrupt smooth.

C4 159-194 cm; dark gray (10YR 4/1.5) clay loam; 10\% brown (10YR 5/3) pockets; weak coarse prismatic; very hard; common fine distinct strong brown (7.5YR 4/6) iron pore linings; clear smooth.

C5 194-220+ cm; pale brown (10YR 6/3) silt loam; 20\% dark gray (10YR 4/1) pockets; few distinct beds and laminations of clay and silt loam; massive; hard; common fine distinct strong brown (7.5YR 4/6) iron pore linings. 

Appendix B

\section{Radiocarbon Results}




\section{BETA ANALYTIC INC.}

\author{
DR. M.A. TAMERS and MR. D.G. HOOD
}

UNIVERSITY BRANCH

4985 S.W. 74 COURT

MIAMI, FLORIDA, USA 33155

PH: 305/667-5167 FAX: 305/663-0964

E-MAIL: beta@radiocarbon.com

\section{REPORT OF RADIOCARBON DATING ANALYSES}

Mr. Richard B. Mahoney

University of Texas at San Antonio
Report Date: May 1, 2000

Material Received: March 20, 2000

\begin{tabular}{llcc}
\hline Sample Data & $\begin{array}{c}\text { Measured } \\
\text { Radiocarbon Age }\end{array}$ & $\begin{array}{c}{ }^{13} \mathrm{C} /{ }^{12} \mathrm{C} \\
\text { Ratio }\end{array}$ & $\begin{array}{c}\text { Conventional } \\
\text { Radiocarbon Age (*) }\end{array}$ \\
\hline Beta-141825 & $2810+/-50 \mathrm{BP}$ & $-27.2 \% / 00$ & $2770+/-50 \mathrm{BP}$
\end{tabular}

SAMPLE \#: 41MM340-128

ANALYSIS: AMS-Standard delivery

MATERIAL/PRETREATMENT:(charred material): acid/alkali/acid

Beta-141826

$$
2900+/-40 \mathrm{BP}
$$

$-26.3 \%$

$2880+1-40 \mathrm{BP}$

SAMPLE \#: 41MM340-149

ANALYSIS: AMS-Standard delivery

MATERIAL/PRETREATMENT:(charred material): acid/alkali/acid

Beta-141827

$2380+/-50 \mathrm{BP}$

$-25.3 \mathrm{o} / \mathrm{oo}$

$2380+/-50 \mathrm{BP}$

SAMPLE \#: 41MM340-084

ANALYSIS: AMS-Standard delivery

MATERIAL/PRETREATMENT:(charred material): acid/alkali/acid

Beta-141828

SAMPLE \#: 41MM340-108

ANALYSIS: AMS-Standard delivery

MATERIAL/PRETREATMENT:(charred material): acid/alkali/acid

Beta-141829

$2600+/-50 \mathrm{BP}$

$-24.7 \%$

$2600+/-50 \mathrm{BP}$

SAMPLE \#: 41MM340-159

ANALYSIS: AMS-Standard delivery

MATERIAL/PRETREATMENT:(charred material): acid/alkali/acid

Dates are reported as RCYBP (radiocarbon years before present, "present" = 1950A.D.). By International convention, the modern reference standard was $95 \%$ of the $\mathrm{C} 14$ content of the National Bureau of Standards' Oxalic Acid \& calculated using the Libby C14 half life (5568 years). Quoted errors represent 1 standard deviation statistics ( $68 \%$ probability) $\&$ are based on combined measurements of the sample, background, and modern reference standards.
Measured $\mathrm{C} 13 / \mathrm{C} 12$ ratios were calculated relative to the PDB-1 international standard and the RCYBP ages were normalized to -25 per mil. If the ratio and age are accompanied by an $\left(^{*}\right)$, then the $\mathrm{C} 13 / \mathrm{C} 12$ value was estimated, based on values typical of the material type. The quoted results are NOT calibrated to calendar years. Calibration to calendar years should be calculated using the Conventional C14 age. 


\section{REPORT OF RADIOCARBON DATING ANALYSES}

Mr. Richard B. Mahoney
Page 2 of 3

\begin{tabular}{rlcc}
\hline Sample Data & $\begin{array}{c}\text { Measured } \\
\text { Radiocarbon Age }\end{array}$ & $\begin{array}{c}{ }^{13} \mathrm{C} /{ }^{12} \mathrm{C} \\
\text { Ratio }\end{array}$ & $\begin{array}{c}\text { Conventional } \\
\text { Radiocarbon Age (*) }\end{array}$ \\
\hline Beta-141830 & $2440+/-40 \mathrm{BP}$ & $-22.7 \mathrm{o} / \mathrm{oo}$ & $2480+/-40 \mathrm{BP}$
\end{tabular}

SAMPLE \#: 41MM340-168

ANAL YSIS: AMS-Standard delivery

MATERIAL/PRETREATMENT:(charred material): acid/alkali/acid

Beta-1 41832

$2780+1-30 \mathrm{BP}$

$-26.10 / 00$

$2760+/-30 \mathrm{BP}$

SAMPLE \#: 41MM340-270

ANALYSIS: AMS-Standard delivery

MATERIAL/PRETREATMENT:(charred material): acid/alkali/acid

Beta-141833

$3090+/-40$ BP

$-26.7 \mathrm{o} / 00$

$3070+1-40 \mathrm{BP}$

SAMPLE \#: 41MM340-301

ANALYSIS: AMS-Standard delivery

MATERIAL/PRETREATMENT:(charred material): acid/alkali/acid

Beta-141834

$$
2420+/-40 \mathrm{BP}
$$

$-24.2 \mathrm{o} / \mathrm{oo}$

$2440+/-40 \mathrm{BP}$

SAMPLE \#: 41MM340-083

ANALYSIS: AMS-Standard delivery

MATERIAL/PRETREATMENT:(charred material): acid/alkali/acid

\section{Beta-141835}

$$
2440+/-40 \mathrm{BP}
$$

-25.8 o/oo

$2420+/-40 \mathrm{BP}$

SAMPLE \#: 41MM340-101

ANALYSIS: AMS-Standard delivery

MATERIAL/PRETREATMENT:(charred material): acid/alkali/acid

Dates are reported as RCYBP (radiocarbon years before present, "present" = 1950A.D.). By International convention, the modern reference standard was $95 \%$ of the $\mathrm{C} 14$ content of the National Bureau of Standards' Oxalic Acid \& calculated using the Libby C14 half life ( 5568 years). Quoted errors represent 1 standard deviation statistics ( $68 \%$ probability) \& are based on combined measurements of the sample, background, and modern reference standards.
Measured $\mathrm{C} 13 / \mathrm{C} 12$ ratios were calculated relative to the PDB-1 international standard and the RCYBP ages were normalized to -25 per mil. If the ratio and age are accompanied by an $\left({ }^{*}\right)$, then the

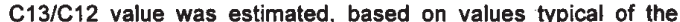
material type. The quoted results are NOT calibrated to calendar years. Calibration to calendar years should be calculated using the Conventional C14 age. 


\section{REPORT OF RADIOCARBON DATING ANALYSES}

Mr. Richard B. Mahoney

Page 3 of 3

\begin{tabular}{llcc}
\hline Sample Data & $\begin{array}{c}\text { Measured } \\
\text { Radiocarbon Age }\end{array}$ & $\begin{array}{c}{ }^{13} \mathrm{C} /{ }^{12} \mathrm{C} \\
\text { Ratio }\end{array}$ & $\begin{array}{c}\text { Conventional } \\
\text { Radiocarbon Age (*) }\end{array}$ \\
\hline Beta-141838 & $2800+/-40 \mathrm{BP}$ & $-25.2 \% / 00$ & $2800+/-40 \mathrm{BP}$
\end{tabular}

SAMPLE \#: 41MM340-175

ANALYSIS: AMS-Standard delivery

MATERIAL/PRETREATMENT:(charred material); acid/alkali/acid

Beta-1 $41840 \quad 3040+/-40 \mathrm{BP} \quad-24.3 \% / 00 \quad 3050+/-40 \mathrm{BP}$

SAMPLE \#: 41MM340-242

ANALYSIS: AMS-Standard delivery

MATERIAL/PRETREATMENT:(charred material): acid/alkali/acid

Beta-141841

$$
520+/-40 \mathrm{BP}
$$

$-26.4 \%$

$500+/-40 \mathrm{BP}$

SAMPLE \#: 41MM340-032

ANAL YSIS: AMS-Standard delivery

MATERIAL/PRETREATMENT:(charred material): acid/alkali/acid

\section{Beta-141842}

$1280+/-40 \mathrm{BP}$

$-25.7 \mathrm{o} / \mathrm{oo}$

$1270+/-40 \mathrm{BP}$

SAMPLE \#: 41MM341-069

ANALYSIS: AMS-Standard delivery

MATERIAL/PRETREATMENT:(charred material): acid/alkali/acid

\section{Beta-141843}

$940+/-40 \mathrm{BP}$

$-24.9 \%$

$940+/-40 \mathrm{BP}$

SAMPLE \#: 41MM341-074

ANALYSIS: AMS-Standard delivery

MATERIAL/PRETREATMENT:(charred material): acid/alkali/acid

NOTE: It is important to read the calendar calibration information and to use the calendar calibrated results (reported separately) when interpreting these results in $A D / B C$ terms. NOTE: Four samples from this set were cancelled (as instructed).

Dates are reported as RCYBP (radiocarbon years before present, "present" = 1950A.D.). By International convention, the modern reference standard was $95 \%$ of the C14 content of the National Bureau of Standards' Oxalic Acid \& calculated using the Libby C14 half life (5568 years). Quoted errors represent 1 standard deviation statistics ( $68 \%$ probability) $\&$ are based on combined measurements of the sample, background, and modern reference standards.
Measured $\mathrm{C} 13 / \mathrm{C} 12$ ratios were calculated relative to the PDB-1 international standard and the RCYBP ages were normalized to -25 per mil. If the ratio and age are accompanied by an $\left({ }^{*}\right)$, then the $\mathrm{C}_{13 / \mathrm{C} 12}$ value was estimated, based on values typical of the material type. The quoted results are NOT calibrated to calendar years. Calibration to calendar years should be calculated using the Conventional $\mathrm{C} 14$ age. 


\title{
Appendix C
}

\section{Vertebrate Faunal Remains}

\author{
Barbara A. Meissner
}




\title{
Appendix C: Vertebrate Faunal Remains
}

\author{
Barbara A. Meissner
}

This report is intended to provide an assessment of the identifiable vertebrate fauna recovered from 41MM340 and 41MM341 during the project. Only the most readily identifiable bone was closely examined.

In general, the bone is in moderate to good condition. There is little evidence of extensive atmospheric or chemical weathering. Most of the bone is in very small pieces, but the general impression is that much of this breakage was done while the bone was fresh. This will be assessed in the final report. It appears, however, that the small number of bone recovered is not due to poor preservation. It seems likely that there were very few bones left in these sites, and that most of this bone was very heavily processed.

Seven genera of mammals were identified (see Table C-1). Deer, cottontail and jackrabbit were the most common. With two exceptions, all identified mammals are wild animals commonly found in the area today. One possible exception is Canis, which could be dog, coyote, or wolf. All of the Canis bone was about the size of a coyote, but could be large dog or small wolf.

The other exception was a single molar belonging to either a goat (Capra) or a sheep (Ovis). Although there are wild members of these genera in Texas, they are all adapted to mountainous environments and are only found in far West Texas. This tooth is probably from a domestic animal. Its location in Level 6 (50-60 cm below datum) presents a small problem. The earliest domestic sheep and goat in the area would have been in association with Mission San Xavier. It seems most likely that the goat/sheep tooth was from a much more recent animal. It could have fallen into a deep crack or been tracked into the unit in mud on someone's boot.

Bird bone was not uncommon in this collection, but most of it was highly fragmented, and none could be identified. Most of it appeared to be of duck size or larger. One bird bone bead, made on a long bone of a large bird (at least goose-sized, and possibly as large as a hawk) was identified.

Fragments of turtle carapace, many of which were burned, were common. Twenty-nine fragments were recovered at 41MM340, of which 16 were from a single Pseudomys individual and the rest were unidentifiable. Sixteen carapace fragments were identified at 41MM341. These included Pseudomys, Terrepene, and Trionyx genera, as well as a number of unidentified fragments.

The only fish identified was catfish (Ictalurus sp.). Most of this was the bones of a single medium-sized head, excavated in Block 1 of $41 \mathrm{MM} 340$, between 10 and $20 \mathrm{~cm}$ below datum. A few fragments of unidentified fish were also recovered, but these were rare. All were in 41MM340.

In conclusion, very little bone was recovered during this project. The condition of the bone that was found suggests that poor preservation is not the reason for the small numbers of bone. Much of the bone is in very small pieces and was probably heavily processed. The majority of the unidentified bone appears to be from animals of the deer/antelope size category, however at least two unidentified bones could have come from a bison-sized animal, based on cortical thickness. Most of the bone is from wild mammals, from genera still found in the area today, however, there are numerous bird bones and turtle shell fragments as well. 
Table C-1. Taxa identified from 41MM340 and 41MM341

\begin{tabular}{|c|c|c|c|c|}
\hline & Genus & Common Name & $41 \mathrm{MM340}$ & $41 \mathrm{MM341}$ \\
\hline \multirow[t]{7}{*}{ Mammals } & Canis & $\begin{array}{l}\text { Dog, Coyote, } \\
\text { Wolf }\end{array}$ & $\mathrm{X}$ & \\
\hline & Capra/Ovis & Goat or sheep & $\mathrm{X}$ & \\
\hline & Didelphis & Opossum & & $\mathrm{X}$ \\
\hline & Lepus & Jackrabbit & $\mathrm{X}$ & $\mathrm{X}$ \\
\hline & Odocoileus & Deer & & $\mathrm{X}$ \\
\hline & Procyon & Raccoon & $\mathrm{X}$ & \\
\hline & Sylvilagus & Cottontail & $\mathrm{X}$ & $\mathrm{X}$ \\
\hline \multirow[t]{3}{*}{ Reptiles } & Pseudomys & Pond Slider & $\mathrm{X}$ & $\mathrm{X}$ \\
\hline & Terrepene & Box Turtle & & $\mathrm{X}$ \\
\hline & Trionyx & $\begin{array}{l}\text { Soft-shelled } \\
\text { Turtle } \\
\end{array}$ & & $X$ \\
\hline Fish & Ictalurus & Catfish & $\mathrm{X}$ & \\
\hline
\end{tabular}





\section{Appendix D}

\section{Freshwater Mussel Shell}

Robert G. Howells 


\title{
Appendix D: Freshwater Mussel Shell
}

\author{
Robert G. Howells
}

\section{Introduction}

Freshwater mussels (Family Unionidae) have been used by Native Americans for food, tools, and decoration (Howells et al. 1996; Neck 1982) and are frequently associated with archeological sites. Following is a preliminary analysis of unionid shell remains obtained by the Center for Archaeological Research (CAR), University of Texas at San Antonio, from sites 41MM340 and 41MM341 near Little River (a Brazos River tributary), Milam County, Texas, in early 2000.

\section{Materials and Methods}

Specimens were obtained by CAR during archeological excavations at these two adjacent sites. Four lots of selected shells (49-50/lot) were selected for preliminary analysis. Specimens were identified using Howells et al. (1996) and by comparison to shells of species collected by the author in or near the Central Brazos River Drainage. Taxonomic terminology follows Howells et al. (1996). Additionally, annual statewide field-survey reports produced by Texas Parks and Wildlife Department (Howells 1995, 1996, 1997) were reviewed for comparative mussel assemblage composition by species and number. However, comparative data were selected only from river and stream sites with the exclusion of reservoir collections (no lakes or reservoirs were present in this area in prehistoric times).

\section{Results and Discussion}

A total of seven species of freshwater mussels were found among the 198 shells and valves examined (Table D1). These included threeridge (Amblema plicata), smooth pimpleback (Quadrula houstonensis), southern mapleleaf (Quadrula apiculata), Tampico pearlymussel (Cyrtonaias tampicoensis), bleufer (Potamilus purpuratus), false spike (Quincuncina mitchelli), and pistolgrip (Tritogonia verrucosa). Among these, threeridge and smooth pimpleback were far more abundant than other taxa. All of the identified species are (or were) typical of Brazos River unionid fauna (Howells et al. 1996; Strecker 1931).

Shells and valves examined were generally in very good condition. Some displayed signs of erosion since the time of the animal's death, but most were well preserved. Most had small to large portions of their disks absent, but with no clear evidence of human manipulation, including heating. Most specimens were smaller adults, but with a few juveniles or much larger adults occasionally represented.

Species composition varied between depth and site. Threeridge species decreased in abundance from 84 percent of the total at $43-53 \mathrm{~cm}$ below the surface (cm bs) at site $41 \mathrm{MM} 340$ to 66 percent at $94-104 \mathrm{~cm}$ bs and 44.9 percent at $124-134 \mathrm{~cm}$ bs, and was only 43.7 percent of the total collection from site 41MM341. Conversely, smooth pimpleback increased from 12 percent at $43-53 \mathrm{~cm}$ bs to 38.8 percent of the total at $124-134 \mathrm{~cm}$ bs at site 41MM340, and was 59.2 percent of the total collection from site 41MM341. Southern mapleleaf was present in all four lots, but only included 1-6 specimens/lot. Other taxa were even less frequent. 
Table D-1. Identification of selected freshwater mussel shell remains recovered from archeological sites 41MM340 and 41MM341

\begin{tabular}{|c|c|c|c|c|c|c|c|c|c|c|c|c|}
\hline Sample \# & Site & Block & Unit & $\begin{array}{c}\text { Elevation } \\
(\mathrm{cmbs})\end{array}$ & Lot\# & Zone & Common Name & Scientific Name & Shells & Valves & Total & \begin{tabular}{|c|} 
Percent of \\
Total
\end{tabular} \\
\hline \multirow[t]{4}{*}{1} & 41MM340 & 2 & $\mathrm{C}$ & $43-53$ & 78 & 2 & Threeridge & Amblema plicata & 1 & 41 & 42 & 84 \\
\hline & & & & & & & Smooth pimpleback & Quadrula houstonensis & 1 & 5 & 6 & 12 \\
\hline & & & & & & & Southern mapleleaf & Quadrula apiculata & 0 & 1 & 1 & 2 \\
\hline & & & & & & & Tampico pearlymussel & Cyrtonaias tampicoensis & 0 & 1 & 1 & 2 \\
\hline \multirow[t]{4}{*}{2} & 41MM340 & 3 & B & $94-104$ & 181 & 6 & Threeridge & Amblema plicata & 0 & 33 & 33 & 66 \\
\hline & & & & & & & Smooth pimpleback & Quadrula houstonensis & 0 & 15 & 15 & 30 \\
\hline & & & & & & & Southern mapleleaf & Quadrula apiculata & 0 & 1 & 1 & 2 \\
\hline & & & & & & & Bleufer & Potamilus purpuratus & 0 & 1 & 1 & 2 \\
\hline \multirow[t]{5}{*}{3} & 41MM340 & 3 & $\mathrm{~B}$ & $124-134$ & 235 & 8 & Threeridge & Amblema plicata & 0 & 22 & 22 & 44.9 \\
\hline & & & & & & & Smooth pimpleback & Quadrula houstonensis & 0 & 19 & 19 & 38.8 \\
\hline & & & & & & & Southern mapleleaf & Quadrula apiculata & 0 & 6 & 6 & 12.4 \\
\hline & & & & & & & False spike & Quincuncina mitchelli & 0 & 1 & 1 & 2 \\
\hline & & & & & & & Pis tolgrip & Tritogonia verrucosa & 0 & 1 & 1 & 2 \\
\hline \multirow[t]{4}{*}{4} & $41 \mathrm{MM} 341$ & 1 & B & $56-60$ & 33 & 2 & Threeridge & Amblema plicata & 0 & 17 & 17 & 34.7 \\
\hline & & & & & & & Smooth pimpleback & Quadrula houstonensis & 0 & 29 & 29 & 59.2 \\
\hline & & & & & & & Southern mapleleaf & Quadrula apiculata & 0 & 2 & 2 & 4.1 \\
\hline & & & & & & & Tampico pearlymussel & Cyrtonaias tampicoensis & 0 & 1 & 1 & 2 \\
\hline
\end{tabular}

Combined species assemblages from a number of locations in the Central Brazos River Drainage (Table D-2) indicate that threeridge is still the most abundant unionid taxon, but is reduced from percentages found at these archeological sites with percent composition falling from 34-84 percent historically to a mean of 27 percent in recent collections. Smooth pimpleback also fell from 12-59 percent in archeological samples to less than 10 percent in recent surveys. Conversely, southern mapleleaf increased in relative abundance from 2-4 percent to nearly 25 percent.

Freshwater mussels are sensitive barometers of environmental quality and are subsequently the most-rapidly declining faunal group in North America (Howells et al. 1996; Neves 1993; Williams et al. 1993). Freshwater mussel populations in Central Texas in particular have experienced dramatic changes in distribution, abundance, and composition since the late 1970s (Howells et al. 1997). Endemic smooth pimpleback has been eliminated from many parts of its range in Central Texas in recent years (Howells et al. 1997). Data from these archeological samples suggest its decline may have started long before human modification of aquatic ecosystems was initiated. This apparent early decline might be associated with a general trend toward a more arid environment in the region. False spike, another endemic, has apparently not been found alive since major flooding and associated scouring and habitat modification in 1978. The single specimen from the archeological samples, paucity of historical data, and complete absence of living or recently-dead specimens in current studies confounds useful conclusions about it. Pistolgrip ranges as far west as the Guadalupe River and the upper Brazos Drainage, but has declined in most areas west of the Neches River; often, for reasons that are not clearly apparent.

The increase in relative abundance of southern mapleleaf between the archeological collections and the present is particularly interesting. Archeological specimens must have been collected from riverine environments, because there were no lakes or reservoirs present in the area at the time of initial harvest and the species is not especially tolerant of ponds. Southern mapleleaf adapts well to many reservoirs despite having evolved in a flowing water habitat, and it can be disproportionately abundant in some reservoirs. The increase in apparent abundance seen here may reflect some other environmental shift. Again, as the region has become more arid and 


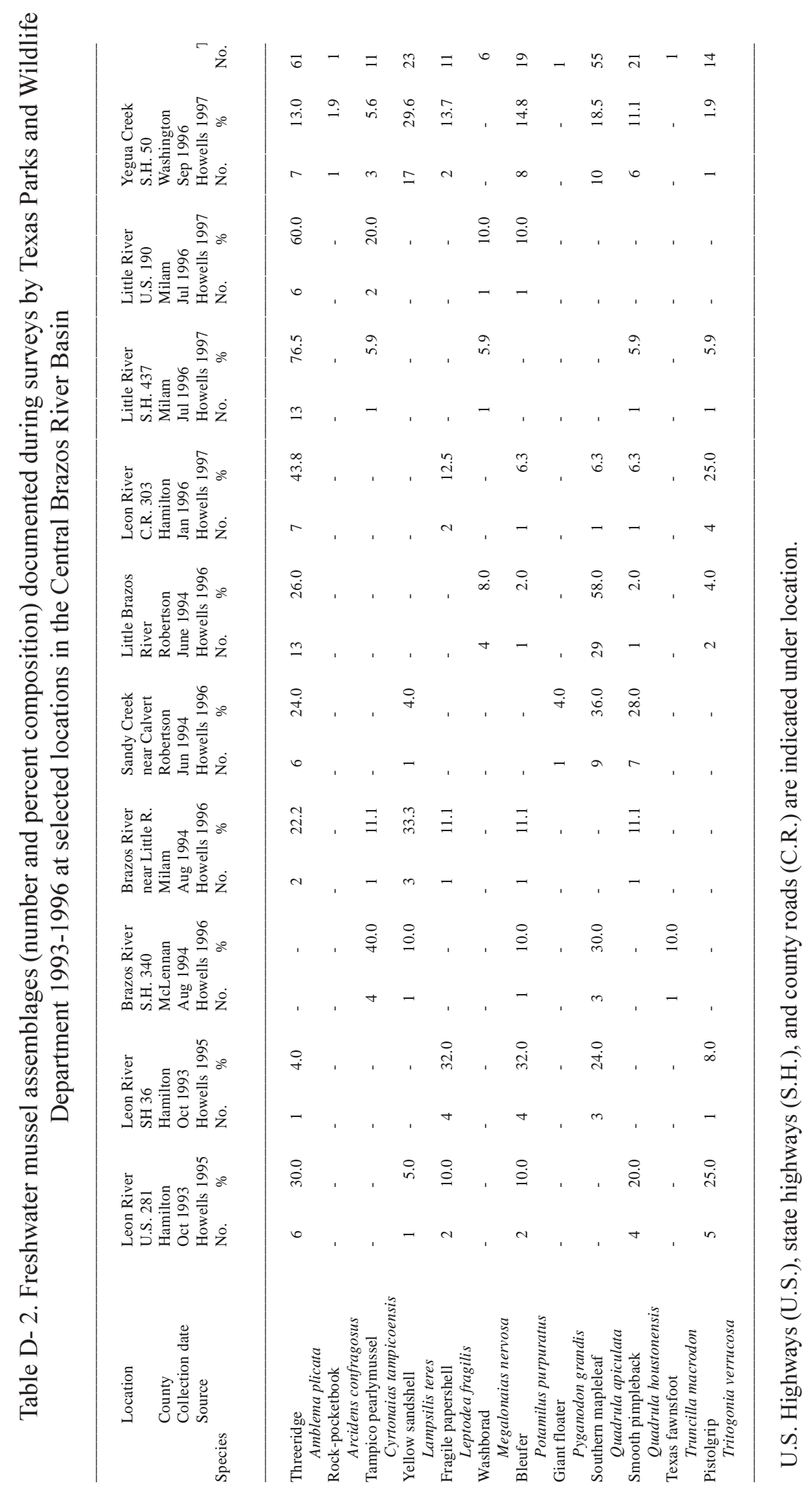


smooth pimpleback found the areas less acceptable, southern mapleleaf may have found conditions advantageous. Despite current environmental problems, southern mapleleaf remains one of the most abundant unionids statewide.

It should be noted that although current sampling efforts directed at living populations and more-recent shell deposits make an effort to evaluate all species and sizes present, prehistoric harvest may have focused on specific species and sizes to the exclusion of others. Native Americans may have deliberately selected for smooth pimplebacks and against southern mapleleafs, for example. Abundance in archeological samples would then provide a misleading guide to relative abundance among mussel assemblages of the time. This issue typically remains unresolved unless harvested and associated natural shell deposits can be compared.

Environmentally, all of the unionid species present evolved in flowing waters (and all, except false spike, are known to tolerate impoundment). They are most often associated with gravel, stable sand, and mud substrates in permanent-water conditions. None are typical of ponds, oxbows, canals, temporary waters, or bottoms of silt, deep-shifting sands, or scoured cobble and bedrock. Most probably favor gravel riffles and bars.

Other unionid species known from the Central Brazos River Drainage (Table D-2; Howells et al. 1996) that were not present in the current set of samples may have been absent for a number of reasons. Harvest appears to have centered on stream and river areas and not ponds or temporary waters where species like pond mussel (Ligumia subrostrata) and pondhorns (Uniomerus spp.) would have occurred. Species from such habitats were not recovered. Unionid taxa taken were also thicker-shelled species that are more likely to survive than thinnershelled taxa like giant floater (Pyganodon grandis) and fragile papershell (Leptodea fragilis) that often crack and disintegrate upon drying. These thinner shells may not have survived to the present as readily as heavier, thicker shells. Additionally, it is possible some species were deliberately selected against for a variety of reasons, including taste. Some, like washboard (Megalonaias nervosa), often occupy deeper waters and are less mobile. Both traits may then make them less likely to have been harvested than species found in shallower waters.

Although the valves and shells recovered from these sites were in relatively good condition compared to those from some other archeological sites, shell margins were worn in nearly every case. This, in turn, confounded attempts at assigning season of harvest to the specimens. Further, seasonality has yet to be demonstrated among unionid bivalves in Texas and growth-rest lines on shells of modern specimens suggest confident seasonality assignment locally is probably not possible (Texas Parks and Wildlife Department, unpublished data). 


\section{References Cited}

Howells, R. G.

1995 Distributional surveys of freshwater bivalves in Texas: progress report for 1993. Texas Parks and Wildlife Department, Management Data Series 119, Austin.

Howells, R. G.

1996 Distributional surveys of freshwater bivalves in Texas: progress report for 1994. Texas Parks and Wildlife Department, Management Data Series 120, Austin.

Howells, R. G.

1997 Distributional surveys of freshwater bivalves in Texas: progress report for 1996. Texas Parks and Wildlife Department, Management Data Series 144, Austin.

Howells, R. G., C. M. Mather, and J. A. M. Bergmann

1997 Conservation Status of Selected Freshwater Mussels in Texas. In Conservation and Management of Freshwater Mussels II: Initiatives for the Future, edited by K. S. Cummings, A. C. Buchanan, C. A. Mayer, and T. J. Naimo, pp. 117-127. Proceedings of a UMRCC Symposium, 16-18 October 1995. Upper Mississippi Conservation Committee, Rock Island, Illinois.

Howells, R. G., R. W. Neck, and H. D. Murray

1996 Freshwater Mussels of Texas. Texas Parks and Wildlife Press, Austin.

Neck, R. W.

1982 A Review of Interactions Between Humans and Freshwater Mussels in Texas. In Proceedings of the Symposium on Recent Benthological Investigations in Texas and Adjacent States, edited by J. R. Davis, pp. 169-182. Texas Academy of Science, Austin.

Neves, R. J.

1993 A State of the Unionids Address. In Conservation and Management of Freshwater Mussels, edited by K. S. Cummings, A. C. Buchanan, and L. M. Koch, pp. 1-10. Proceeding of a UMRCC Symposium, 12-14 October 1992. Upper Mississippi River Conservation Committee, Rock Island, Illinois.

Strecker, J.

1931 The Distribution of Naiades or Pearly Fresh-Water Mussels of Texas. Baylor University Museum, Bulletin 2, Waco.

Williams, J. D., M. L. Warren, Jr., K. S. Cummings, J. L. Harris, and R. J. Neves

1993 Conservation status of freshwater mussels of the United States and Canada. Fisheries (Bethesda) 18(9):6-22. 


\title{
Appendix E
}

\section{Macrobotanical Analysis of Flotation Samples}

\author{
J. Philip Dering
}




\title{
Appendix E: Macrobotanical Analysis of Flotation Samples
}

\author{
J. Philip Dering
}

\section{Macrobotanical Analysis of Flotation Samples from the Little River Testing Project, 41 MM340}

This report presents results of the macrobotanical analysis of five flotation samples that were recovered during test excavations conducted at 41MM340. The botanical assemblage from the site is evaluated for its potential to yield significant botanical data.

\section{Laboratory Methods}

Flotation samples are samples of archaeological sediment that have been floated in water to separate lighter charred plant remains from heavy material such as rock or caliche, and to remove lighter material such as clays/ silts that can be suspended in water and rinsed out of the sample. The light plant material is usually caught on fine-mesh material such as cheesecloth, or on very fine-mesh screen smaller than $0.450 \mathrm{~mm}$. The sediment samples were floated by personnel from the Center for Archaeological Research at The University of Texas at San Antonio.

Standard archaeobotanical laboratory procedures were followed during analysis. The samples were first opened and dried in an herbarium dryer. Then each sample was sorted through a series of four nested geological screens with mesh sizes of 4-mm, 2-mm, 1-mm, and $0.450-\mathrm{mm}$. The material caught on all of the sieve levels, including the pan was scanned for floral parts, fruits, and seeds. Usually only the wood fragments caught on the 4-mm and 2-mm screens are separated and identified, because it is extremely difficult and time consuming to identify wood fragments smaller than $2 \mathrm{~mm}$. Many times the diagnostic characteristics are not present in fragments smaller than 2-4-mm. The samples from 41MM340 were so small that it was decided to examine as much of the material caught on the 1-mm screen as possible. In this manner one more identification was secured.

Due to the poor preservation encountered at most open sites, only carbonized plant remains were considered for inclusion in the archaeological assemblage. Identification of all carbonized wood is accomplished by using the snap technique, examining them at 8 to 45 magnifications with a hand lens or a binocular dissecting microscope, and comparing them to samples in the herbarium at the Texas A\&M University. Identifications are made using reference collections at Texas A\&M University.

\section{Results of the Macrobotanical Analysis}

Archaeobotanical Assemblage

The highly reduced nature of the plant assemblage, both in quantity and in the size of the material, resulted in very few identifications. Three plant taxa were noted in the samples, oak wood, Ilex sp. (holly or haw) wood, and a possible pecan nut fragment (Table E-1). Plant parts noted in the samples included charred wood and nut fragments. All material labeled nut fragment refers to the outer pericarp of the nut.

The samples contained 17 wood fragments weighing approximately 0.3 grams, one cf. pecan fragment, and seven indeterminate nut fragments for a total of 25 charred plant fragments (Table E-2). Wood taxa represented in the samples were oak and Ilex sp. (possibly Ilex decidua or possum haw). Ilex sp. was noted in Lot 173, and 
Table E-1. Plant taxa identified in the samples

\begin{tabular}{|l|l|l|}
\hline \multicolumn{1}{|c|}{ Taxon } & \multicolumn{1}{c|}{ Common Name } & \multicolumn{1}{c|}{ Part } \\
\hline cf. Carya illinoiensis & Pecan & Nut fragment \\
\hline Thin nutshell & & Nut fragment \\
\hline Ouercus sp. & Oak & Wood \\
\hline Ilex sp. & Holly possum haw & Wood \\
\hline
\end{tabular}

oak was noted in Lots 75 and 222. Only two fragments of wood were larger than $3 \mathrm{~mm}$ and each of these larger fragments measured less than $4 \mathrm{~mm}$ in length. A single charred thin nut fragment, possibly pecan, was recovered from Lot 222. Other thin nut fragments too small to identify were noted in Lot 170 and Lot 173 . All of the nut fragments were smaller than $3 \mathrm{~mm}$ in length. Thin nut fragments usually represent pecan, and thicker nut fragments a type of hickory. In this case all of the plant material was too small to provide positive identifications.

The few nut fragments recovered from Lots 170, 173, and 222 provide some evidence suggesting that nut processing may have occurred at the site. Although such a small quantity of fragments could easily have been incorporated into the fire incidentally with a load of fuel wood, nut processing at the site should be considered as a possibility. Nut processing is usually accomplished using groundstone tools including nutting stones/manos and metates. The ethnographic record indicates that hickory is usually processed into oil (Talalay et al. 1984). Processing techniques for pecans are poorly recorded, but pecan shell fragments have been recovered from sheltered sites in Val Verde County (Baker Cave).

According to Hall (2000) there is no direct archeological or ethnohistorical evidence for processing pecan into oil as is commonly recorded for hickory. Hickory nuts are usually pounded using manos and anvil stones and then boiled to separate the oil. The proximity to fire increases the opportunity for the charring of the thick hickory shell (pericarp). Pecans may be stored in the shell for at least a year in an adequate setting, and the Payaya Indians of southern Texas stored pecans in pits, possibly to compensate for the reduced pecan productivity encountered after years of bounty (Hall 2000). Because pecans may not be processed around heating features like hickory, the chances for recovering charred pecan fragments may be reduced. Therefore the possible occurrence of pecan shell at open archaeological sites is noteworthy.

Table E-2. Flotation samples, provenience, liters floated, and identifications

\begin{tabular}{|c|c|c|c|c|c|c|c|c|c|c|}
\hline Lot \# & Block & Unit & Level & Elevation & Zone & Plant & Part & Count & Weight (g) & \begin{tabular}{|c|} 
Sample Fraction and \\
Material Size
\end{tabular} \\
\hline 75 & 3 & $\mathrm{C}$ & 2 & $60-70$ & 2 & Oak & Wood & 4 & $\leq .1$ & $\mathrm{LF}$ \\
\hline 117 & 3 & $\mathrm{C}$ & 2 & $81 / 91$ & 4 & NICPR* & & & & Flecks $<1 \mathrm{~mm}$ \\
\hline 173 & 3 & $\mathrm{C}$ & 1 & $94 / 104$ & 6 & $\begin{array}{l}\text { Ilex sp. } \\
\text { Indeterminate }\end{array}$ & $\begin{array}{l}\text { Wood } \\
\text { Thin nut frag. }\end{array}$ & $\begin{array}{c}12 \\
1 \\
\end{array}$ & $\begin{array}{l}<.1 \\
<.1 \\
\end{array}$ & $\begin{array}{l}\text { LF } \\
\mathrm{LF}(2 \mathrm{~mm}) \\
\end{array}$ \\
\hline 222 & 3 & $\mathrm{C}$ & 2 & $124 / 134$ & 8 & $\begin{array}{l}\text { Pecan (cf.) } \\
\text { Oak } \\
\text { Indeterminate } \\
\end{array}$ & $\begin{array}{l}\text { Thin nut frag. } \\
\text { Wood } \\
\text { Flecks }\end{array}$ & $\begin{array}{l}1 \\
1\end{array}$ & $\begin{array}{l}<.1 \\
<.1\end{array}$ & $\begin{array}{l}\mathrm{LF}(3 \mathrm{~mm}) \\
\mathrm{LF}(2 \mathrm{~mm}) \\
\mathrm{LF} \text { Flecks }<1 \mathrm{~mm}\end{array}$ \\
\hline 170 & 1 & $\mathrm{~B}$ & 6 & $50-60$ & & Indeterminate & Thin nut frag. & 6 & $<.1$ & HF Fragments $<2 \mathrm{~mm}$ \\
\hline & & & & & & & Total Fragments & 25 & & \\
\hline
\end{tabular}

* indicates samples with no identifiable carbonized plant remains.

The first four samples are from 41MM340, the last sample is from $41 \mathrm{MM} 341$. 


\section{Conclusion}

Although the archaeobotanical assemblage from 41MM340 flotation samples is somewhat reduced, the botanical data have yielded some promising results. Nut fragments (pericarp fragments) were recovered from three of the five (60 percent) flotation samples examined. At least two nut types, thin (cf. pecan) and thick (cf. hickory), were identified in the assemblage.

The results from the wood charcoal study were not as promising. The wood assemblage was reduced and of the 25 wood fragments noted in the flotation samples only two were larger than $2 \mathrm{~mm}$ long. The rest of the charred wood material that I attempted to identify ranged between 1 and $2 \mathrm{~mm}$ in length, making the process of identification very difficult. One of the five samples contained only small flecks of charcoal of insufficient size for identification.

There are, however, a total of 76 (66 from 41MM340, 10 from 41MM341) charcoal samples that were collected by CAR-UTSA during the excavation that have not yet been submitted for analysis (Steve Tomka, personal communication, 2000). These samples contain larger quantities of both wood and nut fragments than were noted in the floatation samples. If subsequent studies are authorized, these samples should be considered for analysis because the floatation samples have demonstrated that the site has the potential to generate botanical data. Furthermore, other areas located within the site may contain pockets of improved plant preservation. As a result, it will be critical for archaeologists to monitor the recovery of plant remains from the site if further work is recommended, because pockets of improved preservation may be encountered.

\section{References Cited}

Hall, G.

2000 Pecan Food Potential in Prehistoric North America. Economic Botany 54(1):103-112.

Talalay, L., D. R. Keller, and P. J. Munson

1984 Hickory Nuts, Walnuts, Butternuts, and Hazelnuts: Observations and Experiments Relevant to Their Aboriginal Exploitation in Eastern North America. In Experiments and Observations on Aboriginal Wild Plant Food Utilization in Eastern North America, edited by P. J. Munson, pp. 338-359. Prehistory Research Series 6(2). Indiana Historical Society. Indianapolis, Indiana. 


\section{Appendix F}

\section{Pollen and Phytolith Results}

John G. Jones 


\title{
Appendix F: Pollen and Phytolith Results
}

\author{
John G. Jones
}

I have completed the pollen and phytolith evaluation from site 41MM340 and 41MM341. In all cases, pollen grains were noted, but were poorly preserved and would probably not provide valid information on past environmental conditions. Phytoliths likewise were poorly preserved reflecting the harsh environmental conditions in the site area. It is my opinion that pollen and phytolith analyses from these sites are not warranted.

Both fossil pollen and phytoliths suffer from degradation caused by oxidizing conditions. In the case of pollen, these conditions (i.e., high $\mathrm{pH}$ and cyclic wetting and drying) favor fungal and bacterial growth which can destroy pollen. Phytoliths are also negatively effected from oxidizing conditions, especially in areas with high $\mathrm{pH}$ values. Recognizing that the environmental conditions in Milam county well match the above criteria, conservative processing techniques were employed in the extraction of the pollen and phytoliths.

Pollen was isolated using standard techniques employed at the Texas A\&M University Palynology Laboratory. Exotic tracer spores were added to a standard volume of sediment $(15 \mathrm{mls})$. The sample was then rinsed with $\mathrm{HCl}, \mathrm{HF}$, an acetolysis treatment, a wash in dilute $\mathrm{KOH}$ and a heavy density separation using $\mathrm{ZnBr}$ (Sp.G. 2.00). Residues were dehydrated in alcohol and were transferred to 1 dram vials for storage in glycerin. Slides were prepared using glycerin as a mounting media.

Phytoliths were also quantified (10 grams), rinsed in HCl, oxidized both Schulze's solution (concentrated Nitric Acid and Potassium Chlorate) and then in $5 \% \mathrm{KOH}$. The lighter phytoliths were isolated from inorganic silicates using a heavy density separation with $\mathrm{ZnBr}$ (Sp.G. 2.38). The phytoliths were collected, rinsed, and mounted on permanent slides using Meltmount adhesive. Examinations of both pollen and phytoliths were made on a Jenaval compound stereomicroscope at 400x magnification.

Pollen was noted in all of the samples, and at least 13 different taxa were noted, including oaks, pines, junipers, ephedra, grasses, composites, thistles, goosefoot, lily, sedge, buttonbush and willow. However, nearly all grains were poorly preserved and most of the taxa recorded represent species that are especially abundant in the environment and are quite durable and easily recognized when degraded. Through the addition of exotic tracer spores, I was able to calculate the concentration values for the samples. These values ranged from 936 to 2250 fossil grains per $\mathrm{ml}$ of sediment. These values are considered quite low, and interpretations based on these pollen counts must be suspect. In short, although some fossil pollen remains in the archaeological sediments from these sites, little information could be obtained from a detailed pollen analysis of these sediments.

Phytoliths were extremely rare in the sediments from these sites. When noted, most phytoliths were highly degraded indicating that fossil biosilicates have been lost from the sediments. Conditions affecting phytolith preservation are imperfectly understood, but it is known that highly oxidizing conditions in areas with a high $\mathrm{pH}$ can result in total phytolith loss.

Although the examination of the microfossils was not encouraging, it is important to continue testing different regions as micro-edaphic conditions frequently allow for pollen and phytolith preservation in regions where one would not expect them to be found. 


\title{
Appendix G
}

\section{Gastropod Analysis}

\author{
Richard W. Fullington
}




\title{
Appendix G: Gastropod Analysis
}

\author{
Richard W. Fullington, Ph.D.
}

\section{Site $41 M M 340$}

\section{Summary}

A total of 1,640 gastropod shells were examined from six lots. Thirteen species were identified representing ten families (Table G-1). All shells were in excellent condition and coloration is still remarkably good. Literature records indicate that a number of the site species can be found today in the immediate area with the exception of Carychium mexicanum and Haplotrema concavum (Cheatum and Fullington, 1971, 1973; Fullington and Pratt 1974).

Climatically and environmentally, there appears to have been little change through the time period covered by the examined levels (50-134 cm bs) (Table G-2). The site area was heavily forested with a deep leaf litter floor — six of the site species prefer this type of habitat. There were open, grassy areas adjacent to these woods — six of the site species prefer this type of habitat. In summary, the area was a benched terrace with a riparian woodland adjacent to a relatively slow moving stream. The one aquatic gastropod, Helisoma trivolvis lentum, prefers this type of aquatic habitat. Carychium mexicanum occurs in deep, constantly moist leaf litter and in moss alongside a stream.

The high numbers of Rabdotus dealbatus dealbatus found in Block 3, Zone 4, elevation 124-134 may indicate the presence of a trash pit. Terrestrial gastropods tend to be attracted by organic debris. The author has observed this phenomena many times during collection trips. Roadside dumps are a bonanza for snail collecting.

\section{Methodology}

Lots 64, 181 and 235 were sifted through 3/4-inch screen and Lots 104, 173 and 222 were recovered from flotation processing and fine screening. The shells were examined through a standard field microscope (20x). All samples are from Block 3, Units C and B.

\section{Data Analysis}

The gastropod shells examined from Site 41MM340 appear to have been primarily deposited in situ and not from flood deposition. If this had been the case, the numbers of shells and species would have been much higher and there would have been more aquatic species found. There was little difference in the number of shells found between cultural and non-cultural zones. This indicates that the occupational sites were not heavily populated nor inhabited for lengthy periods of time (personal research).

The presence of the predatory snail, Haplotrema concavum, is indicative of a stable and long term gastropod community. It is a voracious feeder and occurs only where there are large and stable populations of snails. 
Table G-1. Identification of gastropod shell remains recovered from 41MM340

\begin{tabular}{|c|c|}
\hline \multicolumn{2}{|l|}{ Family Carychiidae } \\
\hline Carychium mexicanum (Pilsbry) & 6 \\
\hline \multicolumn{2}{|l|}{ Family Pupillidae } \\
\hline Gastrocopta contracta (Say) & 26 \\
\hline Gastrocopta pellucida hordeacella (Pilsbry) & 2 \\
\hline \multicolumn{2}{|l|}{ Family Haplotrematidae } \\
\hline Haplotrema concavum (Say) & 1 \\
\hline \multicolumn{2}{|l|}{ Family Zonitidae } \\
\hline Hawaiia minuscula (Binney) & 49 \\
\hline Zonitoides arboreus (Say) & 13 \\
\hline \multicolumn{2}{|l|}{ Family Helicinidae } \\
\hline Helicina orbiculata tropica (Say) & 252 \\
\hline \multicolumn{2}{|l|}{ Family Endodontidae } \\
\hline Helicodiscus parallelus (Say) & 7 \\
\hline \multicolumn{2}{|l|}{ Family Polygyridae } \\
\hline Polygyra mooreana (Binney) & 8 \\
\hline Praticolella berlandieriana (Moricand) & 2 \\
\hline \multicolumn{2}{|l|}{ Family Bulimulidae } \\
\hline Rabdotus dealbatus dealbatus (Say) & 1,233 \\
\hline \multicolumn{2}{|l|}{ Family Strobilopsidae } \\
\hline Strobilops texasiana (Pilsbry \& Ferriss) & 40 \\
\hline Aquatic Gastropoda & \\
\hline \multicolumn{2}{|l|}{ Family Planordidae (Aquatic) } \\
\hline Helisoma trivolvis lentum (Say) & 1 \\
\hline Total & 1,640 \\
\hline
\end{tabular}

\section{Habitat Preferences}

Densely wooded forest with deep, moist leaf litter and fallen logs:
Strobilops texasiana
Helicodiscus parallelus
Hawaiia minuscula
Gastropcopta contracta
Haplotrema concavum

Open grassy areas to sparsely wooded areas:

\section{Rabdotus dealbatus dealbatus \\ Polygyra mooreana \\ Praticolella berlandieriana}

Helicina orbiculata tropica

Gastrocopta pellucida hordeacella

Zonitioides arboreus

Moss adjacent to flowing water to very moist forest floor:

\section{Carychium mexicanum}

Potamon stream with emergent littoral emergent vegetation:

Helisom trivolvis lentum 
Table G-2. Distribution of selected gastropod shell remains recovered from 41MM340

Gastropod Data by Lots

\begin{tabular}{|c|c|c|c|c|c|c|c|c|}
\hline Lot & Block & Unit & Zone & Level & Elevation & Species & Number & Taphonomy \\
\hline \multirow[t]{2}{*}{64} & 3 & $\mathrm{C}$ & 2 & 6 & $50-60$ & Helicina orbiculata tropica & 130 & \\
\hline & & & & & & \multirow{2}{*}{ Subtotal } & $\frac{130}{130}$ & \\
\hline \multirow[b]{2}{*}{104} & & & & & & & & \\
\hline & 3 & $\mathrm{C}$ & 3 & 9 & $80-90$ & Helicina orbiculata tropica & 6 & \\
\hline 104 & 3 & $\mathrm{C}$ & 3 & 9 & $80-90$ & Carychium mexicanum & 3 & \\
\hline 104 & 3 & $\mathrm{C}$ & 3 & 9 & $80-90$ & Srobilops texasiana & 21 & \\
\hline 104 & 3 & $\mathrm{C}$ & 3 & 9 & $80-90$ & Gastrocopta contracta & 8 & \\
\hline 104 & 3 & $\mathrm{C}$ & 3 & 9 & $80-90$ & \multirow{2}{*}{ Gastrocopta pellucida hordeacella } & 2 & \\
\hline 104 & 3 & $\mathrm{C}$ & 3 & 9 & $80-90$ & & 5 & \\
\hline 104 & 3 & $\mathrm{C}$ & 3 & 9 & $80-90$ & Hawaiia minuscula & 18 & \\
\hline \multirow[t]{2}{*}{104} & 3 & $\mathrm{C}$ & 3 & 9 & $80-90$ & Helicodiscus parallelus & 3 & \\
\hline & & & & & & \multirow[t]{2}{*}{ Subtotal } & 66 & \\
\hline & & & & & & & & \\
\hline 173 & 3 & $\mathrm{C}$ & 4 & $10: 11$ & 94-104 & Helicina orbiculata tropica & 2 & \\
\hline 173 & 3 & $\mathrm{C}$ & 4 & $10: 11$ & 94-104 & Carychium mexicanum & 2 & \\
\hline 173 & 3 & $\mathrm{C}$ & 4 & $10: 11$ & 94-104 & Strobilops texasiana & 16 & \\
\hline 173 & 3 & $\mathrm{C}$ & 4 & $10: 11$ & $94-104$ & Gastrocopta contracta & 14 & \\
\hline 173 & 3 & $\mathrm{C}$ & 4 & $10: 11$ & $94-104$ & Zonitoides arboreus & 5 & \\
\hline 173 & 3 & $\mathrm{C}$ & 4 & $10: 11$ & 94-104 & Hawaiia minuscula & 20 & \\
\hline 173 & 3 & $\mathrm{C}$ & 4 & $10: 11$ & 94-104 & Helicodiscus parallelus & 4 & \\
\hline & & & & & & \multirow[t]{2}{*}{ Subtotal } & 63 & \\
\hline & & & & & & & & \\
\hline 181 & 3 & $\mathrm{~B}$ & 4 & $10: 11$ & $94-104$ & Rabdotus dealbatus dealbatus & 19 & \\
\hline 181 & 3 & $\mathrm{~B}$ & 4 & $10: 11$ & $94-104$ & Helicina orbiculata tropica & 68 & \\
\hline 181 & 3 & $\mathrm{~B}$ & 4 & $10: 11$ & $94-104$ & Polygyra mooreana & 7 & \\
\hline 181 & 3 & $\mathrm{~B}$ & 4 & 10:11 & 94-104 & Haplotrema concavum & 1 & Predatory land snail \\
\hline & & & & & & Subtotal & 95 & \\
\hline & & & & & & & & \\
\hline 222 & 3 & $\mathrm{C}$ & 6 & $13: 14$ & 124-134 & Rabdotus dealbatus dealbatus & 4 & \\
\hline 222 & 3 & $\mathrm{C}$ & 6 & 13:14 & 124-134 & Helicina orbiculata tropica & 3 & \\
\hline 222 & 3 & $\mathrm{C}$ & 6 & $13: 14$ & 124-134 & Carychium mexicanum & 1 & \\
\hline 222 & 3 & $\mathrm{C}$ & 6 & $13: 14$ & $124-134$ & Strobilops texasiana & 3 & \\
\hline 222 & 3 & $\mathrm{C}$ & 6 & $13: 14$ & $124-134$ & Gastrocopta contracta & 4 & \\
\hline 222 & 3 & $\mathrm{C}$ & 6 & $13: 14$ & 124-134 & Zonitoides arboreus & 3 & \\
\hline 222 & 3 & $\mathrm{C}$ & 6 & $13: 14$ & $124-134$ & Hawaiia minuscula & 11 & \\
\hline & & & & & & Subtotal & 29 & \\
\hline & & & & & & & & \\
\hline 235 & 3 & $\mathrm{~B}$ & 4 & $13: 14$ & 124-134 & Rabdotus dealbatus dealbatus & 1,210 & \\
\hline 235 & 3 & $\mathrm{~B}$ & 4 & $13: 14$ & $124-134$ & Helicina orbiculata tropica & 43 & \\
\hline 235 & 3 & B & 4 & 13:14 & $124-134$ & Praticolella berlandieriana & 2 & \\
\hline 235 & 3 & $\mathrm{~B}$ & 4 & $13: 14$ & $124-134$ & Helisoma trivolvis lentum & 1 & Aquatic \\
\hline 235 & 3 & $\mathrm{~B}$ & 4 & $13: 14$ & 124-134 & Polvgyra mooreana & 1 & \\
\hline & & & & & & Subtotal & 1,257 & \\
\hline & & & & & & Grand Total & 1,640 & \\
\hline
\end{tabular}




\section{Site $41 M M 341$}

\section{Summary}

A total of 195 gastropod shells were examined from 1 lot. Eleven species were identified representing eight families (Table G-3). All shells were in excellent condition and coloration is still remarkably good. Virtually all of the site species can be found today in the immediate area with the exception of Carychium mexicanum and Haplotrema concavum (Cheatum and Fullington, 1971, 1973; Fullington and Pratt 1974).

Climatically and environmentally, there appears to have been little change through the time period covered by the examined levels (50-60 cm bs) (Tables G-4). The Site area was heavily forested with a deep leaf litter floor - seven of the site species prefer this type of habitat. There were open, grassy areas adjacent to these woods four of the site species prefer this type of habitat. In summary, the area was a benched terrace with a riparian woodland adjacent to a relative slow moving stream. Carychium mexicanum occurs in deep, constantly moist leaf litter and in moss alongside a stream. Exposed, wooded limestone outcroppings must have been nearby due to the presence of Anquispira alternata which inhabits this type of environment.

\section{Methodology}

Soil samples from Lot 34 were sifted through 1/4-inch screen and shells from Lot 170 was recovered from flotation processing and fine screening. The shells were examined through a standard field microscope (20x). All samples are from Block 1, Units B and D.

\section{Data Analysis}

The gastropod shells examined from Site 41MM341 appear to have been primarily deposited in situ and not from flood deposition. If this had been the case, the numbers of shells and species would have been much higher and there would have been more aquatic species found. There was little difference in the number of shells found between cultural and non-cultural zones. This indicates that the occupational sites were not heavily populated nor inhabited for lengthy periods of time (personal research).

The presence of the predatory snail, Haplotrema concavum, is indicative of a stable and long term gastropod community. It is a voracious feeder and occurs only where there are large populations of snails.

Given the amount of data that was gleaned from a small sampling, site 41MM341 is well worth further investigation. The knowledge that the snail populations appear to have been deposited in situ provides an opportunity to further investigate the relationship of primitive people and their impact on the immediate environment. The Site also represents an opportunity to clarify some the site occupants activities through the terrestrial gastropods. 
Table G-3. Identification of gastropod shell remains recovered from 41MM341

\begin{tabular}{|l|r|}
\hline Family Carychiidae & \\
\hline Carychium mexicanum (Pilsbry) & 63 \\
\hline & \\
\hline Family Pupilidae & 28 \\
\hline Gastrocopta contracta (Say) & 7 \\
\hline Gastrocopta pellucida hordeacella (Pilsbry) & \\
\hline & \\
\hline Family Haplotrematidae & \\
\hline Haplotrema concavum (Say) & \\
\hline & \\
\hline Family Zonitidae & 32 \\
\hline Hawaiia minuscula (Binney) & 11 \\
\hline Zonitoides arboreus (Say) & \\
\hline Euconulus fulvus (Mueller) & \\
\hline & \\
\hline Family Helicinidae & \\
\hline Helicina orbiculata tropica (Say) & \\
\hline & \\
\hline Family Endodontidae & \\
\hline Anguispira alternata (Morse) & \\
\hline & \\
\hline Family Bulimulidae & \\
\hline Rabdotus dealbatus dealbatus (Say) & \\
\hline & \\
\hline Family Strobilopsidae & \\
\hline Strobilops texasiana (Pilsbry \& Ferriss) & \\
\hline & \\
\hline
\end{tabular}

\section{Habitat Preferences}

Densely wooded Forest with deep, moist leaf litter and fallen logs:
Strobilops texasiana
Helicodiscus parallelus
Hawaiia minuscula
Gastropcopta contracta
Haplotrema concavum
Euconulus fulvus

Open grassy areas to sparsely wooded areas:
Rabdotus dealbatus dealbatus
Polygyra mooreana
Praticolella berlandieriana
Helicina orbiculata tropica
Gastrocopta pellucida hordeacella
Zonitioides arboreus

Moss adjacent to flowing water to very moist forest floor:

\section{Carychium mexicanum}

Sloping hillsides with brush or trees (terrace slopes, limestone outcroppings):

\section{Anguispira alternata}


Table G-4. Distribution of selected gastropod shell remains recovered from 41MM341

Gastropod Data by Lots

\begin{tabular}{|c|c|c|c|c|c|c|c|}
\hline Lot & Block & Unit & Level & Elevation & Species & Number & Taphonomy \\
\hline 34 & 1 & $\mathrm{D}$ & 6 & $50-60$ & Rabdotus dealbatus dealbatus & 5 & Larger \& older appearing than 340 \\
\hline 34 & 1 & $\mathrm{D}$ & 6 & $50-60$ & Helicina orbiculata tropica & 3 & \\
\hline 34 & 1 & $\mathrm{D}$ & 6 & $50-60$ & Haplotrema concavum & 2 & Predatory land snail \\
\hline 34 & 1 & $\mathrm{D}$ & 6 & $50-60$ & Anguispira alternata & 1 & Orange still bright \\
\hline & & & & & Total & 11 & \\
\hline 170 & 1 & $B$ & 6 & $50-60$ & Carychium mexicanum & 63 & \\
\hline 170 & 1 & B & 6 & $50-60$ & Strobilops texasiana & 39 & \\
\hline 170 & 1 & B & 6 & $50-60$ & Euconulus fulvus & 1 & \\
\hline 170 & 1 & $\mathrm{~B}$ & 6 & $50-60$ & Gastrocopta contracta & 28 & \\
\hline 170 & 1 & B & 6 & $50-60$ & Gastrocopta pellucida hordeacella & 7 & \\
\hline 170 & 1 & B & 6 & $50-60$ & Zonitoides arboreus & 11 & \\
\hline 170 & 1 & B & 6 & $50-60$ & Hawaiia minuscula & 32 & \\
\hline & & & & & Total & 181 & \\
\hline
\end{tabular}

\title{
Future Site Investigation Recommendations
}

\author{
(Sites 41MM340, 41MM341)
}

Given the amount of data that was gleaned from a small sampling, Site 41MM340 is well worth further investigation. The knowledge that the snail populations appear to have been deposited in situ provides an opportunity to further investigate the relationship of primitive people and their impact on the immediate environment. The site also represents an opportunity to clarify some the site occupant's activities through the terrestrial gastropods.

Shell preservation is exceptionally good as is shell coloration and there appears to be a drying trend upwards through the site strata. This possibility also should be pursued with further site investigation.

Other future site investigations should include the following:

Survey of the existing gastropod fauna

Develop a single vertical column through the site strata to obtain a complete linear time line. Pollen samples should be taken from this column.

Develop a column through cultural layers and another column away from the cultural activity to test for human impact on the local fauna

The possible utilization of Rabdotus dealbatus as a food source by the site occupants 


\section{References Cited}

Cheatum, E. P., and R. W. Fullington

1971 Bulletin 1 The Aquatic and Land Mollusca of Texas. Part One: The Recent and Pleistocene Members of the Gastropod Family Polygyridae in Texas. DMNH, Dallas.

1973 Bulletin 1 The Aquatic and Land Mollusca of Texas. Part Two: The Recent and Pleistocene Members of the Pupillidae and Urocoptidae (Gastropoda) in Texas. DMNH, Dallas.

Fullington, R. W., and W. L. Pratt, Jr.,

1974 Bulletin 1 The Aquatic and Land Mollusca of Texas. Part Three: The Helicinidae, Carychiidae, Achatinidae, Bradybaenidae, Bulimulidae, Cionellidae, Haplotrematidae, Helicidae, Oreohelicidae, Spiraxidae, Streptaxidae, Strobilopsidae, Thysanophoridae, Valloniidae (Gastropoda) in Texas. DMNH, Dallas. 


\title{
Appendix H
}

\section{Diatom Paleoenvironmental Analysis of Sediments}

\author{
Barbara Winsborough
}




\title{
Appendix H: Diatom Paleoenvironmental Analysis of Sediments
}

\author{
Barbara Winsborough
}

\section{Introduction}

Diatoms are unicellular, eukaryotic, pigmented, photosynthetic algae distinguished by the possession of a cell wall that is heavily impregnated with silica. Some species are colonial, living in clusters, chains, or tubes, while others form zig-zag or star-shaped colonies. Many species produce extracellular mucilage pads, stalks, tubes, amorphous masses, strands, threads, or filaments that are composed of polysaccharide. Some diatom species are free-floating planktonic forms living much of their life suspended in the water column, and other species are benthic, either crawling unattached through sediments or spending their lives attached to a solid surface such as sand, pebble, rock, wood, rooted macrophyte, other algae, or floating mat. Most aerophilic species are motile and can glide over surfaces and through sediments for efficient light capture.

Diatoms can be found living in a wide variety of natural and man-made terrestrial and aquatic habitats, including seeps, wet walls, damp soil, caves, springs, streams, ponds, lakes, marshes, lagoons, estuaries, bogs, swamps, fens, ditches, canals, temporary pools, travertine accumulations, water and sewage treatment facilities, cooling towers, and hatcheries; on ice and snow; on turtles, whales, other mammals, invertebrates, and fish; and in estuaries, bays, oceans and seas. Most are cosmopolitan - found in many parts of the world under similar environmental conditions, and many species have predictable environmental requirements and pollution tolerance. Therefore water quality directly effects diatom species composition. Diatoms can be readily identified to species, and a large body of information exists on the range of ecological tolerance of many common species. Because diatoms are sensitive indicators of water chemistry, habitat, and substrate; are often found in large numbers in sedimentary deposits; can be identified to species; and are cosmopolitan in distribution, they are well-suited for use in paleoenvironmental reconstruction.

Eight sediment samples and five fired clay samples (Table H-1) from two archaeological sites near the town of Cameron, in Milam County east-central Texas, were submitted to Winsborough Consulting for diatom paleoenvironmental analysis. Three of the eight sediment samples were modern samples collected to establish a local modern analog data set. Water bodies and water chemistry have probably changed little within the time frame under consideration in this investigation. These samples include a phytoplankton and bottom sludge sample from the Little River, and the top $1 \mathrm{~cm}$ of soil from a modern slough surface $60 \mathrm{~m}$ south of 41MM340 (Table H-1). The sediment samples were processed in the manner described below. The baked clay samples were first soaked in concentrated HCL to disaggregate them, then rinsed prior to being cleaned with the usual protocol described below.

\section{Methods}

Observations are made on the diatom frustule after it is cleaned of its organic parts. A sample of sediment material measuring about a centimeter square was divided approximately in half, one half was cleaned and the other curated. Samples were cleaned of organic material and carbonate in preparation for microscopic analysis by boiling first in hydrogen peroxide and then in nitric acid. The oxidized, decalcified material was rinsed repeatedly until a $\mathrm{pH}$ of about 6-7 was reached. A few drops of the cleaned material was air-dried on to glass coverslips and mounted on glass slides using $\operatorname{HYRAX}^{\circ}$, a resin with a high index of refraction. Slides were scanned at 1500x and 2000 diatoms were counted from each sample. Diatom relative abundance is determined from a count of 500 cells, whenever possible. The data are tabulated and the paleoecological significance of the individual species considered in reconstruction of the environment. 
Table H-1. Samples recovered from 41MM340 and 41MM341 examined for diatom content

\begin{tabular}{|c|l|}
\hline Sample\# & \multicolumn{1}{|c|}{ Description } \\
\hline 1 & Modern phytoplankton from Little River at SH 77 crossing, collected 2-28-2000. \\
\hline 2 & Bottom sludge sample from Little River at SH 77 crossing. collected 2-28-2000. \\
\hline 3 & Top 1 cm of soil from modern slough located 60 m south of 41MM340, collected 2-28-2000. \\
\hline 4 & Sediment from 41MM341, 2 cm below cultural zone. \\
\hline 5 & Sediment from 41MM340, BHT A, south wall, zone 2. \\
\hline 6 & Sediment from 41MM340, block 3, zone 4, north wall. \\
\hline 7 & Sediment from 41MM340, block 3, zone 6, north wall. \\
\hline 8 & Sediment from 41MM340, block 3, zone 8, north wall. \\
\hline 9 & Fired clay nodules from 41MM340, lot 99, block 3, unit A, field zone 3-1, el. 70-80 cm. \\
\hline 10 & Fired clay nodules from 41MM340, lot 116, block 3, unit C, zone 4-1, el. 84-94 cm. \\
\hline 11 & Fired clay nodules from 41MM340, lot 185, block 3, unit A, zone 4-3, el. 94-104 cm. \\
\hline 12 & Fired clay nodules from 41MM340, lot 229, block 3, unit A, zone 6-1, el. 124-134 cm. \\
\hline 13 & Fired clay nodules from 41MM341, lot 67, block 2, unit B, zone 7, el. 60-70 cm. \\
\hline
\end{tabular}

\section{Results}

Overall, there were 69 species of diatoms recorded from the samples. The largest number of taxa was in the modern benthic sludge sample from the Little River, which had 59 species in a count of 500 cells (Table H-2). This is a diverse population and probably represents an entire year or more of diatom accumulation, including various seasons and microhabitats. The diatoms encountered in the modern Little River sample are a mixture of benthic stream species and aerial taxa found in wetlands, temporary pools, on moss and wet rocks and in soils. They indicate a $\mathrm{pH}$ of circumneutral to slightly alkaline, shallow water, and a muddy substrate with some vegetation. There were no clearly dominant species.

There were no diatoms in the phytoplankton sample. Phytoplankton populations often do not develop in small shallow streams with short residence times. Algal growth would be expected to be concentrated on the sediment surface and attached to the surface of vegetation on the bottom and sides of the stream.

The modern slough sample was diatomaceous, and had 10 species in it but the assemblage was heavily dominated by one diatom species, Craticula cuspidata. Craticula cuspidata is unusual among diatoms in that it lives in such habitats as temporary rainwater pools and saline pans in desert areas and forms internal 'shells' enabling it to remain alive in the dry state for several years. It may be an indicator of elevated salt concentrations.

The sediment samples $(4,5,6,7$, and 8$)$ were barren of diatoms, as well as phytoliths and pollen. If this material represents a flood deposit, it is not surprising that there would be very few diatoms if any in the material.

The fired clay nodules varied in their diatom content. Sample 9 was the most diatomaceous with 500 cells counted. It was also diverse, with 25 species recorded. These species are a mixture of aerophilic diatoms (found in soil and mud) and benthic aquatic species found attached to emergent vegetation and macroalgae. The assemblage suggests that the paleoenvironment was a very shallow, muddy habitat with some vegetation. Most significantly, the diatoms in this sample were still attached in chains of up to 4 individuals, they were whole, and showed no signs of abrasion or breakage typical of an assemblage that has been transported and is just detrital. The large number of individuals found is also inconsistent with a detrital deposit. Samples 11 and 12 contained only a few aerophilic diatoms. 
Table H-2. Identification of diatom samples recovered from Little River (modern) and sites 41MM340 and 41MM341

\begin{tabular}{|c|c|c|c|c|c|}
\hline Sample \# & 2 & 3 & 9 & 11 & 12 \\
\hline Achnanthes clevei & 2 & & & & \\
\hline Achnanthidium minutissium & 14 & & & & \\
\hline Amphora montana & 8 & & & & \\
\hline Amphora ovalis & 3 & 3 & 1 & & \\
\hline Amphora pediculus & 10 & & & & \\
\hline Amphora veneta & 1 & & & & \\
\hline Bacillaria paradoxa & 9 & & & & \\
\hline Caloneis bacillum & & & 22 & & \\
\hline Cocconeis placentula & 28 & & & & \\
\hline Craticula cuspidata & 25 & 476 & 1 & & \\
\hline Cyclotella atomus & 2 & & & & \\
\hline Cyclotella ocellata & 1 & & & & \\
\hline Cymatopleura solea & 2 & & & & \\
\hline Diadesmis confervacea & 17 & & & & \\
\hline Diadesmis gallica & & 3 & 2 & & \\
\hline Diatoma vulgare & 23 & & & & \\
\hline Diploneis parma & 7 & & 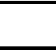 & & \\
\hline Encyonema silesiacum & 7 & & 1 & & \\
\hline Epithemia adnata & & & 4 & & \\
\hline Epithemia turgida & & & 4 & & \\
\hline Fragilaria ulna & 18 & & & 1 & \\
\hline Gomphonema angustum & 6 & & & & \\
\hline Gomphonema clavatum & 4 & & & & \\
\hline Gomphonema parvulum & 13 & & 19 & & \\
\hline Gyrosigma scalproides & 2 & 4 & & & \\
\hline Hantzschia amphioxys & & 2 & 82 & 1 & 2 \\
\hline Hippodenta capitata & 10 & & & & \\
\hline Hippodenta capitata var. hungarica & 2 & & & & \\
\hline Luticola mutica & 3 & 1 & 30 & 2 & \\
\hline Melosira varians & 18 & & & & \\
\hline Meridion circulare & & & 2 & & \\
\hline Navicula cryptocephala & 3 & & 11 & & \\
\hline Navicula cryptotenella & 7 & & 29 & & \\
\hline Navicula lenzii & 1 & & & & \\
\hline Navicula menisculus & 6 & & & & \\
\hline Navicula minima & 6 & & 6 & & \\
\hline Navicula pupula & 4 & & & & \\
\hline Navicula rhynchocephala & 8 & & 6 & & \\
\hline Navicula salinarum & 6 & & & & \\
\hline Navicula sanctaecrucis & 21 & & & & \\
\hline Navicula subminuscula & 9 & & & & \\
\hline Navicula symmetrica & 1 & & 2 & & \\
\hline Navicula texana & 12 & & 5 & & \\
\hline Navicula tripunctata & 25 & & 7 & & \\
\hline Navicula viridula & 7 & & & & \\
\hline
\end{tabular}


Table H-2. continued...

\begin{tabular}{|l|c|c|c|c|c|}
\hline \multicolumn{1}{|c|}{ Sample \# } & $\mathbf{2}$ & $\mathbf{3}$ & $\mathbf{9}$ & $\mathbf{1 1}$ & $\mathbf{1 2}$ \\
\hline Nitzschia acuminata & 3 & 1 & & & \\
\hline Nitzschia amphibia & 24 & 3 & 58 & & \\
\hline Nitzschia angustata & & 6 & & & \\
\hline Nitzschia compressa & 2 & & & & \\
\hline Nitzschia constricta & 5 & & & & \\
\hline Nitzschia dissipata & 16 & & 2 & & \\
\hline Nitzschia frustulum & 1 & & 4 & & \\
\hline Nitzschia inconspicua & 15 & & 4 & & \\
\hline Nitzschia levidensis & 2 & & & & \\
\hline Nitzschia linearis & 11 & & & & \\
\hline Nitzschia palea & 10 & & 111 & & \\
\hline Nitzschia solita & & & & & \\
\hline Pinnularia cf. viridis & & & & 2 & \\
\hline Plagiotropis lepidoptera var. proboscidea & 1 & 1 & & & \\
\hline Pleurosigma salinarum & 1 & & & & \\
\hline Pseudostaurosira brevistriata & 1 & & & & \\
\hline Reimeria sinuata & 15 & & & & \\
\hline Rhoicosphena curvata & 2 & & & & \\
\hline Rhopalodia brebissonii & 4 & & 52 & & \\
\hline Rhopalodia gibba & & & 35 & & \\
\hline Staurosira construens & 17 & & & & \\
\hline Surirella brebissonii & 7 & & & & \\
\hline Surirella minuta & 5 & & & & \\
\hline Surirella ovalis & 5 & & & & \\
\hline Total & $\mathbf{5 0 0}$ & $\mathbf{5 0 0}$ & $\mathbf{5 0 0}$ & $\mathbf{6}$ & $\mathbf{2}$ \\
\hline Note: Sample s, & & &
\end{tabular}

Note: Sample \#s 1, 4, 5, 6, 7, 8, 10, and 13 were barren of diatoms.

\section{Conclusions}

The most notable conclusion is that Sample 9, which represents fired clay nodules associated with archaeological hearth features, contains a concentration of diatoms that may have been transported to the site from a nearby stream during food preparation, possibly attached to mussels or other edible material. This provides confirmation that the feature was indeed a hearth impacted by human activities. 



\section{Appendix I}

\section{Amino Acid Racemization Values for Snail and Mussel Shell}




\section{Appendix I : Amino Acid Racemization Values for Snail and Mussel Shell}

Data supplied by Texas Department of Transportation

Table I-1. Snail Shell Ratios and ASP/GLU Ratios

\begin{tabular}{|c|c|c|c|c|c|}
\hline Lab\# & Lot \# & Zone & Polygyra mooreana & Praticolella berlandieriana & Aspartic acid/Glutamic acid \\
\hline CH-195 & 78 & 2 & 0.055 & & 1.081 \\
\hline CH-196 & 78 & 2 & 0.0385 & & 1.105 \\
\hline CH-197 & 78 & 2 & 0.0432 & & 1.068 \\
\hline CH-198 & 78 & 2 & 0.0415 & & 1.153 \\
\hline CH-199 & 78 & 2 & 0.0331 & & 1.088 \\
\hline CH-200 & 78 & 2 & 0.0294 & & 1.100 \\
\hline CH-201 & 78 & 2 & 0.0643 & & 1.116 \\
\hline CH-202 & 78 & 2 & & & 1.097 \\
\hline CH-163 & 150 & 4 & 0.0393 & & 1.179 \\
\hline CH-164 & 150 & 4 & 0.065 & & 1.073 \\
\hline CH-165 & 150 & 4 & 0.0593 & & 1.061 \\
\hline CH-166 & 150 & 4 & 0.0403 & & 1.056 \\
\hline CH-167 & 150 & 4 & 0.0507 & & 1.147 \\
\hline CH-168 & 150 & 4 & 0.0359 & & 1.108 \\
\hline CH-169 & 150 & 4 & 0.0663 & & 1.006 \\
\hline CH-170 & 150 & 4 & 0.0449 & & 1.110 \\
\hline CH-187 & 185 & 6 & 0.0587 & & 1.150 \\
\hline CH-188 & 185 & 6 & 0.0405 & & 1.114 \\
\hline CH-189 & 185 & 6 & 0.0286 & & 1.090 \\
\hline CH-190 & 185 & 6 & 0.0379 & & 1.113 \\
\hline CH-191 & 185 & 6 & 0.0603 & & 1.116 \\
\hline CH-192 & 185 & 6 & 0.0596 & & 1.067 \\
\hline CH-193 & 185 & 6 & 0.0358 & & 1.201 \\
\hline CH-194 & 185 & 6 & 0.0185 & & 1.264 \\
\hline CH-155 & 229 & 8 & 0.0598 & & 1.060 \\
\hline CH-156 & 229 & 8 & 0.0279 & & 1.185 \\
\hline CH-157 & 229 & 8 & & & 1.043 \\
\hline CH-158 & 229 & 8 & & & 1.042 \\
\hline CH-159 & 229 & 8 & & & 1.024 \\
\hline CH-160 & 229 & 8 & & & \\
\hline CH-161 & 229 & 8 & & & \\
\hline CH-162 & 229 & 8 & & & \\
\hline & & & & & \\
\hline
\end{tabular}


Table I-2. Mussel Shell A/I Ratios and ASP/GLU Ratios

\begin{tabular}{|c|c|c|c|c|c|}
\hline Lab\# & Lot \# & Zone & A/I Ratio & Aspartic acid/Glutamic acid & Species \\
\hline CH-218 & 78 & 2 & 0.0605 & 1.900 & Tritogonia verrucosa \\
\hline CH-215 & 78 & 2 & 0.0708 & 1.870 & Amblema plicata \\
\hline CH-216 & 78 & 2 & 0.0811 & 1.830 & Amblema plicata \\
\hline CH-217 & 78 & 2 & 0.0920 & 1.820 & Tritogonia verrucosa \\
\hline CH-211 & 78 & 2 & 0.0957 & 1.880 & Amblema plicata \\
\hline CH-212 & 78 & 2 & 0.1040 & 1.750 & Amblema plicata \\
\hline CH-213 & 78 & 2 & 0.1070 & 1.900 & Amblema plicata \\
\hline CH-214 & 78 & 2 & 0.3550 & 1.120 & Amblema plicata \\
\hline CH-183 & 150 & 4 & 0.0487 & 1.180 & Amblema plicata \\
\hline CH-182 & 150 & 4 & 0.0487 & 3.030 & Amblema plicata \\
\hline CH-180 & 150 & 4 & 0.0655 & 1.880 & Amblema plicata \\
\hline CH-185 & 150 & 4 & 0.0666 & 1.990 & Amblema plicata \\
\hline CH-179 & 150 & 4 & 0.0759 & 2.010 & Amblema plicata \\
\hline CH-181 & 150 & 4 & 0.0800 & 1.830 & Amblema plicata \\
\hline CH-184 & 150 & 4 & 0.2240 & 1.320 & Amblema plicata \\
\hline CH-186 & 150 & 4 & 0.2310 & 1.420 & Amblema plicata \\
\hline CH-207 & 185 & 6 & 0.0569 & 2.010 & Amblema plicata \\
\hline CH-208 & 185 & 6 & 0.0762 & 2.160 & Amblema plicata \\
\hline CH-203 & 185 & 6 & 0.0785 & 2.000 & Amblema plicata \\
\hline CH-204 & 185 & 6 & 0.0819 & 2.020 & Amblema plicata \\
\hline CH-206 & 185 & 6 & 0.0886 & 2.190 & Amblema plicata \\
\hline CH-205 & 185 & 6 & 0.0959 & 1.890 & Amblema plicata \\
\hline CH-210 & 185 & 6 & 0.0965 & 2.010 & Tritogonia verrucosa \\
\hline CH-209 & 185 & 6 & 0.9850 & 0.310 & Tritogonia verrucosa \\
\hline CH-175 & 229 & 8 & 0.0557 & 1.250 & Amblema plicata \\
\hline CH-171 & 229 & 8 & 0.0651 & 2.080 & Amblema plicata \\
\hline CH-173 & 229 & 8 & 0.0812 & 1.150 & Amblema plicata \\
\hline CH-176 & 229 & 8 & 0.0943 & 1.000 & Amblema plicata \\
\hline CH-172 & 229 & 8 & 0.1720 & 1.750 & Amblema plicata \\
\hline CH-177 & 229 & 8 & 0.2240 & 1.340 & Amblema plicata \\
\hline CH-174 & 229 & 8 & 0.2960 & 0.640 & Amblema plicata \\
\hline CH-178 & 229 & 8 & 1.0100 & 0.160 & Tritogonia verrucosa \\
\hline
\end{tabular}





\title{
Appendix J
}

\section{Prehistoric Ceramic Sherds from 41MM341}

\author{
Timothy K. Perttula
}




\title{
Appendix J: Prehistoric Ceramic Sherds from 41MM341
}

\author{
Timothy K. Perttula
}

\section{Analysis of the Ceramic Sherds}

Thirteen prehistoric ceramic sherds have been recovered from 41MM341 on the Little River in Milam County, Texas, during recent archeological investigations by the Center for Archaeological Research at The University of Texas at San Antonio. The prehistoric component dates about 1050 BP. The sherds are from $0-30 \mathrm{~cm}$ bs in Block 1, Unit A (n=2), Unit B (n=9), and BHT $24(\mathrm{n}=2)$.

The sherds are from two different vessels. The first vessel ( $\mathrm{n}=11$ sherds, including five sherdlets from Unit $\mathrm{B})$ is represented by all the sherds from Unit A and BHT 24, and seven of the sherds in Unit B; the sherdlets are less than $1 \mathrm{~cm}$ in length and width. This vessel has finely crushed and burned bone temper inclusions, and it has been fired in a reducing or low oxygen environment (cf. Teltser 1993:Figure 2B). The sherd cores are black. The sherds are from the body of a thick-walled vessel, probably a jar; the body wall thickness ranges from 6.9-9.4 $\mathrm{mm}$, with a mean of $8.8 \pm 0.6 \mathrm{~mm}$. Two of the body sherds have a smoothed exterior surface, and one (from BHT 24) has remnants of an organic residue from use of the vessel for cooking foodstuffs

The second vessel includes two sherds from Unit B. The sherds are from a carinated bowl with bone and grog temper, and the clay paste is sandy. The carinated bowl had been fired in a reducing environment, but cooled in a high oxygen environment (cf. Teltser 1993:Figure 2F). Body wall thickness ranges from 7.9-8.4 mm, with a mean of $8.15 \pm 0.25 \mathrm{~mm}$. One of the carinated bowl sherds has a single broad horizontal incised line above the carination, and it is likely the decorative element consists of multiple horizontal lines on the rim of the vessel.

\section{Discussion}

Although the ceramic sherds from 41MM341 are tempered with bone, the limited amount of bone in the paste (less than 10 percent of the paste matrix), the thick body walls (i.e., almost twice as thick as bone-tempered Leon Plain from Central Texas sites), and the absence of well-burnished exterior and/or interior surfaces indicate that the bone-tempered wares from the site are not from post-A.D. 1250 Leon Plain vessels. Whether it is a locallymade vessel is unknown at the present time, although this seems a reasonable conclusion. The occurrence of grog temper in the incised carinated bowl from 41MM341 strongly suggests that this vessel was made in the Caddoan area of northeastern Texas. Grog temper is widely used in Caddoan vessels of all time periods, and the carinated bowl form also appears to be a Caddoan innovation in Texas. To ascertain the manufacturing locale of the two different vessels, I recommend that a sherd from each vessel be analyzed by instrumental neutron activation analysis (INAA) and petrographic analysis. The current INAA and petrographic databases for Caddoan and Central Texas ceramics are sufficiently robust (see Perttula 1999) to be able to determine the likely compositional origin of the two vessels.

Similar bone and/or grog-tempered sherds have been reported from Post Oak Savanna sites in east central Texas, particularly in the Navasota River basin, although prehistoric ceramics are not abundant in contexts dating from 1250-250 вр (Fields 1995:314-318,323-324). At sites in Grimes County, for example, plain and decorated grog and bone-tempered sherds, and plain sherds with bone temper and/or sandy pastes; the decorated sherds have stylistic affiliations with Caddoan wares as well as San Jacinto wares made on the upper Texas coast (Rogers 1995). Turpin and Carpenter (1994:17) recovered thick $(9.0 \mathrm{~mm})$ and undecorated grog-tempered sandy paste 
sherds at 41RT285 on Walnut Creek, near its confluence with the Brazos River, but in a context postdating A.D. 1250. At site 41RT510 in the Navasota River basin (Perttula n.d.), grog, grog-sandy paste, and bone-tempered sherds from plain jars and bowls are relatively abundant $(n=36)$, and the vessels are relatively thick $(6.6-10.5$ $\mathrm{mm})$. Rims are direct with rounded or flattened lips, and the sherds are from vessels primarily reduced during firing (83\%). The few decorated sherds in the 41RT510 collection -horizontal and diagonal incised lines and fingernail punctated elements- suggest that the ceramics from this site date from ca. A.D. 900-1200, roughly contemporaneous with the ceramics from 41MM341.

\section{References Cited}

Fields, R. C.

1995 The Archeology of the Post Oak Savannah of East Central Texas. Bulletin of the Texas Archeological Society 66:301-330.

Perttula, T. K.

1999 Ceramic Evidence for Prehistoric Caddoan Trade and Exchange. Mini-NSF Grant Proposal on file, Research Reactor Center, University of Missouri, Columbia.

n.d. The Ceramic and Lithic Assemblage from a Late Prehistoric Site (41RT510) in the Post Oak Savanna, Robertson County, Texas. MS in preparation.

Rogers, R.

1995 Archeological Excavations at Prehistoric Sites 41GM166, 41GM281, and 41GM282 at the Gibbons Creek Lignite Mine, Grimes County, Texas. Document No. 940611. Espey, Huston \& Associates, Inc., Austin.

Teltser, P. A.

1993 An Analytic Strategy for Studying Assemblage-Scale Ceramic Variation: A Case Study from Southeast Missouri. American Antiquity 58(3):530-543.

Turpin, J., and S. M. Carpenter

1994 Continuing Cultural Resource Management at Calvert Mine: 1993 Prehistoric Site Testing, Robertson County. Technical Series No. 42. Texas Archeological Research Laboratory, The University of Texas at Austin. 
The following information is provided in accordance with the General Rules of Practice and Procedure, Chapter 41.11 (Investigative Reports), Texas Antiquities Committee:

1. Type of investigation: Phase II shovel testing

2. Project name: Little River Testing

3. County: Milam

4. Principal investigator(s): Robert J. Hard and Raymond P. Mauldin

5. Name and location of sponsoring agency: Texas Department of Transportation, Environmental Affairs Division, 125 East 11th Street, Austin, TX 78701-2843.

6. Texas Antiquities Permit No.: 2319

7. Published by the Center for Archaeological Research, The University of Texas at San Antonio, 6900 N. Loop 1604 W., San Antonio, Texas 78249-0658, 2001

A list of publications offered by the Center for Archaeological Research is available. Call (210) 458-4378; write to the Center for Archaeological Research, The University of Texas at San Antonio, 6900 N. Loop 1604 W., San Antonio, Texas 78249-0658; e-mail to car@lonestar.utsa.edu; or visit CAR's web site at http://car.utsa.edu. 